\author{
GÖTTINGER ZENTRUM \\ FÜR BIODIVERSITÄTSFORSCHUNG UND ÖKOLOGIE \\ - GÖTTINGEN CENTRE FOR BIODIVERSITY AND ECOLOGY -
}

\title{
Photosynthetic capacity and nitrogen nutrition of Ecuadorian montane forest trees
}

\author{
Dissertation zur Erlangung des Doktorgrades der \\ Mathematisch-Naturwissenschaftlichen Fakultäten der \\ Georg-August-Universität Göttingen
}

vorgelegt von

Diplom Biologin

Bärbel Wittich

aus

Ulm an der Donau

Göttingen, Februar 2013 
Referentin/Referent: Prof. Dr. Christoph Leuschner

Korreferentin/Korreferent: Prof. Dr. Dirk Hölscher

Tag der mündlichen Prüfung: 09. 04. 2013 


\section{Table of contents}

\section{CHAPTER 1}

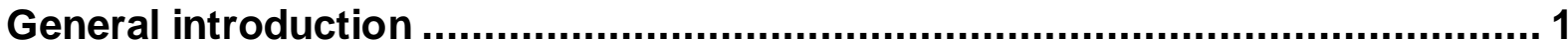

Tropical montane forests and nitrogen limitation along elevational gradients..... 2

The dependence of photosynthetic capacity in tropical forests on altitude and

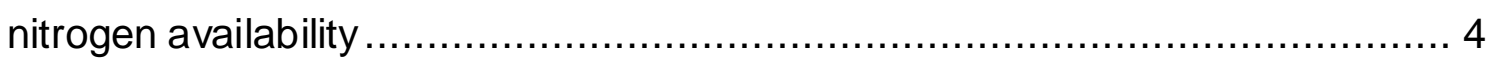

Preference for different nitrogen forms and tropical montane forest trees ......... 4

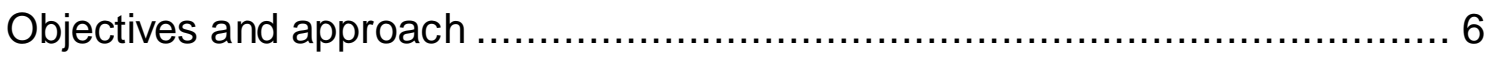

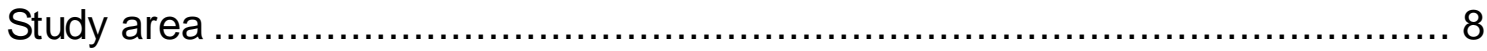

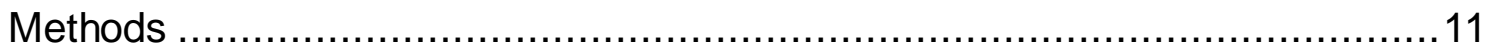

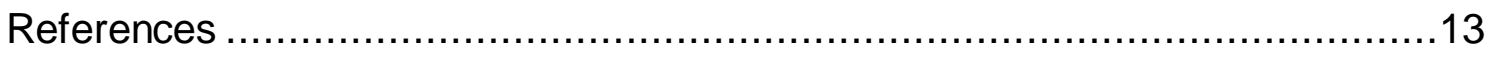

\section{CHAPTER 2}

Altitudinal change in the photosynthetic capacity of tropical trees: A case study from Ecuador and a pantropical literature analysis

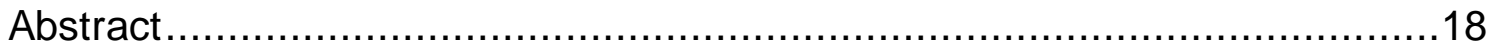

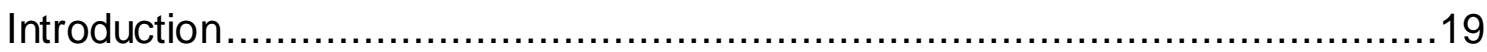

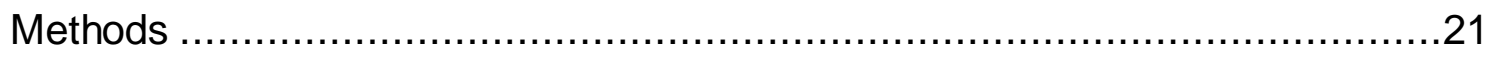

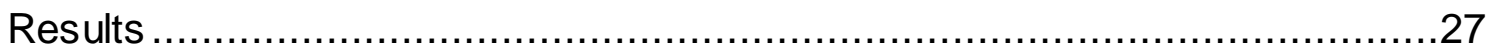

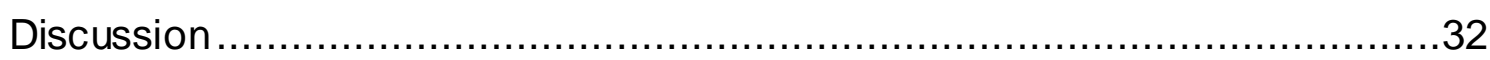

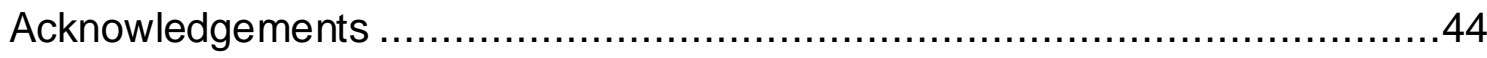

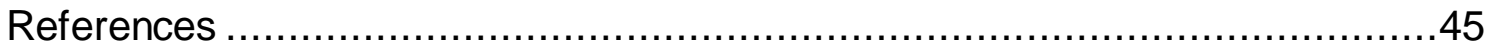

\section{CHAPTER 3}

Environmental and biotic controls of photosynthetic capacity in tropical trees (southern Ecuador): the role of elevation, [CO2], temperature and

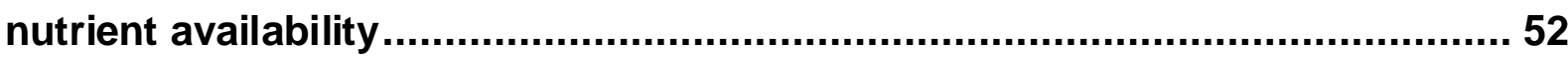

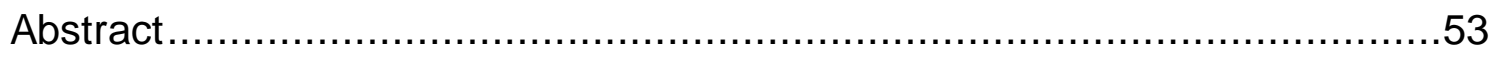

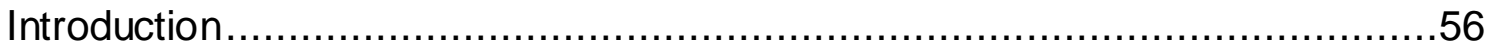

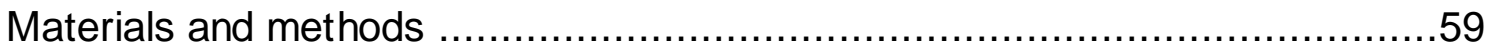

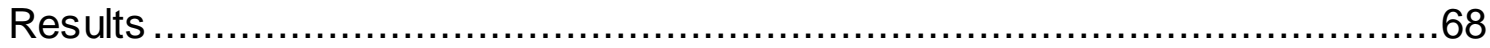

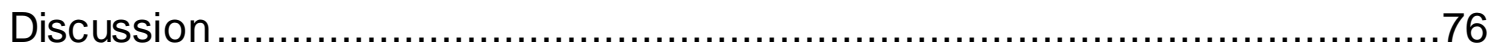

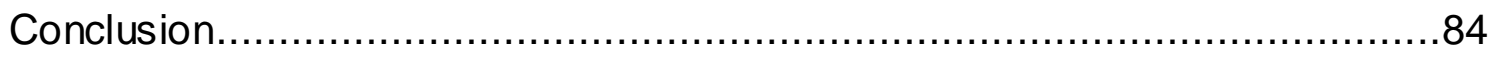

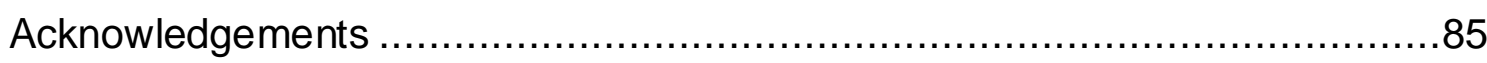


References

CHAPTER 4

Ammonium, nitrate and glycine uptake of six Ecuadorian tropical montane forest tree species: an in situ pot experiment with saplings ....................... 91

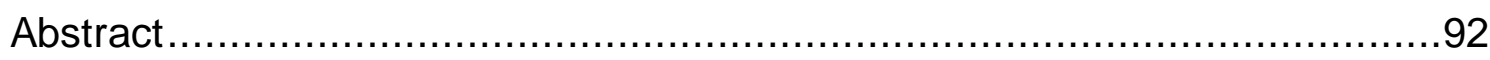

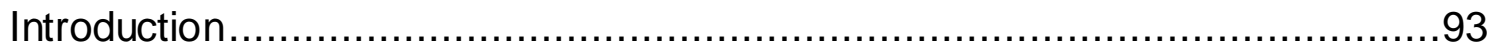

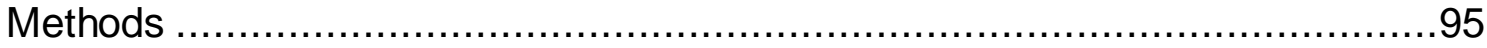

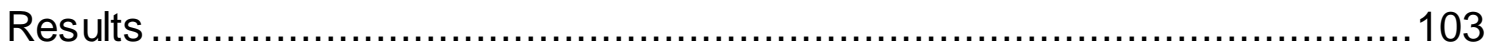

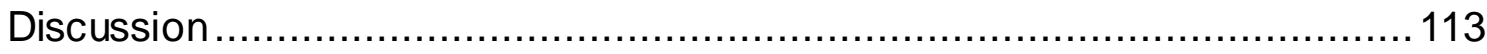

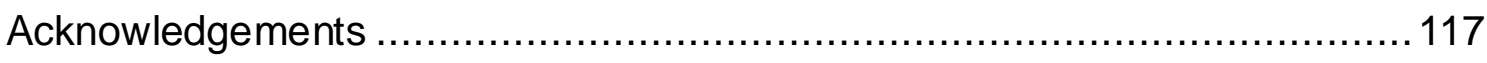

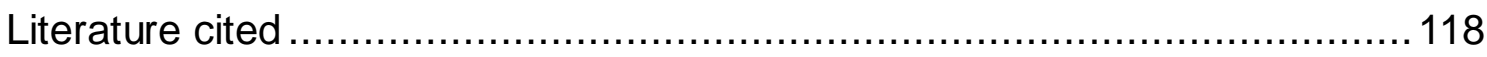

\section{CHAPTER 5}

Synthesis

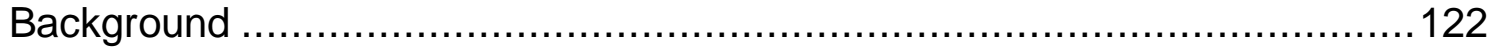

Photosynthetic capacity as affected by altitude .............................. 123

Effect of temperature, partial pressure of $\mathrm{CO}_{2}$ and nutrient availability on

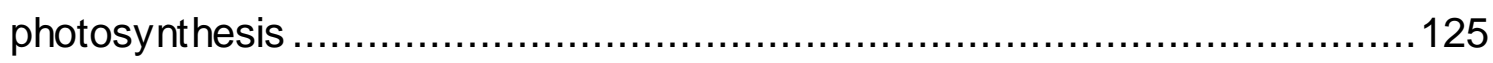

Altitude effects on the preference for different nitrogen forms ..................127

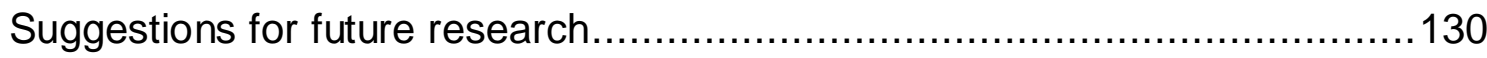

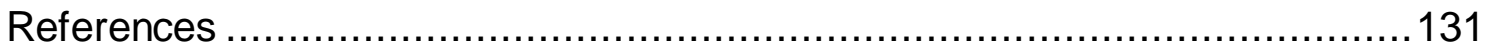

\section{CHAPTER 6}

Summary / Zusammenfassung ...............................................................134

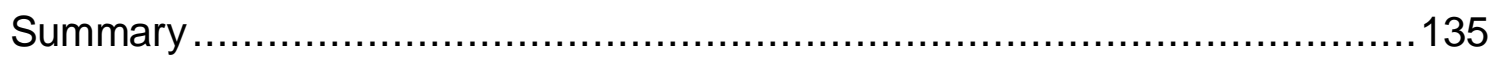

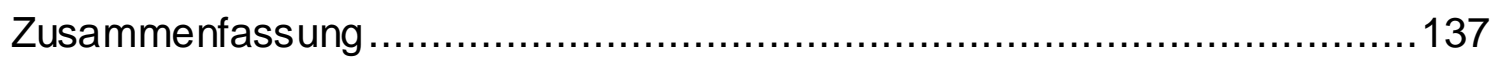

\section{CHAPTER 7}

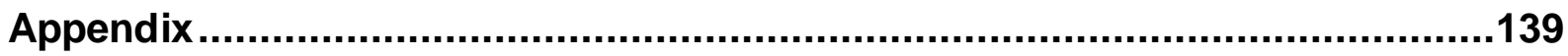

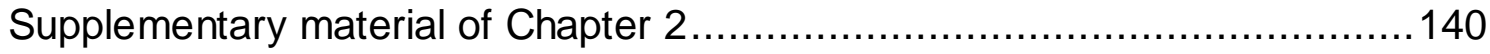

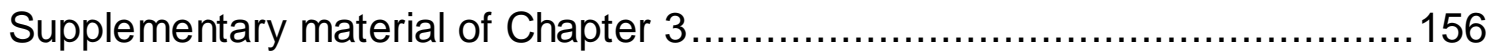

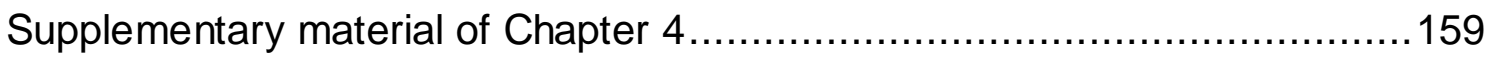

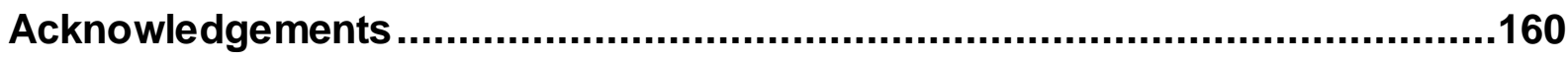

Curriculum Vitae ...................................................................................161 
CHAPTER 1

General introduction 


\section{Tropical montane forests and nitrogen limitation along elevational gradients}

The majority of ecological studies about tropical forests have been conducted in the lowlands even though $12 \%$ (204 million ha) of the tropical forests worldwide are situated in mountainous areas (FAO, 1993). Along mountain slopes, the lowland evergreen rain forest gives way to montane rain forest or montane cloud forest. Different types of tropical montane forests can be distinguished with increasing elevation, from premontane forest at lower elevations to elfin forest at high elevations (Grubb et al., 1963; Homeier et al., 2008; Scatena et al., 2011). The change from lowland to montane forest is related to the range of cloud formation and the average minimum temperature dropping below $18^{\circ} \mathrm{C}$ and is accompanied by the appearance of montane tree species and the disappearance of lowland species (Kitayama, 1992; Scatena et al., 2011). Compared to lowland forests, tropical montane forests have a reduced canopy height, a simpler canopy structure and a higher abundance of epiphytes and mosses (Frahm and Gradstein, 1991; Scatena et al., 2011).

Along elevational gradients, tropical montane forest trees experience modifications in form and function, these are adaptations in leaf morphology and physiology, tree stature, carbon allocation patterns, and productivity (e.g. Cordell et al., 1999; Moser, 2008; Moser et al., 2011, 2007). The most remarkable changes are the decrease in tree size (Aiba and Kitayama, 1999; Raich et al., 1997) and the reduction in aboveground net primary production with increasing altitude (Kitayama and Aiba, 2002; Moser et al., 2011; Raich et al., 1997). A decrease in stature, aboveground biomass, aboveground productivity and number of life forms with elevation has been attributed primarily to the increase in cloudiness and the decrease in temperature (Bruijnzeel and Veneklaas, 1998; Grubb, 1977). Other environmental factors that change with altitude are air pressure and the atmospheric concentrations of $\mathrm{CO}_{2}$ and $\mathrm{O}_{2}$ and UV-B radiation. In tropical montane forests, soil moisture tends to increase with elevation in many cases while the plant availability of nutrients, in particular of nitrogen, tends to decrease with altitude (Benner et al., 2010; Moser, 2008; Soethe et 
al., 2008). Along some mountain slopes, a decrease of foliar nitrogen concentration and an increase in leaf longevity with elevation was found (e.g. Letts and Mulligan, 2005; Moser et al., 2010; Tanner et al., 1998) pointing to a nitrogen limitation of tree growth at high elevations. Leaves that are smaller, thicker and with lower nitrogen content were found to be characteristic for tropical montane forests at high elevation (Grubb, 1977). The structural changes are a consequence of rapid changes in the floristic composition with increasing elevation (Homeier et al., 2008).

Most tropical lowland forests are supposed to be phosphorus limited with nitrogen not being limiting for productivity (Paoli et al., 2005; Tanner et al., 1998). However, in tropical montane forests nitrogen limitation should become more crucial with elevation, mainly, due to reduced decomposition and mineralization rates with decreasing temperatures, increasing soil humidity and decreasing litter quality and, therefore, lower availability of nitrogen for plants at higher altitudes (Jones et al., 2009; Joshi et al., 2003; Marrs et al., 1988; Vitousek and Sanford, 1986). Moreover, reduced decomposition rates at higher altitudes lead to thicker organic soil layers and a change in available nitrogen forms from mostly inorganic at low elevations to mostly organic at high elevations (lost, 2008; Wolf et al., 2011). Aside from phosphorus, nitrogen has been shown to limit productivity in tropical montane forests (Tanner et al., 1998; Vitousek, 1984). The nitrogen limitation of tropical montane forests seems to be linked to soil development (Walker and Syers, 1976). Due to erosion, the soils found in mountainous areas are often relatively young and shallow (Foster, 2001) compared to the highly weathered soils of the tropical lowland forests (McGroddy et al., 2008). With proceeding soil development, soils become poorer in phosphorus, which is almost exclusively provided by the soil parent material and is washed out over time, and richer in nitrogen, which is provided by deposition from the atmosphere and nitrogen fixation and accumulates over time (Hedin et al., 2009; Walker and Syers, 1976). 


\section{The dependence of photosynthetic capacity in tropical forests on altitude and nitrogen availability}

Changes in nitrogen availability along elevational gradients in tropical montane forests should affect the photosynthetic capacity of trees. Maximum rate of photosynthesis $A_{\max }$ is related to foliar nitrogen content mainly because of the high nitrogen demand for the proteins of the Calvin cycle and thylakoids which together represent the majority of foliar nitrogen (Evans, 1989). Therefore, photosynthetic capacity has been found to be closely related to foliar nitrogen (Wright et al., 2004). Other possible factors controlling photosynthetic capacity which change along the altitudinal gradient are the availability of phosphorus, temperature, partial pressure of $\mathrm{CO}_{2}$, VPD and radiation. In contrast to tropical lowland forests, the knowledge about photosynthetic capacity in tropical montane forests is rather scarce. In the rough terrain with often steep slopes, it is difficult to get access to the sun leaves of the canopies. The few studies accomplished in tropical high elevation forests, show slightly reduced leaf level photosynthetic rates when compared to lowland forests (Letts and Mulligan, 2005; Rada et al., 2009; van de Weg et al., 2012).

Knowledge about the photosynthetic capacity of the species composing tropical mountain forest is crucial to understand the functioning of this ecosystem. Information on productivity of tropical forests is needed for the development of realistic global carbon budgets and for projecting how these ecosystems will be affected by climatic and atmospheric changes (Clark et al., 2001).

\section{Preference for different nitrogen forms and tropical montane forest trees}

In tropical montane forests, reduced decomposition rates at higher altitudes lead to thicker organic soil layers and together with reduced mineralization and nitrification rates to a change in available nitrogen forms from mostly inorganic at low elevations 
to mostly organic at high elevations (lost, 2008; Wolf et al., 2011). However, the knowledge about tropical montane tree species' preferences for different nitrogen forms is very limited. Trees of different ecosystems have been shown to take up organic nitrogen (Kahmen et al., 2009; McFarland et al., 2010; Näsholm et al., 2009) but the mycorrhizal status of tropical tree species raises doubts about their possible ability to take up organic nitrogen. While ectomycorrhiza (ECM) are able to mobilize nitrogen from organic matter, AM are more effective in capturing inorganic nitrogen (Chalot and Brun, 1998 but note Hodge et al., 2001; Whiteside et al., 2012). Findings from Kottke et al (2004) at $2000 \mathrm{~m}$ elevation in the study region, indicate that arbuscular mycorrhiza (AM)-forming trees dominate the southern Ecuadorian montane forest.

Even the knowledge about preferences for different nitrogen forms of tropical lowland tree species is rather scarce. In two studies on hemi-epiphytic Clusia species, seedlings were able to take up nitrate, ammonium and glycine and preferred ammonium over the other two nitrogen forms (Arndt et al., 2002; Wanek et al., 2002).

So, to date, it remains an unanswered question, if tropical montane trees are able to take up significant amounts of organic nitrogen and how they adapt to different nitrogen forms being available at different altitudes. 


\section{Objectives and approach}

This thesis is part of the DFG funded Research Unit 816 "Biodiversity and sustainable management of a megadiverse mountain ecosystem in South Ecuador". The study aimed at investigating the photosynthetic capacity and nitrogen nutrition of forest trees in a South Ecuadorian mountain rainforest at three sites at 1000, 2000 and $3000 \mathrm{~m}$ asl.

Major aims of the study were

(1) to asses the photosynthetic capacity of adult tropical trees along the elevational transect and to analyse the possible controlling effects of temperature, partial pressure of $\mathrm{CO}_{2}$ and nutrient availability on photosynthesis (chapter 2 and 3).

(2) to investigate altitudinal changes in the use of nitrate, ammonium or organic nitrogen sources by tropical forest trees by means of a stable isotope tracer study on seedlings in mesocosms in montane forest stands at 1000, 2000 and $3000 \mathrm{~m}$ elevation (chapter 4).

With these objectives, the following hypotheses were tested:

(1) Stand-level averages of mass-based $A_{\text {sat }}$ are decreasing with elevation due to decreases in foliar $\mathrm{N}$ and $\mathrm{P}$.

(2) Area-based $A_{\text {sat }}$ remains unchanged because of the LMA increase with altitude.

(3) Area-based $R_{D}$ does not change with elevation.

(4) Tropical trees at high elevations have higher $\mathrm{N}$ and $\mathrm{P}$ contents per leaf area.

(5) Tropical trees at high elevations possess a higher carboxylation efficiency than 
trees at lower elevation.

(6) Due to these adaptations, the $A_{\max }$ of trees at high elevations responds in a homeostatic manner to the lowered $\mathrm{CO}_{2}$ concentration and reduced temperature, thereby compensating for the less favourable environmental conditions.

(7) The saplings of tropical trees are capable of using organic $\mathrm{N}$ even though they are forming arbuscular mycorrhizas.

(8) With increasing elevation, tree saplings increasingly prefer ammonium and glycine over nitrate due to a lowered nitrification rate and increased humus accumulation.

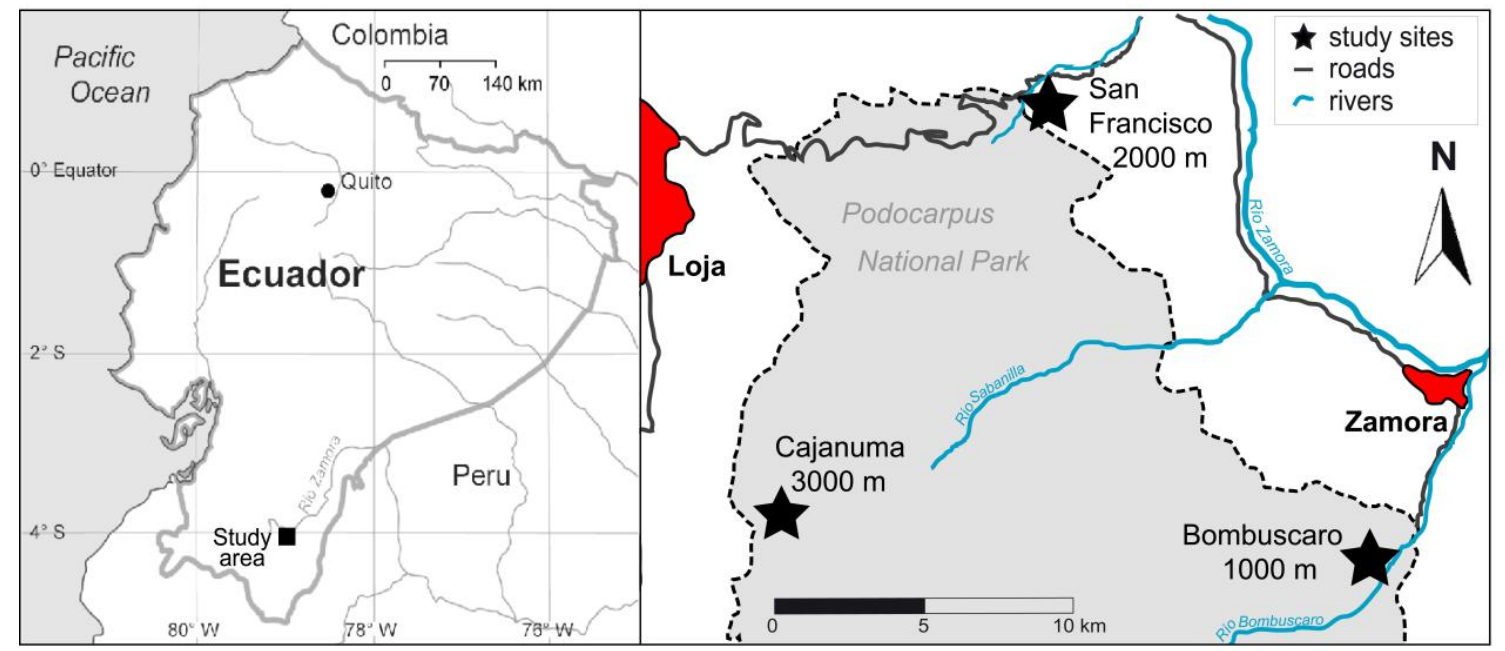

Figure 1. Location of the study area in southern Ecuador with the three stands at 1000, 2000 and 3000 m a.s.l. Figure after Homeier et al. (2012). 


\section{Study area}

Measurements for this thesis were made along an altitudinal gradient in the tropical mountain forest on the eastern slope of the southern Ecuadorian Andes in the provinces of Loja and Zamora-Chinchipe. The study sites were located at 1000, 2000 and $3000 \mathrm{~m}$ a.s.I. inside the Podocarpus National Park and in the Reserva Biológica San Francisco. Maximum distance between the sites was 30 km (Fig. 1).

The study region has a tropical humid climate with an extremely wet season from April to July and a less humid period from September to December. The area is further characterized by high cloudiness and increasing cloud frequency with altitude (Bendix et al., 2006). The MAT along the elevational gradient, studied in this thesis, ranges from $19^{\circ} \mathrm{C}$ at $1000 \mathrm{~m}$ to $9^{\circ} \mathrm{C}$ at $3000 \mathrm{~m}$ a.s.l. (Table 1). The mountain ridge in the study region consists of a variety of acidic bedrocks with granites dominating at $1000 \mathrm{~m}$ and phyllites and sandstones being present at elevations $>1500 \mathrm{~m}$. The soil types change along the slope from Alumic Acrisols at $1000 \mathrm{~m}$ to Gleyic Cambisols $(2000 \mathrm{~m})$ and Podzols $(3000 \mathrm{~m})$ at higher elevation (lost, 2008). The soils are generally acidic and nutrient-poor with increasing humus accumulation with increasing elevation; the organic layer thickness ranges from $48 \mathrm{~mm}$ at $1000 \mathrm{~m}$ to $435 \mathrm{~mm}$ at $3000 \mathrm{~m}$ a.s.l. (Moser et al., 2011; Wolf et al., 2011). While the organic layer thickness increases, the availability of nitrogen in this layer decreases: nitrogen mineralization rate and the amount of KCL-extractable inorganic nitrogen in the organic layers of the study sites are decreasing with altitude, indicating a reduced decomposition at high elevations (Wolf et al., 2011). 
Table 1. Characteristics of the stands (climate data from (Moser et al., 2007; Wolf et al., 2011). Mean annual air temperature and relative air humidity were measured at $1.5 \mathrm{~m}$ height inside the stands at 1050, 1890 and $3060 \mathrm{~m}$. Rainfall data are extrapolated from measurements in a forest gap at approximately $1050 \mathrm{~m}$ (measuring period May 2003 - May 2004), and from measurements in gaps at 1950, and $3170 \mathrm{~m}$ (Emck, 2007). C/N ratio, pH, net nitrification and net $\mathrm{N}$ mineralization rate (in situ buried bag method) refer to the topsoil $(0-10 \mathrm{~cm}$, after (Wolf et al., 2011). For the edaphic parameters, means \pm SE of 4 soil profiles, each dug at lower slope, midslope and ridge position in the stands, are given.

\begin{tabular}{|c|c|c|c|c|}
\hline Elevation & $m$ asl & 1000 & 2000 & 3000 \\
\hline Rainfall & $m m y r^{-1}$ & c. 2230 & c. 1950 & c. 4500 \\
\hline Air temperature & ${ }^{\circ} \mathrm{C}$ & & & \\
\hline Mean & & 19 & 16 & 9 \\
\hline Max & & 30 & 29 & 19 \\
\hline Min & & 12 & 8 & 3 \\
\hline Air humidity & $\%$ & & & \\
\hline Mean & & 86 & 91 & 94 \\
\hline $\operatorname{Max}$ & & 100 & 100 & 100 \\
\hline Min & & 16 & 29 & 29 \\
\hline $\mathrm{pH}\left(\mathrm{H}_{2} \mathrm{O}\right)$ & & $4.9 \pm 0.2$ & $4.4 \pm 0.2$ & $3.9 \pm 0.1$ \\
\hline $\mathrm{C} / \mathrm{N}$ & & $17.6 \pm 0.8$ & $14.8 \pm 0.7$ & $18.2 \pm 0.9$ \\
\hline Net Nitrification & $k g N h a^{-1} 10 d^{-1}$ & $1.97 \pm 0.73$ & $0.89 \pm 0.30$ & $0.01 \pm 0.01$ \\
\hline Net $\mathbf{N}$ mineralization & $k g N h a^{-1} 10 d^{1}$ & $2.5 \pm 0.6$ & $1.5 \pm 0.3$ & $0.1 \pm 0.2$ \\
\hline $\mathrm{KCl}$-extractable $\mathrm{NO}_{3}^{-}$ & $k g N h a^{-1}$ & $0.43 \pm 0.10$ & $0.24 \pm 0.05$ & $0.02 \pm 0.01$ \\
\hline KCl-extractable $\mathrm{NH}_{4}^{+}$ & $k g N h a^{-1}$ & $1.8 \pm 0.3$ & $0.9 \pm 0.1$ & $0.7 \pm 0.1$ \\
\hline
\end{tabular}


The floristic composition of the tropical montane moist forests in the study region was described in detail by Homeier et al. (2008). The three elevations along the gradient correspond to three different forest types:

(1) at $1,000 \mathrm{~m}$ ( $\mathrm{S} 4^{\circ} 7^{\prime} \mathrm{W} 78^{\circ} 58^{\prime}$ ), in the transition zone between tropical lowland and lower montane forest, evergreen premontane forest with tree heights of up to 40 $\mathrm{m}$ is present. Common tree families of this forest type are Fabaceae, Melastomataceae, Moraceae, Myristicaceae, Rubiaceae and Sapotaceae.

(2) The evergreen lower montane forest at $2000 \mathrm{~m}$ ( $\mathrm{S} 3^{\circ} 58^{\prime} \mathrm{W} 79^{\circ} 04^{\prime}$ ) achieves a canopy height of 18 to $22 \mathrm{~m}$. Characteristic tree families are Euphorbiaceae, Lauraceae, Melastomataceae and Rubiaceae.

(3) At $3000 \mathrm{~m}$ ( $\mathrm{S} 4^{\circ} 7^{\prime} \mathrm{W} 79^{\circ} 11^{\prime}$ ), evergreen upper montane forests and elfin-forests are found that extend up to the tree line; canopy height does rarely exceed 8-10 m. Dominant tree families are Aquifoliaceae, Clusiaceae, Cunionaceae, Lauraceae and Melastomataceae.

Stand structural characteristics of the three stands are summarized in Table 2. All three stands are located in protected forest sections. Natural disturbances in the past may have included landslides in the steeply sloped terrain. 
Table 2. Stand structural characteristics of the three stands at 1000,2000 and $3000 \mathrm{~m}$ (Homeier et al., unpublished; Leaf life span and BGB: Moser et al., 2011, 2007). Abbreviations: AGB, aboveground biomass; BGB, belowground biomass (coarse and fine roots); $\mathrm{DBH}$, diameter in breast height; LAl, leaf area index. Given are means \pm SE for each elevation. Means of tree DBH, stem density, basal area and AGB were calculated for 9-18 permanent plots (400 $\mathrm{m}^{2}$ each) covering the whole range of topographic positions at the respective elevations (trees $>10 \mathrm{~cm} \mathrm{DBH}$ ). Estimates for nutrient pools in canopy leaf biomass were calculated from leaf biomass data (Moser et al., 2007) and mean foliar $\mathrm{N}$ and $\mathrm{P}$ concentrations according to Homeier et al. (unpublished). Different small letters indicate significant differences between elevations.

\begin{tabular}{|c|c|c|c|c|c|c|c|}
\hline Elevation & $m$ asl & 1000 & & 2000 & & 3000 & \\
\hline Canopy height & $m$ & $25-30$ & & $16-20$ & & $8-10$ & \\
\hline DBH & $\mathrm{cm}$ & $19 \pm 1$ & $\mathbf{a}$ & $20 \pm 1$ & $\mathbf{a}$ & $18 \pm 1$ & a \\
\hline Stem density & $n h a^{-1}$ & $822 \pm 50$ & $\mathbf{a}$ & $900 \pm 62$ & $\mathbf{a}$ & $1061 \pm 84$ & a \\
\hline Basal area & $m^{2} h a^{-1}$ & $29 \pm 4$ & $\mathbf{a}$ & $34 \pm 3$ & $\mathbf{a}$ & $30 \pm 3$ & a \\
\hline AGB & $M g h a^{-1}$ & $177 \pm 28$ & $\mathbf{a}$ & $158 \pm 22$ & $\mathbf{a}$ & $89 \pm 10$ & b \\
\hline BGB & $M g h a^{-1}$ & 32.1 & & 26.1 & & 62.8 & \\
\hline LAl & $m^{2} m^{-2}$ & $6 \pm 0.4$ & $\mathbf{a}$ & $5.7 \pm 0.5$ & $\mathbf{a}$ & $2.2 \pm 0.2$ & b \\
\hline Leaf life span & months & $16 \pm 2.6$ & $\mathbf{a}$ & $24 \pm 2.3$ & b & $25 \pm 2.3$ & b \\
\hline Leaf biomass & $M g h a^{-1}$ & 6.8 & $\mathbf{a}$ & 9.7 & b & 3.6 & c \\
\hline Leaf biomass $\mathrm{N}$ pool & $k g h a^{-1}$ & 123 & & 202 & & 46 & \\
\hline Leaf biomass $\mathrm{P}$ pool & $\mathrm{kg} \mathrm{ha}^{-1}$ & 3.8 & & 7.9 & & 1.6 & \\
\hline
\end{tabular}

\section{Methods}

Leaf gas exchange was measured between February and May 2009 on each three replicate leaves of the 41 trees (40 species; 123 leaves in total) using a portable IRGA system (LI-6400, LI-COR Biosciences, Lincoln, NE, USA) equipped with a LED $\mathrm{red} / \mathrm{blue}$ light source (type 6400-02B). All measurements were carried out on sunny or over-cast days between 10:00 a.m. and 4:00 p.m. on intact fully expanded leaves of most distal insertion. The branches were part of the lateral canopy with exposure to full sunlight. For every leaf, a light and $\mathrm{COO}_{2}$ response curve was recorded. The temperature simulated in the cuvette was set to the air temperature found to be typical for the measurement time at the respective study site. The water vapour 
saturation deficit in the cuvette was held constant at the respective ambient conditions of the three sites. The photosynthetic light response was determined at photon flux densities of 1500,1000,500, 200, 100,50, 20 and $0 \mu \mathrm{mol} \mathrm{m} \mathrm{m}^{-1}$ starting at highest irradiance. In this measuring task, the $\mathrm{CO}_{2}$ /air mixing ratio was held constant at $370 \mathrm{ppm}$. The photosynthetic $\mathrm{CO}_{2}$ response was measured under light saturation $\left(1500 \mu \mathrm{mol}\right.$ photons $\left.\mathrm{m}^{-2} \mathrm{~s}^{-1}\right)$ at $\mathrm{CO}_{2}$ mixing ratios of $2000,1300,700,360$, 200, 100, 50 and 0 ppm starting at the highest ratio. The $\mathrm{CO}_{2}$ release recorded in the dark at the end of the $\mathrm{CO}_{2}$ response curve was assumed to give an estimate of leaf dark respiration $\left(R_{D}\right)$. Prior to respiration measurement, the leaves were allowed to acclimate for 2-5 min to the dark in the cuvette.

A tracer experiment using the stable isotopes ${ }^{15} \mathrm{~N}$ and ${ }^{13} \mathrm{C}$ was conducted with six tree species (each two per site) that were considered to be representative for the sites according to their relatively high local abundance: Pouteria torta (Mart.) Radlk. (Sapotaceae) and Hedyosmum sprucei Solms (Chloranthaceae, 1000 m asl.), Myrcia sp. nov (undescribed species, Myrtaceae) and Hedyosmum translucidum Cuatrec. (Chloranthaceae, 2000 m), Graffenrieda harlingii Wurdack (Melastomataceae), and Hedyosmum purpurascens Todzia (Chloranthaceae, $3000 \mathrm{~m}$ ). Four to six months before the start of the experiment, saplings of all species were collected from the three stands and planted into plastic pots.

The cultivation pots of $25 \mathrm{~cm}$ diameter and $25 \mathrm{~cm}$ height were filled with local forest soil of the sites where the saplings had been collected. We used soil from $10-30 \mathrm{~cm}$ mineral soil depth in patches of undisturbed primary forest. The pots with each one sapling growing in it were placed on wooden tables at the three study sites in the interior of the local stands under a closed forest canopy.

For every tree species, four treatments with three- to fivefold replication were established: (1) control, (2) addition of labelled nitrate $\left(\mathrm{NH}_{4}{ }^{15} \mathrm{NO}_{3}, 98\right.$ atom-\%), (3) addition of labelled ammonium $\left({ }^{15} \mathrm{NH}_{4} \mathrm{NO}_{3} ; 98\right.$ atom-\%), and (4) addition of ${ }^{15} \mathrm{~N}{ }^{13} \mathrm{C}$ double-labelled glycine $\left(\mathrm{H}_{2}{ }^{15} \mathrm{~N}^{13} \mathrm{CH}_{2}{ }^{13} \mathrm{CO}_{2} \mathrm{H} ; 98\right.$ atom-\%). 
All investigated plants were harvested either five days after nutrient application (four species), or two, five and eight days after application (two species) to document the temporal course of ${ }^{15} \mathrm{~N}$ acquisition in plant biomass.

\section{References}

Aiba, S., Kitayama, K., 1999. Structure, composition and species diversity in an altitude-substrate matrix of rain forest tree communities on Mount Kinabalu, Borneo. Plant Ecology 140, 139-157.

Arndt, S.K., Wanek, W., Hoch, G., Richter, A., Popp, M., 2002. Flexibility of nitrogen metabolism in the tropical C3-crassulacean acid metabolism tree species Clusia minor. Functional Plant Biology 29, 741-747.

Bendix, J., Homeier, J., Cueva Ortiz, E., Emck, P., Breckle, S.-W., Richter, M., Beck, E., 2006. Seasonality of weather and tree phenology in a tropical evergreen mountain rain forest. Int $\mathrm{J}$ Biometeorol 50, 370-384.

Benner, J., Vitousek, P.M., Ostertag, R., 2010. Nutrient cycling and nutrient limitation in tropical montane cloud forests, in: Bruijnzeel, L.A., Scatena, F.N., Hamilton, L.S. (Eds.), Tropical Montane Cloud Forests, International Hydrology Series. Cambridge University Press, Cambridge, UK, pp. 90-100.

Bruijnzeel, L.A., Veneklaas, E.J., 1998. Climatic conditions and tropical montane forest productivity: the fog has not lifted yet. Ecology 79, 3-9.

Chalot, M., Brun, A., 1998. Physiology of organic nitrogen acquisition by ectomycorrhizal fungi and ectomycorrhizas. FEMS Microbiology Reviews 22, 21-44.

Clark, D.A., Brown, S., Kicklighter, D.W., Chambers, J.Q., Thomlinson, J.R., Ni, J., Holland, E.A., 2001. Net primary production in tropical forests: an evaluation and synthesis of existing field data. Ecological Society of America 11, 371384.

Cordell, S., Goldstein, G., Meinzer, F.C., Handley, L.L., 1999. Allocation of nitrogen and carbon in leaves of Metrosideros polymorpha regulates carboxylation capacity and delta ${ }^{13} \mathrm{C}$ along an altitudinal gradient. Functional Ecology 13, 811-818.

Emck, P., 2007. A climatology of South Ecuador. With special focus on the major Andean ridge as Atlantic-Pacific climate divide. Dissertation, Universität Erlangen-Nürnberg.

Evans, J.R., 1989. Photosynthesis and nitrogen relationships in leaves of C 3 plants. 
Oecologia 78, 9-19.

FAO, 1993. Forest resources assessment 1990. Tropical countries. FAO forestry paper 112.

Foster, P., 2001. The potential negative impacts of global climate change on tropical montane cloud forests. Earth-Science Reviews 55, 73-106.

Frahm, J.-P., Gradstein, S.R., 1991. An Altitudinal Zonation of Tropical Rain Forests Using Byrophytes. Journal of Biogeography 18, 669.

Grubb, P.J., 1977. Control of forest growth and distribution on wet tropical mountains: with special reference to mineral nutrition. Annual Review of Ecology and Systematics 8, 83-107.

Grubb, P.J., Lloyd, J.R., Pennington, T.D., Whitmore, T.C., 1963. A Comparison of Montane and Lowland Rain Forest in Ecuador I. The Forest Structure, Physiognomy, and Floristics. The Journal of Ecology 51, 567.

Hedin, L.O., Brookshire, E.N.J., Menge, D.N.L., Barron, A.R., 2009. The Nitrogen Paradox in Tropical Forest Ecosystems. Annual Review of Ecology, Evolution, and Systematics 40, 613-635.

Hodge, A.C., Campbell, C.D., Fitter, A.H., 2001. An arbuscular mycorrhizal fungus accelerates decomposition and acquires nitrogen directly from organic material. Nature 413, 297-299.

Homeier, J., Hertel, D., Camenzind, T., Cumbicus, N.L., Maraun, M., Martinson, G.O., Poma, N., Rillig, M.C., Sandmann, D., Scheu, S., Veldkamp, E., Wilke, W., Wullaert, H., Leuschner, C., 2012. Tropical andean forests are highly susceptible to Nutrient Inputs—rapid effects of experimental $\mathrm{N}$ and $\mathrm{P}$ addition to an ecuadorian montane forest. PLoS ONE 7, e47128.

Homeier, J., Werner, F.A., Gradstein, S.R., Breckle, S.-W., Richter, M., 2008. Potential vegetation and floristic composition of Andean forests in South Ecuador, with a focus on the RBSF, in: Beck, E., Bendix, J., Kottge, I., Makeschin, F., Mosandl, R. (Eds.), Gradients in a Tropical Mountain Ecosystem of Ecuador, Ecological Studies. Springer-Verlag, Berlin Heidelberg, pp. 87-100.

lost, S., 2008. Soil respiration, microbial respiration and mineralization in soils of montane rainforests of Southern Ecuador: influence of altitude. PhD thesis, Technical University of Dresden.

Jones, D.L., Kielland, K., Sinclair, F.L., Dahlgren, R.A., Newsham, K.K., Farrar, J.F., Murphy, D.V., 2009. Soil organic nitrogen mineralization across a global latitudinal gradient. Global Biogeochemical Cycles 23.

Joshi, A.B., Vann, D.R., Johnson, A.H., Miller, E.K., 2003. Nitrogen availability and forest productivity along a climosequence on Whiteface Mountain, New York. 
Canadian Journal of Forest Research 33, 1880-1891.

Kahmen, A., Livesley, S.J., Arndt, S.K., 2009. High potential, but low actual, glycine uptake of dominant plant species in three Australian land-use types with intermediate $\mathrm{N}$ availability. Plant and Soil 325, 109-121.

Kitayama, K., 1992. An altitudinal transect study of the vegetation on Mount Kinabalu, Borneo. Plant Ecology 102, 149-171.

Kitayama, K., Aiba, S.-I., 2002. Ecosystem structure and productivity of tropical rain forests along altitudinal gradients with contrasting soil phosphorus pools on Mount Kinabalu, Borneo. Journal of Ecology 90, 37-51.

Kottke, I., Beck, A., Oberwinkler, F., Homeier, J., Neill, D., 2004. Arbuscular endomycorrhizas are dominant in the organic soil of a neotropical montane cloud forest. Journal of Tropical Ecology 20, 125-129.

Letts, M.G., Mulligan, M., 2005. The impact of light quality and leaf wetness on photosynthesis in north-west Andean tropical montane cloud forest. J. Trop. Ecol. 21, 549-557.

Marrs, R.H., Proctor, J., Heaney, A., Mountford, M.D., 1988. Changes in soil nitrogenmineralization and nitrification along an altitudinal transect in tropical rain forest in Costa Rica. Journal of Ecology 76, 466-482.

McFarland, J.W., Ruess, R.W., Kielland, K., Pregitzer, K., Hendrick, R., Allen, M., 2010. Cross-ecosystem comparisons of in situ plant uptake of amino acid-N and $\mathrm{NH} 4+$. Ecosystems 13, 177-193.

McGroddy, M.E., Silver, W.L., De Oliveira, R.C., De Mello, W.Z., Keller, M., 2008. Retention of phosphorus in highly weathered soils under a lowland Amazonian forest ecosystem. Journal of Geophysical Research 113.

Moser, G., 2008. Elevation effects on key processes of carbon cycling in South Ecuadorian mountain forests. PhD Thesis. University of Göttingen, Germany.

Moser, G., Hertel, D., Leuschner, C., 2007. Altitudinal change in LAl and stand leaf biomass in tropical montane forests: a transect study in Ecuador and a pantropical meta-analysis. Ecosystems 10, 924-935.

Moser, G., Leuschner, C., Hertel, D., Graefe, S., Soethe, N., lost, S., 2011. Elevation effects on the carbon budget of tropical mountain forests (S Ecuador): the role of the belowground compartment. Global Change Biology 17, 2211-2226.

Moser, G., Leuschner, C., Röderstein, M., Graefe, S., Soethe, N., Hertel, D., 2010. Biomass and productivity of fine and coarse roots in five tropical mountain forests stands along an altitudinal transect in southern Ecuador. Plant Ecology \& Diversity 3, 151-164.

Näsholm, T., Kielland, K., Ganeteg, U., 2009. Uptake of organic nitrogen by plants. New Phytologist 182, 31-48. 
Paoli, G.D., Curran, L.M., Zak, D.R., 2005. Phosphorus efficiency of Bornean rain forest productivity: Evidence against the unimodal efficiency hypothesis. Ecology 86, 1548-1561.

Rada, F., García-Núnez, C., Ataroff, M., 2009. Leaf gas exchange in canopy species of a Venezuelan cloud forest. Biotropica 41, 659-664.

Raich, J.W., Russell, A.E., Vitousek, P.M., 1997. Primary productivity and ecosystem development along an elevational gradient on Mauna Loa, Hawaii. Ecology 78, 707-721.

Scatena, F.N., Bruijnzeel, L.A., Bubb, P., Das, S., 2011. Setting the stage. Tropical Montane Cloud Forests: Science for Conservation and Management 1.

Soethe, N., Lehmann, J., Engels, C., 2008. Nutrient availability at different altitudes in a tropical montane forest in Ecuador. Journal of Tropical Ecology 24.

Tanner, E.V.J., Vitousek, P.M., Cuevas, E., 1998. Experimental investigation of nutrient limitation of forest growth on wet tropical mountains. Ecology 79, 1022.

Van de Weg, M.J., Meir, P., Grace, J., Ramos, G.D., 2012. Photosynthetic parameters, dark respiration and leaf traits in the canopy of a Peruvian tropical montane cloud forest. Oecologia 168, 23-34.

Vitousek, P.M., 1984. Litterfall, Nutrient Cycling, and Nutrient Limitation in Tropical Forests. Ecology 65, 285-298.

Vitousek, P.M., Sanford, R.L., 1986. Nutrient cycling in moist tropical forest. Annu. Rev. Ecol. Syst. 17, 137-167.

Walker, T.W., Syers, J.K., 1976. The fate of phosphorus during pedogenesis. Geoderma 15, 1-19.

Wanek, W., Arndt, S.K., Huber, W., Popp, M., 2002. Nitrogen nutrition during ontogeny of hemiepiphytic Clusia species. Functional Plant Biology 29, 733740.

Whiteside, M.D., Garcia, M.O., Treseder, K.K., 2012. Amino acid uptake in arbuscular mycorrhizal plants. PLoS ONE 7, e47643.

Wolf, K., Veldkamp, E., Homeier, J., Martinson, G.O., 2011. Nitrogen availability links forest productivity, soil nitrous oxide and nitric oxide fluxes of a tropical montane forest in southern Ecuador. Global Biogeochemical Cycles 25.

Wright, I.J., Reich, P.B., Westoby, M., Ackerly, D.D., Baruch, Z., Bongers, F., Cavender-Bares, J., Chapin, T., Cornelissen, J.H.., Diemer, M., others, 2004. The worldwide leaf economics spectrum. Nature 428, 821-827. 


\section{CHAPTER 2}

\section{Altitudinal change in the photosynthetic capacity of tropical trees: A case study from Ecuador and a pantropical literature analysis}

Bärbel Wittich, Viviana Horna, Jürgen Homeier and Christoph Leuschner

2012

Ecosystems 15: 958-973

DOI: $10.1007 / \mathrm{s} 10021-012-9556-9$ 


\section{Abstract}

In tropical mountains, trees are the dominant life form from sea level to more than $4000 \mathrm{~m}$ altitude under highly variable thermal conditions (range of mean annual temperatures: $<8$ to $>28^{\circ} \mathrm{C}$ ). How light-saturated net photosynthesis of tropical trees adapts to variation in temperature, atmospheric $\mathrm{CO}_{2}$ concentration and further environmental factors, that change along elevation gradients, is not precisely known. With gas exchange measurements in mature trees, we determined light-saturated net photosynthesis at ambient temperature $(\mathrm{T})$ and $\left[\mathrm{CO}_{2}\right]\left(\mathrm{A}_{\mathrm{sat}}\right)$ of 40 tree species from 21 families in tropical mountain forests at 1000, 2000 and $3000 \mathrm{~m}$ elevation in southern Ecuador. We tested the hypothesis that stand-level averages of $A_{\text {sat }}$ and leaf dark respiration $\left(R_{D}\right)$ per leaf area remain constant with elevation. Stand-level means of $A_{\text {sat }}$ were 8.8, 11.3 and $7.2 \mu \mathrm{mol} \mathrm{CO}_{2} \mathrm{~m}^{-2} \mathrm{~s}^{-1}$; those of $\mathrm{R}_{\mathrm{D}}$ 0.8, 0.6 and $0.7 \mu \mathrm{mol}$ $\mathrm{CO}_{2} \mathrm{~m}^{-2} \mathrm{~s}^{-1}$ at 1000, 2000 and $3000 \mathrm{~m}$ elevation, respectively, with no significant altitudinal trend. We obtained coefficients of among-species variation in $A_{s a t}$ and $R_{D}$ of $20-53 \%$ ( $n=10-16$ tree species per stand). Examining our data in the context of a pan-tropical $A_{\text {sat }}$ data base for mature tropical trees (c. 170 species from 18 sites at variable elevation) revealed that area-based $A_{\text {sat }}$ decreases in tropical mountains by, on average, $1.3 \mu \mathrm{mol} \mathrm{CO} \mathrm{CO}^{-2} \mathrm{~s}^{-1}$ per $\mathrm{km}$ altitude increase (or by $0.2 \mu \mathrm{mol} \mathrm{CO}_{2} \mathrm{~m}^{-2} \mathrm{~s}^{-1}$ per $\mathrm{K}$ temperature decrease). The $\mathrm{A}_{\text {sat }}$ decrease occurred despite an increase in leaf mass per area with altitude. Local geological and soil fertility conditions and related foliar $\mathrm{N}$ and $\mathrm{P}$ concentrations considerably influenced the altitudinal $\mathrm{A}_{\text {sat }}$ patterns. We conclude that elevation is an important influencing factor of the photosynthetic activity of tropical trees. Lowered $A_{\text {sat }}$ together with a reduced stand leaf area decrease canopy $\mathrm{C}$ gain with elevation in tropical mountains.

Key words: altitudinal gradient, foliar N, foliar $\mathrm{P}$, leaf dark respiration, light-saturated net photosynthesis, tropical lowland forests, mature trees, C source limitation, tropical montane forests 


\section{Introduction}

With an estimated total of 37,000 woody plants (Odegaard 2000), tropical forests possess not only by far more tree species, but also exist under a broader spectrum of environmental conditions, than any other biome on earth. Moist forests once stretched from sea level to the alpine tree line at 3500 to $4800 \mathrm{~m}$ a.s.l., forming closed stands under a very broad range of mean annual temperatures (MAT; $>28$ to $<8{ }^{\circ} \mathrm{C}$ ), rainfall totals (from c. 2000 to $>8000 \mathrm{~mm} \mathrm{yr}^{-1}$ ) and soil fertility conditions (very low to high fertility; Whitmore 1998, Ghazoul and Sheil 2010). As a consequence, tropical forests exhibit large changes in structure, physiognomy and species composition as one ascends from the lowlands to high elevation. Tropical mountain forests (TMFs) replace lowland forests at $\sim 1000 \mathrm{~m}$ elevation, where the climate becomes cooler and often moister, and radiation is frequently reduced due to cloudiness (Hamilton and others 1995, Bruijnzeel and others 2010). Other influential environmental factors that change with altitude are air pressure and the atmospheric concentrations of $\mathrm{CO}_{2}$ and $\mathrm{O}_{2}$, and UV-B radiation. In many altitudinal transects in tropical mountains, soil moisture tends to increase and the plant availability of nutrients, in particular of nitrogen and phosphorus, to decrease with altitude (Soethe and others 2008, Benner and others 2010, Bruijnzeel and others 2010, Moser and others 2008).

Tropical trees seem to respond to altitudinal gradients by modifications in plant form and function, notably adaptation in leaf morphology and physiology, tree stature, carbon allocation patterns and productivity (e.g. Cordell and others 1999; Moser and others 2007, 2008, 2011) but the within-species variation in morphological and functional traits in response to increasing elevation is not well studied. More information exists about community level changes in tree stature, leaf form and function and forest productivity along elevation transects in tropical mountains which result from species turnover along the slope. One of the most obvious changes is the reduction in tree size (Liebermann and others 1996; Raich and others 1997; Aiba and Kitayama 1999; Pollmann and Hildebrand 2005; Shi and others 2008), which is accompanied by a reduction in aboveground NPP from tropical lowland to upper 
montane forests (Hawaii: Raich and others 1997; Sabah, Malaysia: Kitayama and Aiba 2002; Puerto Rico: Weaver and Murphy 1990, Wang and others 2003; Peru: Girardin and others 2010; Ecuador: Moser and others 2011, Leuschner et al., in press). One of the possible underlying causes is the temperature decrease, but $\mathrm{N}$ limitation of tree growth may also be involved in certain mountains where a decrease of foliar $\mathrm{N}$ concentration and an increase in leaf longevity with elevation was found (e.g. Tanner and others 1998; Letts and Mulligan 2005, Moser and others 2010). Grubb and Tanner (1976) and Grubb (1977) identified smaller and thicker leaves with lower $\mathrm{N}$ concentrations as being characteristic for the trees at high elevations in tropical mountains.

Leaf level photosynthesis, the process that defines canopy carbon gain, has only rarely been investigated in TMFs (e.g. Hikosaka et al. 2002, Rada and others 2009, van de Weg and others 2012). In general, we know more about the photosynthetic activity of trees at the alpine tree line and their carbon relations than about altitudinal change in tree photosynthetic capacity in mountain forests, both in tropical and temperate regions (e.g. Rada and others. 1996, Hoch and others 2002; Körner 2003; Smith and others 2009). However, examining how light-saturated net photosynthesis $\left(A_{\text {sat }}\right)$ and canopy $C$ gain change along mountain slopes from lowland to upper montane elevation is crucial for a better understanding of the long-term tree adaptation of trees to changes in temperature, atmospheric $\mathrm{CO}_{2}$ concentration and other abiotic factors, and it may also help to answer to the question about the causes of tropical alpine tree lines.

Altitudinal change in $A_{\text {sat }}$ has been investigated in a few temperate and subtropical mountains (e.g. Benecke and others 1981; Zhang and others 2005; Premoli and Brewer 2007; Wieser and Tausz 2007; Bresson and others 2009) showing either no change (Benecke and others 1981; Wieser and Tausz 2007; Bresson and others 2009; Wieser and others 2010), an increase (Premoli and Brewer 2007), or a decrease with increasing altitude (Slayter and Morrow 1977; Zhang and others 2005). Thus, no consistent pattern has yet been detected. Even less is known about altitudinal change in the $A_{\text {sat }}$ of tropical trees. A notable exception is the altitudinal 20 
transect study in Metrosideros polymorpha in the tropical island forests of Hawaii between 100 and 2500 m a.s.I. (Cordell and others 1998, 1999).

In this transect study in southern Ecuadorian TMFs, we examined patterns of altitudinal variation in light-saturated net photosynthesis $\left(A_{s a t}\right)$ of mature (or premature) trees along a transect from 1000 to $3000 \mathrm{~m}$ a.s.l. covering a large number of tree species (40). We further explored the possible dependence of $A_{\text {sat }}$ on foliar nutrient concentration and leaf morphology along the elevation gradient. Complementary to this field study, we conducted a pan-tropical literature survey of published photosynthesis data from mature tropical trees at contrasting elevation (lowland to upper montane; 12 studies from 18 sites covering almost 170 tree species, excluding seedling and sapling studies). The main objectives of the study were (i) to clarify the position of tropical montane forest trees relative to tropical lowland, subtropical and temperate trees in terms of leaf form and function, and (ii) to search for a significant temperature and altitude dependence of $A_{\text {sat }}$ and $R_{D}$ in tropical trees. We tested the hypotheses that (1) stand-level averages of mass-based $A_{\text {sat }}$ are decreasing with elevation due to decreases in foliar $\mathrm{N}$ and $\mathrm{P}$, while (2) area-based $A_{\text {sat }}$ remains unchanged because of the LMA increase with altitude. We also hypothesized that (3) area-based $R_{D}$ does not change with elevation.

\section{Methods}

\section{Study sites and selection of trees}

The measurements were conducted along a 2000-m elevation transect in tropical mountain forests on the eastern slope of the southern Ecuadorian Andes between February and May 2009. The study sites were located at ca. 1000, 2000 and $3000 \mathrm{~m}$ a.s.I. in the Podocarpus National Park and the Reserva Biológica San Francisco in the Provinces of Loja and Zamora-Chinchipe. The maximum distance between the sites was $30 \mathrm{~km}$ (Figure 1). 


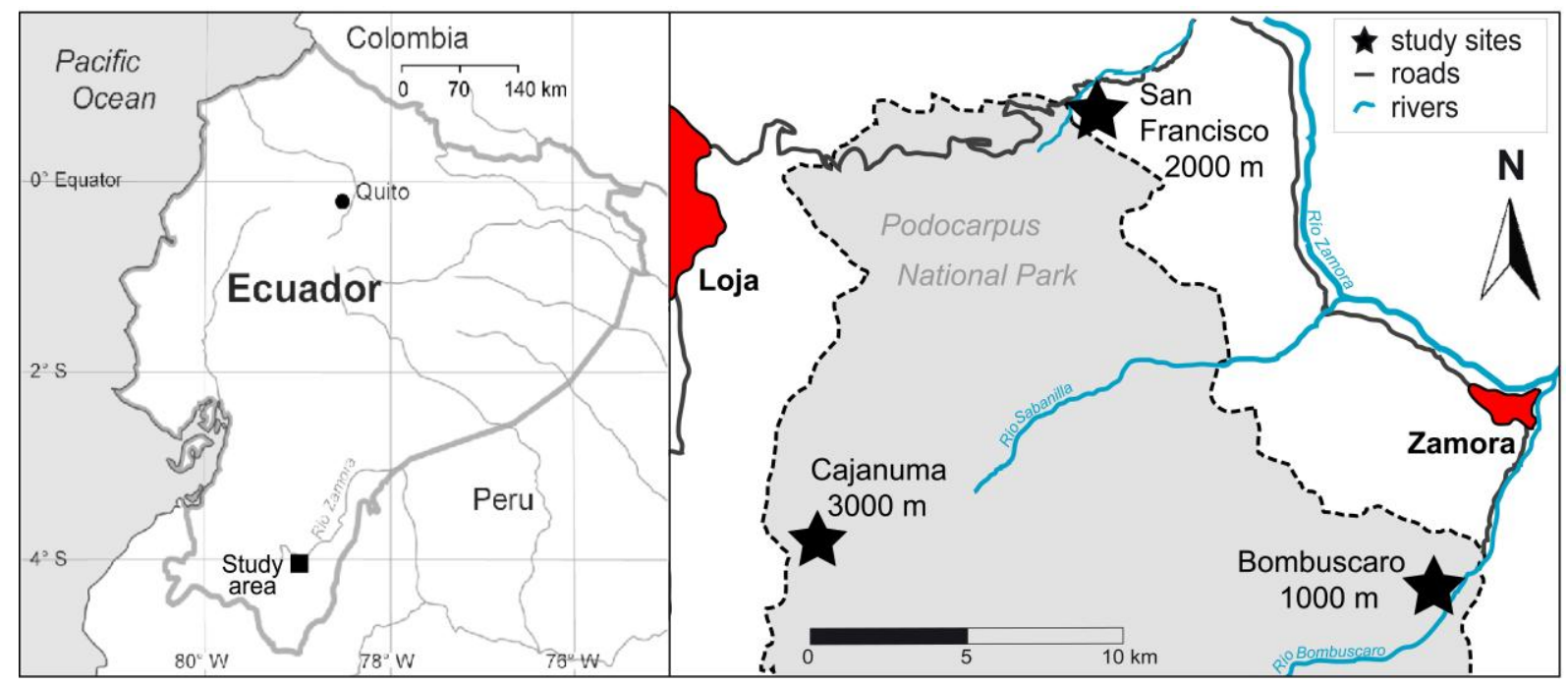

Figure 1. Location of the study area in southern Ecuador with the three stands at 1000, 2000 and $3000 \mathrm{~m}$ a.s.l.

The research area has a tropical humid climate with an extremely wet season from April to July and a less humid period from September to December (Bendix and others 2006). Regularly occurring longer dry periods do not exist. Further details on the climatic conditions at the study sites are given in Table 1.

All three stands are located in protected forest sections. Natural disturbances in the past may have included landslides in the steeply sloped terrain. The three elevations along the gradient correspond to three different forest types (Homeier and others 2008): (1) At $1000 \mathrm{~m}\left(\mathrm{~S} 4^{\circ} 7^{\prime} \mathrm{W} 78^{\circ} 58^{\prime}\right.$ ), in the transition zone between tropical lowland and lower montane forest, we find evergreen premontane forest whose trees attain heights of up to $40 \mathrm{~m}$. Common tree families of this forest type are Fabaceae, Melastomataceae, Moraceae, Myristicaceae, Rubiaceae and Sapotaceae. In this forest, we selected one tree individual per species, totaling to 15 species, at elevations between 950 and 1050 m a.s.I. Ten species were identified to the species level (see Table 3), the remaining to the genus level. (2) The evergreen lower montane forest at $2000 \mathrm{~m}\left(\mathrm{~S} 3^{\circ} 58^{\prime} \mathrm{W} 79^{\circ} 04^{\prime}\right.$ ) achieves a canopy height of 18 to 22 m. Characteristic tree families are Euphorbiaceae, Lauraceae, Melastomataceae and 
Rubiaceae. Sixteen tree species were investigated at elevations between 1800 and $1900 \mathrm{~m}$ a.s.I. Fourteen of the sixteen species could be identified to the species level. (3) The evergreen elfin-forest at $3000 \mathrm{~m}$ ( $\left.\mathrm{S} 4^{\circ} 7^{\prime} \mathrm{W} 79^{\circ} 11^{\prime}\right)$ extends up to the tree line, and the canopy height is rarely higher than 8 to $10 \mathrm{~m}$. Dominant tree families are Aquifoliaceae, Clusiaceae, Cunionaceae, Lauraceae and Melastomataceae. Ten tree species were investigated at elevations between 2850 and $3000 \mathrm{~m}$ a.s.l. situated about 100 - $200 \mathrm{~m}$ below the tree line; nine were identified to the species level. Stand structural characteristics of the three stands are summarized in Table 2.

In the three stands, photosynthesis measurements were conducted on a total of 41 trees representing 40 different species (in one species, Clethra revoluta, we selected one individual at $2000 \mathrm{~m}$ and at $3000 \mathrm{~m}$ ). Only medium to tall trees with a minimum breast height diameter ( $\mathrm{dbh}$ ) of $10 \mathrm{~cm}$ were investigated (the mean $\mathrm{dbh}$ of the sampled trees was $16 \pm 2 \mathrm{~cm}$ at $1000 \mathrm{~m}, 19 \pm 2 \mathrm{~cm}$ at $2000 \mathrm{~m}$, and $12 \pm 1 \mathrm{~cm}$ at $3000 \mathrm{~m}$ ). Tree size of the measured trees was $10-20 \mathrm{~m}$ at $1000 \mathrm{~m}, 8-15 \mathrm{~m}$ at 2000 $\mathrm{m}$ and $4-12 \mathrm{~m}$ at $3000 \mathrm{~m}$. To gain access to the sun-lit parts of the tree canopies, we selected tree individuals in the forest that grew on the steep slope beneath walking paths or below ribs on the slope, so that part of the canopy exposed to the sun could be approached from the ground.

We compiled data on the geographical distribution of the sampled families and the known altitudinal distribution of the investigated species using the online databases established by Stevens (2008) and the Missouri Botanical Gardens (2010). We used APG III (2009) for family classification. 
Table 1. Climatic and edaphic characteristics of the sampled stands (data from Moser and others (2007) and Wolf and others, unpubl.). Mean annual air temperature and relative air humidity were measured at $1.5 \mathrm{~m}$ height inside the stands at 1050,1890 and $3060 \mathrm{~m}$. Rainfall data are extrapolated from measurements in a forest gap at approximately $1050 \mathrm{~m}$ (measuring period May 2003 - May 2004), and from measurements in gaps at 1950, and $3170 \mathrm{~m}$ performed by P. Emck (3-year means, unpublished). $\left[\mathrm{CO}_{2}\right]$ is the $\mathrm{CO}_{2}$ concentration of the air above the boundary layer as estimated from air pressure and by assuming a constant mixing ratio of $370 \mu \mathrm{mol} \mathrm{CO}_{2} \mathrm{~mol}$ air ${ }^{-1}$ along the slope. $\mathrm{C} / \mathrm{N}$ ratio, available phosphorus $\left(\mathrm{P}_{\mathrm{av}}\right)$ and net $\mathrm{N}$ mineralization rate (in situ buried bag method) refer to the topsoil $(0-10 \mathrm{~cm}$, after $\mathrm{K}$. Wolf, unpubl.). Available $P$ was determined by the modified Hedley fractionation (extraction with anion exchange resins combined with $\mathrm{NaHCO}_{3}$ percolation). For the edaphic parameters, means \pm SE of 4 soil profiles dug at midslope position in the stands are given.

\begin{tabular}{|c|c|c|c|c|c|c|c|}
\hline Elevation & $m$ asl & 1000 & & 2000 & & 3000 & \\
\hline Rainfall & $m m y r^{-1}$ & c. 2230 & & c. 1950 & & c. 4500 & \\
\hline Air temperature & ${ }^{\circ} \mathrm{C}$ & & & & & & \\
\hline Mean & & 19 & & 16 & & 9 & \\
\hline $\operatorname{Max}$ & & 30 & & 29 & & 19 & \\
\hline Min & & 12 & & 8 & & 3 & \\
\hline Air humidity & $\%$ & & & & & & \\
\hline Mean & & 86 & & 91 & & 94 & \\
\hline Max & & 100 & & 100 & & 100 & \\
\hline Min & & 16 & & 29 & & 29 & \\
\hline$\left[\mathrm{CO}_{2}\right]$ & $\mathrm{Pa}$ & 33 & & 30 & & 27 & \\
\hline $\mathrm{pH}\left(\mathrm{H}_{2} \mathrm{O}\right)$ & & $4.3 \pm 0.6$ & $\mathbf{a}$ & $4.8 \pm 0.5$ & $\mathbf{a}$ & $3.7 \pm 0.1$ & $\mathbf{a}$ \\
\hline $\mathrm{C} / \mathrm{N}$ & $g g^{-7}$ & $19.0 \pm 2.5$ & $a b$ & $15.6 \pm 0.6$ & $\mathbf{a}$ & $23.9 \pm 1.4$ & b \\
\hline $\mathbf{P}_{\mathrm{av}}$ & $\mathrm{kg} \mathrm{ha}^{-1}$ & $11.8 \pm 5.3$ & $\mathbf{a}$ & $12.5 \pm 4.9$ & $\mathbf{a}$ & $5.1 \pm 0.6$ & $\mathbf{a}$ \\
\hline Net $\mathbf{N}$ mineralization & $k g N h a^{-1} 10 d^{\prime}$ & $4.0 \pm 1.6$ & $\mathbf{a}$ & $1.4 \pm 0.7$ & $a b$ & $0.6 \pm 0.4$ & b \\
\hline
\end{tabular}


Table 2. Structural characteristics of the stands at 1000, 2000 and $3000 \mathrm{~m}$ (Homeier and others, unpublished; LAl, leaf lifespan, BGB and leaf biomass: Moser and others, 2007; 2011). Presented are means \pm 1 SE for the three elevations (except for BGB). Abbreviations: $A G B$, aboveground biomass; $B G B$, belowground biomass (coarse and fine roots); $D B H$, diameter at breast height; LAl, leaf area index. Means of DBH, stem density, basal area and AGB were calculated for $9-18$ permanent plots $\left(400 \mathrm{~m}^{2}\right.$ each) covering the whole range of topographic positions at the respective elevations (trees $>10 \mathrm{~cm} \mathrm{DBH}$ ).

\begin{tabular}{|c|c|c|c|c|c|c|c|c|}
\hline Elevation & $\begin{array}{l}\text { Canopy } \\
\text { height }\end{array}$ & $\overline{\text { DBH }}$ & $\begin{array}{c}\text { Stem } \\
\text { density }\end{array}$ & $\begin{array}{c}\text { Basal } \\
\text { area }\end{array}$ & LAI & $\begin{array}{c}\text { Leaf } \\
\text { lifespan }\end{array}$ & $\overline{A G B}$ & BGB \\
\hline$m$ asl & $m$ & $\mathrm{~cm}$ & $n h a^{-7}$ & $m^{2} h a^{-7}$ & $m^{-2} m^{-2}$ & months & $M g h a^{-7}$ & $M g h a^{-7}$ \\
\hline 1000 & $25-30$ & $19 \pm 1$ a & $822 \pm 50 a$ & $29 \pm 4 a$ & $6.0 \pm 0.4 a$ & $16 \pm 3 a$ & $177 \pm 28 a$ & 32.1 \\
\hline 2000 & $16-20$ & $20 \pm 1 \quad a$ & $900 \pm 62$ a & $34 \pm 3 a$ & $5.7 \pm 0.5 a$ & $24 \pm 2 \quad b$ & $158 \pm 22 a$ & 26.1 \\
\hline 3000 & $8-10$ & $18 \pm 1 \quad a$ & $1061 \pm 84 a$ & $30 \pm 3 a$ & $2.2 \pm 0.2 \quad b$ & $25 \pm 2 \quad b$ & $89 \pm 10 b$ & 62.8 \\
\hline
\end{tabular}

\section{Photosynthesis measurements}

Light-saturated net photosynthesis $A_{\text {sat }}$ was measured on about 50 days between February and May 2009 with a portable IRGA system (LI-6400, LI-COR Biosciences, Lincoln, NE, USA) with a standard leaf chamber equipped with a LED red/blue light source (type 6400-02B). All measurements were performed between 10:00 a.m. and 4:00 p.m. Three fully expanded leaves of most distal insertion on intact twigs exposed to full sunlight were investigated per tree. Thus, every species was represented by one tree individual and three leaves. Light-saturated net photosynthesis was determined at a photon flux density of $1500 \mu \mathrm{mol} \mathrm{m} \mathrm{m}^{-2} \mathrm{~s}^{-1}$ under ambient $\mathrm{CO}_{2}$ concentration and temperature. Before starting the measurement cycle of a light response curve, the leaves were exposed to high irradiance $\left(1500 \mu \mathrm{mol} \mathrm{m} \mathrm{m}^{-2} \mathrm{~s}^{-1}\right)$ until apparent photosynthesis was stable ( $\mathrm{CV} \leq 10 \%$ ); this was achieved after $5-20 \mathrm{~min}$. In 
the subsequently measured light levels, the gas exchange system was programmed to $5 \mathrm{~min}$ for stable values before taking a reading. The measurements were conducted at mixing ratios of $370 \mathrm{ppm} \mathrm{CO}_{2}$ at all sites and at cuvette temperatures of $22-24^{\circ} \mathrm{C}$ at $1000 \mathrm{~m}, 19-21^{\circ} \mathrm{C}$ at $2000 \mathrm{~m}$ and $15-17^{\circ} \mathrm{C}$ at $3000 \mathrm{~m}$ to simulate the typical local sun canopy temperatures on a sunny day at noon (based on temperature measurements by Rollenbeck and Peters, unpublished data). The vapor pressure deficit was held constant at ambient conditions at the three sites. The $\mathrm{CO}_{2}$ release in the dark was used as an estimate of leaf dark respiration $\left(R_{D}\right)$. Prior to $R_{D}$ measurement, the intact leaves on the branches were allowed to acclimate to the dark in the chamber for 2 - 5 min. At the beginning of the measuring campaign, the $\mathrm{CO}_{2}$ analyzer was calibrated against a gas standard of $400 \mathrm{ppm} \mathrm{CO} \mathrm{CO}_{2}$ in $\mathrm{N}_{2}$. The IRGA channels were matched before each measurement. We did not check the respiration data for the possible occurrence of post-illumination burst effects; however, our $R_{D}$ data compare well with leaf dark respiration rates reported from other neo- and paleotropical tree species (e.g. Eschenbach and others 1998, Carswell and others 2000, Kenzo and others 2004, Meir and others 2007).

\section{Morphological and chemical leaf traits}

All investigated leaves were harvested for analysis of foliar $\mathrm{N}$ and $\mathrm{P}$ concentrations. Total concentrations of foliar $\mathrm{N}$ were determined with a $\mathrm{C} / \mathrm{N}$ elemental analyzer (Vario EL III, Elementar, Hanau, Germany). Total P concentrations were analyzed using an Inductively Coupled Plasma Analyzer (Optima 5300DV ICP-OES, Perkin Elmer, Waltham, Massachusetts, USA) after digesting the samples with concentrated $\mathrm{HNO}_{3}$.

\section{Data analysis}

The relationship between net photosynthesis rate and PPFD was described with a non-rectangular hyperbolic function; $90 \%$ of the $\mathrm{CO}_{2}$ assimilation rate at $1500 \mu \mathrm{mol}$ 
photons $\mathrm{m}^{-2} \mathrm{~s}^{-1}$ was taken as $A_{\mathrm{sat}}$. The initial slope of the light response curve was used to calculate the apparent quantum yield of $\mathrm{CO}_{2}$ assimilation $(\alpha)$. The data were analyzed at the stand level by pooling the 10 to 16 species of a study site. Analysis of variance (Scheffés test) was used to conduct multiple comparisons among the means of the three stands. If the data was not normally distributed according to a Shapiro-Wilk test, the Mann-Whitney two-sample test (Wilcoxon $U$ test) was used instead of Scheffés test. All calculations were conducted with SAS software (version 9.1; SAS Institute, Cary, NC, USA). A significance level of $5 \%$ was used throughout the analyses.

\section{Pan-tropical literature survey}

A literature survey was conducted to compile a data base of $A_{\text {sat }}$ values of trees from all over the tropics covering sites at variable altitudes from lowland to upper montane elevation (see Table 5 in the Appendix). This data base covers 9 studies (including the present one) with 157 tree species in 16 stands located at elevations between 100 and $3050 \mathrm{~m}$. Only measurements referring to mature or pre-mature tree individuals of non-pioneer stands were considered. Studies referring to seedlings or saplings were excluded. All study sites are located in moist tropical forests with $>1800 \mathrm{~mm}$ rainfall $\mathrm{yr}^{-1}$. $\mathrm{A}_{\text {sat }}$ values obtained at irradiances $<1200 \mu \mathrm{mol}$ photons $\mathrm{m}^{-2} \mathrm{~s}^{-1}$ were only included if that flux density was identified as being saturating. If information was available, only data referring to sun-lit, fully expanded leaves of the upper canopy were included. Wet season data were given preference over dry season data if both were available.

\section{Results}

Among the 40 tree species from 21 families investigated, light-saturated net photosynthesis at ambient temperature and $\left[\mathrm{CO}_{2}\right]$ conditions $\left(\mathrm{A}_{\mathrm{sat}}\right)$ varied in a broad 
range from 2.1 to $12.9 \mu \mathrm{mol} \mathrm{CO} \mathrm{Cm}^{-2} \mathrm{~s}^{-1}$ (Table 3, lowest value in Ilex teratopis (3000 $\mathrm{m})$, highest value in Tibouchina ochipetala, $1000 \mathrm{~m}$ ). $\mathrm{A}_{\mathrm{sat}}$ varied from 3.4 to $16.0 \mu \mathrm{mol}$ $\mathrm{m}^{-2} \mathrm{~s}^{-1}$ in the stand at $1000 \mathrm{~m}$ ( 15 species), from 7.7 to $15.4 \mu \mathrm{mol} \mathrm{m} \mathrm{m}^{-2} \mathrm{~s}^{-1}$ at $2000 \mathrm{~m}$ (16 species), and from 2.6 to $10.3 \mu \mathrm{mol} \mathrm{m} \mathrm{m}^{-2} \mathrm{~s}^{-1}$ in the uppermost stand at $3000 \mathrm{~m}(10$ species). We obtained coefficients of variation (standard deviation expressed as percent of mean) for the species collectives investigated of $36 \%(1000 \mathrm{~m}), 20 \%$ (2000 $\mathrm{m})$ and $38 \%$ (3000 $\mathrm{m})$ for the three stands.

We found no evidence in support of the assumption that trees from families restricted to the Tropics generally had higher $A_{\text {sat }}$ values than members from families with tropical and extratropical distribution range. The 21 families investigated (each represented with 1 to 6 species in the study) are arranged in Fig. 2 according to their mean photosynthetic capacity. Relatively high $A_{\text {sat }}$ values were determined in members from the Clethraceae, Rubiaceae, Siparunaceae and Anonaceae; low rates, in trees from the Clusiaceae, Nyctaginaceae, Sapotaceae and Aquifoliceae.

In our species sample from southern Ecuador, we found no clear elevational trend in $A_{\text {sat }}$ with stand means of $8.8(1000 \mathrm{~m}), 11.3(2000 \mathrm{~m})$ and $7.2 \mu \mathrm{mol} \mathrm{CO} \mathrm{m}^{-2} \mathrm{~s}^{-1}(3000$ $\mathrm{m})$. However, the 16 species of the montane stand at $2000 \mathrm{~m}$ had on average significantly higher photosynthetic capacities than the trees at 1000 or $3000 \mathrm{~m}$ (Table 3). This is also visible in Fig. 2 when comparing the species of a family at $2000 \mathrm{~m}$ (triangles) with the members from 1000 or $3000 \mathrm{~m}$ (squares and circles).

We found apparent quantum yields ( $\alpha$, the initial slope of the light response curve under ambient $\mathrm{T}$ and $\left.\left[\mathrm{CO}_{2}\right]\right)$ in the range of $0.037-0.080 \mathrm{~mol} \mathrm{CO}_{2}$ mol quanta $^{-1}$ for the 40 species (Table 3). The tree samples from the stands at 1000, 2000 and 3000 $\mathrm{m}$ were not significantly different with respect to their $\alpha$ means.

Leaf dark respiration $\left(R_{D}\right)$ at ambient temperature varied between 0.25 and 1.52 $\mu \mathrm{mol} \mathrm{CO} \mathrm{Cm}_{2}^{-2} \mathrm{~s}^{-1}$ with most species means ranging between 0.4 and $0.9 \mu \mathrm{mol} \mathrm{m} \mathrm{m}^{-2} \mathrm{~s}^{-1}$ (Table 3). The stand means of $R_{D}$ did not differ significantly at 1000, 2000 and 3000 $\mathrm{m}$ 
Table 3. Light-saturated net photosynthesis of sun leaves measured at ambient temperature and $\left[\mathrm{CO}_{2}\right]\left(\mathrm{A}_{\mathrm{sat}}\right)$, apparent quantum yield of photosynthesis $(\alpha)$, leaf dark respiration $\left(R_{D}\right)$, foliar nitrogen $\left(N_{m}\right)$ and phosphorus concentrations $\left(P_{m}\right)$ (mass-based), leaf mass per area (LMA) and leaf conductance at light saturation (mean and maximum values, $g_{\text {mean }}$ and $g_{\max }$ ) of 40 tree species at three elevations. $c=C a n o p y ~ s p e c i e s, ~ s=$ subcanopy species. Presented are means \pm SE for three leaves each per species (species level) and means \pm SE over all species of a stand. Significantly different stand level means (three elevations) are indicated by different letters $(p<0.05)$.

\begin{tabular}{|c|c|c|c|c|c|c|c|c|c|}
\hline & & $A_{\text {sat }}$ & $\alpha$ & $\mathbf{R}_{\mathbf{D}}$ & $\mathrm{N}_{\mathrm{m}}$ & $\mathbf{P}_{\mathrm{m}}$ & LMA & $\mathbf{g}_{\text {mean }}$ & $\mathbf{g}_{\max }$ \\
\hline & & $\mu \mathrm{mol} \mathrm{m}^{-2} \mathrm{~s}^{-7}$ & $\mathrm{~mol} \mathrm{~mol}^{7}$ & $\mu \mathrm{mol} \mathrm{m}^{-2} \mathrm{~s}^{-7}$ & $m g g^{-7}$ & $m g g^{-7}$ & $g m^{-2}$ & $\mathrm{~mol} \mathrm{~m} \mathrm{~m}^{-2} \mathrm{~s}^{-7}$ & $\mathrm{~mol} \mathrm{~m} \mathrm{~m}^{-2} \mathrm{~s}^{-1}$ \\
\hline \multicolumn{10}{|l|}{1000 m asl $(n=15)$} \\
\hline Saurauia spec. 1 & $s$ & $11.0 \pm 0.8$ & $0.054 \pm 0.001$ & $0.47 \pm 0.15$ & 18 & 0.8 & $102 \pm 5$ & $0.16 \pm 0.01$ & 0.22 \\
\hline Guatteria pastazae & $\mathrm{C}$ & $11.3 \pm 0.3$ & $0.066 \pm 0.001$ & $0.77 \pm 0.04$ & 18 & 0.5 & $137 \pm 3$ & $0.13 \pm 0.01$ & 0.33 \\
\hline Hedyosmum sprucei & $s$ & $12.0 \pm 0.5$ & $0.080 \pm 0.007$ & $1.33 \pm 0.16$ & 18 & 0.8 & $79 \pm 2$ & $0.08 \pm 0.01$ & 0.12 \\
\hline Inga spec. & $\mathrm{c}$ & $9.4 \pm 2.5$ & $0.060 \pm 0.001$ & $0.95 \pm 0.12$ & 26 & 0.7 & $119 \pm 3$ & $0.08 \pm 0.02$ & 0.20 \\
\hline Lozania klugii & $s$ & $9.4 \pm 0.3$ & $0.070 \pm 0.002$ & $0.66 \pm 0.05$ & 19 & 0.5 & $86 \pm 2$ & $0.17 \pm 0.01$ & 0.19 \\
\hline Licaria cf terminalis & $\mathrm{C}$ & $6.1 \pm 1.0$ & $0.054 \pm 0.002$ & $0.46 \pm 0.06$ & 26 & 0.5 & $94 \pm 1$ & $0.08 \pm 0.02$ & 0.13 \\
\hline Mollia cf gracilis & $\mathrm{C}$ & $5.4 \pm 0.4$ & $0.054 \pm 0.003$ & $0.56 \pm 0.01$ & 21 & 0.6 & $58 \pm 1$ & $0.14 \pm 0.01$ & 0.18 \\
\hline Centronia laurifolia & $s$ & $7.9 \pm 0.7$ & $0.070 \pm 0.001$ & $0.58 \pm 0.06$ & 10 & 0.2 & $138 \pm 4$ & $0.08 \pm 0.01$ & 0.11 \\
\hline Miconia spec. & $s$ & $6.9 \pm 0.5$ & $0.058 \pm 0.006$ & $0.51 \pm 0.15$ & 14 & 0.4 & $166 \pm 10$ & $0.11 \pm 0.01$ & 0.14 \\
\hline Tibouchina ochipetala & $\mathrm{s}$ & $16.0 \pm 1.0$ & $0.063 \pm 0.002$ & $1.05 \pm 0.05$ & 16 & 0.5 & & $0.20 \pm 0.02$ & 0.29 \\
\hline Ficus cervantesiana & $\mathrm{C}$ & $7.3 \pm 0.6$ & $0.060 \pm 0.006$ & $0.82 \pm 0.08$ & 13 & 0.6 & $155 \pm 18$ & $0.11 \pm 0.02$ & 0.15 \\
\hline Ficus spec. & $c$ & $8.5 \pm 0.6$ & $0.059 \pm 0.001$ & $1.06 \pm 0.13$ & 11 & 0.5 & & $0.19 \pm 0.01$ & 0.21 \\
\hline Neea cf divaricata & $s$ & $6.0 \pm 0.6$ & $0.072 \pm 0.003$ & $0.67 \pm 0.08$ & 42 & 0.7 & $73 \pm 1$ & $0.06 \pm 0.01$ & 0.09 \\
\hline Cinchona spec. & $\mathrm{C}$ & $11.1 \pm 0.5$ & $0.062 \pm 0.002$ & $1.03 \pm 0.07$ & 14 & 0.4 & $120 \pm 4$ & $0.11 \pm 0.02$ & 0.21 \\
\hline Pouteria torta & $\mathrm{C}$ & $3.4 \pm 1.7$ & $0.054 \pm 0.009$ & $0.35 \pm 0.03$ & 14 & 0.4 & $103 \pm 9$ & $0.05 \pm 0.02$ & 0.07 \\
\hline Mean & & $8.8 \pm 0.8^{a}$ & $0.062 \pm 0.002^{a}$ & $0.75 \pm 0.07$ & $19 \pm 2^{a}$ & $0.5 \pm 0.04^{a}$ & $110 \pm 6$ & a $0.12 \pm 0.01$ & \\
\hline
\end{tabular}




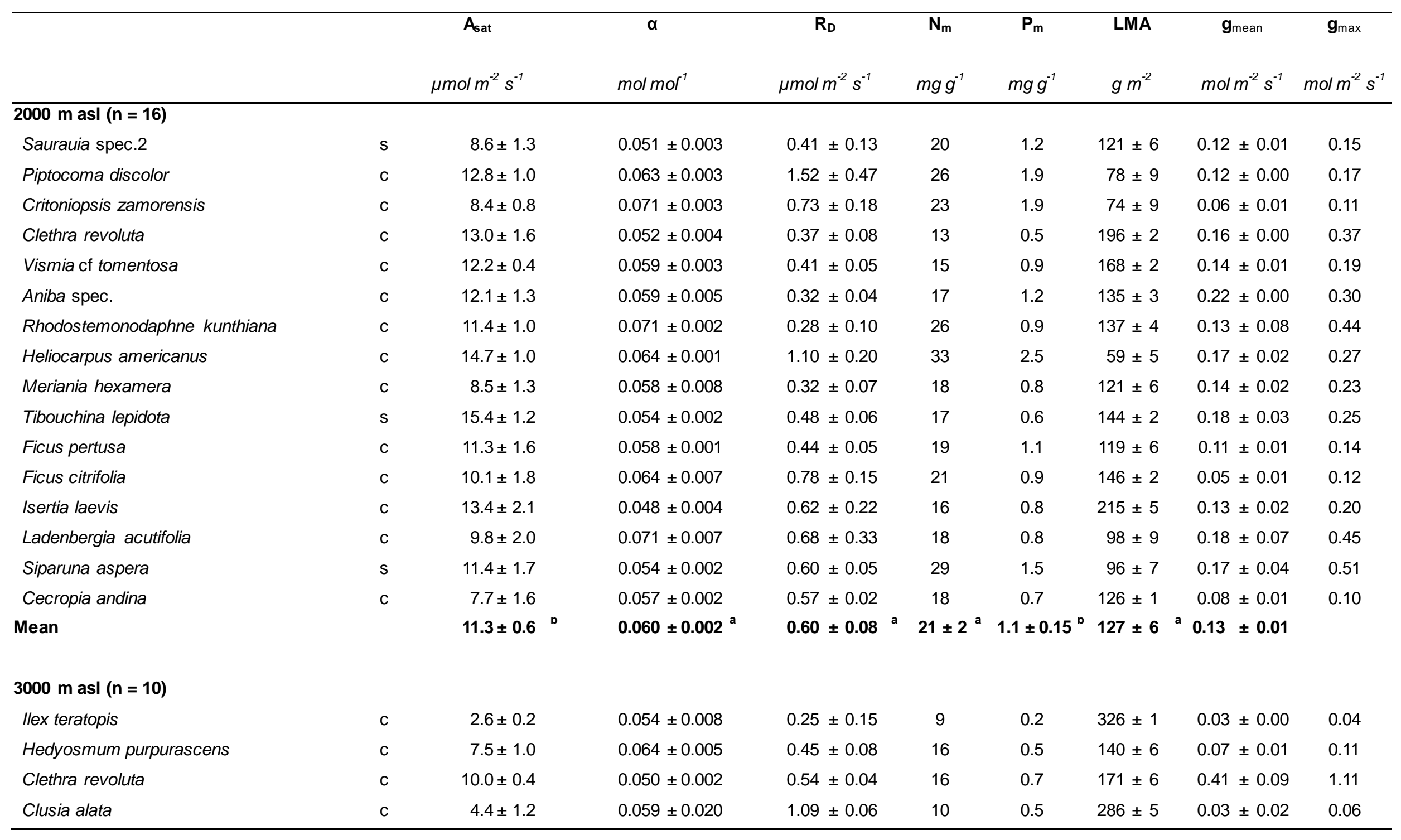




\begin{tabular}{|c|c|c|c|c|c|c|c|c|c|}
\hline & & $A_{\text {sat }}$ & $\alpha$ & $\mathbf{R}_{\mathrm{D}}$ & $\mathbf{N}_{\mathrm{m}}$ & $\mathbf{P}_{\mathrm{m}}$ & LMA & $\mathbf{g}_{\text {mean }}$ & $\mathbf{g}_{\max }$ \\
\hline Clusia elliptica & c & $5.8 \pm 1.5$ & $0.068 \pm 0.002$ & $0.77 \pm 0.19$ & 13 & 0.6 & $164 \pm 7$ & $0.05 \pm 0.01$ & 0.08 \\
\hline Persea ferruginea & c & $8.0 \pm 1.2$ & $0.038 \pm 0.005$ & $0.67 \pm 0.17$ & 10 & 0.4 & $487 \pm 9$ & $0.08 \pm 0.00$ & 0.09 \\
\hline Miconia spec. & c & $4.6 \pm 1.3$ & $0.071 \pm 0.001$ & $0.56 \pm 0.22$ & 20 & 0.7 & $98 \pm 2$ & $0.06 \pm 0.01$ & 0.09 \\
\hline Myrica pubescens & c & $10.3 \pm 0.6$ & $0.064 \pm 0.005$ & $0.74 \pm 0.29$ & 22 & 0.5 & $156 \pm 5$ & $0.11 \pm 0.01$ & 0.33 \\
\hline Mean & & $7.2 \pm 0.9$ & $0.057 \pm 0.003^{a}$ & $0.66 \pm 0.07^{a}$ & $14 \pm 1^{\circ}$ & $0.5 \pm 0.05^{\mathrm{a}}$ & $216 \pm 19^{\circ}$ & $0.11 \pm 0.04$ & \\
\hline
\end{tabular}




\section{Discussion}

\section{Among-species variation in $A_{\text {sat }}$ in species-rich tropical forests}

This study focuses on the photosynthetic capacity of mature trees with a size of at least $4 \mathrm{~m}$ (uppermost stand), typically 8 to $20 \mathrm{~m}$, in order to examine the maximum assimilation rate of sun-canopy leaves in their natural position in the canopy. We excluded seedling and sapling studies because leaf physiology may be subject to a considerable ontogenetic shift with tree ageing (e.g. Thomas and Winner 2002, Mediavilla and Escudero 2003). Measurements conducted in nearly 170 species in about 18 stands in the Americas, South-east Asia and Africa met the criteria defined in this study (see Table 5 in the Appendix).

In terms of species numbers, our study is the most comprehensive investigation conducted so far on the leaf-level photosynthesis of tropical trees; nevertheless, 170 species examined from a pool of $\sim 37.000$ taxa is still a tiny number. Similarly, our indepth study on the 40 species of the Ecuadorian TMFs represents only c. $5 \%$ of the 800 or so tree species in this study area (J. Homeier, unpubl. data). Thus, the two species samples investigated may well be not representative neither for the local nor the pantropical tree flora. The among-species variation in $\mathrm{A}_{\text {sat }}$ in the three Ecuadorian stands was indeed considerable (coefficients of variation of 20 to $38 \%$ ). Further bias may have been added to our data sets by the fact that we were not able to conduct a random selection of species or to choose them according to dominance in the three stands. Rather, species selection in Ecuador was confined to tree individuals growing on steep slopes because this allowed us to access part of their sun canopies with gas exchange equipment. This procedure guaranteed that the measured leaves were exposed to full sunlight at least part of the day and thus must have possessed partial or full sun leaf adaptation. The selection of tree species based on extensive knowledge of the ecology and distribution of the taxa in the Loja region of South Ecuador ; we chose only typical members of the closed natural forest and excluded shade-intolerant pioneer tree species. Furthermore, the phylogenetic diversity 
covered by our species sample was relatively large, including taxa from 21 families in the whole study, or 10 to 16 species from 9-12 families in each of the three stands. However, we cannot rule out the possibility that a larger survey covering additional species and families would lead to different $A_{\text {sat }}$ stand averages than the figures reported here for the Ecuadorian and pantropical analysis.

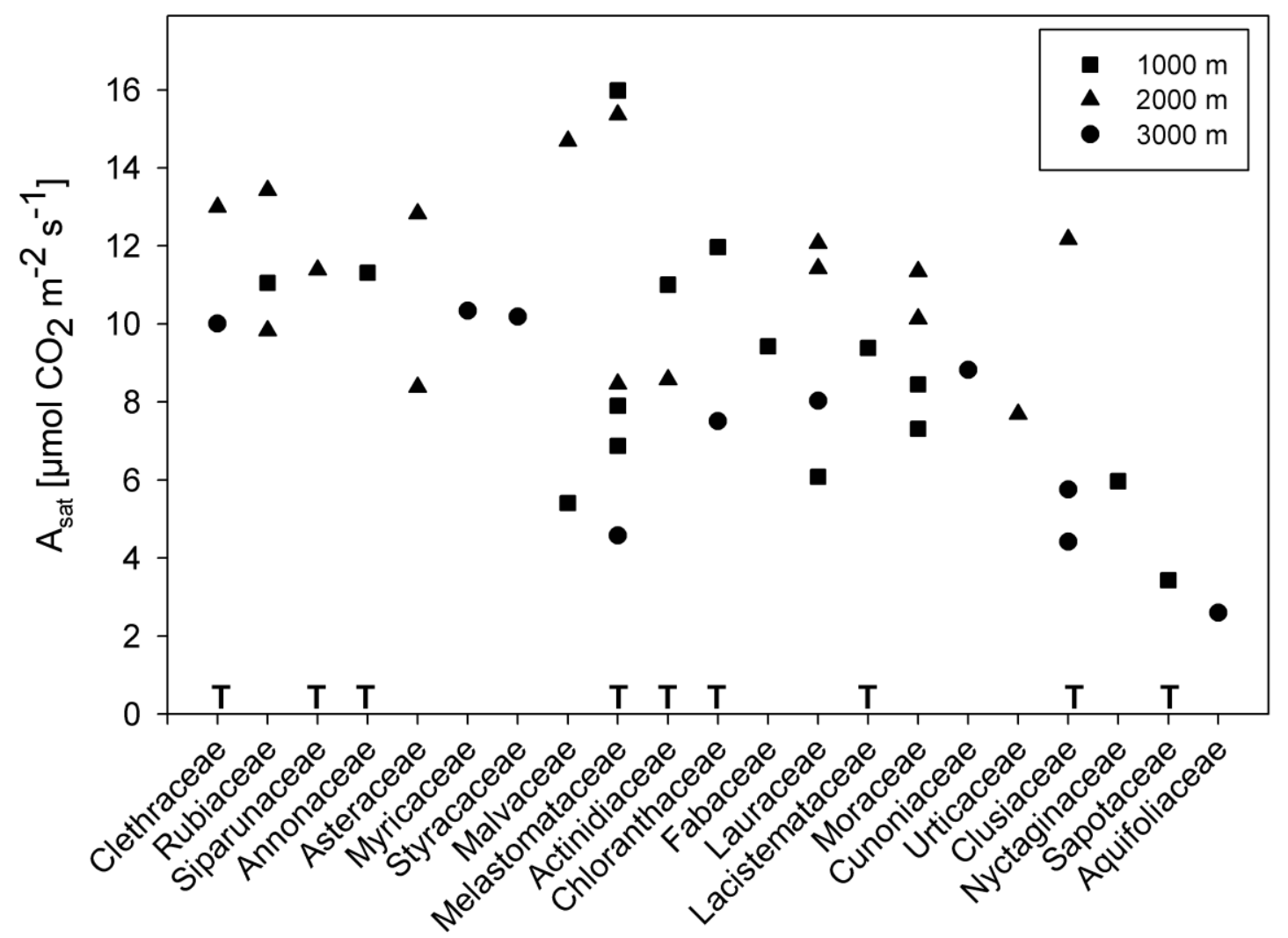

Family

Figure 2. Net photosynthesis rate of sun leaves at ambient temperature and $\left[\mathrm{CO}_{2}\right]\left(A_{\text {sat }}\right)$ averaged over all species (morphotypes) of a family at a given elevation. The 21 families are arranged from left to right according to their mean $A_{\text {sat }}$ rate. $T$ : families with restriction to the Tropics. 
Constant or decreasing photosynthetic capacity with elevation?

From our 40-species sample in Ecuador, a significant altitudinal trend in photosynthetic capacity at ambient $\left[\mathrm{CO}_{2}\right]$ and temperature did not manifest. However, we found a significantly higher $A_{\text {sat }}$ stand mean for the mid-elevation stand at $2000 \mathrm{~m}$ than at lower and higher elevation, corresponding to higher foliar $\mathrm{P}$ and $\mathrm{N}$ concentrations at this elevation. Correspondingly, species with relatively high $\mathrm{A}_{\text {sat }}$ values (>10 $\mathrm{\mu mol} \mathrm{CO}_{2} \mathrm{~m}^{-2} \mathrm{~s}^{-1}$ ) occurred mostly in this mid-elevation stand. To our knowledge, our investigation is the first that examined altitudinal changes in $A_{s a t}$ in species-rich tropical moist forests by measuring a large number of species in the adult stage and thus accounting for the characteristic species turnover along the slope. A few studies on altitudinal change in photosynthetic performance measured daily means of actual photosynthesis but not $A_{\text {sat }}$ (e.g. Cavieres and others 2000) or derived estimates of photosynthetic activity from productivity data (e.g. Kitayama and Aiba 2002). The only other transect study on altitudinal patterns in $A_{\text {sat }}$ in mature tropical trees focused on a single, polymorphic tree species (Metrosideros polymorpha, Myrtaceae) in the species-poor Hawaiian rainforests (Cordell and others 1999). Similar to our study, these authors found no change in $A_{\text {sat }}$ under ambient temperature and $\left[\mathrm{CO}_{2}\right]$ conditions between 100 and $2500 \mathrm{~m}$ a.s.l. However, $A_{\text {sat }}$ varied at unusually low levels $\left(2.3-3.8 \mu \mathrm{mol} \mathrm{CO}_{2} \mathrm{~m}^{-2} \mathrm{~s}^{-1}\right)$ across the Hawaiian transect. It may well be that this rather unproductive species reflects the specific conditions of isolated island forests, and that the results cannot simply be extrapolated to tropical forests on the continents. Moreover, altitudinal patterns in $A_{\text {sat }}$ derived from a single species with wide altitudinal distribution should differ from trends obtained from transect studies that cover a large number of species of different phylogenies, each adapted to the specific site conditions at the respective elevation level. 
Table 4. List of the 40 species from 21 families investigated in the three stands at 1000, 2000 and $3000 \mathrm{~m}$ a.s.I. in South Ecuador and their altitudinal distribution according to Missouri Botanical Garden (1981). Geographical distribution of the families according to Stevens (2010).

\begin{tabular}{|c|c|c|c|c|c|c|c|}
\hline \multirow[t]{2}{*}{ Family } & \multirow[t]{2}{*}{ Geographical distribution } & \multicolumn{2}{|l|}{$1000 \mathrm{~m}$ stand } & \multicolumn{2}{|l|}{$2000 \mathrm{~m}$ stand } & \multicolumn{2}{|l|}{$3000 \mathrm{~m}$ stand } \\
\hline & & Sampled species & $\begin{array}{l}\text { Altitudinal } \\
\text { distribution } \\
m \text { a.s.l. }\end{array}$ & Sampled species & $\begin{array}{l}\text { Altitudinal } \\
\text { distribution } \\
m \text { a.s.l. }\end{array}$ & Sampled species & $\begin{array}{l}\text { Altitudinal } \\
\text { distribution } \\
m \text { a.s.l. }\end{array}$ \\
\hline Actinidiaceae & Largely tropical, not Africa & Saurauia spec. 1 & & Saurauia spec.2 & & & \\
\hline Annonaceae & Largely tropical, pantropical & Guatteria pastazae & $390-2120$ & & & & \\
\hline Aquifoliaceae & Cosmopolitan & & & & & Ilex teratopis & $1350-3316$ \\
\hline \multirow[t]{2}{*}{ Asteraceae } & Cosmopolitan & & & Critoniopsis zamorensis & & & \\
\hline & & & & Piptocoma discolor & $100-3890$ & & \\
\hline Chloranthaceae & Tropical and subtropical, not Africa & Hedyosmum sprucei & $40-3250$ & & & Hedyosmum purpurascens & $2400-3300$ \\
\hline Clethraceae & $\begin{array}{l}\text { Largely tropical montane } \\
\text { subtropical }\end{array}$ & or & & Clethra revoluta & $456-3450$ & Clethra revoluta & $456-3450$ \\
\hline Clusiaceae & Pantropical & & & Vismia cf tomentosa & $100-2615$ & Clusia alata & $100-3200$ \\
\hline & & & & & & Clusia elliptica & $1900-3200$ \\
\hline Cunoniaceae & $\begin{array}{l}\text { Largely temperate and tropical, } \\
\text { hemisphere, few African species }\end{array}$ & S. & & & & Weinmannia pubescens & $1350-2800$ \\
\hline Fabaceae & Cosmopolitan & Inga sp. & & & & & \\
\hline Lacistemataceae & Neotropical & Lozania klugii & $100-2140$ & & & & \\
\hline Lauraceae & Pantropical (temperate) & Licaria terminalis & $1050-1440$ & Aniba spec. & & Persea ferruginea & $1400-3950$ \\
\hline
\end{tabular}




\begin{tabular}{|c|c|c|c|c|c|c|c|}
\hline \multirow[t]{2}{*}{ Family } & \multirow[t]{2}{*}{ Geographical distribution } & \multicolumn{2}{|l|}{$1000 \mathrm{~m}$ stand } & \multicolumn{2}{|l|}{$2000 \mathrm{~m}$ stand } & \multicolumn{2}{|l|}{$3000 \mathrm{~m}$ stand } \\
\hline & & Sampled species & $\begin{array}{l}\text { Altitudinal } \\
\text { distribution } \\
m \text { a.s.l. }\end{array}$ & Sampled species & $\begin{array}{l}\text { Altitudinal } \\
\text { distribution } \\
m \text { a.s.l. }\end{array}$ & Sampled species & $\begin{array}{l}\text { Altitudinal } \\
\text { distribution } \\
m \text { a.s.l. }\end{array}$ \\
\hline & & & & $\begin{array}{l}\text { Rhodoste monodaphne } \\
\text { kunthiana }\end{array}$ & $1-2150$ & & \\
\hline Malvaceae & Pantropical, also temperate & Mollia gracilis & $100-910$ & Heliocarpus americanus & $0-2615$ & & \\
\hline \multirow[t]{3}{*}{ Melastomataceae } & Largely tropical, also subtropical & Centronia laurifolia & $600-2050$ & Meriania hexamera & $1100-2900$ & Miconia spec. & \\
\hline & & Miconia spec. & & Tibouchina lepidota & $400-3230$ & & \\
\hline & & Tibouchina ochypetala & $140-2900$ & & & & \\
\hline \multirow[t]{2}{*}{ Moraceae } & Mostly tropical to warm temperate & Ficus cervantesiana & $100-2400$ & Ficus citrifolia & $0-3000$ & & \\
\hline & & Ficus spec. & & Ficus pertusa & $0-2100$ & & \\
\hline Myricaceae & Cosmopolitan & & & & & Myrica pubescens & $1500-3605$ \\
\hline Nyctaginaceae & Pantropical to warm temperate & Neea divaricata & $45-2500$ & & & & \\
\hline \multirow[t]{2}{*}{ Rubiaceae } & Cosmopolitan, but especially tropical & Cinchona spec. & & Isertia laevis & $0-2100$ & & \\
\hline & & & & Ladenbergia acutifolia & $220-1630$ & & \\
\hline Sapotaceae & Pantropical & Pouteria torta & $0-2440$ & & & & \\
\hline Siparunaceae & Neotropical and W. African & & & Siparuna aspera & $30-3300$ & & \\
\hline Styracaceae & Warm N. temperate to tropical & & & & & Styrax foveolaria & $2400-3430$ \\
\hline Urticaceae & Cosmopolitan, but mainly tropical & & & Cecropia andina & $1540-2800$ & & \\
\hline
\end{tabular}


In the absence of other transect studies on gas exchange in tropical mountains, additional information on altitudinal change in $A_{\text {sat }}$ is provided by our pan-tropical literature survey (Table 5). The data incorporated in this analysis were selected according to strict criteria with respect to tree size (mature or pre-mature trees only), successional status (no pioneer species), canopy position (sun-exposed branches only), measuring conditions (saturating light, typically >1200 $\mu \mathrm{mol} \mathrm{m} \mathrm{m}^{-2} \mathrm{~s}^{-1}$ PPFD; ambient temperature and $\left[\mathrm{CO}_{2}\right]$ ) and climate (tropical moist); this protocol excluded a number of studies on maximum photosynthesis of tropical trees that either worked with saplings, understorey or pioneer trees or apparently used non-saturating irradiances. According to this data compilation, sun leaf- $A_{\text {sat }}$ significantly decreases from tropical lowland to upper montane elevation which contradicts our first hypothesis. The linear regression equation indicates a decrease in $A_{\text {sat }}$ by about 1.3 $\mu \mathrm{mol} \mathrm{CO}_{2} \mathrm{~m}^{-2} \mathrm{~s}^{-1}$ per $\mathrm{km}$ altitude (Fig. 3: left column) or by about $0.20 \mu \mathrm{mol} \mathrm{CO}_{2} \mathrm{~m}^{-2}$ $\mathrm{s}^{-1}$ per $\mathrm{K}$ air temperature reduction (Fig. 3: centre column). The trees from lowland forests reached average photosynthetic capacities of about $10-11 \mu \mathrm{mol} \mathrm{CO}_{2} \mathrm{~m}^{-2} \mathrm{~s}^{-1}$, those of the upper montane forests of about $7 \mu \mathrm{mol} \mathrm{CO} \mathrm{CO}_{2}^{-2} \mathrm{~s}^{-1}$. The decrease in area-based $A_{\text {sat }}$ coincides not only with the temperature decrease but also with a significant decrease in foliar $P$ while no significant $N_{m}$ decrease with elevation was detected in the pantropical survey. Not only area-based, but mass-based $A_{\text {sat }}$ decreased also from lowland to upper montane elevation ( $P=0.004$; data of Table 5$)$; this indicates that the altitudinal increase in LMA, which occurred between lowland and montane elevation, was on the average not large enough to compensate the mass-based $A_{\text {sat }}$ reduction and thus to prevent a decrease in area-based $A_{\text {sat }}$. 

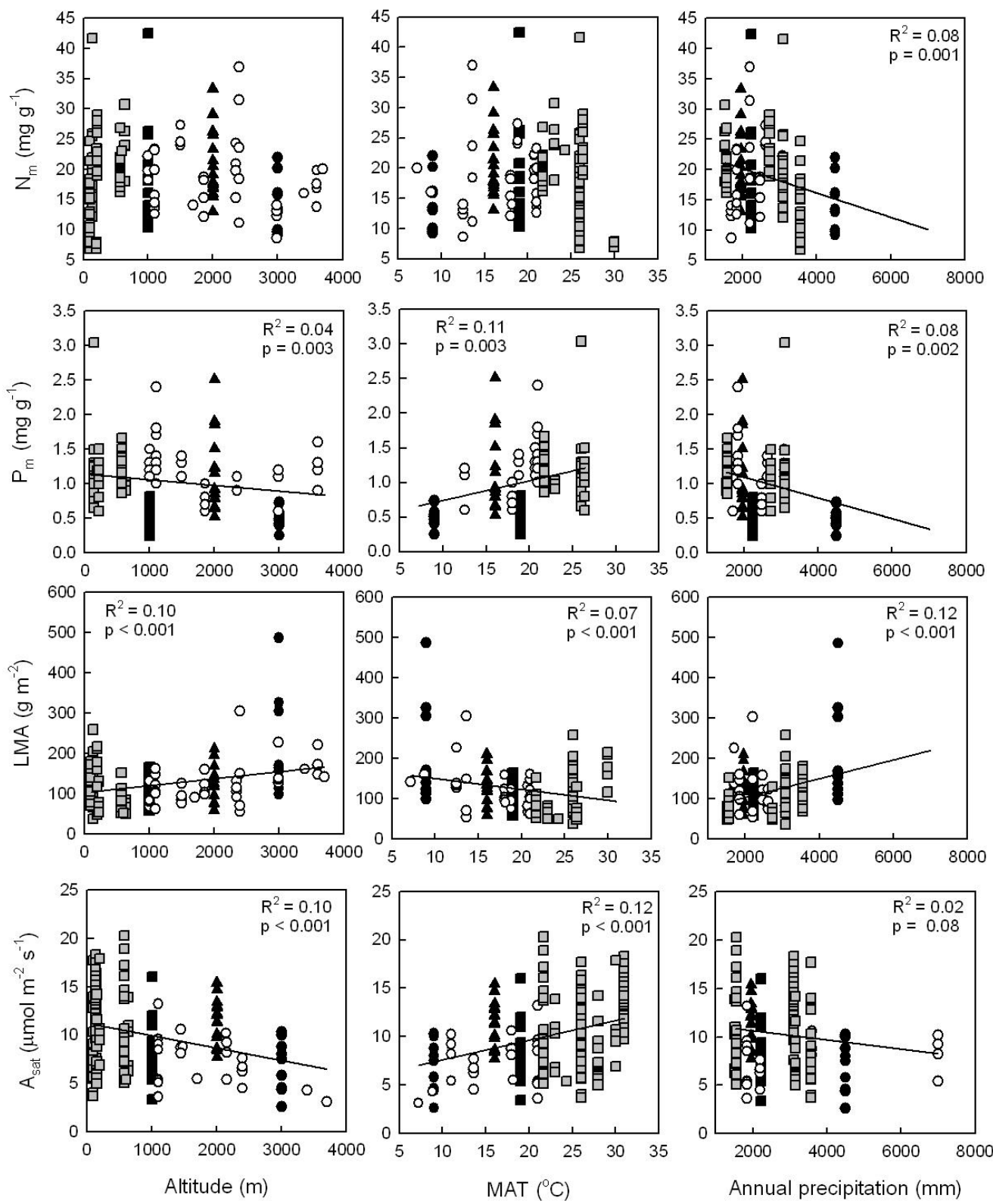

Figure 3. Dependence of light-saturated net photosynthesis at ambient temperature and $\left[\mathrm{CO}_{2}\right]\left(A_{s a t}\right)$, foliar nitrogen $\left(N_{m}\right)$ and phosporous $\left(P_{m}\right)$ concentrations (mass-based), and leaf mass per area (LMA) on elevation, temperature and precipitation in a pan-tropical data set of c. 170 tree species and 18 forest stands. Only data referring to mature or pre-mature tree individuals (no seedlings or saplings) of non-pioneer stands were included. For further explanations and references see Table 5 in the Appendix. Filled grey symbols mark the data from lowland forests, black filling indicates the data from the present study in southern Ecuador (squares - $1000 \mathrm{~m}$, triangles - $2000 \mathrm{~m}$, circles - $3000 \mathrm{~m}$ stand). 
Local edaphic and climatic conditions seem to modify this more general picture of altitudinal change in area- and mass-based $\mathrm{A}_{\text {sat }}$ considerably. While the Ecuadorian data are generally fitting quite well into to the patterns extracted from the pantropical analysis, $A_{\text {sat }}$ deviates with relatively high rates at mid-slope position $(2000 \mathrm{~m})$ from the overall trend which is explained by the relatively high soil $P$ availability in this stand. With a mean foliar P concentration of $1.1 \mathrm{mg} \mathrm{g}^{-1}$, the $2000 \mathrm{~m}$-stand fits well to the 'moderately fertile' category of Vitousek and Sanford (1986) for lowland forests, while the $1000 \mathrm{~m}$ - and $3000 \mathrm{~m}$-stands with $0.5 \mathrm{mg} \mathrm{P} \mathrm{g}^{-1}$ must be classified as 'infertile'. The very high annual rainfall amount in the $3000 \mathrm{~m}$-stand, in combination with high cloudiness, poor soil aeration and low decomposition rates, is another sitespecific factor in the Ecuador transect that may have influenced $A_{\text {sat. }}$. Upper montane forests studied in Peru at similar elevation received only half the rainfall amount (van de Weg and others, 2009) and thus grew under less extreme conditions.

The lowered $A_{\text {sat }}$ of TMF trees was evident from our analysis, even though the among-species variation was large and local edaphic and climatic factors seem to modify the effect of elevation and temperature considerably. The relatively low $A_{\text {sat }}$ differentiates tropical mountain forest trees functionally from tropical lowland trees. This difference matches with the MAT and MAP characteristics of the investigated TMF stands which place this tree group closer to the trees of temperate evergreen rainforests or temperate deciduous forests than to tropical lowland forests (Fig. 4); certain TMF stands with extremely high precipitation are even falling outside any biome range as defined by Wright and others (2004). A more detailed analysis of leaf trait relationships in the TMF tree sample shows that this group is partly deviating from the pattern of $A_{\text {sat }}$ - foliar N-LMA inter-relationships as they appear from a global perspective in the leaf economics spectrum of Wright and others (2004) (Fig. 5). One striking difference is large scatter of the data in the plot of mass-based $A_{\text {sat }}$ against SLA and $N_{m}$ in TMF trees. The surprisingly low mass-based $A_{\text {sat }}$ rates in several leaves of the TMF sample with high SLA might point at plant-internal $\mathrm{N}$ allocation patterns that are directed to an optimization of light capture at the expense of maximum carboxylation rate (Evans 1989), in a similar manner as it has been found 
in tropical understorey plants (Santiago and Wright 2007). In contrast to tropical lowland trees, many montane forest trees are exposed to continuously high cloudiness and low-light conditions which could explain this apparent functional difference to lowland trees. High variation in SLA at a relatively narrow range of mass-based $A_{\text {sat }}$ rates may offer a greater potential for optimizing $\mathrm{CO}_{2}$ assimilation in this cool, often light-limited environment (Givnish 1988, Sims and others 1994, Santiago and Wright 2007).

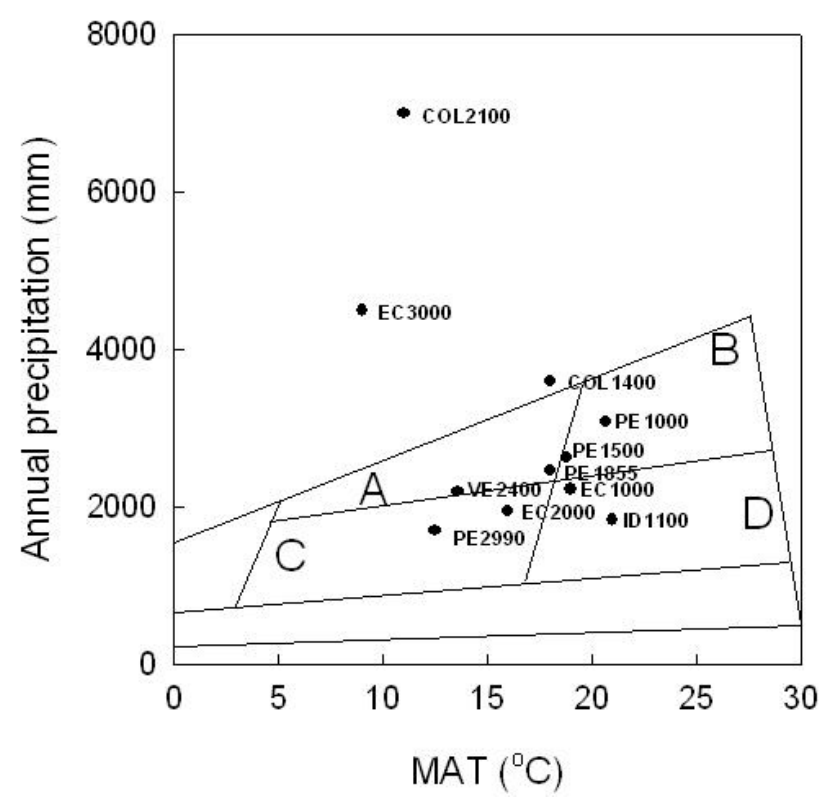

Figure 4. Grouping of the tropical montane forests considered in this study in the major biomes of the world (after Wright et al. 2004) using annual precipitation and mean annual temperature as criteria. Accordingly, these tropical montane forests have affililations either to temperate rain forests $(A)$, tropical rainforests $(B)$, temperate forests $(C)$ or tropical seasonal forests (D). Only sites located between 1000 and $3600 \mathrm{~m}$ asl are included. Locations: Ecuador (EC1000, EC2000, and EC3000, this study), Peru (PE1000, PE1500, PE1855, and PE2990, Van der Weg and others 2012), Colombia (CO1445, CO2145, Letts and Mulligan, 2005), Venezuela (VE2400, Rada and others), and Indonesia (ID1100, Hölscher and others 2006). 
Our literature survey further suggests that the range of $A_{\text {sat }}$ species means occurring in lowland forests (3.7 to $20.3 \mu \mathrm{mol} \mathrm{CO}_{2} \mathrm{~m}^{-2} \mathrm{~s}^{-1}$ ) is larger than that in montane and upper montane stands $\left(2.1\right.$ to $13.2 \mu \mathrm{mol} \mathrm{m} \mathrm{m}^{-2} \mathrm{~s}^{-1}$ ). The apparent decrease in $A_{\text {sat }}$ variation with increasing elevation is partly caused by the uneven distribution of data over the elevation range with fewer trees being studied at altitudes $>1500 \mathrm{~m}$ than at lower elevation. However, the upslope decrease in the number of investigated species mirrors the general decrease in tree species richness from tropical lowland to montane elevation (Gentry 1988, 1995; Aiba and Kitayama 1999; Slik and others 2009) and thus seems to be justified.
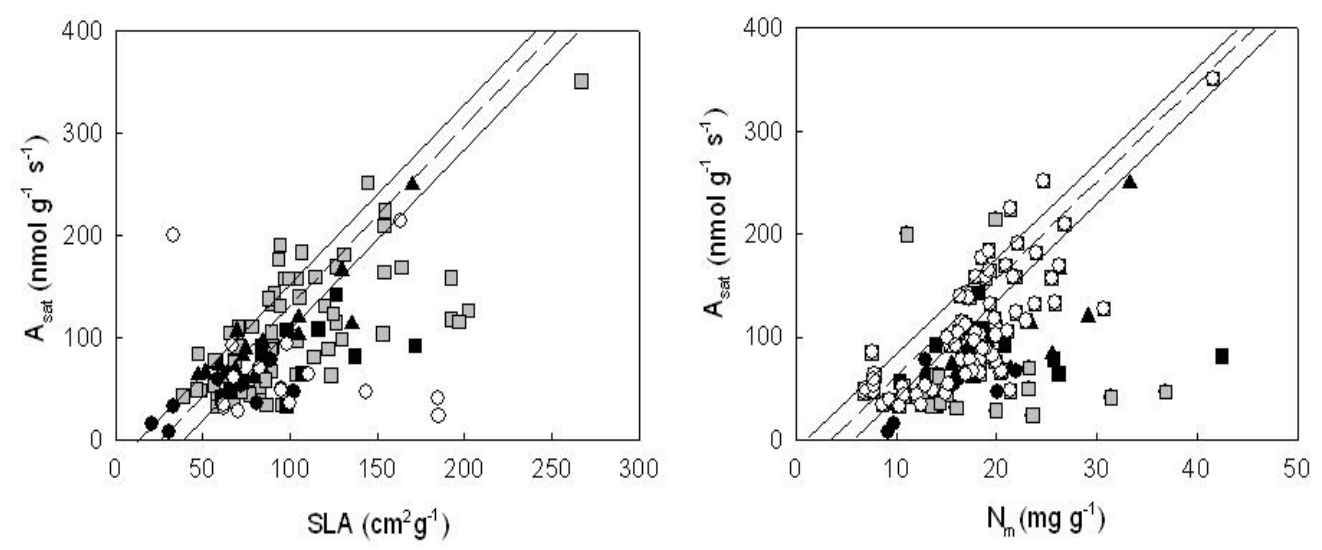

Figure 5. Relationships between photosynthetic rate per mass $\left(A_{\text {sat }}\right)$ and (left) specific leaf area $(S L A)$ or (right) leaf nitrogen per mass $\left(N_{m}\right)$ for the tree species in the survey. Filled symbols are for species from montane locations with black filling indicating the Ecuadorian species of this study (squares - $1000 \mathrm{~m}$, triangles - $2000 \mathrm{~m}$, circles - $3000 \mathrm{~m}$ stand) and grey filling species from other montane sites, open symbols stand for all other species in the survey. Dashed lines represent model II regressions with 95\% confidence intervals for the global data set of Wright and Santiago (2007) (GLOPNET).

A functional explanation of the upslope reduction in $A_{\text {sat }}$ variation is provided by stand differences in canopy structure. We expect that taller multi-layered lowland forests should generate a spatially more heterogeneous light climate than the structurally simpler high-elevation forests. This would allow at lower altitude the coexistence of 
more tree species with different strategies of light use and carbon assimilation. We assume that the large $A_{\text {sat }}$ variation in the lowland data of our literature survey (maxima up to $20 \mu \mathrm{mol} \mathrm{CO} \mathrm{CO}^{-2} \mathrm{~s}^{-1}$ ) is mirroring the co-existence of species from the full spectrum of tree functional types that are present in old-growth lowland forests, notably shade-tolerant late-successional and light-demanding gap species (Turner 2001). High-elevation forests of low stature, in contrast, are typically dense with only a single main canopy layer in which the among-species variation in photosynthetic capacity $\left(A_{\text {sat }}\right.$ typically $\left.<8 \mu \mathrm{mol} \mathrm{CO}_{2} \mathrm{~m}^{-2} \mathrm{~s}^{-1}\right)$ is indeed reduced. In the neotropical high-elevation tree genus Polylepis, which forms the highest forests of the world, the largest observed $A_{\text {sat }}$ values do not exceed $9 \mu \mathrm{mol} \mathrm{CO} \mathrm{CO}^{-2} \mathrm{~s}^{-1}$ in Argentina $(2100 \mathrm{~m})$, $7 \mu \mathrm{mol} \mathrm{CO} \mathrm{CO}^{-2} \mathrm{~s}^{-1}$ in Venezuela $\left(4200 \mathrm{~m}\right.$ ) and $3 \mu \mathrm{mol} \mathrm{CO} \mathrm{CO}^{-2} \mathrm{~s}^{-1}$ in Bolivia (4300 m, Rada and others 1996; Azocar and others 2007). Accordingly, it is not very likely that a future more extensive set of photosynthesis data from tropical high-elevation tree species would result in higher mean $A_{\text {sat }}$ values than those reported in this study.

What are the underlying causes of the apparent $A_{\text {sat }}$ decrease with elevation? The direct or indirect air pressure effects on $A_{\text {sat }}$ are probably small, in particular at low temperatures, as indicated by modeling studies of Terashima and others (1995) and Smith and Hughes (2009). A more likely explanation would be the effect of lowered temperature on the rate of RuBP carboxylation, i.e. reduced light-saturated photosynthesis rates of montane and upper montane tree species under the lowered ambient temperatures of their growing sites. Low temperatures can reduce enzyme activity in the photosynthetitic apparatus or may cause feedback inhibition of photosynthesis because of impaired sucrose metabolism and phloem loading. However, alpine and arctic plants have been found to compensate effectively for low temperatures by increasing Rubisco concentration and carboxylation capacity which is reflected by the generally relatively high foliar $N$ concentrations (Körner and Larcher 1988, Körner 1989). A prerequisite of such a compensatory response is a sufficiently high $\mathrm{N}$ and $\mathrm{P}$ supply which existed in the Ecuador TMF at $2000 \mathrm{~m}$, but $\mathrm{N}$ and P were short in supply at $3000 \mathrm{~m}$ (Moser and others 2011). Suppression of photosynthetic capacity by shortage of $\mathrm{N}$ or $\mathrm{P}$ (or other elements) in montane and 
upper montane forests is a possible scenario because the rate of nutrient cycling generally decreases at higher elevations with a reduction in temperature (Benner and others 2010). We found markedly smaller average foliar $\mathrm{N}$ concentrations in the 3000-m stand than in the other two forests (difference significant to the $2000 \mathrm{~m}$ stand). Growing deterioration of $\mathrm{N}$ and/or $\mathrm{P}$ supply with increasing elevation could limit the photosynthetic capacity of high-altitude trees by two mechanisms, by restricting the amount of $\mathrm{N}$ and $\mathrm{P}$ available for allocation to the photosynthetic machinery or by increasing mean leaf longevity and thus mean leaf age; longer-living leaves are typically more sclerophyllous and physiologically less active (Reich and others 1991; Wright and others 2004). In fact, Moser and others (2007) found tree leaf longevity to increase from 16 to 25 months on average between 1000 and 3000 $\mathrm{m}$ elevation; Further studies are needed to identify the biotic and abiotic factors causing $A_{\text {sat }}$ to decrease with elevation in tropical mountains.

As predicted, the stand means of leaf dark respiration measured at ambient temperature remained constant along the elevation transect indicating effective adaptation of mitochondrial respiration of the montane and upper montane trees to the $10 \mathrm{~K}$-temperature gradient in Ecuador. Similar homeostatic responses of leaf dark respiration were reported from gradient studies with Eucalyptus pauciflora and herbaceous plants growing at different elevations.

\section{Conclusions}

Altitudinal gradient studies may provide valuable insights into the temperature dependence of tree growth and the forest carbon balance. Canopy $\mathrm{C}$ gain is a key element of the $\mathrm{C}$ balance, but how this flux is altered with altitude in response to decreasing temperature, atmospheric $\left[\mathrm{CO}_{2}\right]$ and other factors, that change with elevation, is not well understood. The detection of more general patterns of altitudinal change in $A_{s a t}$ in tropical forests has long been hindered by the often high species diversity and difficult canopy access. Our combined approach of gas exchange 
screening in a large sample of pre-montane to upper montane neotropical tree species and a pan-tropical literature survey of carefully selected $A_{\text {sat }}$ data from low to high elevation revealed (1) a linear decrease from sea level to the alpine tree in the stand-level average of (mass- and area-related) $A_{\text {sat }}$ measured at ambient conditions, and (2) a decreasing range of among-species $A_{\text {sat }}$ variation with altitude. However, the data also suggest that (3) mountain transects with different geology and thus soil $\mathrm{N}$ and $\mathrm{P}$ availabilities might differ in their altitudinal $A_{\text {sat }}$ patterns. Our findings have implications for the search for the causes of alpine tree lines in tropical mountains. It appears that stands close to the tropical alpine tree line are built by tree species with reduced $A_{\text {sat }}$ rates, but, in addition, a reduced stand leaf area also contributes to a decease in canopy $\mathrm{C}$ gain with increasing altitude in tropical mountains (Moser et al. 2007). We interpret this result as a strong hint to carbon source limitation in tropical high-elevation forests, not supporting the hypothesis of $\mathrm{C}$ sink limitation as the principal cause of alpine tree lines (Körner 2003). Our results are in accordance with several recent studies that questioned the idea of carbon saturation in trees at high elevations (e.g. Millard and others 2007; Susiluoto and others 2007; Li and others 2008).

\section{Acknowledgements}

The authors are indebted to the German Academic Exchange Service (DAAD) for funding part of the field work and the DFG (FOR 816, subproject A2.2) for financial support. Logistic support by the Foundation Nature and Culture International ( $\mathrm{NCl}$, San Diego - Loja) is gratefully acknowledged. We thank the Ministerio del Ambiente de Ecuador for the research permit and Paul Gonzales and Linda Rohnstock for field assistance. 


\section{References}

Aiba S, Kitayama K. 1999. Structure, composition and species diversity in an altitudesubstrate matrix of rain forest tree communities on Mount Kinabalu, Borneo. Plant Ecol 140:139-157.

APG [= Angiosperm Phylogeny Group] III. 2009. An update of the Angiosperm Phylogeny Group classification for the orders and families of flowering plants: APG III. Bot J Linnean Soc 161:105-121.

Atkin OK, Evans JR, Ball MC, Lambers H, Pons TL. 2000a. Leaf respiration of snow gum in the light and dark. Interactions between temperature and irradiance. Plant Phys 122:915-924.

Atkin OK, Holly C, Ball MC. 2000b. Acclimation of snow gum (Eucalyptus pauciflora) leaf respiration to seasonal and diurnal variations in temperature: the importance of changes in the capacity and temperature sensitivity of respiration. Plant Cell Environ 23:15-26.

Atkin OK, Scheurwater I, Pons TL. 2006. High thermal acclimation potential of both photosynthesis and respiration in two lowland Plantago species in contrast to an alpine congeneric. Glob Change Biol 12:500-515.

Azocar A, Rada F, Garcia-Nunez C. 2007. Functional characteristics of the arborescent genus Polylepis along a latitudinal gradient in the high Andes. Interciencia 32:663-668.

Bendix J, Homeier J, Cueva Ortiz E, Emck P, Breckle S-W, Richter M, Beck E. 2006. Seasonality of weather and tree phenology in a tropical evergreen mountain rain forest. Int J Biometeorol 50:370-384.

Benecke U, Schulze E-D, Matyssek R, Havranek WM. 1981. Environmental control of $\mathrm{CO}_{2}$-assimilation and leaf conductance in Larix decidua Mill. Oecologia 50:5461.

Benner J, Vitousek PM, Ostertag R. 2010. Nutrient cycling and nutrient limitation in tropical montane cloud forests. Pages 90-100 in L. A. Bruijnzeel, F. N. Scatena, and L. S. Hamilton, editors. Tropical Montane Cloud Forests. Cambridge: Cambridge University Press.

Bresson CC, Kowalski AS, Kremer A, Delzon S. 2009. Evidence of altitudinal increase in photosynthetic capacity: gas exchange measurements at ambient and constant $\mathrm{CO}_{2}$ partial presssure. Ann For Sci 66:505.

Bruijnzeel LA, Scatena FN, Hamilton LS. 2010. Tropical Montane Cloud Forests. Cambridge University Press, Cambridge, UK.

Carswell FE, Meir P, Wandelli E, Bonates LCM, Kruijt B, Barbosa EM, Nobre AD, Grace J, Jarvis PG. 2000. Photosynthetic capacity in a central Amazonian rain forest. Tree Physiol 20:179-186. 
Cavieres LA, Rada F, Azocar A, Garcia-Nunez C, Cabrera HM. 2000. Gas exchange and low temperature resistance in two tropical high mountain tree species from the Venezuelan Andes. Acta Oecol 21:203-211.

Cordell S, Goldstein G, Meinzer FC, Handley LL. 1999. Allocation of nitrogen and carbon in leaves of Metrosideros polymorpha regulates carboxylation capacity and $\delta^{13} \mathrm{C}$ along an altitudinal gradient. Funct Ecol 13:811-818.

Cordell S, Goldstein G, Mueller-Dombois D, Webb D, Vitousek PM. 1998. Physiological and morphological variation in Metrosideros polymorpha, a dominant Hawaiian tree species, along an altitudinal gradient: the role of phenotypic plasticity. Oecologia 113:188-196.

Eschenbach C, Glauner R, Kleine M, Kappen L. 1998. Photosynthesis rates of selected tree species in a lowland dipterocarp rainforest of Sabah, Malaysia. Trees - Structure and Function 12:356-365.

Evans JR. 1989. Photosynthesis and nitrogen relationships in leaves of C-3 plants. Oecologia 78:9-19.

Gentry AH. 1988. Tree species richness of upper Amazonian forests. Proc Nat Acad Sci USA 85:156-159.

Ghazoul J, Sheil D. 2010. Tropical Rain Forest Ecology, Diversity, and Conservation. Oxford University Press, Oxford, UK.

Gentry AH. 1995. Patterns of diversity and floristic composition in neotropical montane forests. Pages 103-126 in H. Churchill, H. Balslev, E. Forero, and J. L. Luteyn, editors. Biodiversity and Conservation of Neotropical Montane Forests. New York: New York Botanical Garden.

Girardin CAJ, Malhi Y, Aragão L, Mamani M, Huaraca Huasco W, Durand L, Feeley KJ, Rapp J, Silva-Espejo JE, Silman MR, Salinas N, Whittaker RJ. 2010. Net primary productivity and its allocation along a tropical forest elevational transect in the Peruvian Andes. Glob Change Biol 16:3176-3192.

Givnish TJ. 1988. Adaptation to sun and shade - a whole-plant perspective. Aus $\mathrm{J}$ Plant Physiol 15:63-92.

Grubb PJ, Tanner EVJ. 1976. The montane forests and soils of Jamaica: a reassessment. J Arnold Arboretum 57:33-68.

Grubb PJ. 1977. Control of forest growth and distribution on wet tropical mountains: with special reference to mineral nutrition. Ann Rev Ecol Syst 8:83-107.

Hamilton LS, Juvik JO, Scatena FN. 1995. Tropical montane cloud forests. Springer, New York.

Hikosaka K, Nagamatsu D, Ishii HS, Hirose T. 2002. Photosynthesis- nitrogen relationships in species at different altitudes on Mount Kinabalu, Malaysia. Ecol Res 17:305-313. 
Hoch G, Popp M, Körner C. 2002. Altitudinal increase of mobile carbon pools in Pinus cembra suggests sink limitation of growth at the Swiss treeline. Oikos 98:361374.

Hölscher D, Leuschner C, Bohmann K, Hagemeier M, Juhrbandt J, Tjitrosemito S. 2006. Leaf gas exchange of trees in old-growth and young secondary forest stands in Sulawesi, Indonesia. Trees 20:278-285.

Homeier J, Werner FA, Gradstein SR, Breckle S-W, Richter M. 2008. Potential vegetation and floristic composition of Andean forests in South Ecuador, with a focus on the RBSF. Pages 87-100 in Beck E, Bendix J, Kottge I, Makeschin F, Mosandl R, Eds. Gradients in a Tropical Mountain Ecosystem of Ecuador. Berlin, Heidelberg: Springer Verlag.

Kenzo T, Ichie T, Yoneda R, Kitahashi Y, Watanabe Y, Ninomiya I, Koike T. 2004. Interspecific variation of photosynthesis and leaf characteristics in canopy trees of five species of Dipterocarpaceae in a tropical rain forest. Tree Physiol 24:1187 -1192.

Kitayama K, Aiba S-I. 2002. Ecosystem structure and productivity of tropical rain forests along altitudinal gradients with contrasting soil phosphorus pools on Mount Kinabalu, Borneo. J Ecol 90:37-51.

Körner C. 1989. The nutritional status of plants from high altitudes. Oecologia 81:379-391.

Körner C. 2003. Alpine Plant Life: Functional Plant Ecology of High Mountain Ecosystems. Berlin: Springer.

Körner C, Larcher W. 1988. Plant life in cold climates. Symp Soc Exp Biol 42: 25-57.

Lambers H, Chapin FS III, Pons TL. 2008. Plant Physiological Ecology. $2^{\text {nd }}$ ed. New York, Springer. 604 pp.

Larigauderie A, Körner C. 1995. Acclimation of leaf dark respiration to temperature in alpine and lowland plant species. Ann Bot 76:245 -252.

Letts MG, Mulligan M. 2005. The impact of light quality and leaf wetness on photosynthesis in north-west Andean tropical montane cloud forest. J Trop Ecol 21:549-557.

Leuschner C, Zach A, Moser G, Homeier J, Graefe S, Hertel D, Wittich B, Soethe N, lost S, Röderstein M, Horna V, Wolf K. in press. The carbon balance of tropical mountain forests along an altitudinal transect, Southern Ecuador. Pages in Bendix J, Beck E, Makeschin F, Mosandl R, Scheu S. (eds) Ecological Studies. Springer, Berlin.

Li MH, Xiao WF, Wang SG, Cheng GW, Cherubini P, Cai XH, Liu XL, Wang XD, Zhu WZ. 2008. Mobile carbohydrates in Himalayan treeline trees I. Evidence for carbon gain limitation but not for growth limitation. Tree Physiol 28:1287-1296. 
Lieberman D, Lieberman M, Peralta R, Hartshorn GS. 1996. Tropical forest structure and composition on a large-scale altitudinal gradient in Costa Rica. J Ecol 84:137-152.

Mediavilla S, Escudero A. 2003. Mature trees versus seedlings: Differences in leaf traits and gas exchange patterns in three co-occurring Mediterranean oaks. Ann For Sci 60:455-460.

Meir P, Levy PE, Grace J, Jarvis PG. 2007. Photosynthetic parameters from two contrasting woody vegetation types in West Africa. Plant Ecol 192:277-287.

Millard P, Sommerkorn M, Grelet G-A. 2007. Environmental change and carbon limitation in trees: a biochemical, ecophysiological and ecosystem appraisal. New Phytol 175:11-28.

Missouri Botanical Garden. 2010. Tropicos.org. Retrieved November 10, 2010, from http://www.tropicos.org.

Moser G, Hertel D, Leuschner C. 2007. Altitudinal change in LAl and stand leaf biomass in tropical montane forests: a transect study in Ecuador and a pantropical meta-analysis. Ecosystems 10:924-935.

Moser G, Roederstein M, Soethe N, Hertel D, Leuschner C. 2008. Altitudinal changes in stand structure and biomass allocation of tropical mountain forests in relation to microclimate and soil chemistry. Pages 229-242 in Beck E, Bendix J, Kottke I, Makeschin F, Mosandl R (eds) Gradients in a Tropical Mountain Ecosystem of Ecuador, Ecological studies 198. Springer, Berlin.

Moser G, Leuschner C, Hertel D, Graefe S, Soethe N, lost S. 2011. Elevation effects on the carbon budget of tropical mountain forests ( $S$ Ecuador): the role of the belowground compartment. Glob Change Biol 17:2211-2226.

Moser G, Leuschner C, Röderstein M, Graefe S, Soethe N, Hertel D. 2010. Biomass and productivity of fine and coarse roots in five tropical mountain forest stands along an altitudinal transect in southern Ecuador. Plant Ecol Diversity 3:151164.

Odegaard, F. 2000. How many species of arthropods? Erwin's estimate revised. Biol J Linnean Soc 71:583-597.

Premoli AC, Brewer CA. 2007. Environmental v. genetically driven variation in ecophysiological traits of Nothofagus pumilio from contrasting elevations. Aust J Bot 55:585-591.

Pollmann W, Hildebrand R. 2005. Structure and the composition of species in timberline ecotones of the Southern Andes. Pages 117-151 in Mountain ecosystems - studies in treeline ecology (eds Broll G, Keplin B). Springer, Berlin.

Rada F, Azócar A, Briceño B, González J, García-Núñez C. 1996. Carbon and water 
balance in Polylepis sericea, a tropical treeline species. Trees - Structure and Function 10:218-222.

Rada F, García-Núnez C, Ataroff M. 2009. Leaf gas exchange in canopy species of a Venezuelan cloud forest. Biotropica 41:659-664.

Raich JW, Russell AE, Vitousek PM. 1997. Primary productivity and ecosystem development along an elevational gradient on Mauna Loa, Hawai'i. Ecology 78:707-721.

Reich PB, Uhl C, Walters MB, Ellsworth DS. 1991. Leaf life-span as a determinant of leaf structure and function among 23 Amazonian tree species. Oecologia 86:16-24.

Reich PB, Ellsworth DS, Walters MB, Vose JM, Gresham C, Volin JC, Bowman WD. 1999. Generality of leaf trait relationships: a test across six biomes. Ecology 80:1955-1969.

Santiago LS, Goldstein G, Meinzer FC, Fisher JB, Machado K, Woodruff D, Jones T. 2004. Leaf photosynthetic traits scale with hydraulic conductivity and wood density in Panamanian forest canopy trees. Oecologia 140:543-550.

Santiago LS, Wright SJ. 2007. Leaf functional traits of tropical forest plants in relation to growth form. Func Ecol 21:19-27.

Shi P, Körner C, Hoch G. 2008. A test of the growth-limitation theory for alpine tree line formation in evergreen and deciduous taxa of the eastern Himalayas. Func Ecol 22:213-220.

Sims DA, Gebauer RLE, Pearcy RW. 1994. Scaling sun and shade photosynthetic acclimation of Alocasia macrorrhiza to whole-plant performance. 2. Simulation of carbon balance and growth at different photon flux densities. Plant Cell Environ 17:889-900.

Slayter R, Morrow P. 1977. Altitudinal variation in the photosynthetic characteristics of Snow Gum, Eucalyptus pauciflora Sieb. ex Spreng. I. Seasonal changes under field conditions in the snowy mountains area of south-eastern Australia. Aust $\mathrm{J}$ Bot 25:1-20.

Slik JWF, Raes N, Aiba S-I, Brearley FQ, Cannon CH, Meijaard E, Nagamasu H, Nilus R, Paoli G, Poulsen AD, Sheil D, Suzuki E, van Valkenburg JLCH, Webb CO, Wilkie P, Wulffraat S. 2009. Environmental correlates for tropical tree diversity and distribution patterns in Borneo. Divers Distrib 15:523-532.

Smith WK, Hughes NM. 2009. Progress in coupling plant form and photosynthetic function. Castanea 74:1-26.

Smith WK, Johnson D. 2009. Biophysical effects of altitude on plant gas exchange. Pages 257-280 in E. De la Cabrerra and W. K. Smith, editors. Biophysical Plant Ecology: Perspectives and Trends. Los Angeles: University of California 
Press.

Soethe N, Lehmann J, Engels C. 2008. Nutrient availability at different altitudes in a tropical montane forest in Ecuador. J Trop Ecol 24:397-406.

Stevens P. 2008. Angiosperm Phylogeny Website. Version 9. Retrieved November 10, 2010, from http://www.mobot.org/mobot/research/apweb/welcome.html.

Susiluoto S, Perämäki M, Nikinmaa E, Berninger F. 2007. Effects of sink removal on transpiration at the treeline: implications for the growth limitation hypothesis. Env Exp Bot 60:334-339.

Tanner EVJ, Vitousek PM, Cuevas E. 1998. Experimental investigation of nutrient limitation of forest growth on wet tropical mountains. Ecology 79:10-22.

Terashima I, Masuzawa T, Ohba H, Yokoi Y. 1995. Is photosynthesis suppressed at higher elevations due to low $\mathrm{CO}_{2}$ pressure? Ecology 76:2663-2668.

Thomas SC, Winner WE. 2002. Photosynthetic differences between saplings and adult trees: an integration of field results by meta-analysis. Tree Physiology 22:117-127.

Turner IM. 2001. The Ecology of Trees in the Tropical Rain Forest. Cambridge: Cambridge University Press.

van de Weg MJ, Meir P, Grace J, Ramos GD. 2009. Altitudinal variation in leaf mass per unit area, leaf tissue density and foliar nitrogen and phosphorus content along an Amazon-Andes gradient in Peru. Plant Ecol Diversity 2:243-254

van de Weg MJ, Meir P, Grace J, Atkin OK. 2012. Photosynthetic parameters, dark respiration and leaf traits in the canopy of a Peruvian tropical montane cloud forest. Oecologia 168:23-34.

Vitousek PM, Sanford JrRL. 1986. Nutrient cycling in moist tropical forest. Ann Rev Ecol Syst 17:137-167.

Wang HQ, Hall CAS, Scatena FN, Fetcher N, Wu W. 2003. Modelling the spatial and temporal variability in climate and primary productivity across the Luquillo Mountains, Puerto Rico. For Ecol Manage 179:69-94.

Weaver PL, Murphy PG. 1990. Forest structure and productivity in Puerto-Rico Luquillo Mountains. Biotropica 22:69-82.

Whitmore TC. 1998. An Introduction to Tropical Rain Forests. $2^{\text {nd }}$ ed. Oxford University Press, Oxford. UK.

Wieser G, Tausz M. 2007. Current concepts for treelife limitation at the upper timberline. Pages 1-18 in G. Wieser and M. Tausz, editors. Trees at their Upper Limit. Dordrecht: Springer Netherlands.

Wieser G, Oberhuber W, Walder L, Spieler D, Gruber A. 2010. Photosynthetic 
temperature adaptation of Pinus cembra within the timberline ecotone of the Central Austrian Alps. Ann For Sci 67:201. DOI: 10.1051/forest/2009094.

Wright IJ, Reich PB, Westoby M, Ackerly DD, Baruch Z, Bongers F, Cavender-Bares J, Chapin T, Cornelissen JHC, Diemer M, Flexas J, Garnier E, Groom PK, Gulias J, Hikosaka K, Lamont BB, Lee T, Lee W, Lusk C, Midgley JJ, Navas ML, Niinemets U, Oleksyn J, Osada N, Poorter H, Poot P, Prior L, Pyankov VI, Roumet C, Thomas SC, Tjoelker MG, Veneklaas EJ, Villar R. 2004. The worldwide leaf economics spectrum. Nature 428:821-827.

Zhang J-L, Cao K-F. 2009. Stem hydraulics mediates leaf water status, carbon gain, nutrient use efficiencies and plant growth rates across dipterocarp species. Funct Ecol 23:658-667.

Zhang SB, Zhou ZK, Hu H, Xu K, Yan N, Li SY. 2005. Photosynthetic performances of Quercus pannosa vary with altitude in the Hengduan Mountains, southwest China. For Ecol Manage 212:291-301. 


\section{CHAPTER 3}

Environmental and biotic controls of photosynthetic capacity in tropical trees (southern Ecuador): the role of elevation, [CO2], temperature and nutrient availability

Christoph Leuschner, Bärbel Wittich, Viviana Horna and Jürgen Homeier

Submitted to: Oecologia 


\section{Abstract}

How the photosynthetic capacity $\left(A_{\max }\right)$ of tropical trees is modified in response to the temperature and atmospheric $\left[\mathrm{CO}_{2}\right]$ reduction with increasing elevation in mountains, is not precisely known but is relevant for understanding climate warming effects on tropical forests. We measured photosynthesis in 40 tropical tree species in an elevation transect (1000 - 3000 m a.s.I.) in Ecuador and analysed the dependence of $A_{\max }$ and leaf dark respiration $\left(\mathrm{R}_{\mathrm{D}}\right)$ on important abiotic (temperature; $\left[\mathrm{CO}_{2}\right]$ ) and biotic factors (SLA; foliar N and P contents; wood specific gravity). Neither $A_{\max }$ nor $R_{D}$ showed significant elevational trends but $A_{\max }$ tended to be lowest at highest elevation. Thus, $A_{\max }$ was subject to partial, and $R_{D}$ to full homeostatic adjustment to the reductions in temperature and $\left[\mathrm{CO}_{2}\right]$ at higher elevations, mainly through a large reduction in SLA and the resulting increase in foliar $N$ and $P$ per leaf area. No elevational increase in carboxylation efficiency was detected. P content per leaf mass was the factor with tightest correlation to $A_{\max }$ across the elevation gradient. We conclude that the elevational decrease in both SLA and canopy leaf area are more important determinants of carbon gain in tropical high-elevation forests than changes in the performance of the photosynthetic apparatus.

Keywords: Elevation, $A_{\max }$, Foliar nitrogen, Foliar phosphorus, Homeostatic response, Leaf dark respiration, Photosynthesis, Tropical montane forests 


\section{Abbreviations:}

$A_{\max }$ - light-saturated net photosynthesis rate

$A_{\operatorname{maxTACA}}-A_{\max }$ at ambient temperature and $\left[\mathrm{CO}_{2}\right]$

$\mathrm{A}_{\operatorname{maxTAC} 33}-\mathrm{A}_{\max }$ at ambient temperature and $33 \mathrm{~Pa} \mathrm{CO}$ pressure

$A_{\max T 25 \mathrm{CA}}-\mathrm{A}_{\max }$ at $25^{\circ} \mathrm{C}$ and ambient $\mathrm{CO}_{2}$ pressure

$\mathrm{A}_{\max T 25 \mathrm{C} 33}-\mathrm{A}_{\max }$ at $25^{\circ} \mathrm{C}$ and $33 \mathrm{~Pa} \mathrm{CO}_{2}$ pressure

CE - carboxylation efficiency

$\left[\mathrm{CO}_{2}\right]-\mathrm{CO}_{2}$ partial pressure

$\mathrm{DBH}$ - diameter at breast height

$\mathrm{J}_{\max T A}-$ maximum electron transport rate at ambient $\mathrm{T}$

$\mathrm{J}_{\max T 25}$ - maximum electron transport rate at simulated conditions of $25^{\circ} \mathrm{C}$

LAI - leaf area index

LCP - light compensation point

LSP -irradiance needed to saturated photosynthesis

$\mathrm{N}_{\mathrm{a}}-\mathrm{N}$ content per leaf area

$N_{m}-N$ concentration per leaf mass

$\mathrm{P}_{\mathrm{a}}-\mathrm{P}$ content per leaf area

$P_{m}-P$ concentration per leaf mass

PNUE - photosynthetic nitrogen use efficiency

PPUE - photosynthetic phosphorus use efficiency

$R_{D}$ - leaf dark respiration rate

$\mathrm{R}_{\mathrm{DTA}}$ - leaf dark respiration at ambient temperature 
$\mathrm{R}_{\mathrm{DT} 25}$ - leaf dark respiration at $25^{\circ} \mathrm{C}$

SLA - specific leaf area (leaf area per mass)

Suffix 'area' $-A_{\max }$ or $R_{D}$ related to leaf area

Suffix 'mass' $-A_{\max }$ or $R_{D}$ related to leaf mass

$\mathrm{T}$ - temperature

$\mathrm{V}_{\text {cmaxTA }}$ - maximum carboxylation rate at ambient $\mathrm{T}$

$\mathrm{V}_{\text {cmaxT25 }}$ - maximum carboxylation rate at simulated conditions of $25^{\circ} \mathrm{C}$

WSG - wood specific gravity

$\alpha-$ quantum efficiency 


\section{Introduction}

The transition from lowland to upper montane forest in tropical mountains is typically characterised by a gradual decrease in tree height and a sequence of different tree species assemblages reflecting a high species turnover across the elevational belts (Gentry 1988; Kitayama 1995; Pendry and Proctor 1996; Ashton 2003; Moser et al. 2008; Bruijnzeel et al. 2010). While the changes in forest structure and species composition with increasing elevation have 'puzzled and irritated' tropical ecologists over many decades (Whitmore 1989), the underlying causes are not well understood yet because many relevant environmental factors are closely interrelated and thus are changing simultaneously with elevation. Not only does temperature decrease more or less continuously with elevation but the partial pressures of $\mathrm{CO}_{2}$ and $\mathrm{O}_{2}$ as well, while the changes in irradiance, precipitation and nutrient availability are more site-specific and less predictable (Hastenrath 1991).

Trees growing at high elevations typically exhibit characteristic morphological, chemical and physiological features such as reduced tree size, smaller but thicker leaves, a relatively high foliar $\mathrm{N}$ content per leaf area, less negative foliar $\delta^{13} \mathrm{C}$ values, high root:shoot ratios, and often relatively high wood specific gravity (Bruijnzeel and Hamilton 2000; Moser et al. 2007; Bruijnzeel et al. 2010; Milla and Reich 2011). Some of these modifications may allow the trees to maintain growth at relatively high rates despite less favourable environmental conditions at high elevations (Cordell et al. 1999). While a considerable number of studies in tropical mountains have investigated the tree size decrease and reductions in aboveground biomass and productivity with increasing elevation (e.g. Raich et al. 1997; Moser et al. 2011; Van de Weg et al. 2012; Leuschner et al. 2013), much less is known about elevational change in the photosynthetic capacity $\left(A_{\max }\right)$ of tropical trees from lowland to montane elevation.

Whether canopy carbon gain changes with elevation or not and how $A_{\max }$ adapts to the less favourable growing conditions at high elevations, is of relevance for understanding the climate warming response of tropical trees and when explanations 56 
for the conspicuous tree size reduction along mountain slopes are sought. Elevational change in photosynthetic capacity may be investigated from two perspectives, either by focussing on gas exchange data obtained at different elevations under ambient $\left[\mathrm{CO}_{2}\right]$ and temperature conditions, or by analysing assimilation data standardised to low-elevation (higher than ambient) $\mathrm{CO}_{2}$ concentrations and temperatures. The first type of data can be used for characterizing elevational change in canopy carbon gain and thus $\mathrm{C}$ source strength along mountain slopes when photosynthesis is up-scaled to the stand level, while the second information source can help to assess the adaptive potential of the photosynthetic apparatus to respond to the decreased temperature and $\left[\mathrm{CO}_{2}\right]$ at high elevation. For tropical mountain forests, both aspects are poorly studied. The few available studies on the photosynthetic performance of trees in tropical mountains fall into two categories, (1) transect studies focussing on a single tree species with wide elevational range (e.g. Cordell et al. 1998, 1999), and (2) transect studies covering the characteristic tree species turnover along tropical mountain slopes (e.g. Cavieres et al. 2000; Kitayama and Aiba 2002). In the Hawaiian tree species Metrosideros polymorpha (Myrtaceae), photosynthetic capacity was found to respond in a homeostatic manner to the less favourable $\left[\mathrm{CO}_{2}\right]$ and temperature conditions at higher elevations probably due to an increase in carboxylation efficiency (Cordell et al. 1999). However, a generally valid picture as to whether the $A_{\max }$ of tropical trees changes with elevation and how the photosynthetic apparatus of high-elevation trees has adapted to this specific environment, has not yet emerged.

Recently, Wittich et al. (2012) compiled a comprehensive $A_{\max }$ data set for tropical trees spanning an elevation distance of $2000 \mathrm{~m}$ in the southern Ecuadorian Andes that included 40 tree species from pre-montane to upper montane forests. They detected no statistically significant elevational change in the stand mean of lightsaturated net photosynthesis rate measured at ambient conditions ( $\left.A_{\max \text { TACA }}\right)$. However, when the data were placed in the broader context of a pan-tropical literature survey of published $A_{\max }$ values from mature tropical trees, a significant decrease in $A_{\max T A C A}$ by c. $1.7 \mu \mathrm{mol} \mathrm{CO}_{2} \mathrm{~m}^{-2} \mathrm{~s}^{-1}$ per $\mathrm{km}$ of elevation increase emerged 
as a global average (Wittich et al. 2012.). This result raises the question on the causes of elevational change or constancy in $A_{\max }$.

In this paper, we analyse possible controlling factors of the photosynthetic capacity of tropical trees along elevation transects using the 40 -species $A_{\text {max }}$-data set compiled by Wittich et al. (2012). We paid special attention to effects of nitrogen and phosphorus availability on the photosynthetic capacity at high elevations because earlier investigations had produced evidence for $\mathrm{N}$ and $\mathrm{P}$ limitation of tree growth in these Ecuadorian mountain forests (Graefe et al. 2010; Moser et al. 2011). The specific objectives of the study were (1) to analyse the dependence of $A_{\max }$ (measured at ambient conditions) on important abiotic factors (temperature, $\left[\mathrm{CO}_{2}\right]$ ) and plant traits (leaf morphology, foliar nutrient content, wood specific gravity, productivity), and (2) to examine the degree of up-regulation of the photosynthetic apparatus of tropical high-elevation trees in response to reduced $\left[\mathrm{CO}_{2}\right]$ and lowered temperature, assessed by comparing $A_{\max }$ rates measured at ambient conditions and rates standardised to higher (low-elevation) $\left[\mathrm{CO}_{2}\right]$ and temperature conditions. With reference to earlier studies on the photosynthetic capacity of tropical mountain forest trees (e.g. Cordell et al. 1998, 1999; Letts et al. 2010), we tested the hypotheses that (i) trees in tropical high elevation forests have higher $\mathrm{N}$ and $\mathrm{P}$ contents per leaf area, but lower contents per leaf mass, than trees at lower elevation, and (ii) they possess a higher carboxylation efficiency than trees at lower elevation. (iii) The homeostatic response in $A_{\max }$ and leaf dark respiration to lowered temperature and $\left[\mathrm{CO}_{2}\right]$ is sufficient to compensate for the less favourable environmental conditions at high elevations. 


\section{Materials and methods}

\section{Study sites and tree species}

The study was conducted between February and May 2009 in tropical pre-montane to upper montane forests along a 2000-m elevation gradient on the eastern slope of the southern Ecuadorian Andes. Three study sites were selected at c. 1000, 2000 and $3000 \mathrm{~m}$ a.s.I. within the borders of Podocarpus National Park and Reserva Biológica San Francisco in the provinces of Loja and Zamora-Chinchipe (see Fig. A1 in the Appendix). The maximum distance between the three sites was $30 \mathrm{~km}$.

The research area has a tropical humid climate with an extremely wet season from April to July (precipitation maximum in June/July) and a less humid season from September to December without regularly occurring longer dry periods (Bendix et al. 2006; Homeier et al. 2010). The microclimate close to the investigated stands was monitored from January 2008 to December 2009 (24 months) with three microclimate stations erected in gaps in the forest (ca. $20 \mathrm{~m}$ in diameter). Table A1 in the Appendix gives 2-yr averages of rainfall, air temperature, air humidity and atmospheric $\left[\mathrm{CO}_{2}\right]$ for the three elevations. While air temperature decreased more or less continuously from 1000 to $3000 \mathrm{~m}$ a.s.l. with a lapse rate of c. $6 \mathrm{~K} \mathrm{~km}^{-1}$, rainfall decreased slightly from 1000 to $2000 \mathrm{~m}$ (from about 2200 to $1800 \mathrm{~mm} \mathrm{yr}^{-1}$ ) but increased again from 2000 to $3000 \mathrm{~m}$, where clouds are frequent (to c. $2600 \mathrm{~mm} \mathrm{yr}^{-1}$ ). Against the climate variability recorded at the mid-elevation site (Breuer et al. 2013), the year 2009 received average precipitation amounts and had a slightly higher mean air temperature compared to the previous years. We estimated the $\mathrm{CO}_{2}$ partial pressure in the turbulent air above the forest canopy from local air pressure by assuming a constant mixing ratio of $370 \mu \mathrm{mol} \mathrm{CO} \mathrm{Col}^{2-1}$. Accordingly, $\left[\mathrm{CO}_{2}\right]$ decreased by c. 3 $\mathrm{Pa} \mathrm{km}{ }^{-1}$ from $33 \mathrm{~Pa}$ at $1000 \mathrm{~m}$ to $27 \mathrm{~Pa}$ at $3000 \mathrm{~m}$ (see Table A1 in the Appendix).

The mountain ridge in the study region consists of a variety of acidic bedrocks with granites dominating at $1000 \mathrm{~m}$ and phyllites and sandstones being present at elevations $>1500 \mathrm{~m}$. The soil types change along the slope from Alumic Acrisols at 
$1000 \mathrm{~m}$ to Gleyic Cambisols $(2000 \mathrm{~m})$ and Podzols $(3000 \mathrm{~m})$ at higher elevation. The availability of nitrogen $(\mathrm{N})$ and phosphorus $(\mathrm{P})$ generally decreased with elevation, but the trend was not uniform along the slope due to a geological discontinuity in the transect between 1000 and 2000 m elevation (Table A2 in the Appendix). The pools of total and available $P$ in the organic layer and in the mineral topsoil $(0-10 \mathrm{~cm})$ and soil $\mathrm{pH}$ were highest in the montane forest at $2000 \mathrm{~m}$, which stocks on moderately fertile phyllites and sandstones; the soils at $3000 \mathrm{~m}$ and also at $1000 \mathrm{~m}$ on less fertile granite had lower values. In contrast, the extractable pools of $\mathrm{NH}_{4}{ }^{+}$and $\mathrm{NO}_{3}{ }_{3}^{-}$and net $\mathrm{N}$ mineralisation and nitrification rates in the topsoil decreased four- to 30 -fold from 1000 to $3000 \mathrm{~m}$ despite the geological substrate change in the lower part of the transect.

The three investigated stands are located in protected forest sections on relatively steep slopes $\left(10-40^{\circ}\right)$ and refer to natural forest with no signs of major human disturbance. Important stand structural characteristics of the three stands are summarized in Table A3 in the Appendix. The forest inventory data reveal large decreases in mean canopy height (from 25 - 30 to 8 - 10 m), leaf area index (from 6.0 to 2.2) and aboveground biomass (from 177 to $89 \mathrm{Mg} \mathrm{DM} \mathrm{ha}^{-1}$ ) between 1000 and $3000 \mathrm{~m}$ elevation but only minor change in stem density, stand basal area and mean DBH. In contrast, belowground biomass increased greatly with elevation from 32 to $63 \mathrm{Mg} \mathrm{ha}^{-1}$. The pool of $\mathrm{N}$ stored in stand leaf biomass increased from 123 to $202 \mathrm{~kg}$ $\mathrm{ha}^{-1}$ between 1000 and $2000 \mathrm{~m}$, probably as a consequence of the geological discontinuity, and dropped to only $46 \mathrm{~kg} \mathrm{ha}^{-1}$ toward the uppermost stand. Similarly, the foliar P pool doubled between 1000 and $2000 \mathrm{~m}$ and reached its minimum at $3000 \mathrm{~m}$. Mean leaf lifespan as determined by leaf tagging and repeated censuses increased from $16(1000 \mathrm{~m})$ to 25 months $(3000 \mathrm{~m})$.

With $\geq 800$ tree species the forests in the study area are extremely species rich (J. Homeier, unpubl. data). At every site, we selected 10-16 tree species that belonged to the more abundant taxa at this elevation and thus were considered as being more or less representative of the local tree assemblage. Another selection criterion was that at least a few trees were accessible from the ground for gas exchange 60 
measurements.

The three elevations correspond to different forest types (Homeier et al. 2008): The $1000 \mathrm{~m}$ stand $\left(\mathrm{S} 4^{\circ} 7^{\prime} \mathrm{W} 78^{\circ} 58^{\prime}\right.$ ) is situated at pre-montane elevation in the transition zone between tropical lowland and lower montane forest with a canopy up to $40 \mathrm{~m}$ high. Common tree families are Fabaceae, Melastomataceae, Moraceae, Myristicaceae, Rubiaceae and Sapotaceae. In this stand, one tree individual of each of the 15 species was selected for photosynthesis measurement at elevations between 950 to $1050 \mathrm{~m}$ a.s.I. Ten species could be identified to the species level, the remaining to the genus level (Table A4 in the Appendix).

The $2000 \mathrm{~m}$ stand ( $3^{\circ} 58^{\prime} \mathrm{W} 79^{\circ}$ 04') is an evergreen lower montane forest of 18 to $22 \mathrm{~m}$ canopy height. Characteristic tree families are Euphorbiaceae, Lauraceae, Melastomataceae and Rubiaceae. Sixteen tree species were investigated at elevations between 1800 and 1900 m a.s.l. with 14 of the species being identified to the species level.

The stand at $3000 \mathrm{~m}\left(\mathrm{~S} 4^{\circ} 7^{\prime} \mathrm{W} 79^{\circ} 11^{\prime}\right.$ ) is an evergreen elfin forest located 100-200 $\mathrm{m}$ below the alpine tree line with a canopy height rarely exceeding 8 to $10 \mathrm{~m}$. Dominant tree families are Aquifoliaceae, Clusiaceae, Cunionaceae, Lauraceae and Melastomataceae. Here, ten tree species were investigated at elevations between 2850 and 3000 m a.s.l.; nine could be identified to the species level.

In total, we were able to conduct photosynthesis measurements in 41 trees representing 40 different species (for one species, Clethra revoluta, we selected each one individual at $2000 \mathrm{~m}$ and $3000 \mathrm{~m}$ ). Maximum distance between the trees at a site was $1.5 \mathrm{~km}$. Only medium to tall trees with a minimum breast height diameter (DBH) of $10 \mathrm{~cm}$ were investigated (the mean $\mathrm{DBH}$ of the sampled trees was $16 \pm 2 \mathrm{~cm}$ at $1000 \mathrm{~m}, 19 \pm 2 \mathrm{~cm}$ at $2000 \mathrm{~m}$, and $12 \pm 1 \mathrm{~cm}$ at $3000 \mathrm{~m})$. The measured trees were $10-20 \mathrm{~m}$ tall at $1000 \mathrm{~m}, 8-15 \mathrm{~m}$ at $2000 \mathrm{~m}$ and 4-12 $\mathrm{m}$ at $3000 \mathrm{~m}$. For accessing the sun-lit parts of the tree canopies with the gas exchange system, we selected tree individuals in the forest that grew on the steep slope below walking paths or trees growing below ribs on the slope, so that part of the sun-exposed canopy was 
accessible from the ground.

Data on stand structure, aboveground biomass fractions, DBH increment (in percent of basal area) and wood specific gravity of the studied species were collected in the course of a comprehensive inventory on stand structure and productivity in 54 plots of $400 \mathrm{~m}^{2}$ size in close vicinity of the trees used for photosynthesis measurement at 1000, 2000 and 3000 m elevation (J. Homeier, unpubl. data). Data on belowground biomass, leaf life span and leaf area index refer to three additional plots located at 1000, 2000 and $3000 \mathrm{~m}$ in close vicinity of the photosynthesis trees (data from Moser et al. 2007; consult this source also for description of methods).

\section{Photosynthesis measurements}

Between February and May 2009, we measured leaf gas exchange on each three replicate leaves of the 41 trees (40 species; 123 leaves in total) using a portable IRGA system (LI-6400, LI-COR Biosciences, Lincoln, NE, USA) equipped with a LED $\mathrm{red} / \mathrm{blue}$ light source (type 6400-02B). At the beginning of the measuring campaign, the $\mathrm{CO}_{2}$ analyser was calibrated against a gas standard of $400 \mathrm{ppm} \mathrm{CO} \mathrm{CO}_{2}$ in $\mathrm{N}_{2}$. The IRGA channels were matched before every measurement. All measurements were carried out between 10:00 a.m. and 4:00 p.m. on intact fully expanded leaves of most distal insertion on branches that were not detached during measurement. The branches were part of the lateral canopy with exposure to full sunlight. For every leaf, a light and $\mathrm{CO}_{2}$ response curve was recorded. The temperature simulated in the cuvette was set to the air temperature found to be typical for the measurement time at the respective study site based on temperature measurements by Rollenbeck and Peters (unpublished data), i.e. $22-24^{\circ} \mathrm{C}$ at $1000 \mathrm{~m}, 19-21^{\circ} \mathrm{C}$ at $2000 \mathrm{~m}$ and $15-17^{\circ} \mathrm{C}$ at $3000 \mathrm{~m}$. The water vapour saturation deficit in the cuvette was held constant at vpd levels that were characteristic for the mean ambient conditions at the respective sites, i.e. $1.6 \mathrm{kPa}$ at $1000 \mathrm{~m}, 1.2 \mathrm{kPa}$ at $2000 \mathrm{~m}$ and $0.9 \mathrm{kPa}$ at $3000 \mathrm{~m}$. The photosynthetic light response was determined at photon flux densities of 1500, 1000, 
$500,200,100,50,20$ and $0 \mu \mathrm{mol} \mathrm{m} \mathrm{m}^{-1}$ starting at highest irradiance. In this measuring task, the $\mathrm{CO}_{2}$ /air mixing ratio was held constant at $370 \mathrm{ppm}$. The photosynthetic $\mathrm{CO}_{2}$ response was measured under light saturation (1500 $\mu \mathrm{mol}$ photons $\mathrm{m}^{-2} \mathrm{~s}^{-1}$ ) at $\mathrm{CO}_{2}$ mixing ratios of $2000,1300,700,360,200,100,50$ and 0 ppm starting at the highest ratio. The $\mathrm{CO}_{2}$ release recorded in the dark at the end of the $\mathrm{CO}_{2}$ response curve was assumed to give an estimate of leaf dark respiration $\left(R_{D}\right)$. Prior to respiration measurement, the leaves were allowed to acclimate for $2-5$ min to the dark in the cuvette.

Besides the $A_{\max }$ measurements conducted at ambient temperature and $\left[\mathrm{CO}_{2}\right]$ conditions, we also calculated for the trees at 2000 and $3000 \mathrm{~m}$ the expected photosynthetic capacity under low-elevation $(1000 \mathrm{~m})$ conditions, i.e. at a temperature of $25^{\circ} \mathrm{C}$ and/or $\mathrm{CO}_{2}$ partial pressure of $33 \mathrm{~Pa}\left(\mathrm{~A}_{\max 25 \mathrm{CA}}, \mathrm{A}_{\max \text { TAC33 }}\right.$ and $\left.A_{\max 25 \mathrm{C} 33}\right)$. This allowed comparing the higher elevation trees with those at $1000 \mathrm{~m}$

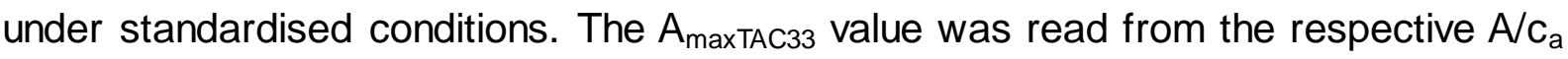
curve, while the $A_{\max }$ rate at $25{ }^{\circ} \mathrm{C}$ was calculated by correcting the $A_{\max T A C A}$ value according to a temperature function of $A_{\max }$ derived for wheat plants by de Pury and Farquhar (1997) because of the lack of adequate data for tropical trees. A similar approach was chosen by earlier authors (e.g. Meir et al. 2007). The $\mathrm{CO}_{2}$ partial pressure at 1000, 2000 and $3000 \mathrm{~m}$ was calculated from the equation

$\mathrm{P}_{\mathrm{CO} 2}=\mathrm{X} \times \mathrm{P}_{\mathrm{atm}} \times 10^{-6}$

where $\mathrm{P}_{\mathrm{CO} 2}$ is the partial pressure of $\mathrm{CO}_{2}$ at a given elevation, $\mathrm{X}$ the molar fraction of $\mathrm{CO}_{2}$ in ppm (which was assumed to be constant with elevation), and $\mathrm{P}_{\text {atm }}$ the local air pressure at this elevation. The mean air pressure was $c .90 \mathrm{kPa}$ at $1000 \mathrm{~m}, 80 \mathrm{kPa}$ at $2000 \mathrm{~m}$ and $72 \mathrm{kPa}$ at $3000 \mathrm{~m}$.

The photosynthetic response to a variable PPFD at ambient $\left[\mathrm{CO}_{2}\right]$ was described with a non-rectangular hyperbolic function (Norman et al. 1992); ninety percent of the measured assimilation rate at $1500 \mu \mathrm{mol}$ photons $\mathrm{m}^{-2} \mathrm{~s}^{-1}$ was taken as $A_{\max }$ and the corresponding photon flux density as the saturating irradiance of photosynthesis (light saturation point, LSP). The initial slope $\alpha$ of the light response curve was used 
to calculate the quantum yield of photosynthesis. For fitting the $A / c_{i}$ curves, the program RACCIA (Fleck 2002) was used which is based on the equations of Farquhar et al. Berry (1980), Harley and Tenhunen (1991) and Ball et al. (1987). Carboxylation efficiency (CE) was derived from the initial slope of the $A / c_{i}$ curve.

\section{Morphological and chemical leaf trait analysis}

For all 123 leaves measured, we determined dry weight, leaf size and foliar nutrient content. The harvested fresh leaves were scanned and their areas measured with an optical analysis system (WinFolia, Quebec, Régent, Canada). After drying at $70{ }^{\circ} \mathrm{C}$ for $48 \mathrm{~h}$, the leaves were weighed and the specific leaf area calculated. The $\mathrm{N}$ concentration of the dry leaf mass was measured with an elemental analyser (Vario EL III, Elementar, Hanau, Germany), the P concentration with an Inductively Coupled Plasma Analyser (Optima 5300DV ICP-OES, Perkin Elmer, Waltham, Mass., USA) after $\mathrm{HNO}_{3}$ pressure digestion. The foliar $\mathrm{N}$ and $\mathrm{P}$ contents were expressed either per leaf area $\left(\mathrm{N}_{a}, \mathrm{P}_{\mathrm{a}}\right)$ or per leaf mass $\left(\mathrm{N}_{\mathrm{m}}, \mathrm{P}_{\mathrm{m}}\right)$. The $\delta^{13} \mathrm{C}$ signature of the leaf mass was analysed by mass spectroscopy (Delta plus, ThermoFinnigan, USA) in the Stable Isotope Laboratory of Göttingen University.

\section{Statistical analysis}

The photosynthesis data were analysed for their elevation dependence by pooling the 10 to 16 species of a study site; the species averages consist of the each three leaves per species examined. Analysis of variance (Scheffé's test) was used to conduct multiple comparisons among the means of the three sites. If the data were not normally distributed according to a Shapiro-Wilk test, the Mann-Whitney twosample test (Wilcoxon $U$ test) was used instead of Scheffé's test. All calculations were done with SAS software (version 9.1; SAS Institute, Cary, NC, USA). A significance level of $5 \%$ was used throughout the analyses. 
The relationship between photosynthetic parameters and leaf traits or productivity variables was analysed by simple linear regressions (based on species averages; conducted with the software SigmaPlot, version 11.0, Systat Software, Inc, Washington, USA). Multiple linear regression analyses with backward variable elimination (software R 2.13.0, R Development Core Team 2011) were applied to test which model built with the possibly influencing factors $\mathrm{CO}_{2}$, temperature, $\mathrm{P}_{\mathrm{a}}, \mathrm{N}_{\mathrm{a}}, \mathrm{SLA}$ and wood specific gravity predicted $A_{\max }$ best. We conducted two separate analyses, one with the complete set of variables but excluding $\mathrm{CO}_{2}$, and a second one excluding temperature, since these two variables were highly correlated (Table 1). A correlation coefficient of $R>0.7$ was used as a threshold to exclude predictor variables in the same model. Criterion for selecting the best model was the AIC (Akaike information criterion) score. We selected the model with the minimum AIC value.

Table 1. Results of Pearson correlation analyses between seven biophysical and biotic variables with a possible influence on photosynthesis. Given are the $\mathrm{R}$ values and the direction on the relationships.

\begin{tabular}{|c|c|c|c|c|c|c|c|c|}
\hline & & $\begin{array}{l}\mathbf{T} \\
{ }^{\circ} \mathrm{C}\end{array}$ & $\begin{array}{c}\mathbf{P}_{\mathbf{a}} \\
m g m^{2}\end{array}$ & $\begin{array}{c}\mathbf{N}_{\mathbf{a}} \\
g m^{2}\end{array}$ & $\begin{array}{c}\mathbf{P}_{\mathbf{m}} \\
m g g^{1}\end{array}$ & $\begin{array}{c}\mathbf{N}_{\mathbf{m}} \\
m g g^{1}\end{array}$ & $\begin{array}{c}\text { SLA } \\
\mathrm{cm}^{2} \mathrm{~g}^{1}\end{array}$ & WSG \\
\hline$\left[\mathrm{CO}_{2}\right]$ & $P a$ & 0.96 & -0.45 & -0.41 & -0.02 & 0.26 & 0.48 & -0.23 \\
\hline $\mathbf{T}$ & ${ }^{\circ} \mathrm{C}$ & & -0.49 & -0.39 & -0.09 & 0.23 & 0.45 & -0.24 \\
\hline $\mathbf{P}_{\mathrm{a}}$ & $m g m^{-2}$ & & & 0.56 & 0.54 & 0.00 & -0.29 & -0.03 \\
\hline $\mathrm{N}_{\mathrm{a}}$ & $g m^{-2}$ & & & & -0.11 & 0.05 & -0.58 & 0.14 \\
\hline $\mathbf{P}_{\mathrm{m}}$ & $m g g^{1}$ & & & & & 0.59 & 0.57 & -0.27 \\
\hline $\begin{array}{l}\mathrm{N}_{\mathrm{m}} \\
\text { SLA }\end{array}$ & $\begin{array}{l}m g g^{1} \\
c m^{2} q^{1}\end{array}$ & & & & & & 0.70 & $\begin{array}{l}-0.23 \\
-0.21\end{array}$ \\
\hline
\end{tabular}


Table 2. Means over all investigated species ( \pm SE) for about 30 parameters of photosynthetic activity, leaf dark respiration, and leaf morphology and chemistry in the three stands at 1000, 2000 and $3000 \mathrm{~m}$ a.s.l. $(\mathrm{N}=10-16$ species, three leaves per species investigated). $N_{m}, P_{m}-N$ or $P$ per leaf mass; $N_{a}, P_{a}-N$ or $P$ per leaf area; $A_{\text {maxTACA }}$ - lightsaturated net photosynthesis rate per leaf area at ambient temperature and $\left[\mathrm{CO}_{2}\right] ; A_{\operatorname{maxTAC} 33}$, $A_{\text {maxT25CA}}, A_{\max 25 C_{33}}-A_{\max }$ at simulated conditions of ambient $\mathrm{T}$ and $33 \mathrm{~Pa} \mathrm{CO}_{2}$, or $25^{\circ} \mathrm{C}$ and ambient $\mathrm{CO}_{2}$, or $25{ }^{\circ} \mathrm{C}$ and $33 \mathrm{~Pa} \mathrm{CO}_{2} ; \mathrm{V}_{\mathrm{cmaxT}}, \mathrm{V}_{\mathrm{cmaxT} 25}$ - maximum carboxylation rate at simulated conditions of ambient $\mathrm{T}$ or at $25^{\circ} \mathrm{C}$; $\mathrm{J}_{\operatorname{maxTA}}, \mathrm{J}_{\max T 25}$ - maximum electron transport rate at simulated conditions of ambient $\mathrm{T}$ or at $25{ }^{\circ} \mathrm{C}$; $\alpha$ - quantum efficiency; CE carboxylation efficiency; LCP and LSP - light compensation point and light saturation point of photosynthesis; $\mathrm{CO}_{2} \mathrm{CP}-\mathrm{CO}_{2}$ compensation point; PNUE and PPUE - instantaneous photosynthetic $N$ and $P$ use efficiency; $A_{\text {maxmassTACA }}$ - mass-specific $A_{\max }$ at ambient $T$ and $\left[\mathrm{CO}_{2}\right] ; A_{\text {maxmassTAC33}}, A_{\text {maxmassT25CA }}$ and $A_{\text {maxmassT25C33 }}$ - mass-specific $A_{\max }$ at simulated conditions of ambient $\mathrm{T}$ and $33 \mathrm{~Pa} \mathrm{CO}$, or $25{ }^{\circ} \mathrm{C}$ and ambient $\mathrm{CO}_{2}$, or $25^{\circ} \mathrm{C}$ and $33 \mathrm{~Pa} \mathrm{CO}_{2}$; $R_{D T A}$ and $R_{D T 25}$ - leaf dark respiration rate at ambient $T$ or $25{ }^{\circ} \mathrm{C} ; \delta^{13} \mathrm{C}$ - leaf $\delta^{13} \mathrm{C}$ signature. Significantly different means between the three elevations are indicated by different letters $(P$ $<0.05)$. SLA, $N_{m}, P_{m}, N_{a}, P_{a}, A_{\text {maxtACA, }} \alpha$ and $R_{D T A}$ data after Wittich et al. (2012).

\begin{tabular}{|c|c|c|c|c|c|c|c|c|}
\hline & & & $00 \mathrm{~m}$ & & $2000 \mathrm{~m}$ & & $3000 \mathrm{~m}$ & \\
\hline No. of tree species & & & 15 & & 16 & & 10 & \\
\hline No. of families & & & 12 & & 11 & & 9 & \\
\hline \multicolumn{9}{|l|}{$\begin{array}{l}\text { Leaf and stand } \\
\text { structural traits }\end{array}$} \\
\hline Leaf size & $\mathrm{cm}^{2}$ & 127 & \pm 24 & $\mathbf{a}$ & $145 \pm 32$ & $\mathbf{a}$ & $40 \pm 11$ & b \\
\hline SLA & $\mathrm{cm}^{2} \mathrm{~g}^{-1}$ & 100 & \pm 9 & a & $90 \pm 8$ & a & $57 \pm 8$ & b \\
\hline Rel. dbh increment & $\% y r^{-1}$ & 1.20 & \pm 0.21 & a & $0.88 \pm 0.18$ & a & $0.92 \pm 0.16$ & a \\
\hline Wood spec. gravity & & 0.52 & \pm 0.03 & a & $0.48 \pm 0.02$ & $\mathbf{a}$ & $0.56 \pm 0.02$ & $\mathbf{a}$ \\
\hline $\mathrm{N}_{\mathrm{m}}$ & $m g g^{-1}$ & & \pm 2 & ab & $21 \pm 2$ & a & $14 \pm 1$ & b \\
\hline$P_{m}$ & $m g g^{-1}$ & 0.5 & \pm 0.04 & a & $1.1 \pm 0.15$ & b & $0.5 \pm 0.05$ & $\mathbf{a}$ \\
\hline $\mathrm{N}_{\mathrm{a}}$ & $g m^{-2}$ & 2.0 & \pm 0.2 & a & $2.4 \pm 0.1$ & b & $2.7 \pm 0.3$ & b \\
\hline $\mathrm{Pa}_{\mathrm{a}}$ & $m g m^{-2}$ & & \pm 5 & a & $128 \pm 7$ & b & $104 \pm 14$ & b \\
\hline $\mathrm{N}$ per leaf & $m g$ & 24.5 & \pm 4.4 & $\mathbf{a}$ & $38.8 \pm 10.3$ & a & $11.1 \pm 3.4$ & b \\
\hline$P$ per leaf & $m g$ & 0.71 & \pm 0.14 & $a b$ & $2.06 \pm 0.53$ & a & $0.40 \pm 0.09$ & b \\
\hline $\mathrm{N} / \mathrm{P}$ & & 35.2 & \pm 2.8 & a & $19.9 \pm 1.3$ & b & $27.8 \pm 2.3$ & $a b$ \\
\hline
\end{tabular}


$1000 \mathrm{~m}$

Gas exchange

traits

a) Area-related

$A_{\operatorname{maxTACA}}$

$\mathrm{A}_{\operatorname{maxT} \mathrm{AC} 33}$

$A_{\operatorname{maxT} 25 \mathrm{CA}}$

$\mathrm{A}_{\operatorname{maxT} 25 \mathrm{C} 33}$

$\mathrm{V}_{\text {cmaxTA }}$

$\mathrm{V}_{\text {cmaxT25 }}$

$J_{\max T A}$

$J_{\operatorname{maxT25}}$

$\alpha$

CE

LCP

LSP

$\mathrm{CO}_{2} \mathrm{CP}$

PNUE

PPUE

b) Mass-related

$A_{\text {maxmasstacA }}$

$A_{\text {maxmassTAC33 }}$

$\mathrm{A}_{\text {maxmassT25CA }}$

$\mathrm{A}_{\text {maxmassT25C33 }}$

Dark respiration

$\mathrm{R}_{\text {DTA }}$

$\mathrm{R}_{\mathrm{DT} 25}$

$\delta^{13} \mathrm{C}$

$\begin{array}{llllrlrlll}\mu \mathrm{mol} \mathrm{m} \mathrm{m}^{-2} \mathrm{~s}^{-1} & 8.8 \pm 0.8 & \mathbf{a} & 11.3 \pm 0.6 & \mathbf{b} & 7.2 \pm 0.9 & \mathbf{a} \\ \mu \mathrm{mol} \mathrm{m} \mathrm{m}^{-2} \mathrm{~s}^{-1} & 8.8 \pm 0.8 & \mathbf{a} & 11.5 \pm 0.7 & \mathbf{b} & \pm .9 \pm 0.99 & \mathbf{a b} \\ \mu \mathrm{mol} \mathrm{m} \mathrm{m}^{-2} \mathrm{~s}^{-1} & 9.6 \pm 0.8 & \mathbf{a} & 18.9 \pm 1.0 & \mathbf{b} & 16.3 \pm 2.0 & \mathbf{b} \\ \mu \mathrm{mol} \mathrm{m} \mathrm{m}^{-2} \mathrm{~s}^{-1} & 9.6 \pm 0.8 & \mathbf{a} & 19.0 \pm 1.1 & \mathbf{b} & 18.8 \pm 2.1 & \mathbf{b}\end{array}$

$\mu \mathrm{mol} \mathrm{m}^{-2} \mathrm{~s}^{-1}$

$\mu \mathrm{mol} \mathrm{m} \mathrm{m}^{-2} \mathrm{~s}^{-1}$

$49 \pm$

$49 \pm 4$

$43 \pm 2$

$69 \pm$

a $24 \pm 2$ b

$\mu$ mol electrons $m^{-2} s^{-1}$

$67 \pm$

$84 \pm$

b $80 \pm 3$ b

umol electrons $m^{-2} s^{-1}$

$68 \pm 4$

a $111 \pm 5$

$\mathrm{mol} \mathrm{mol}^{1}$

$0.062 \pm 0.002$

$0.060 \pm 0.002$

a $0.057 \pm 0.003$ a

$48 \pm 1 \quad$ a $33 \pm 3$ b $41 \pm 2$ a

$\mu \mathrm{mol} \mathrm{m}^{-2} \mathrm{~s}^{-1}$

$\mu \mathrm{mol} \mathrm{m} \mathrm{m}^{-2} \mathrm{~s}^{-1}$

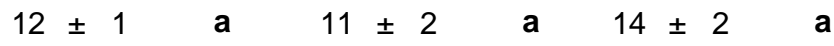

$716 \pm 61 \quad$ ab $924 \pm 60$ a $620 \pm 80$ b

$0.060 \pm 0.005$ ab $0.077 \pm 0.004$ a $0.049 \pm 0.005$ b

$\mu \mathrm{mol} \mathrm{CO}_{2} \mathrm{~mol} \mathrm{~N} \mathrm{~N}^{-1}$

$62.3 \pm 7.4$ ab $67.0 \pm 4$.

a $40.0 \pm 6.3 \quad$ b

$\mathrm{mmol} \mathrm{CO}_{2} \mathrm{~mol} \mathrm{P}^{-1} \mathrm{~s}^{-1}$

$4.7+0.4$

a $2.87 \pm 0.4$

b $2.4 \pm 0.4$ b

$n m o l g^{-1} s^{-1}$

$n m o l g^{-1} s^{-1}$

$n m o l g^{-1} s^{-1}$

$n m o l g^{-1} s^{-1}$

$83 \pm 9$
$83 \pm 9$
$91 \pm 10$
$91 \pm 10$

a

$99 \pm 12$

a

$42 \pm 7$ b

$101 \pm 12$

$50 \pm 8$

a $164 \pm 18$

b $94 \pm 16$ a

$91 \pm 10$

$164 \pm 17$

b $106 \pm 16$

a

$\mu \mathrm{mol} \mathrm{m}^{-2} \mathrm{~s}^{-1}$

$0.75 \pm 0.07$

a $0.62 \pm 0.10$

$0.83 \pm 0.08$

$1.03 \pm 0.15$

a $0.66 \pm 0.07$ a

$\mu \mathrm{mol} \mathrm{m}^{-2} \mathrm{~s}^{-2}$

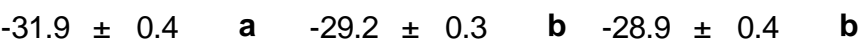




\section{Results}

\section{Elevational change in leaf characteristics and photosynthetic capacity}

Table 2 gives the community means of the three stands for about 30 parameters of photosynthetic capacity (at ambient and standardised low-elevation temperature and $\left[\mathrm{CO}_{2}\right]$ conditions), leaf dark respiration, and foliar morphology and nutrient concentrations. In addition, the species means of $A_{\max }$ at ambient conditions $\left(A_{\operatorname{maxTACA}}\right)$, leaf size, SLA, diameter growth and wood specific gravity of the 40 investigated tree taxa are given in Table A4 in the Appendix. While mean leaf size and SLA showed opposing elevation trends between 1000 and $2000 \mathrm{~m}$ for the 10-16 species from 9-12 families investigated per stand (increase in leaf size, decrease in SLA), a large and statistically significant decrease was observed for both traits between 2000 and $3000 \mathrm{~m}$. Relative stem diameter increment measured in 9-11 species per stand tended to decrease in its community mean from the $1000-\mathrm{m}$ to the 2000-m stand (difference not significant) but remained invariant higher upslope. Our data do not show significant elevational change in the community mean of wood specific gravity, even though the 3000-m stand exhibited the highest mean $(0.56 \mathrm{~g}$ $\mathrm{cm}^{-3}$, Table 2).

The mid-slope peak in leaf size was paralleled by maxima of mass-specific foliar $\mathrm{N}$ and $P$ contents $\left(N_{m}\right.$ and $\left.P_{m}\right)$ and by a minimum of foliar N/P ratio at $2000 \mathrm{~m}$; the 3000-m stand showed the smallest $\mathrm{N}_{\mathrm{m}}$ mean along the transect (difference significant to the 2000-m stand). The area-specific $N$ and $P$ contents $\left(N_{a}\right.$ and $\left.P_{a}\right)$, in contrast, increased from 1000 to $2000 \mathrm{~m}$ and differed not significantly between the 2000-m and 3000-m stands (Table 2). When the six species of Melastomataceae or the four species of Lauraceae in the study region were analysed separately, similar elevational SLA, $N_{m}$ and $P_{m}$ trends appeared as for the whole tree species sample (Fig. 1A-C). 

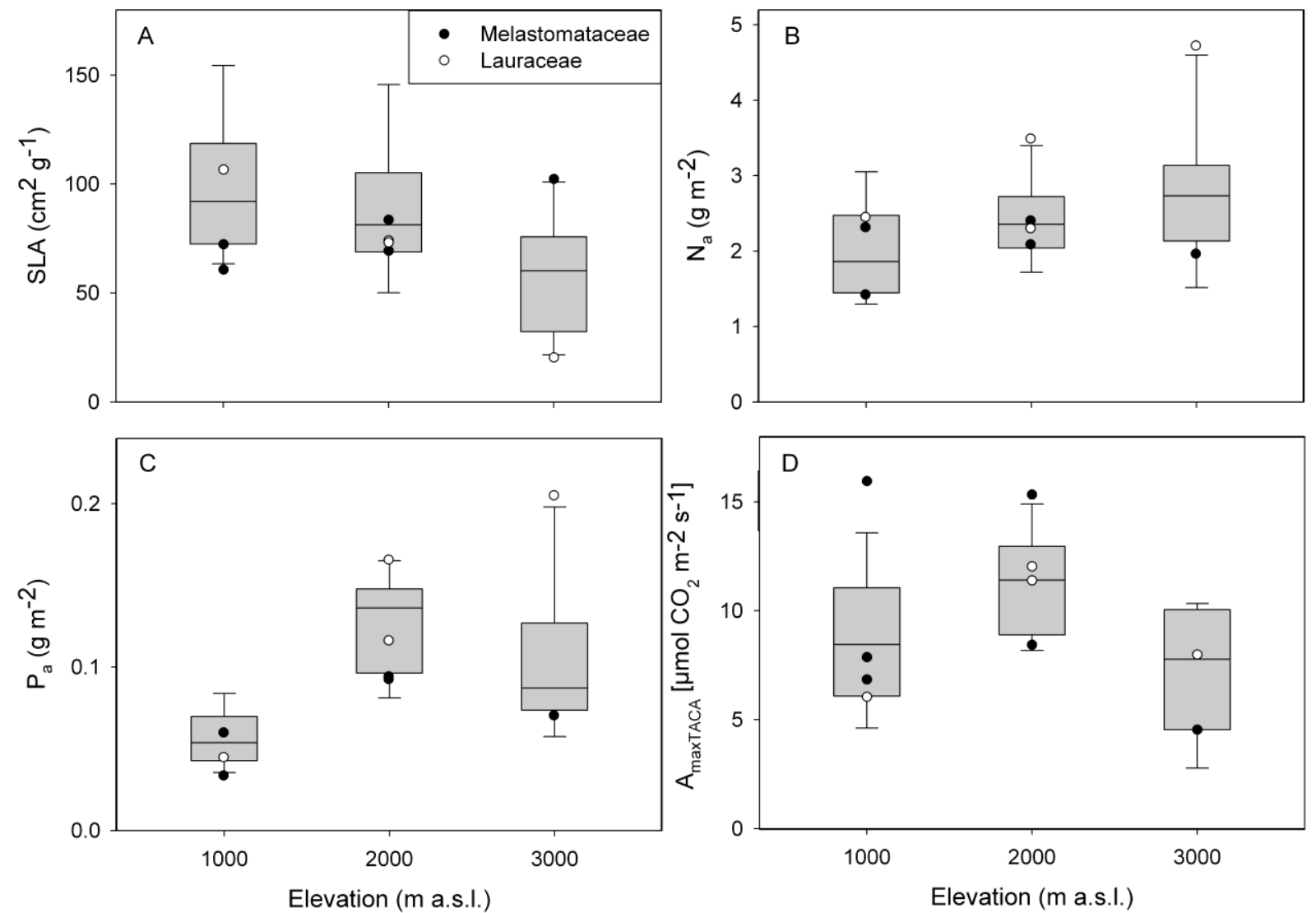

Figure 1. Elevational change in $S L A(A)$, area-based foliar $N\left(N_{a} ; B\right)$, area-based foliar $P\left(P_{a}\right.$; $C)$ and $A_{\text {maxtACA }}(D)$ in the species of Melastomataceae (filled dots) or Lauraceae (circles) in relation to the entire sample studied at $1000 \mathrm{~m}, 2000 \mathrm{~m}$ and $3000 \mathrm{~m}$ elevation (box-whiskerplots with median, 25- and 75-percent quartiles and 90th and 10th percentiles).

The stand means of $A_{\text {maxTACA }}$ increased from 8.8 to $11.3 \mu \mathrm{mol} \mathrm{m} \mathrm{m}^{-2} \mathrm{~s}^{-1}$ between 1000 to $2000 \mathrm{~m}$, but dropped again to $7.2 \mu \mathrm{mol} \mathrm{m} \mathrm{m}^{-1}$ at $3000 \mathrm{~m}$ (both differences significant; Table 2). This pattern was mirrored in the separate analysis of the Melastomataceae and Lauraceae taxa (Fig. 1D). When $A_{\max }$ was standardised to low-elevation temperature $\left(25^{\circ} \mathrm{C}\right)$ and $\left[\mathrm{CO}_{2}\right](33 \mathrm{~Pa})$ conditions, which characterise the sun-canopy conditions in the 1000-m stand around noon, photosynthetic capacity was higher than $A_{\text {maxTACA }}$ by $0.2,7.6$ and $7.7 \mu \mathrm{mol} \mathrm{CO}_{2} \mathrm{~m}^{-2} \mathrm{~s}^{-1}$, when local $\left[\mathrm{CO}_{2}\right]$ was increased to 33 $\mathrm{Pa}$, the local temperature was adjusted to $25^{\circ} \mathrm{C}$, or both adjustments were applied, respectively (Table 2). At $3000 \mathrm{~m}$, the adaptive increase in $A_{\max }$ relative to the $1000-\mathrm{m}$ 
conditions was even larger with 1.7 ( $\left.A_{\operatorname{maxTAC} 33}\right), 9.1\left(A_{\operatorname{maxT25CA}}\right)$ and $11.6 \mu \mathrm{mol} \mathrm{m} \mathrm{m}^{-2} \mathrm{~s}^{-1}$ $\left(A_{\max T 25 \mathrm{C} 33}\right)$ difference between $A_{\max }$ at ambient and simulated low-elevation conditions (Fig. 2 and Table 2). Thus, we found a more pronounced adaptation of $A_{\max }$ to the temperature reduction than to lowered $\left[\mathrm{CO}_{2}\right]$.

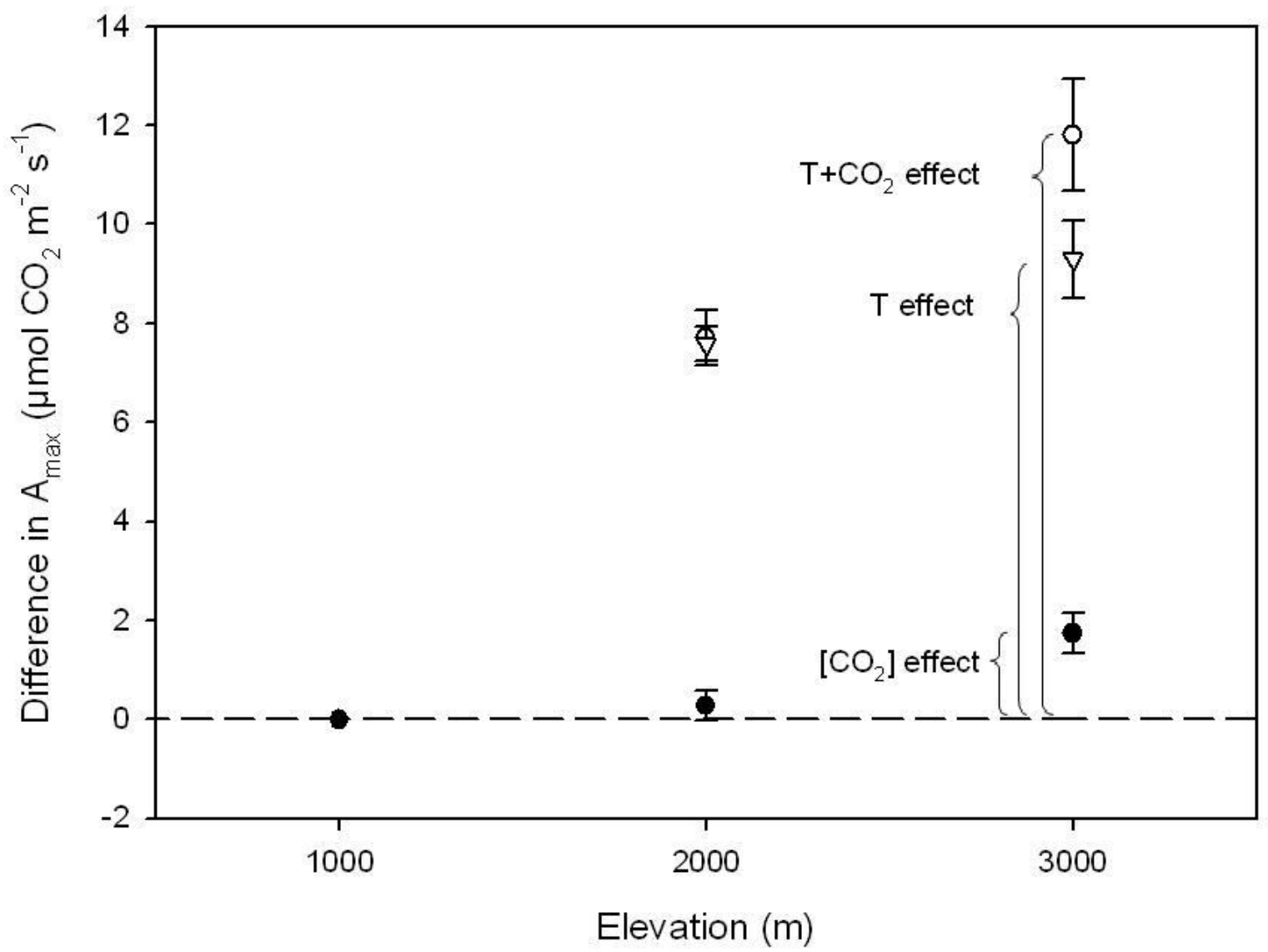

Figure 2. Difference between $A_{\operatorname{maxtACA}}$ (ambient $T$ and $\left[\mathrm{CO}_{2}\right]$ conditions) and $A_{\max }$ standardised to low-elevation temperature $\left(25^{\circ} \mathrm{C}\right)$ and $\left[\mathrm{CO}_{2}\right](33 \mathrm{~Pa})$ in the stands at 2000 and $3000 \mathrm{~m}$. The dotted line indicates the level of $A_{\max T A C A}$. Means $\pm S E$ of $16(2000 \mathrm{~m})$ and 10 species $(3000 \mathrm{~m})$ per stand.

The pronounced temperature adaptation of $A_{\max }$ is also evident from a comparison of maximum carboxylation rate $\left(\mathrm{V}_{\mathrm{cmax}}\right)$ or maximum electron transport rate $\left(\mathrm{J}_{\max }\right)$ 
measured either at ambient or standardised to low-elevation temperature $\left(25^{\circ} \mathrm{C}\right)$. $\mathrm{V}_{\mathrm{cmax}}$ dropped significantly from 2000 to $3000 \mathrm{~m}$ when measured at ambient temperatures (Table 2). However, when $\mathrm{V}_{\mathrm{cmax}}$ was corrected to $25{ }^{\circ} \mathrm{C}\left(\mathrm{V}_{\mathrm{cmax} \text { T25 }}\right)$ at $3000 \mathrm{~m}$, maximum carboxylation rate increased to the same level as had been measured at $25{ }^{\circ} \mathrm{C}$ at $1000 \mathrm{~m}$. In the $2000 \mathrm{~m}$ stand, the $\mathrm{V}_{\mathrm{cmax}}$ mean increased to a rate significantly higher than the rates of the $1000 \mathrm{~m}$ and $3000 \mathrm{~m}$ stands when calculated for $25^{\circ} \mathrm{C}$. $\mathrm{J}_{\max }$ measured at ambient temperature increased significantly from the $1000 \mathrm{~m}$ to $2000 \mathrm{~m}$ stand. When the $\mathrm{J}_{\max }$ values were calculated for $25^{\circ} \mathrm{C}$, we found a significant increase from $1000 \mathrm{~m}$ to $2000 \mathrm{~m}$ and from $2000 \mathrm{~m}$ to $3000 \mathrm{~m}$ (Table 2).

Only minor (and mostly non-significant) elevational changes were detected for several parameters characterising the efficiency of light harvesting and carboxylation in tree sun leaves: quantum yield and the light compensation point of net photosynthesis showed no elevation trend in their community means between 1000 and $3000 \mathrm{~m}$. Carboxylation efficiency (CE, the initial slope of the $A / c_{i}$ curve) was not significantly different in its stand means at 1000 and $3000 \mathrm{~m}$ but peaked at $2000 \mathrm{~m}$ (difference significant; Table 2).

The shape of the light response curves was similar at the three elevations (averaged over 10-16 species) but the $A / Q$ curves reflected the significantly higher $A_{\max \text { TACA }}$ mean in the 2000-m stand which likely is related to the relatively high foliar $\mathrm{N}$ and $\mathrm{P}$ concentrations (Fig. 3A). The $\mathrm{A} / \mathrm{c}_{\mathrm{i}}$ curves, averaged over all species of a stand, exhibited similar shapes and initial slopes (CE) at 1000 and $2000 \mathrm{~m}$ elevation. Yet, the mean $A / c_{i}$ curve for the 3000-m stand showed a steeper increase at high $c_{i-}$ concentrations ( $>500 \mu \mathrm{mol} \mathrm{CO} \mathrm{mol} \mathrm{air}^{-1}$ ) than the 1000- and 2000-m curves (Fig. 3B). 

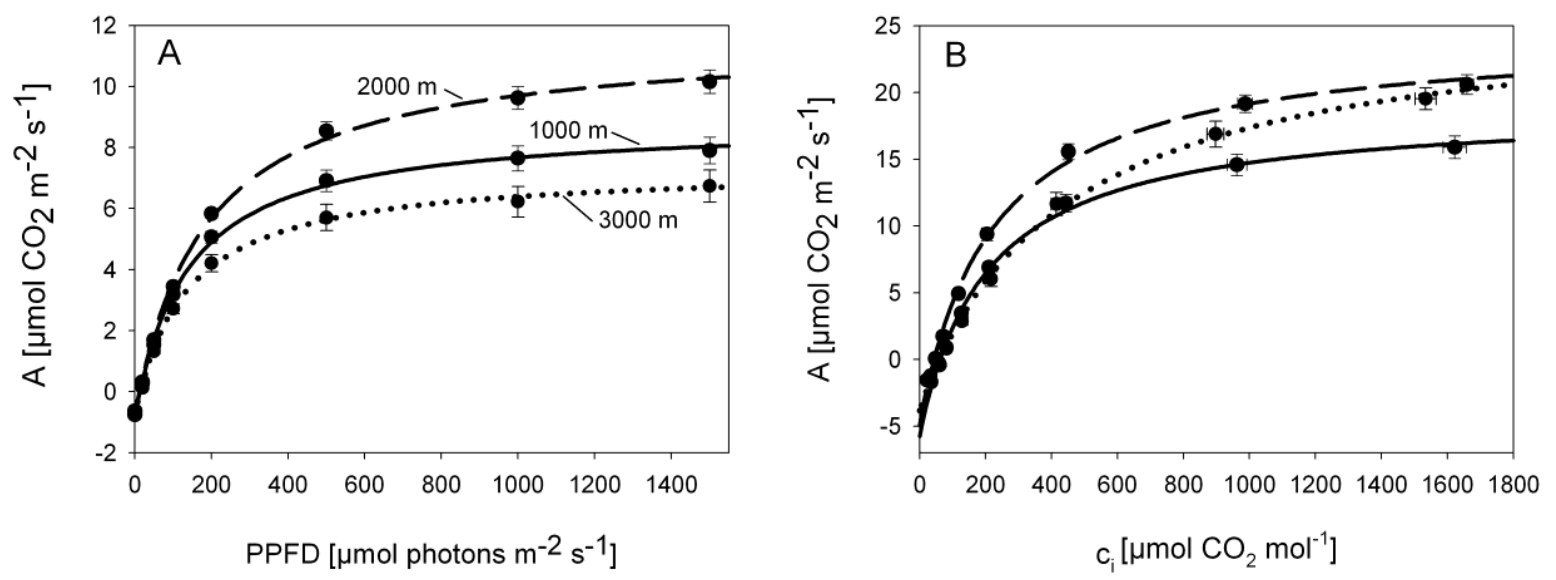

Figure 3. Light $(A)$ and $\mathrm{CO}_{2}$ response curves $(B)$ of net photosynthesis averaged over all sampled species for the stands at 1000, 2000, and $3000 \mathrm{~m}$ a.s.I. in southern Ecuador. Error bars give SE for 10 to 16 tree species examined with each three fully sun-exposed leaves measured per species.

The stand-level means of instantaneous photosynthetic $N$ or $P$ use efficiencies ( $A_{\max \text { TACA }}$ per unit foliar $\mathrm{N}$ or $\mathrm{P}$ ) were significantly smaller at $3000 \mathrm{~m}$ than at lower elevation (PNUE: difference significant to the 2000-m stand, PPUE: difference significant to the $1000-\mathrm{m}$ stand).

Photosynthetic capacity expressed per leaf mass $\left(A_{\text {maxmass }}\right)$ was found to be highest at intermediate elevation (2000 m: mean of $99 \mathrm{nmol} \mathrm{CO} 2 \mathrm{~g} \mathrm{~g} \mathrm{~s}^{-1}$ ) and lowest at 3000 $\mathrm{m}\left(42 \mathrm{nmol} \mathrm{g}^{-1} \mathrm{~s}^{-1}\right.$, difference significant to 1000 and $2000 \mathrm{~m}$; Table 2), which broadly resembles the elevational patterns found for area-specific $A_{\max }$. Standardised (lowelevation) temperature $\left(25^{\circ} \mathrm{C}\right)$ and $\left[\mathrm{CO}_{2}\right]$ conditions $(33 \mathrm{~Pa})$ led to large increases in $A_{\text {maxmass }}$ at 2000 and $3000 \mathrm{~m}$, though to a lesser extent than in $A_{\text {maxarea }}$ due to the elevational SLA decrease.

Leaf dark respiration $\left(R_{D}\right)$ at ambient temperature was similar at all three elevations. When $R_{D}$ was corrected to $25{ }^{\circ} \mathrm{C}$, respiration rate increased along the slope from $0.83(1000 \mathrm{~m})$ to $1.48 \mu \mathrm{mol} \mathrm{CO} \mathrm{m}^{-2} \mathrm{~s}^{-1}(3000 \mathrm{~m})$. 
The stand means of sun-leaf $\delta^{13} \mathrm{C}$ decreased significantly from $-31.9 \%$ at $1000 \mathrm{~m}$ to $-29.2 \%$ at $2000 \mathrm{~m}$ and $-28.9 \%$ at $3000 \mathrm{~m}$ (Table 2).

Table 3. Results of linear correlation analyses after Pearson between five gas exchange parameters and several biophysical and biotic variables with a possible influence on photosynthesis and leaf dark respiration $\left(R_{D}\right)$. Given are the $R$ and $P$ values. Significant relationships $(P<0.05)$ in bold. All photosynthetic parameters are scaled to leaf area except for $A_{\text {maxmassTACA. }}$

\begin{tabular}{|c|c|c|c|c|c|}
\hline & $A_{\operatorname{maxTACA}}$ & $A_{\operatorname{maxTAC} 33}$ & $A_{\operatorname{maxT25C33}}$ & $\mathbf{A}_{\text {maxmasstACA }}$ & $\mathbf{R}_{\mathrm{DTA}}$ \\
\hline $\mathrm{P}_{\mathrm{a}}$ & $\begin{array}{l}R=0.412 \\
p<0.001\end{array}$ & $\begin{array}{l}R=0.460 \\
P=0.003\end{array}$ & $\begin{array}{c}R=0.591 \\
P<0.0001\end{array}$ & $\begin{array}{l}R=0.085 \\
P=0.608\end{array}$ & $\begin{array}{l}R=0.068 \\
P=0.682\end{array}$ \\
\hline$P_{m}$ & $\begin{array}{l}R=0.411 \\
p<0.001\end{array}$ & $\begin{array}{l}R=0.294 \\
P=0.065\end{array}$ & $\begin{array}{l}R=0.238 \\
P=0.140\end{array}$ & $\begin{array}{c}R=0.759 \\
P<0.0001\end{array}$ & $\begin{array}{l}R=0.285 \\
P=0.071\end{array}$ \\
\hline $\mathrm{N}_{\mathrm{a}}$ & $\begin{array}{l}R=0.179 \\
P=0.277\end{array}$ & $\begin{array}{l}R=0.278 \\
P=0.091\end{array}$ & $\begin{array}{l}R=0.409 \\
P=0.011\end{array}$ & $\begin{aligned} R & =-0.243 \\
P & =0.136\end{aligned}$ & $\begin{aligned} R & =-0.221 \\
P & =0.176\end{aligned}$ \\
\hline $\mathrm{N}_{\mathrm{m}}$ & $\begin{array}{l}R=0.172 \\
P=0.282\end{array}$ & $\begin{array}{l}R=0.063 \\
P=0.699\end{array}$ & $\begin{array}{c}R=-0.084 \\
P=0.606\end{array}$ & $\begin{array}{l}R=0.621 \\
P<0.0001\end{array}$ & $\begin{array}{l}R=0.125 \\
P=0.436\end{array}$ \\
\hline SLA & $\begin{array}{l}R=0.029 \\
P=0.857\end{array}$ & $\begin{array}{c}R=-0.172 \\
P=0.294\end{array}$ & $\begin{array}{c}R=-0.383 \\
P=0.016\end{array}$ & $\begin{array}{c}R=0.737 \\
P<0.0001\end{array}$ & $\begin{array}{l}R=0.267 \\
P=0.096\end{array}$ \\
\hline Leaf size & $\begin{array}{l}R=0.294 \\
P=0.069\end{array}$ & $\begin{array}{l}R=0.197 \\
P=0.235\end{array}$ & $\begin{array}{c}R=-0.022 \\
P=0.894\end{array}$ & $\begin{array}{l}R=0.313 \\
P=0.053\end{array}$ & $\begin{array}{r}R=-0.020 \\
P=0.904\end{array}$ \\
\hline WSG & $\begin{aligned} R & =-0.324 \\
P & =0.041\end{aligned}$ & $\begin{aligned} R & =-0.338 \\
P & =0.035\end{aligned}$ & $\begin{aligned} R & =-0.130 \\
P & =0.431\end{aligned}$ & $\begin{array}{c}R=-0.413 \\
P=0.010\end{array}$ & $\begin{aligned} R & =-0.167 \\
P & =0.304\end{aligned}$ \\
\hline $\begin{array}{l}\text { DBH } \\
\text { increment }\end{array}$ & $\begin{array}{c}R=-0.042 \\
P=0.828\end{array}$ & $\begin{array}{c}R=-0.141 \\
P=0.467\end{array}$ & $\begin{array}{c}R=-0.216 \\
P=0.260\end{array}$ & $\begin{array}{l}R=0.277 \\
P=0.153\end{array}$ & $\begin{array}{l}R=0.062 \\
P=0.750\end{array}$ \\
\hline
\end{tabular}


Controlling factors of photosynthetic capacity

Of the eight foliar and growth-related traits analysed in simple regressions, leaf phosphorus content was found to have the largest influence on area-specific $A_{\max }$ in the 40-species sample. $P_{a}$ (and also $P_{m}$ ) correlated significantly with $A_{\max }$ at ambient and standardised conditions while the $\mathrm{N}$ influence was only of secondary importance (significant effect of $\mathrm{N}_{\mathrm{a}}$ only on $\mathrm{A}_{\max T 25 \mathrm{C} 33}$ but not on $\mathrm{A}_{\max \text { TACA }}$, Table 3).
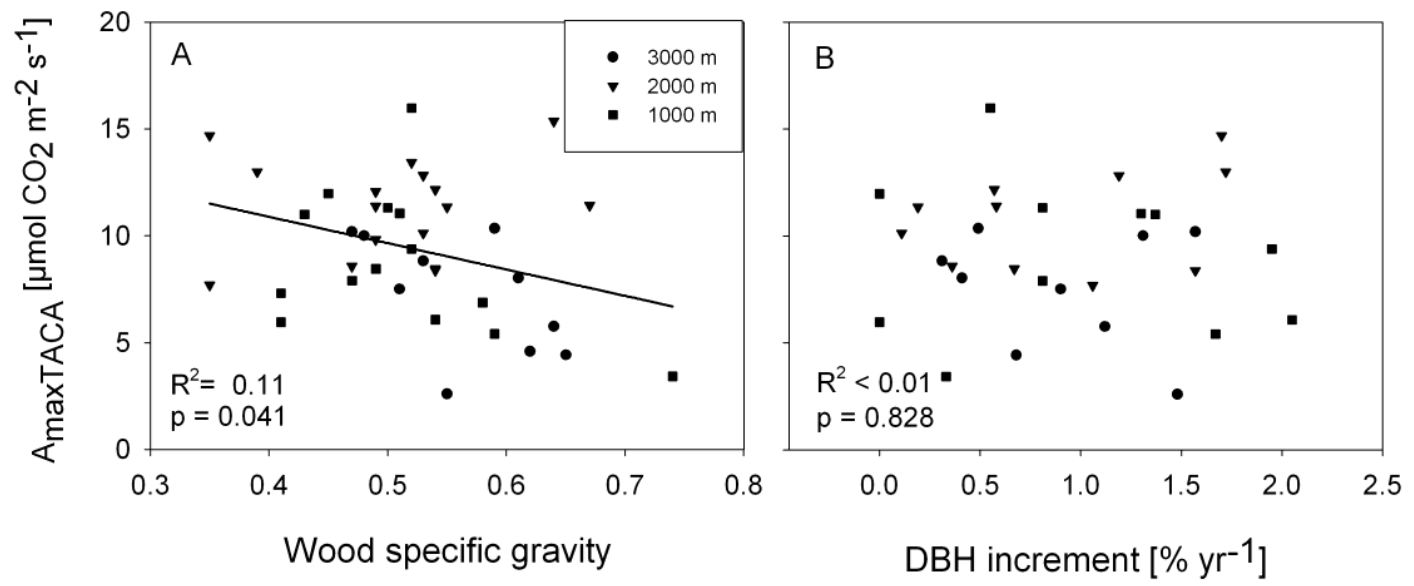

Figure 4. Dependence of light-saturated net photosynthesis at ambient temperature and $\left[\mathrm{CO}_{2}\right]\left(A_{\text {maxTACA }}\right)$ of the 40 investigated species on $\left.A\right)$ wood specific gravity and $B$ ) relative stem diameter increment rate.

We found a significant negative relationship between $A_{\max }$ and SLA (only in $A_{\max 225 C 33}$, not in $\left.A_{\operatorname{maxTACA}}\right)$ in our sample. Further, $A_{\operatorname{maxTACA}}$ increased with decreasing wood specific gravity of the stem, while no relation existed with relative stem diameter increment (Fig. 4A and B, and Table 3). As expected, the relationships between photosynthetic parameters and foliar and growth-related traits were much weaker when the analysis was conducted separately for the three stands (most relationships not significant; results not shown). 
Leaf mass-specific photosynthetic capacity ( $\left.A_{\text {maxmassTACA }}\right)$ showed very tight relationships to both $P_{m}(R=0.76)$ and $N_{m}(R=0.62)$ but not to foliar $P$ and $N$ per area. SLA and leaf size had a positive, wood specific gravity a negative influence on $A_{\text {maxmasstACA. }}$ Leaf dark respiration was not related to any of the eight foliar and growth-related traits, neither when measured at ambient nor at standard $\left(25^{\circ} \mathrm{C}\right)$ temperature (Table 3).

A multiple regression analysis confirmed these results. For $A_{\operatorname{maxTACA}}$, it indicated that $P_{m}$ and SLA (in the order of significance) were the most important determinants of photosynthetic capacity in the 40-species sample while temperature, $\left[\mathrm{CO}_{2}\right]$ and wood specific gravity were only of secondary importance (only significant in factor combinations), and foliar nitrogen was not significant at all (Table 4). Leaf dark respiration was mainly influenced by foliar $P$ but not $N$, similar to photosynthetic capacity. A significant temperature effect on respiration was not detected across the elevation gradient. 
Table 4. Results of multiple regression analyses on the effects of the seven variables listed in Table 1 on photosynthetic capacity $\left(A_{\text {maxtACA }}\right)$ and leaf dark respiration $\left(R_{D}\right)$. Two models are presented in which either $\left[\mathrm{CO}_{2}\right]$ (a) or $\mathrm{T}$ (b) is excluded as variable due to their relatedness (see Table 1). Presented are the final models which were identified according to minimum AIC scores. The AIC values of the final models were 187.8 ( $\left.A_{\text {maxTACA }}(a)\right), 186.9$ $\left(A_{\operatorname{maxTACA}}(b)\right)$ and $20.3\left(R_{D}\right)$. The final models include only the variables with largest influence on the dependent variable.

\begin{tabular}{|c|c|c|c|c|c|c|}
\hline $\begin{array}{l}\text { Dependent } \\
\text { variable }\end{array}$ & & $\begin{array}{l}\text { Model } R^{2} \\
\text { (adjusted) }\end{array}$ & $\begin{array}{l}\text { Independent } \\
\text { variable }\end{array}$ & $\begin{array}{l}\text { Parameter } \\
\text { estimate }\end{array}$ & $\begin{array}{l}\text { Partial regression } \\
\text { coefficient }\end{array}$ & $p$-value \\
\hline \multirow[t]{8}{*}{$A_{\max T A C A}$} & (a) & 0.28 & $\mathrm{P}_{\mathrm{m}}$ & 4.35 & 0.26 & 0.001 \\
\hline & & & SLA & -0.04 & -0.03 & 0.035 \\
\hline & & & $T$ & 0.24 & 0.03 & 0.189 \\
\hline & & & WSG & -7.13 & 0.06 & 0.197 \\
\hline & (b) & 0.30 & $P_{m}$ & 4.30 & 0.26 & 0.001 \\
\hline & & & SLA & -0.04 & -0.04 & 0.024 \\
\hline & & & $\mathrm{CO}_{2}$ & 0.34 & 0.04 & 0.116 \\
\hline & & & WSG & -7.17 & 0.06 & 0.184 \\
\hline \multirow[t]{2}{*}{$\mathrm{R}_{\mathrm{D}}$} & (a) & 0.10 & $\mathrm{P}_{\mathrm{m}}$ & 0.29 & 0.02 & 0.021 \\
\hline & & & $\mathrm{P}_{\mathrm{a}}$ & -1.23 & -0.01 & 0.356 \\
\hline
\end{tabular}

\section{Discussion}

\section{Photosynthetic performance of high-elevation trees}

In the trees growing at 2000 and $3000 \mathrm{~m}$, we found a considerable capacity to adapt to the less favourable temperature and $\left[\mathrm{CO}_{2}\right]$ conditions at high elevations by morphological or physiological modification, when referenced against the trees at $1000 \mathrm{~m}$. This is evidenced by the comparison of photosynthetic capacity measured under ambient conditions and standardised to (low-elevation) $\left[\mathrm{CO}_{2}\right]$ and temperature levels. The photosynthetic capacity was on average higher by 2 and $24 \%$ in the 2000-m and 3000-m stands, when the carbon dioxide concentration was increased from ambient to low-elevation conditions (33 Pa). The percental up-regulation of $A_{\max }$ was smaller than the relative decrease in $\mathrm{CO}_{2}$ partial pressure ( $\left.30 \%\right)$ from 1000 to 
$3000 \mathrm{~m}$. The homeostatic $A_{\max }$ response was much larger to the $3 \mathrm{~K}$ - or $10 \mathrm{~K}$ temperature decrease from 1000 to 2000 or $3000 \mathrm{~m}$ than to the $\left[\mathrm{CO}_{2}\right]$ decrease: $A_{\max }$ increased by 68 and $126 \%$ at 2000 and 3000 m, respectively, when photosynthetic capacity was calculated for the low-elevation reference temperature of $25^{\circ} \mathrm{C}$ instead of ambient temperature. The effectiveness of the homeostatic adjustment of $A_{\max }$ to the high-elevation environment is shown by the multiple regression analysis which revealed $A_{\max T A C A}$ to be primarily controlled by foliar $P$ and SLA in the 40-species sample while both the temperature and $\left[\mathrm{CO}_{2}\right]$ influences were small.

Homeostatic modification of $A_{\max }$ to the high-elevation environment may include leaf morphological change (increased leaf thickness with more layers of palisade mesophyll cells and a higher $\mathrm{N}$ content per leaf area; e.g. Benecke et al. 1981; Körner 2003; Wieser et al. 2012) but may also cover physiological modifications. Morecroft et al. (1992) and Cordell et al. (1999) found in Scotland and Hawai'i elevational increases in the carboxylation efficiency (CE) of trees and herbaceous plants. Such a response was not detected in the Ecuadorian transect, where the stand-level CE mean peaked at $2000 \mathrm{~m}$, thus contradicting our second hypothesis. The mid-slope CE maximum coincided with the conspicuous maximum in foliar $\mathrm{P}$ concentration at this elevation pointing to a major influence of foliar $P$ on photosynthetic capacity.

Maximum carboxylation rate per leaf area $\left(\mathrm{V}_{\mathrm{cmax}}\right)$ did not decrease from 1000 to 3000 $\mathrm{m}$ when calculated for $25{ }^{\circ} \mathrm{C}$, but it peaked at $2000 \mathrm{~m}$ probably reflecting the elevational change in $\mathrm{P}_{\mathrm{a}}$ along the transect. Our average values of $49 \mu \mathrm{mol} \mathrm{m} \mathrm{m}^{-2} \mathrm{~s}^{-1}$ $(1000 \mathrm{~m})$ and $52 \mu \mathrm{mol} \mathrm{m} \mathrm{m}^{-2} \mathrm{~s}^{-1}(3000 \mathrm{~m})$ are very similar to the $\mathrm{V}_{\mathrm{cmax}}$ means found by Wullschleger (1993) (51 $\square 31 \mu_{\mathrm{mol} \mathrm{m}}^{-2} \mathrm{~s}^{-1}$ ) and the literature survey of Van de Weg et al. (2012) for tropical rainforests. At ambient temperatures, however, $V_{c m a x}$ decreased in our transect between 1000 and $3000 \mathrm{~m}$ to the half pointing to a large temperature effect on rubisco activity at higher elevations (temperature difference: 7 $K)$. The large decrease in mass-related $A_{\max }$ and also in photosynthetic $\mathrm{N}$ and $\mathrm{P}$ use efficiency with increasing elevation above $2000 \mathrm{~m}$ seems to support this interpretation. 
Other than $\mathrm{V}_{\text {cmaxT25, }}$, the maximum rate of electron transport $\left(\mathrm{J}_{\max }\right)$ significantly increased with elevation when standardised to $25^{\circ} \mathrm{C}$; the elevational increase from 1000 to 2000 and $3000 \mathrm{~m}$ persisted when $J_{\max }$ was measured at ambient temperature. Van de Weg et al. (2012) also found indications for preferential investment in $\mathrm{J}_{\max }$ as compared to $\mathrm{V}_{\text {cmax }}$ capacity in the canopy leaves of a Peruvian cloud forest at $3000 \mathrm{~m}$ a.s.l. They assumed this to be either a response to the reduced light availability at this elevation indicating a need for additional investment into electron transport capacity, or a consequence of the prevailing low vpd levels which promote higher leaf conductances and elevated average $c_{i}$ values. This would reduce the need to invest in additional carboxylation capacity in this moist low-light environment. The high annual mean air humidity (>95\%) at $3000 \mathrm{~m}$ (see Table A1 in the Appendix) and the high cloud frequency throughout the year at $3000 \mathrm{~m}$ in the Ecuadorian transect (Bendix et al. 2008) seem to support both interpretations.

The widely observed tendency of reduced discrimination against ${ }^{13} \mathrm{CO}_{2}$ in the photosynthesis of high-elevation plants (Körner et al. 1988; Körner et al. 1991) is also evident from our data. Since carboxylation efficiency was not reduced at the highest elevation, this factor cannot explain the $\delta^{13} \mathrm{C}$ increase in our transect. We assume that the effect is mainly caused by an elevational increase in the resistance to $\mathrm{CO}_{2}$ diffusion from the intercellular spaces to the chloroplasts (Terashima et al. 1995) which would be plausible from the SLA decrease. A higher leaf internal resistance would decrease the $c_{i} / c_{a}$ ratio leading to a less negative $\delta^{13} \mathrm{C}$ signature. A lowered leaf-internal conductivity for $\mathrm{CO}_{2}$ in thicker leaves could also explain, together with a putative temperature effect on photosynthetic capacity (and perhaps $P$ limitation), the observed elevational reduction in $A_{\max }$ from 2000 to $3000 \mathrm{~m}$.

It is not surprising that we did not find a relationship between $A_{\max }$ and wood productivity (annual relative diameter increment) across our species sample because leaf area, radiation interception and $\mathrm{C}$ allocation patterns may be more important determinants of wood growth rate than sun leaf photosynthetic capacity (Farmer 1980; Pallardy 2008). This implies that the negative relation found between $A_{\max }$ and wood specific gravity (WSG) cannot be explained by a causal relationship between 78 
lower growth rate and reduced carbon demand in trees with high WSG. Rather, WSG, SLA and $A_{\max }$ might indirectly interact through plant nitrogen and/or phosphorus status or via WSG effects on hydraulic conductance and plant water status.

Our leaf dark respiration data indicate that the temperature decrease by about $13 \mathrm{~K}$ along the transect was fully compensated by a homeostatic response of leaf mitochondrial activity because we did not find significant differences between the area-related $R_{D}$ means of the $1000 \mathrm{~m}$ - and the $3000 \mathrm{~m}$-stands. Furthermore, temperature was not identified as a variable with a significant influence on leaf dark respiration in the multiple regression analysis. This finding is in agreement with earlier respiration studies which also observed a full or near-complete compensation of the effects of temperature reduction in high-elevation trees and herbaceous when compared to low-elevation plants (e.g. Larigauderie and Körner 1995; Atkin e al. 2000). Much of the apparent 'up-regulation' of respiratory activity per leaf area is explained by the large increase (by $80 \%$ ) in leaf mass per area between 1000 and $3000 \mathrm{~m}$ elevation, i.e. by morphological and not physiological adaptation to the highelevation environment. This explanation is in agreement with results obtained by Cavaleri et al. (2008) in a lowland rainforest who found much of the within-canopy variation in $R_{D}$ being caused by variation in leaf morphology. An unexpected finding was the dominant effect of $\mathrm{P}_{\mathrm{a}}$ on area-related $\mathrm{R}_{\mathrm{D}}$ in our species sample and the insignificant influence of foliar N. This relationship is best explained by our finding of a dominant $P$ influence on photosynthetic capacity which should affect respiration through the close association between leaf respiratory activity and the rate of export of photosynthates from assimilating leaves.

In order to test for the influence of phylogenetic signal on the observed patterns of elevational change in leaf morphology and physiology (Losos 2008; Weber and Agrawal 2012), we examined whether closely related tree species within the families Melastomataceae and Lauraceae, two relatively abundant families with species at all elevations, differed in their trait patterns along the slope systematically from the rest of the species with more distant or no phylogenetic relatedness. From the observation that the elevational trends for $A_{\max T A C A}$ SLA, $N_{a}$ and $P_{a}$ were similar for 
the phylogenetically-related and unrelated species groups, it is unlikely that the observed elevational patterns are partly caused by phylogenetic niche conservatism (PNC). PNC would imply that related species show more similar photosynthetic properties along the slope than would be expected from a null model.

\section{Influence of $P$ and $N$ nutrition on the photosynthetic capacity at high elevations}

Our gas exchange measurements in 40 tree species did not reveal a significant elevational trend in $A_{\max }$ under ambient conditions (means of $8.8 \mathrm{vs} .7 .2 \mu \mathrm{mol} \mathrm{m} \mathrm{m}^{-2} \mathrm{~s}^{-1}$ at 1000 and $3000 \mathrm{~m}$ ), but a significantly higher stand mean at $2000 \mathrm{~m}$. Some evidence suggests that this mid-slope $A_{\max }$ peak might be caused by the patterns of soil availability of $P$ in this transect that seem to have a significant influence on the photosynthetic capacity of the trees.

From global surveys of the nutrient status of montane and alpine plants, it was concluded that nutrient shortage is limiting plant growth at high elevations only exceptionally (Körner 2003; Wieser et al. 2012), as for example at the alpine tree line in Colorado with assumed $P$ limitation (Holtmeier and Broll 1992). Körner (2003) concluded for alpine herbaceous plants that they typically have higher $\mathrm{N}$ contents per leaf area than their relatives in the lowland which makes $\mathrm{N}$ limitation of growth and photosynthesis unlikely. However, extrapolation from the $\mathrm{N}$ and $\mathrm{P}$ status of alpine herbaceous plants to high-elevation trees is not feasible because forests generally have a higher nutrient demand than herbaceous vegetation. This is underpinned by the generally increasing foliar $\mathrm{N}$ concentrations with elevation in herbs (Körner 2003) while the foliar $N_{m}$ values of tropical trees seem to decrease with elevation (see below).

In tropical trees, both foliar $\mathrm{N}$ and $\mathrm{P}$ contents per area $\left(\mathrm{N}_{\mathrm{a}}\right.$ and $\left.\mathrm{P}_{\mathrm{a}}\right)$ have been found to increase with elevation as a consequence of the general decrease in SLA (e.g. in Hawaiian and Bornean mountain forests, Cordell et al. 1999; Hikosaka et al. 2002). In support of our first hypothesis, our data from 40 Ecuadorian mountain forest species 80 
show a $\mathrm{N}_{\mathrm{a}}$ increase by about $30 \%$ between 1000 and $3000 \mathrm{~m}$, while Van de Weg et al. (2009) observed only a slight, but non-significant, $\mathrm{N}_{\mathrm{a}}$ increase in the Peruvian Andes. Less information is available about elevational trends in foliar $\mathrm{P}$ per area in tropical trees. Van de Weg et al. (2009) reported no significant elevational change in $\mathrm{P}_{\mathrm{a}}$ in the Peruvian Andes. As predicted in our first hypothesis, the stand mean of $\mathrm{P}_{\mathrm{a}}$ nearly doubled in our transect from 57 to $104 \mathrm{mg} \mathrm{m}^{-2}$ between 1000 and $3000 \mathrm{~m}$ due to the large elevational SLA decrease. Thus, both $N_{a}$ and $P_{a}$ should principally support moderate to high photosynthetic activities per leaf area in the Ecuadorian high-elevation forests.

A different picture emerges when mass-specific instead of area-specific $N$ and $P$ contents are examined. While conifers at temperate alpine tree lines often have similar or even higher $\mathrm{N}$ concentrations per unit needle dry mass than trees at lower elevation (e.g. Richardson et al. 2001; Birmann and Körner 2009), this seems not to be the case in tropical trees. By summarising the existing information on tropical elevation transects, Tanner et al. (1998) and Benner et al. (2010) in most cases found decreases in $\mathrm{N}_{m}$ and $\mathrm{P}_{\mathrm{m}}$ with elevation. However, exceptions from this rule do exist. For example, no significant trend in the $\mathrm{N}_{\mathrm{m}}$ stand mean was found in a mountain forest transect in eastern Ecuador between 1000 and $2000 \mathrm{~m}$ a.s.l. (Wagner, Homeier \& Leuschner, unpubl. data). Our data from southern Ecuador show a significant $\mathrm{N}_{\mathrm{m}}$ decrease only at higher elevations (by 30\% from 2000 to $3000 \mathrm{~m}$ ) but not in the lower transect section which partly contradicts our hypothesis. This reduction relates to the decrease in $\mathrm{N}$ supply rates with increasing elevation in the Ecuadorian transect (Wolf et al. 2011). From the contrasting $N_{m}$ and $P_{m}$ gradients observed in different tropical mountains, it appears that the specific geological and soil fertility patterns have a considerable influence on the foliar nutrient status of tropical trees which could affect the physiology of mountain forest trees.

When regressing the investigated climatic and biotic parameters on photosynthetic capacity, we obtained three surprising results. First, neither temperature nor atmospheric $\mathrm{CO}_{2}$ concentration were identified as significant influencing factors which indicates that selection has acted to reduce differences in the photosynthetic 
capacity of species growing along the temperature and $\left[\mathrm{CO}_{2}\right]$ gradient along the slope. Second, foliar $P$ concentration $\left(P_{m}\right)$ was identified as the most important factor controlling $A_{\max }$ in the 40-species sample. This is surprising because it seems to show a large influence of nutrient availability on the photosynthetic capacity of these tropical mountain forest trees and it further indicates that $P$ is much more relevant than $\mathrm{N}$, as the nitrogen effect $\left(\mathrm{N}_{\mathrm{a}}\right.$ or $\mathrm{N}_{\mathrm{m}}$ ) was insignificant. This is supported by the mid-slope peak in area-related foliar $P$ in our transect with foliar $P$ being the environmental factor coinciding best with the conspicuous mid-slope $A_{\max }$ peak. Finally, it was unexpected that $P_{m}$ and not $P_{a}$ was the dominant factor because the dependent variable was area-related $A_{\max }$. A direct effect of low foliar $P$ on $A_{\max }$ might be caused by low concentrations of rubisco and other photosynthetic enzymes or feedback inhibition due to slow growth and low $P_{i}$ concentrations in the cytosol (Lambers et al. 2008).

However, $\mathrm{N}$ availability might also influence the productivity of the Ecuadorian mountain forests. Several elevational trends reported in our study suggest that increasing $N$ (perhaps together with $P$ ) shortage toward the highest elevations are negatively affecting forest productivity through indirect influences on leaf size, stand leaf area and tree carbon allocation patterns. First, the total amount of $\mathrm{N}$ and $\mathrm{P}$ allocated to stand leaf biomass is more than $60 \%$ smaller at $3000 \mathrm{~m}$ than at $1000 \mathrm{~m}$ in the transect, which relates to a reduction in LAI from 6.0 to 2.2. Second, the mean amounts of $\mathrm{N}$ and $\mathrm{P}$ invested in the construction of a leaf decrease from 25 to $11 \mathrm{mg}$ $(\mathrm{N})$ or from 0.7 to $0.4 \mathrm{mg}(\mathrm{P})$ from 1000 to $3000 \mathrm{~m}$, in parallel with the reduction in mean leaf size. The less favourable high-elevation environment apparently forces the upper montane trees to allocate the $\mathrm{N}$ and $\mathrm{P}$, which is available for leaf production and photosynthesis, to a smaller total leaf area consisting of small, thick and scleromorphic and long-lived leaves. Third, Moser et al. (2011) found a large increase in the root:shoot ratio of the trees from 1000 to $3000 \mathrm{~m}$ in this transect which was best explained by the large decrease in $\mathrm{N}$ availability (but not $\mathrm{P}$ availability) along the slope.

From our data, a complex picture of the role of $\mathrm{N}$ and $\mathrm{P}$ nutrition for the 82 
photosynthesis and productivity of the Ecuadorian mountain forest trees emerges. While $\mathrm{N}$ shortage is likely one of the causes of the large leaf area reduction along the slope (Moser et al. 2007), the $A_{\max }$ decrease by $30 \%$ from 2000 to $3000 \mathrm{~m}$ is probably a consequence of lowered temperature (and perhaps reduced $\mathrm{P}$ availability) and not caused by $\mathrm{N}$ shortage, because $A_{\max }$ decreased (from 11.3 to $7.2 \mu \mathrm{mol} \mathrm{m} \mathrm{m}^{-2} \mathrm{~s}$ ${ }^{1}$ ) while $\mathrm{N}_{\mathrm{a}}$ increased (from 2.4 to $2.7 \mathrm{~g} \mathrm{~m}^{-2}$; $P_{\mathrm{a}}$ decreased from 128 to $104 \mathrm{mg} \mathrm{m}^{-2}$ ). Since $P_{m}$ was also the principal factor determining leaf dark respiration in our species sample, we assume that the prominent role of foliar $P$ concentration for $A_{\max }$ might relate to the role of energy availability (ATP supply) for leaf metabolism which should increase with decreasing temperatures at higher elevations.

Further studies must show whether our results regarding the likely $P$ effect on tree $A_{\max }$ in tropical high-elevation forests are more generally valid. Elevational $A_{\max }$ patterns may not only differ between mountains with contrasting geology and climate but might also depend on the tree genera and families present in a region which might have different adaptive potentials. From our results, we hypothesize that the photosynthetic capacity should decrease with elevation in mountains with an upslope decrease in $\mathrm{P}$ availability, while montane and sub-alpine forests at sites with a more favourable $\mathrm{P}$ supply should show only small or no elevational reduction in areaspecific $A_{\max }$ rates. This could be tested by comparing elevational transects in tropical mountains on allophane-rich (volcanic) and P-impoverished acidic soils. 


\section{Conclusion}

In support of our third hypothesis, the gas exchange measurements showed a substantial up-regulation of leaf photosynthetic and mitochondrial activity in montane and upper montane trees under the less favourable temperature and $\left[\mathrm{CO}_{2}\right]$ conditions close to the alpine tree line. However, a full compensation was detected only for leaf dark respiration but not for $A_{\max }$. The homeostatic adjustment is mainly caused by changes in leaf morphology, i.e. a large reduction in SLA and the resulting increase in $\mathrm{N}$ and $\mathrm{P}$ content per leaf area. In contrast, we found no indication of a higher carboxylation efficiency at high elevations as was reported, for example, in Hawaiian montane forests. In fact, $\mathrm{V}_{\mathrm{cmax}}$ at ambient temperature was lower at 3000 than at $1000 \mathrm{~m}$ while $J_{\max }$ was higher. This indicates a shift toward increased investment in electron transport capacity with increasing elevation as physiological response to the cloudy and moist environment. The multiple regression analysis identified massrelated foliar $\mathrm{P}$ as the most important environmental factor influencing the variation in $A_{\max }$ between the three elevation levels and among the 40 tree species examined. This highlights the role of $P$ supply for the photosynthetic capacity of tropical trees which was much more important than $\mathrm{N}$. However, from the large decrease in soil $\mathrm{N}$ availability with increasing elevation, the low foliar $\mathrm{N}$ concentration in the uppermost stand, and the marked LAI decrease with elevation, we assumed that $\mathrm{N}$ shortage may reduce the carbon gain of trees at high elevations mainly through limiting the assimilating surface area. Our findings are not only important for achieving a mechanistic understanding of elevational change in tree carbon gain and climate warming response, but they may also contribute to the debate on the causes of alpine tree lines in tropical mountains. 


\section{Acknowledgements}

The authors gratefully acknowledge the financial support by the German Academic Exchange Service (DAAD) and the DFG (FOR 816, subproject A2.2) received for part of the study. Logistic support by the Foundation Nature and Culture International ( $\mathrm{NCl}$, San Diego - Loja) is gratefully acknowledged. We thank the Ministerio del Ambiente de Ecuador for the research permit and Paul Gonzales and Linda Rohnstock for field assistance. We thank two anonymous reviewers for their constructive comments on an earlier version of the manuscript.

\section{References}

Ashton PS (2003) Floristic zonation of tree communities on wet tropical mountains revisited. Perspect Plant Ecol Evol Syst 6:87-104.

Atkin OK, Holly C, Ball MC (2000) Acclimation of snow gum (Eucalyptus pauciflora) leaf respiration to seasonal and diurnal variations in temperature: the importance of changes in the capacity and temperature sensitivity of respiration. Plant Cell Environ 23:15-26.

Ball JT, Woodrow IE, Berry JA (1987) A model predicting stomatal conductance and its contribution to the control of photosynthesis under different environmental conditions. In Biggins J (ed) Progress in Photosynthesis Research IV. Martinus Nijhof Publishers, Dordrecht, the Netherlands. pp. 221-234.

Bendix J, Homeier J, Cueva Ortiz E, Emck P, Breckle S-W, Richter M, Beck E (2006) Seasonality of weather and tree phenology in a tropical evergreen mountain rain forest. International J Biomet 50:370-384.

Bendix J, Rollenbeck R, Richter M, Fabian P, Emck P (2008) Climate. In: Beck E et al. (eds) Gradients in a Tropical Mountain Ecosystem of Ecuador . Springer Verlag, Berlin, Heidelberg. pp. 63-74

Benecke U, Schulze ED, Matyssek R, Havranek WM (1981) Environmental control of $\mathrm{CO}_{2}$-assimilation and leaf conductance in Larix decidua Mill. Oecologia 50:5461.

Benner J, Vitousek PM, Ostertag R (2010) Nutrient cycling and nutrient limitation in tropical montane cloud forests. In Bruijnzeel LA et al. (eds) Tropical Montane Cloud Forests. International Hydrology Series. Cambridge University Press, Cambridge, UK. pp. 90-100. 
Birmann K, Körner C (2009) Nitrogen status of conifer needles at the alpine treeline. Plant Ecol Div 2: 233-241.

Bresson CC, Kowalski AS, Kremer A, Delzon S (2009) Evidence of altitudinal increase in photosynthetic capacity: gas exchange measurements at ambient and constant $\mathrm{CO}_{2}$ partial presssure. Ann For Sci 66: 505.

Breuer L, Exbrayat J-F, Plesca I, Buytaert W, Ehmann T, Peters T, Timbe E, Trachte K, Windhorst D (2013) Global climate change impacts on local climate and hydrology. In: Bendix $\mathrm{K}$ et al. (eds) Ecosystem Services, Biodiversity and Environmental Change in a Tropical Mountain Ecosystem of South Ecuador. Ecological Studies Vol. 221, Springer, Berlin, Heidelberg, New York. pp. 265274.

Bruijnzeel LA, Hamilton LS (2000) Decision Time for Cloud Forests. IHP-UNESCO, Paris.

Bruijnzeel LA, Scatena FN, Hamilton LS (2010) Tropical Montane Cloud Forests. Cambridge University Press, Cambridge, UK.

Cavaleri M, Oberbauer SF, Ryan MG (2008) Foliar and ecosystem respiration in an old-growth tropical rain forest. Plant Cell Environ 31: 473-483.

Cavieres LA, Rada F, Azocar A, Garcia-Nunez C, Cabrera HM (2000) Gas exchange and low temperature resistance in two tropical high mountain tree species from the Venezuelan Andes. Acta Oecol 21:203-211.

Cordell S, Goldstein G, Meinzer FC, Handley LL (1999) Allocation of nitrogen and carbon in leaves of Metrosideros polymorpha regulates carboxylation capacity and $\delta^{13} \mathrm{C}$ along an altitudinal gradient. Funct Ecol 13:811-818.

Cordell S, Goldstein G, Mueller-Dombois D, Webb D, Vitousek PM (1998) Physiological and morphological variation in Metrosideros polymorpha, a dominant Hawaiian tree species, along an altitudinal gradient: the role of phenotypic plasticity. Oecologia 113:188-196.

De Pury DGG, Farquhar GD (1997) Simple scaling of photosynthesis from leaves to canopies without the errors of big-leaf models. Plant Cell Environ 20:537-557.

Emck P (2007) A Climatology of South Ecuador. With Special Focus on the Major Andean Ridge as Atlantic-Pacific Climate Divide. PhD thesis, Universität Erlangen-Nürnberg, Erlangen-Nürnberg, Germany.

Farmer RE (1980) Comparative analysis of first year growth in six deciduous trees. Canadian J For Res 10:35-41.

Fleck S (2002) Integrated Analysis of Relationships Between 3D-Structure, Leaf Photosynthesis, and Branch Transpiration of Mature Fagus Sylvatica and Quercus Petraea Trees in a Mixed Forest Stand. PhD Thesis, University of Bayreuth, Germany. 
Farquhar GD, Caemmerer S, Berry JA (1980) A biochemical model of photosynthetic $\mathrm{CO}_{2}$ assimilation in leaves of C3 species. Planta 149:78-90.

Gentry AH (1988) Tree species richness of upper Amazonian forests. Proceed Nat Acad Sci USA 85:156-159.

Graefe S, Hertel D, Leuschner C (2010) N, P and K limitation of fine root growth along an elevation transect in tropical mountain forests. Acta Oecol 36:537542.

Harley PC, Tenhunen JD (1991) Modeling the photosynthetic response of C3 leaves to environmental factors. In: Boote KJ and Loomis RS (eds) Modeling Crop Photosynthesis - From Biochemistry to Canopy. American Society of Agronomy and Crop Science Society of America, Madison, Wisc., USA. pp. 17-39.

Hastenrath S (1991) Climate Dynamics of the Tropics. Springer, Berlin, Germany.

Hikosaka K, Nagamatsu D, Ishii HS, Hirose T (2002) Photosynthesis-nitrogen relationships in species at different altitudes on Mount Kinabalu, Malaysia. Ecol Res 17:305-313.

Holtmeier F-K, Broll G (1992) The influence of tree islands and microtopography on pedoecological conditions in the forest-alpine tundra ecotone on Niwot Ridge, Colorado Front Range, U.S.A. Arct Alp Res 24:216-228.

Homeier J, Werner FA, Gradstein SR, Breckle S-W, Richter M (2008) Potential vegetation and floristic composition of Andean forests in South Ecuador, with a focus on the RBSF. In: Beck E et al. (eds) Gradients in a Tropical Mountain Ecosystem of Ecuador. Ecological Studies vol. 198, Springer, Heidelberg, Berlin, Germany. pp. 87-100.

Homeier J, Breckle S-W, Günter S, Rollenbeck RT, Leuschner C, (2010) Tree diversity, forest structure and productivity along altitudinal and topographical gradients in a species-rich Ecuadorian montane rain forest. Biotropica 42:140148.

Kitayama K (1995) Biophysical conditions of the montane cloud forest of Mount Kinabalu, Sabah, Malaysia. In: Hamilton LS et al. (eds) Tropical Montane Cloud Forests. Springer, New York, USA. pp. 183-197.

Kitayama K, Aiba SI (2002) Ecosystem structure and productivity of tropical rain forests along altitudinal gradients with contrasting soil phosphorus pools on Mount Kinabalu, Borneo. J Ecol 90:37-51.

Körner C, Farquhar GD, Roksandic Z (1988) A global survey of carbon isotope discrimination in plants from high altitude. Oecologia 74:623-632.

Körner C, Farquhar GD, Wong SC (1991) Carbon isotope discrimination by plants follows latitudinal and altitudinal trends. Oecologia 88:30-40. 
Körner C (2003) Alpine Plant Life: Functional Plant Ecology of High Mountain Ecosystems. Springer, Berlin, Germany.

Lambers H, Chapin III FS, Pons TL 2008. Plant Physiological Ecology. $2^{\text {nd }}$ ed. Springer, New York

Larigauderie A, Körner C (1995) Acclimation of leaf dark respiration to temperature in alpine and lowland plant species. Ann Bot 76:245 -252.

Letts MG, Mulligan M, Rincón-Romero ME, Bruijnzeel LA (2010) Environmental control on photosynthetic rates of lower montane cloud forest vegetation in south-western Colombia. In: Bruijnzeel LA et al. (eds) Tropical Montane Cloud Forests: Science for Conservation and Management. Cambridge University Press, Cambridge, UK. pp. 465-478.

Leuschner C, Moser G, Bertsch C, Röderstein M, Hertel D (2007) Large altitudinal increase in tree root/shoot ratio in tropical mountain forests of Ecuador. Bas Appl Ecol 8:219-230.

Leuschner C, Zach A, Moser G, Homeier J, Graefe S, Hertel D, Wittich B, Soethe N, lost S, Röderstein M, Horna V, Wolf K (2013) The carbon balance of tropical mountain forests along an altitudinal transect, Southern Ecuador. In: Bendix $\mathrm{J}$ et al. (eds) Ecosystem Services, Biodiversity and Environmental Change in a Tropical Mountain Ecosystem of South Ecuador. Ecological Studies Vol. 221, Springer, Berlin, Heidelberg, New York. pp. 117-140.

Losos JB (2008) Phylogenetic niche conservatism, phylogenetic signal and the relationship between phylogenetic relatedness and ecological similarity among species. Ecology Lett 11:995-1003.

Meir P, Levy PE, Grace J, Jarvis PG (2007) Photosynthetic parameters from two contrasting woody vegetation types in West Africa. Plant Ecol 192:277-287.

Milla R, Reich PB (2011) Multi-trait interactions, not phylogeny, fine-tune leaf size reduction with increasing altitude. Ann Bot 107:455.

Morecroft MD, Marrs RH, Woodward FI (1992) Altitudinal and seasonal trends in soil nitrogen mineralization rate in the Scottish highlands. J Ecol 80:49-56.

Moser G, Hertel D, Leuschner C (2007) Altitudinal change in LAI and stand leaf biomass in tropical montane forests: a transect study in Ecuador and a pantropical meta-analysis. Ecosystems 10:924-935.

Moser G, Röderstein M, Soethe N, Hertel D, Leuschner C (2008) Altitudinal changes in stand structure and biomass allocation of tropical mountain forests in relation to microclimate and soil chemistry. In: Beck E et al. (eds) Gradients in a Tropical Mountain Ecosystem of Ecuador. Ecological Studies vol. 198, Springer, Heidelberg, Berlin, Germany. pp. 229-242.

Moser G, Leuschner C, Hertel D, Graefe S, Soethe N, lost S (2011) Elevation effects 
on the carbon budget of tropical mountain forests (S Ecuador): The role of the belowground compartment. Global Change Biol 17:2211-2226.

Norman JM, Welles JM, McDermitt DK (1992) Estimating canopy light-use and transpiration efficiencies from leaf measurements. Li-Cor Application Note\# 105. Li-Cor. Inc., Lincoln, NE, USA.

Pallardy SG (2008) Physiology of Woody Plants. $3^{\text {rd }}$ ed. Academic Press, Amsterdam.

Pendry CA, Proctor J (1996) The causes of altitudinal zonation of rain forests on Bukit Belalong, Brunei. J Ecol 84:407-418.

R Development Core Team (2011) R: A Language and Environment for Statistical Computing. R Foundation for Statistical Computing, Vienna, Austria.

Raich JW, Russell AE, Vitousek PM (1997) Primary productivity and ecosystem development along an elevational gradient on Mauna Loa, Hawai'i. Ecology 78:707-721.

Richardson AD, Berlyn GP, Gregoire TG (2001) Spectral reflectance of Picea rubens (Pinaceae) and Abies balsamea (Pinaceae) needles along an elevational gradient, Mt. Moosilauke, New Hampshire, USA. Am J Bot 88:667-676.

Tanner EVJ, Vitousek PM, Cuevas E (1998) Experimental investigation of nutrient limitation of forest growth on wet tropical mountains. Ecology 79:10-22.

Terashima I, Masuzawa T, Ohba H, Yokoi Y (1995) Is photosynthesis suppressed at higher elevations due to low $\mathrm{CO}_{2}$ pressure? Ecology 76:2663-2668.

Van de Weg MJ, Meir P, Grace J, Atkin OK (2009) Altitudinal variation in leaf mass per unit area, leaf tissue density and foliar nitrogen and phosphorus content along an Amazon-Andes gradient in Peru. Plant Ecol Div 2:243-254.

Van de Weg MJ, Meir P, Grace J, Ramos GD (2012) Photosynthetic parameters, dark respiration and leaf traits in the canopy of a Peruvian tropical montane cloud forest. Oecologia 168:23-34.

Weber MG, Agrawal AA (2012) Phylogeny, ecology, and the coupling of comparative and experimental approaches. Trends Ecol Evol 27:394-403.

Whitmore TC (1989) Tropical forest nutrients, where do we stand? A tour de horizon. In: Proctor $J$ (ed) Mineral Nutrients in Tropical Forest and Savanna Ecosystems. Blackwell Scientific, Oxford, UK. pp. 1-13.

Wieser G, Holtmeier K-F, Smith WK (2013; in press) Treelines in a Changing Global Environment. In Tausz $\mathrm{M}$ and Grulke $\mathrm{N}$ (eds) Trees in a Changing Environment: Ecophysiology, Adaptation and Future Survival. Springer, Heidelberg, Berlin, Germany.

Wittich B, Horna V, Homeier J, Leuschner C (2012) Altitudinal change in the 
photosynthetic capacity of tropical trees: A case study from Ecuador and a pantropical literature analysis. Ecosystems 15:958-973.

Wolf K (2010) Trace Gas Fluxes and Belowground Carbon Allocation in Tropical Montane Forest Soils of Southern Ecuador. PhD thesis, University of Göttingen, Göttingen.

Wolf K, Veldkamp E, Homeier J, Martinson GO (2011) Nitrogen availability links forest productivity, soil nitrous oxide and nitric oxide fluxes of a tropical montane forest in southern Ecuador. Global Biogeoch Cycles 25. GB4009.

Wullschleger SD 1993. Biochemical limitations to carbon assimilation in C3 plants-a retrospective analysis of the $\mathrm{A} / \mathrm{Ci}$ curves from 109 species. J Exp Bot 44:907 920.

Zanne AE, Lopez-Gonzales G, Coomes DA, Illic J, Jansen S, Lewis SL, Miller RB, Swenson NG, Wiemann MC, Chave J (2009) Data from: Towards a worldwide wood economics spectrum. Dryad Digital Repository. doi:10.5061/dryad.234. 


\section{CHAPTER 4}

\section{Ammonium, nitrate and glycine uptake of six Ecuadorian tropical montane forest tree species: an in situ pot experiment with saplings}

Bärbel Wittich, Jürgen Homeier and Christoph Leuschner

Submitted to: Journal of Tropical Ecology 


\section{Abstract}

Not much is known about the nitrogen $(\mathrm{N})$ uptake capacity and $\mathrm{N}$-form preference of tropical trees. In a replicated labelling experiment with ${ }^{15} \mathrm{~N}$-ammonium, ${ }^{15} \mathrm{~N}$-nitrate and dual-labelled glycine applied to saplings of six tree species from southern Ecuadorian montane forests, we tested the hypotheses that (1) the saplings of tropical trees are capable of using organic $\mathrm{N}$ even though they are forming arbuscular mycorrhizas, and (2), with increasing elevation, tree saplings increasingly prefer ammonium and glycine over nitrate due to reduced nitrification and growing humus accumulation. Three- to 5-yr-old saplings of two species each from 1000, 2000 and $3000 \mathrm{~m}$ elevation were grown in pots inside the forest at their origin and labelled with non-fertilizing amounts of the three $\mathrm{N}$ forms; ${ }^{15} \mathrm{~N}$ enrichment was detected $5 \mathrm{~d}$ after labelling in fine roots, coarse roots, shoots and leaves. The six species differed with respect to their $\mathrm{N}$-form preference, but neither the abundance of ammonium and nitrate in the soil nor elevation (1000-3000 m asl) seemed to influence the preference. Two species (those with highest growth rate) preferred $\mathrm{NH}_{4}{ }^{+}$over $\mathrm{NO}_{3}{ }^{-}$, while the other four species took up $\mathrm{NO}_{3}{ }^{-}$and $\mathrm{NH}_{4}{ }^{+}$at similar rates when both $\mathrm{N}$ forms were equally available. After ${ }^{13} \mathrm{C}$-glycine addition, ${ }^{13} \mathrm{C}$ was significantly accumulated in the biomass of three species (two species with exclusively AM and one species with ECM and AM symbionts) giving a first hint toward organic $N$ use by tropical montane forest trees irrespective of the type of their mycorrhiza.

Key words: dual-labelled glycine, elevational gradient, Graffenrieda harlingii, Hedyosmum translucidum, Hedyosmum purpurascens, Hedyosmum sprucei, Myrcia sp. nov., nitrogen uptake, Pouteria torta, ${ }^{15} \mathrm{~N}$ tracer study 


\section{Introduction}

Nitrogen $(N)$ and phosphorus $(P)$ are thought to be the principal growth-limiting nutrient elements in tropical rainforests (Tanner et al. 1998) but their relative importance is not entirely clear and seems to vary with site conditions. While $P$ likely is limiting the productivity of many tropical lowland forests, $\mathrm{N}$ shortage may be more decisive in tropical montane forests on younger soils and under lowered temperatures (Paoli et al. 2005, Tanner 1981, Vitousek \& Sanford 1986). Studies along elevation gradients in tropical mountains found marked decreases in ammonification rate with elevation and even steeper decreases in nitrification rate, because the activity of autotrophic nitrifiers is particularly sensitive to the cool and often acidic soil conditions at higher elevations (Jones et al. 2009, Marrs et al. 1988, Wolf et al. 2011). Thus, not only the relative importance of $N$ and $P$ shortage may vary with elevation, but the supply rates of $\mathrm{NH}_{4}{ }^{+}$and $\mathrm{NO}_{3}{ }^{-}$and the relative availability of the two $\mathrm{N}$ forms as well. Moreover, the depth of organic layers on top of the soil was found to greatly increase with elevation in tropical mountains (Moser et al. 2011, Wolf et al. 2011 ) suggesting that organic $\mathrm{N}$ forms should be more readily available for plant use at high elevations. As a consequence, $\mathrm{N}$ supply should vary greatly across elevation and exposition gradients in tropical mountain forests. Given that many tropical mountain forests are rich in tree species, one might assume that the heterogeneity in $\mathrm{N}$ supply patterns is associated with plurality in $\mathrm{N}$ acquisition strategies in the trees. Studies in temperate and boreal forests suggest that trees with apparent preference of ammonium are more abundant in cold environments and that the importance of organic $\mathrm{N}$ forms for tree nutrition increases with decreasing decomposition and $\mathrm{N}$ mineralization rate (Finzi \& Berthrong 2005, Kielland 1994, 1997, Näsholm et al. 1998). If these patterns are also valid in tropical mountains, we predict a higher abundance of nitrate-preferring trees at lower elevation and a dominance of trees with preference of organic $\mathrm{N}$ and/or ammonium at higher elevation. However, in contrast to temperate and boreal forests, the large majority of tropical tree species seem to form arbuscular mycorrhizas (AM) (Kottke et al. 2004) 
and not ectomycorrhizal associations (ECM).

So far, information on the preference of different $\mathrm{N}$ forms by tropical trees is lacking. $\mathrm{N}$ acquisition strategies in tropical forest plants have been studied for hemi-epiphytic Clusiaceae (Arndt et al. 2002, Wanek et al. 2002), understorey palms (Andersen \& Turner 2013), and rain-forest bryophytes (Wanek \& Pörtl 2008), but not for trees. The first study showed that hemi-epiphyte Clusia minor can use ammonium, nitrate and also glycine under greenhouse conditions, but three other Clusia species seem to prefer $\mathrm{NH}_{4}{ }^{+}$or glycine over $\mathrm{NO}_{3}{ }^{-}$under field conditions (Wanek et al. 2002). Andersen \& Turner (2013) found seedlings of understorey palms to be able to use organic nitrogen with no preferences for chemical forms of $\mathrm{N}$ but an overall acquisition pattern of glycine $\geq \mathrm{NO}_{3}{ }^{-} \geq \mathrm{NH}_{4}{ }^{+}$. It is not known whether $\mathrm{N}$ form preferences differ among co-occurring dicotyledonous tree species in species-rich tropical forests and whether preferences change with alteration in inorganic and organic $\mathrm{N}$ availability along mountain slopes.

In this study, we examined the uptake of ammonium, nitrate and glycine by seedlings of six native tree species from three Ecuadorian montane forests that were grown under natural conditions in pots inside the forest at 1000, 2000 and $3000 \mathrm{~m}$ asl (two species per elevation). $\mathrm{NH}_{4}{ }^{+}, \mathrm{NO}_{3}{ }^{-}$and glycine were added at low doses $\left(5 \mathrm{~kg} \mathrm{~N} \mathrm{ha}^{-1}\right)$ with ${ }^{15} \mathrm{~N}$-labelled solutions (or dual-labelled glycine solution) and the plants were harvested after $5 \mathrm{~d}$. For measuring $\mathrm{N}$ uptake under conditions as close to nature as possible, we used intact plants instead of excised roots and grew the plants under the characteristic low-light conditions on the forest floor where they received natural rainfall. The main objectives of the study were (1) to search for a significant elevation effect on the $\mathrm{N}$ form preference in tropical tree species, and (2) to examine the role of organic nitrogen (glycine) for the nutrition of trees in tropical mountain forests. More specifically, we tested the hypotheses that (1) the saplings of tropical trees are capable of using organic $\mathrm{N}$ even though they form arbuscular mycorrhiza, and (2), with increasing altitude, tree saplings increasingly prefer ammonium and glycine over nitrate due to a lowered nitrification rate and increased humus accumulation. 


\section{Methods}

\section{Study sites}

This study took place in tropical montane forests on the eastern slope of the South Ecuadorian Andes along a 2000-m elevation transect. Three study sites were selected at ca. 1000, 2000 and 3000 m asl in Podocarpus National Park and in the Reserva San Francisco in the Provinces of Loja and Zamora-Chinchipe (Figure 1). The study area has a tropical humid climate with a very wet season in April-July and experiences a less humid period from September to December (Bendix et al. 2006). Regularly occurring longer dry periods do not exist. Table 1 gives further details on the climatic conditions at the study sites.

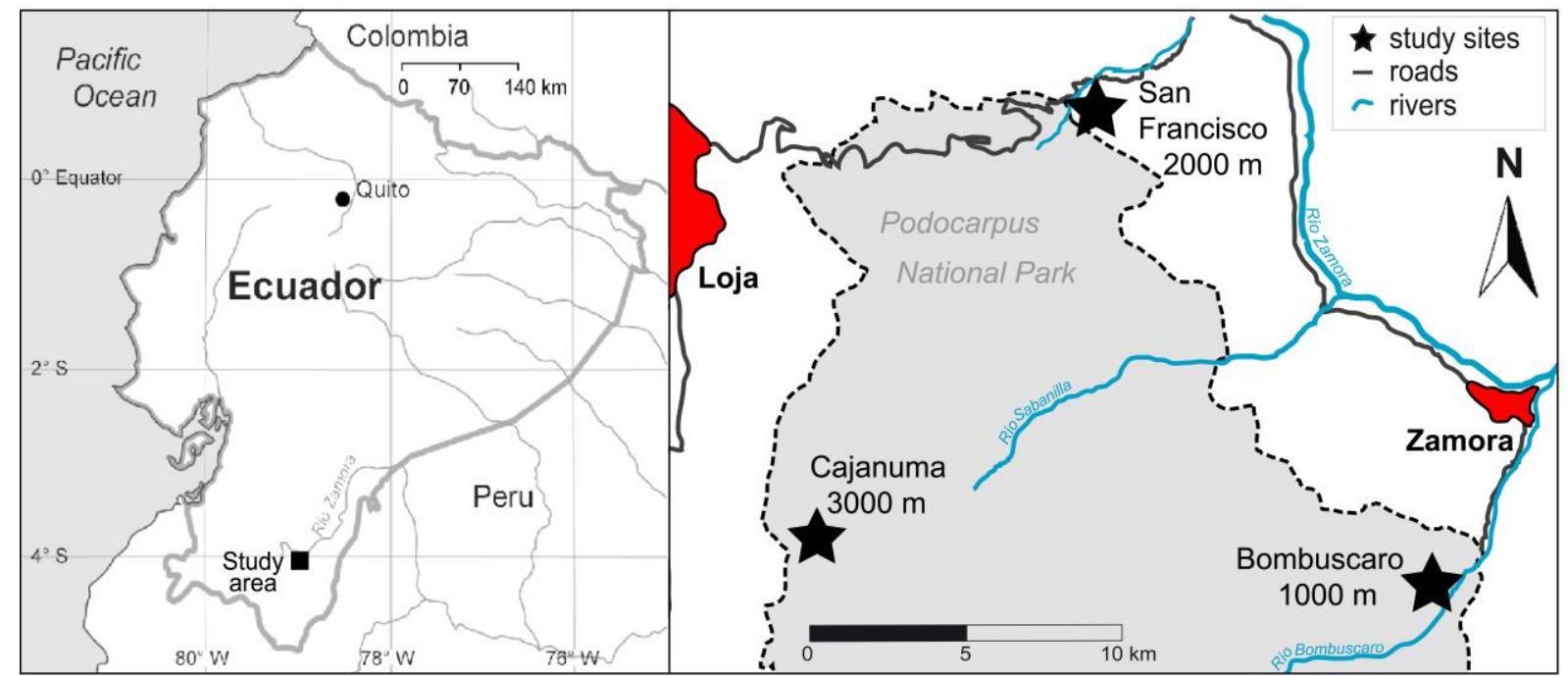

Figure 1. Location of the study area in southern Ecuador with the three stands at 1000, 2000 and $3000 \mathrm{~m}$ asl. 
According to Homeier et al. (2008), the forests at the study sites can be classified as follows: At $1000 \mathrm{~m}\left(4^{\circ} 7^{\prime} \mathrm{S}, 78^{\circ} 58^{\prime} \mathrm{W}\right)$, in the transition zone between tropical lowland and lower montane forest, evergreen forest with tree heights of up to $40 \mathrm{~m}$ is present. Common tree families of this forest type are Fabaceae, Melastomataceae, Moraceae, Myristicaceae, Rubiaceae and Sapotaceae. The evergreen lower montane forest at $2000 \mathrm{~m}\left(3^{\circ} 58^{\prime} \mathrm{S}, 7^{\circ} 04^{\prime} \mathrm{W}\right)$ achieves a canopy height of 18-22 $\mathrm{m}$. Characteristic tree families are Euphorbiaceae, Lauraceae, Melastomataceae and Rubiaceae. At 3000 $\mathrm{m}\left(4^{\circ} 7^{\prime} \mathrm{S}, 79^{\circ} 11^{\prime} \mathrm{W}\right)$, evergreen upper montane forests and elfin-forests are found that extend up to the tree line; canopy height rarely exceeds 8-10 m. Dominant tree families are Aquifoliaceae, Clusiaceae, Cunoniaceae, Lauraceae and Melastomataceae.

All soils are acidic with a progressive $\mathrm{pH}$ decrease toward higher elevation. With increasing elevation, soil nutrient availability also decreases along the elevation transect. Both $\mathrm{N}$ net mineralization and nitrification rate decreased with elevation, as does the mineral $\mathrm{N}$ concentration of the topsoil (Table 1, after Wolf et al. 2011). The $\delta^{15} \mathrm{~N}$ signature of the mineral topsoil material and the organic layer decreases in general from 1000 to $3000 \mathrm{~m}$ by about 1.5\%o (difference significant between 2000 and $3000 \mathrm{~m}$ ). The mean $\delta^{15} \mathrm{~N}$ value of tree sun leaves increased from $+1.1 \%$ at 1000 $\mathrm{m}$ to c. $+2.4 \%$ at $2000 \mathrm{~m}$ and rapidly dropped to $-1.5 \%$ at $3000 \mathrm{~m}$; foliar $\mathrm{N}$ concentration followed this pattern with a mid-slope peak at $2000 \mathrm{~m}$ (Wittich et al. 2012) (Figure 2). Kottke et al. (2004) investigated the mycorrhizal status of the tree species in the montane forests of southern Ecuador and found more than $95 \%$ of the species to be colonised by AM fungi without the formation of ECM. In our stand at $2000 \mathrm{~m}$, five of ca. 300 abundant tree species including the genus Graffenrieda were found to form ECM (I. Haug, pers. comm.). 
Table 1. Characteristics of the studied forest stands in the elevation transect in southern Ecuador (climate data from Moser et al. (2007); soil data from Wolf et al. (2011) and A. Baldos, unpubl. data). $\mathrm{C} / \mathrm{N}$ ratio, $\mathrm{pH}$, net nitrification and net $\mathrm{N}$ mineralization rate (in situ buried bag method) refer to the topsoil $(0-10 \mathrm{~cm})$, organic $\mathrm{N}$ concentrations to $0-5 \mathrm{~cm}$.

\begin{tabular}{|c|c|c|c|}
\hline Elevation ( $\mathrm{m}$ asl) & 1000 & 2000 & 3000 \\
\hline Rainfall $\left(\mathrm{mm} \mathrm{y}^{-1}\right)$ & c. 2230 & c. 1950 & c. 4500 \\
\hline Air temperature $\left({ }^{\circ} \mathrm{C}\right)$ & 19 & 16 & 9 \\
\hline Air humidity (\%) & 86 & 91 & 94 \\
\hline $\mathrm{pH}\left(\mathrm{H}_{2} \mathrm{O}\right)$ & $4.9 \pm 0.2$ & $4.4 \pm 0.2$ & $3.9 \pm 0.1$ \\
\hline $\mathrm{C} / \mathrm{N}$ & $17.6 \pm 0.8$ & $14.8 \pm 0.7$ & $18.2 \pm 0.9$ \\
\hline Net $\mathrm{N}$ mineralization $\left(\mathrm{kg} \mathrm{N}^{-1}\right.$ per $10 \mathrm{~d}$ ) & $2.5 \pm 0.6$ & $1.5 \pm 0.3$ & $0.1 \pm 0.2$ \\
\hline Net Nitrification (kg N ha ${ }^{-1}$ per $\left.10 \mathrm{~d}\right)$ & $1.97 \pm 0.73$ & $0.89 \pm 0.30$ & $0.01 \pm 0.01$ \\
\hline $\mathrm{KCl}$-extractable $\mathrm{NO}_{3}^{-}\left(\mathrm{kg} \mathrm{N} \mathrm{ha}^{-1}\right)$ & $0.43 \pm 0.10$ & $0.24 \pm 0.05$ & $0.02 \pm 0.01$ \\
\hline $\mathrm{KCl}$-extractable $\mathrm{NH}_{4}^{+}\left(\mathrm{kg} \mathrm{N} \mathrm{ha}^{-1}\right)$ & $1.8 \pm 0.3$ & $0.9 \pm 0.1$ & $0.7 \pm 0.1$ \\
\hline $\mathrm{K}_{2} \mathrm{SO}_{4}$-extractable organic $\mathrm{N}\left(\mathrm{mg} \mathrm{kg}^{-1}\right)$ & $36.3 \pm 2.3$ & $138.6 \pm 10.6$ & $127.6 \pm 4.4$ \\
\hline
\end{tabular}

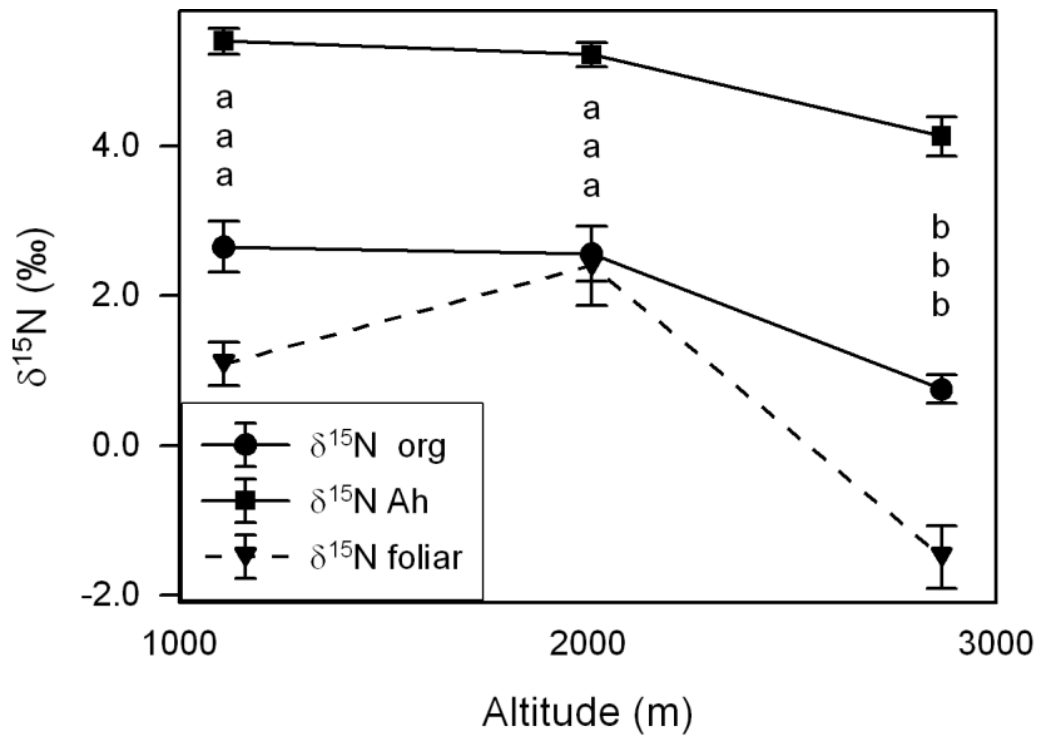

Figure 2. $\delta^{15} \mathrm{~N}$ signatures (mean $\pm S E ; 18$ plots per elevation) in canopy leaves (mean of various tree species per elevation) and in the soil (organic layer and 0-30 cm of mineral soil) at 1000, 2000 and $3000 \mathrm{~m}$ asl in the study transect after data from Wolf et al. (2011) and unpublished data of K. Wolf. 


\section{Plant material}

The forests in the study area are extremely diverse with $\geq 800$ tree species present (J. Homeier, unpubl. data) and no tree species was found to be abundant at all three study sites (1000, 2000 and $3000 \mathrm{~m}$ ). We selected six tree species (two each per site) that were considered to be representative for the sites because they occurred more frequently in the stands than elsewhere: Pouteria torta (Mart.) Radlk. (Sapotaceae) and Hedyosmum sprucei Solms (Chloranthaceae) at $1000 \mathrm{~m}$ asl, Myrcia sp. nov (undescribed species, Myrtaceae) and Hedyosmum translucidum Cuatrec. (Chloranthaceae) at $2000 \mathrm{~m}$, and Graffenrieda harlingii Wurdack (Melastomataceae) and Hedyosmum purpurascens Todzia (Chloranthaceae) at 3000 $\mathrm{m}$. Hedyosmum is one of the very few genera found from 1000 to $3000 \mathrm{~m}$ asl in the study area. Characteristics of the six species are summarized in Table 2.

Some 4-6 mo before the start of the experiment, saplings of all species were collected from the three stands and planted into plastic pots. According to sapling monitoring studies in the field (Homeier et al., umpubl.), the plants were approximately 3-5 y in age at the time of the experiment. Average shoot height was $27 \mathrm{~cm}$. The pots of $25 \mathrm{~cm}$ diameter and $25 \mathrm{~cm}$ height were filled with local forest soil from the sites where the saplings had been collected. We used mineral topsoil (upper $25 \mathrm{~cm}$ ) from patches of undisturbed primary forest. The pots with each one sapling growing in it were placed on wooden tables at the three study sites in the interior of the local stands under closed forest canopy. Photosynthetically active radiation at the height of the pots was on average $4.5 \%$ of incident flux density (range $=2.04-7.14 \%$; measured with a LI-1000 Quantum Sensor, Licor Biosciences, Lincoln, NE, USA). By placing two layers of fine-meshed polypropylene net on the soil surface of the pots, we prevented water logging after strong rainfall events. 
Table 2. Characteristic parameters of the tree species investigated in this study. Given are ranges for mature trees growing in the study region (unpublished data) and means $( \pm \mathrm{SE})$ for the seedlings studied for the tracer study. AM: arbuscular mycorrhiza; ECM: ectomycorrhiza (after I. Haug, pers. commun.). Number of replicates per treatment and per date (*three harvest dates for $P$. torta and $H$. purpurascens). The number of replicate measurements in brackets.

\begin{tabular}{|c|c|c|c|c|c|c|}
\hline \multirow{2}{*}{$\begin{array}{l}\text { Elevation } \\
\text { Species }\end{array}$} & \multicolumn{2}{|c|}{$1000 \mathrm{~m}$ asl } & \multicolumn{2}{|c|}{$2000 \mathrm{~m}$ asl } & \multicolumn{2}{|c|}{$3000 \mathrm{~m}$ asl } \\
\hline & Pouteria torta & $\begin{array}{l}\text { Hedyosmum } \\
\text { sprucei }\end{array}$ & Myrcia sp. nov & $\begin{array}{l}\text { Hedyosmum } \\
\text { translucidum }\end{array}$ & $\begin{array}{c}\text { Graffenrieda } \\
\text { harlingii }\end{array}$ & $\begin{array}{l}\text { Hedyosmum cf. } \\
\text { purpurascens }\end{array}$ \\
\hline Mycorrhizal status & AM & AM & AM & AM & ECM / AM & AM \\
\hline Successional status & $\begin{array}{l}\text { Late } \\
\text { successional }\end{array}$ & $\begin{array}{c}\text { Early } \\
\text { successional }\end{array}$ & $\begin{array}{l}\text { Late } \\
\text { successional }\end{array}$ & $\begin{array}{c}\text { Early } \\
\text { successional }\end{array}$ & $\begin{array}{c}\text { Early } \\
\text { successional }\end{array}$ & $\begin{array}{c}\text { Early } \\
\text { successional }\end{array}$ \\
\hline Mature trees & & & & & & \\
\hline Leaf $\mathrm{N}$ concentration $\left(\mathrm{mg} \mathrm{g}^{-1}\right)$ & $14.1-17.8(11)$ & $18.4(1)$ & $8.5-11.4(6)$ & & $13.4-15.3(5)$ & $13.9-16.9(8)$ \\
\hline $\operatorname{SLA}\left(\mathrm{cm}^{2} \mathrm{~g}^{-1}\right)$ & 66.6-99.8 (8) & $126.5(1)$ & 32.4-36.8 (6) & & 49.4-62.5 (5) & $64.5-87.2(8)$ \\
\hline Saplings & & & & & & \\
\hline $\begin{array}{l}\text { Shoot height }(\mathrm{cm}) \\
\text { Leaf } N \text { concentration }\left(\mathrm{mg} \mathrm{g}^{-1}\right)\end{array}$ & $\begin{array}{l}27 \pm 1 \\
20 \pm 1\end{array}$ & $\begin{array}{l}23 \pm 1 \\
17 \pm 1\end{array}$ & $\begin{array}{l}12 \pm 1 \\
15 \pm 0\end{array}$ & $\begin{array}{l}58 \pm 3 \\
22 \pm 1\end{array}$ & $\begin{array}{l}22 \pm 1 \\
17 \pm 2\end{array}$ & $\begin{array}{l}22 \pm 1 \\
20 \pm 1\end{array}$ \\
\hline Number of replicates per treatment & $3^{*}$ & 5 & 4 & 4 & 5 & $4^{*}$ \\
\hline
\end{tabular}


${ }^{15} \mathrm{~N}$ and ${ }^{13} \mathrm{C}$ tracer application

For determining the optimal time of harvest in the ${ }^{15} \mathrm{~N}$ labelling experiment, we conducted a preliminary study with Pouteria torta saplings at $1000 \mathrm{~m}$ and with Hedyosmum purpurascens saplings at $3000 \mathrm{~m}$. We harvested the leaves of selected plants at seven different time steps $\left(2 \mathrm{~h}-18\right.$ d) after adding ${ }^{15} \mathrm{~N}$-ammonium, ${ }^{15} \mathrm{~N}$ nitrate or ${ }^{15} \mathrm{~N}$-glycine solution and calculated the temporal development of ${ }^{15} \mathrm{~N}$ accumulation into leaf biomass. This preliminary experiment with all three $\mathrm{N}$ forms indicated a measurable increase in the first $6 \mathrm{~d}$ and a very slow further increase (or even a decrease) in the ${ }^{15} \mathrm{~N}$ values in the leaves when more than $6 \mathrm{~d}$ (up to $18 \mathrm{~d}$ ) had passed after application. The harvest times were chosen according to these results and they are also based on the time lag of response found by Graefe et al. (2011) who conducted an experiment on the stimulation of tree fine-root growth by locally adding $\mathrm{N}, \mathrm{P}$ or $\mathrm{K}$ at the study sites.

For every tree species, four treatments with three- to fivefold replication (Table 2, depending on plant availability) were established: (1) control (only water added), (2) addition of labelled nitrate $\left(\mathrm{NH}_{4}{ }^{15} \mathrm{NO}_{3}, 98\right.$ atom-\%), (3) addition of labelled ammonium $\left({ }^{15} \mathrm{NH}_{4} \mathrm{NO}_{3} ; 98\right.$ atom-\%), and (4) addition of ${ }^{15} \mathrm{~N}{ }^{13} \mathrm{C}$ dual-labelled glycine $\left(\mathrm{H}_{2}{ }^{15} \mathrm{~N}^{13} \mathrm{CH}_{2}{ }^{13} \mathrm{CO}_{2} \mathrm{H} ; 98\right.$ atom-\%). Thus, the experiment consisted of c. 32 pots each (2 species $\times 4$ treatments $\times 4(3-5)$ replicates) at the three elevations. Since exclusive uptake of ammonium or nitrate leads to acidification or alkalinisation of the rhizosphere, we applied ammonium-nitrate with specific labelling of only one of the components $\left(\mathrm{NH}_{4}{ }^{+}\right.$or $\left.\mathrm{NO}_{3}{ }^{-}\right)$in order to exclude soil pH effects on uptake kinetics. The ${ }^{15} \mathrm{~N}$ tracer was added on 13 April 2010 to all pots (except for the control) at $1000 \mathrm{~m}$ asl and on 14 April 2010 to the pots at 2000 and $3000 \mathrm{~m}$ asl as $50 \mathrm{ml}$ solution in a dose of $5 \mathrm{~kg} \mathrm{~N} \mathrm{ha}^{-1}(0.3 \mathrm{~g} \mathrm{~N}$ per pot) calculated on the basis of the pot surface area.

In order to avoid losses of the added ${ }^{15} \mathrm{~N}$ ammonium through nitrification, we added the nitrification inhibitor dicyandiamide (DCD, AlzChem Trostberg GmbH, Trostberg, Germany) to all ${ }^{15} \mathrm{~N}$-ammonium pots (20 mg 14 atom\%-DCD-N); DCD is widely used in agriculture and decomposes in soil into non-toxic components (Di \& Cameron 100 
2004, Zacherl \& Amberger 1990). The concentration used was shown to inhibit nitrification for 6-10 d in tropical soils (Verma et al. 2007).

\section{Harvest and analysis}

All investigated plants were harvested either $5 \mathrm{~d}$ after nutrient application $(H$. sprucei (1000 m), Myrcia, H. translucidum (2000 m), Graffenrieda (3000 m)), or 2, 5 and $8 \mathrm{~d}$ after application (Pouteria $(1000 \mathrm{~m})$, H. purpurascens $(3000 \mathrm{~m})$ ) to document the temporal course of ${ }^{15} \mathrm{~N}$ acquisition in plant biomass. In the latter two species, a three times larger number of experimental plants was cultivated.

Plants were cut into leaves, shoot and roots. The roots were washed immediately to remove all soil. The plant material was dried at $70^{\circ} \mathrm{C}$ for $48 \mathrm{~h}$ and transferred to Germany. Roots were separated into coarse roots and fine roots (diameter of dried fine roots $<1.5 \mathrm{~mm}$ ) and all plant material was weighed.

The ${ }^{15} \mathrm{~N}$ and ${ }^{13} \mathrm{C}$ concentrations and the total concentrations of $\mathrm{N}$ and $\mathrm{C}$ in the plant biomass were determined with an elemental analyser (NA 1108, Fisons-Instruments, Rodano, Milano, Italy) coupled with an isotope mass ratio spectrometer (Delta plus, Finnigan MAT, Bremen, Germany) in the Laboratory for Stable Isotope Research at Göttingen University (KOSI). The ${ }^{15} \mathrm{~N}$ concentration in the dry mass of the organs of all treatments including the control was calculated as atom\% ${ }^{15} \mathrm{~N}$ of total $\mathrm{N}$. Percental recovery of ${ }^{15} \mathrm{~N}$ in a given organ is the total amount of ${ }^{15} \mathrm{~N}$ (minus the background level, i.e. untreated control plants) detected in the organ's biomass related to the ${ }^{15} \mathrm{~N}$ amount added to the pot at the experiment's start.

In the case of dual-labelled glycine, we calculated the ${ }^{15} \mathrm{~N}$ concentration of the sample after ${ }^{15} \mathrm{~N}^{13} \mathrm{C}$-glycine addition with two different approaches. The first enrichment value was derived directly from the ${ }^{15} \mathrm{~N}$ values measured with the mass ratio spectrometer (termed glycine $-{ }^{15} \mathrm{~N}$ approach hereafter). This calculation should include all ${ }^{15} \mathrm{~N}$ that is accumulated in that plant organ (the balance of influx into minus efflux out of the organ) from the labelled glycine either through uptake of intact 
glycine or glycine deaminated prior to plant uptake. The second approach (glycine${ }^{13} \mathrm{C}$ ) corrects this figure by considering the accumulation of ${ }^{13} \mathrm{C}$ based on the following equation:

${ }^{15} N\left(\right.$ glycine $\left.-{ }^{13} C\right)=\frac{0.5\left(A_{C G}-A_{C C}\right) T_{C G} B_{G} M(N)}{T_{N G} B_{G} M(C)}+A_{N C}$

with $A_{C G}$ being the ${ }^{13} \mathrm{C}$ concentration of the glycine-treated plants (in atom-\%), $A_{C C}$ the mean ${ }^{13} \mathrm{C}$ concentration of the control plants (in atom-\%), $\mathrm{T}_{\mathrm{CG}}$ the total $\mathrm{C}$ concentration of the glycine-treated plants (in $\mathrm{g} \mathrm{g}^{-1}$ ), $\mathrm{B}_{\mathrm{G}}$ the biomass of the glycinetreated plants (in $\mathrm{g}$ ), $\mathrm{T}_{\mathrm{NG}}$ the total $\mathrm{N}$ concentration of the glycine-treated plants (in $\mathrm{g} \mathrm{g}^{-}$ ${ }^{1}$ ), $\mathrm{M}(\mathrm{N})$ the molar mass of ${ }^{15} \mathrm{~N}$ (in $\mathrm{g} \mathrm{mol}^{-1}$ ), $\mathrm{M}(\mathrm{C})$ the molar mass of ${ }^{13} \mathrm{C}$ (in $\mathrm{g} \mathrm{mol}^{-1}$ ), and $A_{N C}$ the ${ }^{15} \mathrm{~N}$ concentration of the control (in atom-\%).

This calculation assumes that ${ }^{13} \mathrm{C}$ enrichment is a reliable indicator of the synchronous uptake of the $\mathrm{C}$ skeleton and the amino group of the glycine molecule. The glycine $-{ }^{15} \mathrm{~N}$ approach may overestimate the amount of glycine taken up by the plant due to deamination in the soil prior to plant uptake, while the glycine $-{ }^{13} \mathrm{C}$ approach may underestimate the amount due to ${ }^{13} \mathrm{C}$ loss in the form of ${ }^{13} \mathrm{CO}_{2}$ respired after plant uptake (Näsholm \& Persson 2001). By plotting the ${ }^{13} \mathrm{C}_{\text {excess }}$ values against the corresponding ${ }^{15} \mathrm{~N}_{\text {excess }}$ values, we tested for glycine uptake in intact form which would show a 2:1 line.

Data analysis

Data analysis focused on treatment differences within a species, i.e. acquisition of $\mathrm{NH}_{4}^{+}, \mathrm{NO}_{3}{ }^{-}$or glycine relative to the untreated control which served for obtaining the ${ }^{15} \mathrm{~N}$ background levels. We refrained from analysing for species differences because the six species differed largely in growth rate. Analysis of variance (Scheffés test) was used to conduct multiple comparisons among the means of the three stands. If the data were not normally distributed according to a Shapiro-Wilk test, the MannWhitney two-sample test (Wilcoxon $U$ test) was used instead of Scheffé's test. All 102 
calculations were conducted with SAS software (version 9.1; SAS Institute, Cary, NC, USA). A significance level of $5 \%$ was used throughout the analysis.

\section{Results}

\section{Uptake of different $N$ forms}

Five $d$ after tracer application, we found a characteristic pattern of tracer enrichment in the plants with generally highest ${ }^{15} \mathrm{~N}$ concentrations in fine roots and a decrease in the sequence coarse roots - shoot - leaves in all six species and all three $\mathrm{N}$ forms (Table 3). High atom-\% ${ }^{15} \mathrm{~N}$ values were found in the fine roots of $\mathrm{H}$. sprucei $(7.53$ atom-\%) while leaves typically did not exceed 1 atom-\% (except in $\mathrm{H}$. sprucei and $\mathrm{G}$. harlingii). In the two treatments with inorganic $\mathrm{N}$ addition (ammonium-nitrate), in general more ${ }^{15} \mathrm{~N}$ label was accumulated when $\mathrm{NH}_{4}{ }^{+}$was labelled as compared to $\mathrm{NO}_{3}{ }^{-}$labelling which indicates higher ammonium uptake when both $\mathrm{N}$ forms were equally available (Table 3). However, the difference between the two treatments was only significant in certain species and biomass fractions $(H$. sprucei: leaves; $H$. translucidum; fine roots, coarse roots and shoot).

Figure 3 gives the temporal development of ${ }^{15} \mathrm{~N}$ accumulation in two species, $\mathrm{P}$. torta at $1000 \mathrm{~m}$ asl and $\mathrm{H}$. purpurascens at $3000 \mathrm{~m}, 2,5$ and $8 \mathrm{~d}$ after application. In $\mathrm{H}$. purpurascens at the high-elevation site $(3000 \mathrm{~m}),{ }^{15} \mathrm{~N}$ recovery increased from day 0 to day 2 and further to day 5 (slight increase in fine roots, marked increase in total biomass) in all treatments, and decreased from day 5 onwards (except for the ammonium treatment which showed further increase). In P. torta, the accumulation patterns were in general similar but ${ }^{15} \mathrm{~N}$ recovery in the biomass was much lower in this species. In contrast to $\mathrm{H}$. purpurascens, the ${ }^{15} \mathrm{~N}$ content in the glycine treatment of the P. torta saplings increased strongly between day 5 and day 8 when calculated as glycine- ${ }^{15} \mathrm{~N}$. 
Table $3 .{ }^{15} \mathrm{~N}$ concentration (in atom-\%) in the saplings of six tree species grown in pots outdoor inside three tropical montane forests in southern Ecuador at 1000, 2000 and $3000 \mathrm{~m}$ asl that were harvested $5 \mathrm{~d}$ after the application of labelled nitrate, ammonium or glycine (means $\pm \mathrm{SE}, \mathrm{N}=3-5$ ). The ${ }^{15} \mathrm{~N}$ enrichment in the glycine treatment is presented either as uncorrected value (glycine $-{ }^{15} \mathrm{~N}$ ) or corrected to the amount of ${ }^{13} \mathrm{C}$ accumulated which may indicate uptake of intact glycine molecules $\left(\mathrm{glycine}-{ }^{13} \mathrm{C}\right)$. Some saplings (such as all Myrcia saplings) had no coarse roots; consequently, some values and statistics are missing. Different letters indicate significant differences between treatments.

\begin{tabular}{|c|c|c|c|c|c|c|c|c|c|c|c|}
\hline \multirow[t]{2}{*}{ Species } & \multirow[t]{2}{*}{ Organ } & \multicolumn{10}{|c|}{${ }^{15} \mathrm{~N}$ concentration ( atom-\%) } \\
\hline & & Control & & Nitrate & & Ammonium & & Glycine $\left({ }^{15} \mathrm{~N}\right)$ & & Glycine $\left({ }^{13} \mathrm{C}\right)$ & \\
\hline \multicolumn{12}{|l|}{$1000 \mathrm{~m}$ asl } \\
\hline \multirow[t]{4}{*}{ Pouteria torta } & Fine roots & $0.44 \pm 0.03$ & a & $1.00 \pm 0.26$ & $\mathrm{a}$ & $1.10 \pm 0.36$ & a & $0.93 \pm 0.15$ & $\mathrm{a}$ & $0.46 \pm 0.01$ & a \\
\hline & Coarse roots & $0.44 \pm 0.01$ & $\mathrm{a}$ & $0.54 \pm 0.02$ & $b$ & $0.67 \pm 0.02$ & & $0.48 \pm 0.01$ & & $0.49 \pm 0.02$ & a \\
\hline & Shoot & $0.42 \pm 0.02$ & a & $0.43 \pm 0.02$ & a & $0.52 \pm 0.08$ & a & $0.42 \pm 0.01$ & $\mathrm{a}$ & $0.45 \pm 0.00$ & a \\
\hline & Leaves & $0.38 \pm 0.00$ & a & $0.39 \pm 0.00$ & & $0.39 \pm 0.01$ & a & $0.39 \pm 0.00$ & $\mathrm{a}$ & $0.39 \pm 0.00$ & a \\
\hline \multicolumn{12}{|l|}{ Hedyosmum } \\
\hline \multirow[t]{4}{*}{ sprucei } & Fine roots & $0.48 \pm 0.03$ & $a$ & $3.93 \pm 1.30$ & $a b$ & $6.28 \pm 0.77$ & b & $7.53 \pm 1.27$ & $\mathrm{~b}$ & $0.55 \pm 0.04$ & $\mathrm{a}$ \\
\hline & Coarse roots & $0.59 \pm 0.08$ & a & $1.72 \pm 0.18$ & $a b$ & $3.82 \pm 0.42$ & $b c$ & $4.24 \pm 0.67$ & $c$ & $1.77 \pm 0.56$ & $a b$ \\
\hline & Shoot & $0.43 \pm 0.02$ & a & $2.43 \pm 0.97$ & $b$ & $4.12 \pm 0.53$ & $b$ & $3.60 \pm 0.72$ & $\mathrm{~b}$ & $0.51 \pm 0.01$ & $c$ \\
\hline & Leaves & $0.39 \pm 0.01$ & a & $0.69 \pm 0.08$ & $\mathrm{~b}$ & $1.56 \pm 0.16$ & c & $1.76 \pm 0.46$ & $\mathrm{c}$ & $0.41 \pm 0.01$ & $\mathrm{a}$ \\
\hline \multicolumn{12}{|l|}{$2000 \mathrm{~m}$ asl } \\
\hline \multirow[t]{3}{*}{ Myrciasp. nov } & $\begin{array}{l}\text { Fine roots } \\
\text { Coarse roots }\end{array}$ & $0.60 \pm 0.10$ & a & $1.05 \pm 0.06$ & a & $1.26 \pm 0.32$ & a & $1.26 \pm 0.26$ & $\mathrm{a}$ & $0.80 \pm 0.11$ & a \\
\hline & Shoot & $0.56 \pm 0.13$ & $\mathrm{a}$ & $0.79 \pm 0.06$ & $\mathrm{a}$ & $0.81 \pm 0.04$ & $\mathrm{a}$ & $1.12 \pm 0.38$ & $\mathrm{a}$ & $0.75 \pm 0.17$ & $\mathrm{a}$ \\
\hline & Leaves & $0.42 \pm 0.02$ & $a$ & $0.69 \pm 0.19$ & a & $0.58 \pm 0.06$ & $a$ & $0.59 \pm 0.06$ & $a$ & $0.42 \pm 0.01$ & $a$ \\
\hline
\end{tabular}


Control Nitrate Ammonium Glycine $\left({ }^{15} \mathrm{~N}\right) \quad$ Glycine $\left({ }^{13} \mathrm{C}\right)$

\begin{tabular}{|c|c|c|c|c|c|c|c|c|c|c|c|}
\hline \multirow[t]{4}{*}{$\begin{array}{l}\text { Hedyosmum } \\
\text { translucidum }\end{array}$} & Fine roots & $0.43 \pm 0.03$ & $a$ & $1.22 \pm 0.11$ & $b$ & $2.44 \pm 0.22$ & C & $2.03 \pm 0.12$ & C & $0.58 \pm 0.03$ & a \\
\hline & Coarse roots & $0.43 \pm 0.02$ & $\mathrm{a}$ & $1.10 \pm 0.11$ & $b c$ & $2.45 \pm 0.20$ & $d$ & $1.56 \pm 0.15$ & c & $0.59 \pm 0.04$ & $a b$ \\
\hline & Shoot & $0.38 \pm 0.00$ & $\mathrm{a}$ & $0.69 \pm 0.05$ & $b$ & $1.28 \pm 0.19$ & c & $1.17 \pm 0.21$ & $\mathrm{bc}$ & $0.41 \pm 0.01$ & $d$ \\
\hline & Leaves & $0.37 \pm 0.00$ & $\mathrm{a}$ & $0.43 \pm 0.01$ & $b$ & $0.59 \pm 0.06$ & $b$ & $0.43 \pm 0.02$ & $b$ & $0.38 \pm 0.00$ & $a$ \\
\hline \multicolumn{12}{|l|}{$3000 \mathrm{~m}$ asl } \\
\hline \multirow[t]{4}{*}{$\begin{array}{l}\text { Graffenrieda } \\
\text { harlingii }\end{array}$} & Fine roots & $0.69 \pm 0.05$ & $\mathrm{a}$ & $1.68 \pm 0.25$ & $a b$ & $2.06 \pm 0.52$ & $a b$ & $2.78 \pm 0.29$ & $b$ & $0.91 \pm 0.12$ & $\mathrm{a}$ \\
\hline & Coarse roots & $0.49 \pm 0.03$ & $\mathrm{a}$ & $1.02 \pm 0.09$ & $b c$ & $1.24 \pm 0.21$ & bc & $1.72 \pm 0.41$ & $b$ & $0.79 \pm 0.17$ & $c$ \\
\hline & Shoot & $0.40 \pm 0.01$ & $\mathrm{a}$ & $0.70 \pm 0.04$ & $\mathrm{~b}$ & $1.18 \pm 0.26$ & $b$ & $2.20 \pm 0.18$ & $c$ & $0.47 \pm 0.01$ & $d$ \\
\hline & Leaves & $0.40 \pm 0.01$ & $\mathrm{a}$ & $0.60 \pm 0.06$ & $b$ & $1.31 \pm 0.38$ & bcd & $1.47 \pm 0.18$ & c & $0.40 \pm 0.00$ & $\mathrm{ad}$ \\
\hline \multirow[t]{4}{*}{$\begin{array}{l}\text { Hedyosmum cf. } \\
\text { purpurascens }\end{array}$} & Fine roots & $0.53 \pm 0.04$ & $a$ & $2.89 \pm 0.75$ & $a b$ & $3.47 \pm 0.69$ & $b$ & $2.92 \pm 0.62$ & $a b$ & $0.68 \pm 0.08$ & \\
\hline & Coarse roots & $0.54 \pm 0.02$ & a & $2.27 \pm 0.62$ & $\mathrm{a}$ & $2.45 \pm 0.19$ & & $1.89 \pm 0.98$ & & $0.82 \pm 0.01$ & \\
\hline & Shoot & $0.40 \pm 0.01$ & $\mathrm{ac}$ & $1.78 \pm 0.82$ & $b$ & $1.90 \pm 0.83$ & $a b$ & $0.92 \pm 0.24$ & $\mathrm{~b}$ & $0.46 \pm 0.00$ & $c$ \\
\hline & Leaves & $0.39 \pm 0.01$ & $\mathrm{a}$ & $0.66 \pm 0.18$ & $b$ & $0.63 \pm 0.11$ & $\mathrm{bc}$ & $0.90 \pm 0.27$ & $b c$ & $0.39 \pm 0.00$ & $\mathrm{ac}$ \\
\hline
\end{tabular}



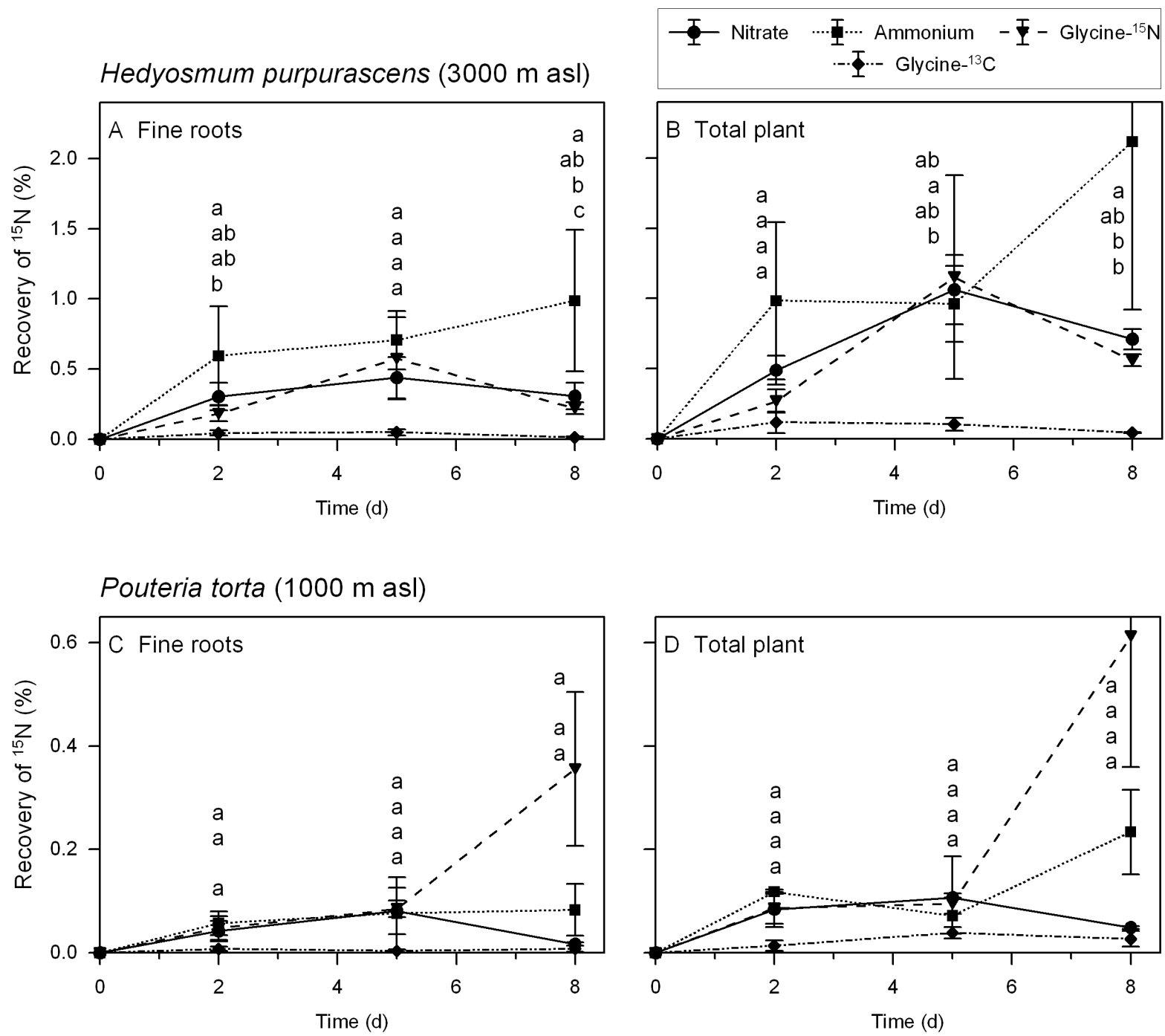

Figure 3. Temporal development of the ${ }^{15} \mathrm{~N}$ content in the fine-root biomass or total plant biomass of saplings of Hedyosmum purpurascens (3000 m asl, upper row) and Pouteria torta (1000 $\mathrm{m}$ asl, lower row) 2, 5 and $8 d$ after application of labelled fertilizer to the soil. The saplings were cultivated in pots and grown outdoor inside the natural forest under a closed forest canopy. The ${ }^{15} \mathrm{~N}$ enrichment in the glycine treatment is presented either as uncorrected value (glycine $-{ }^{15} \mathrm{~N}$ ) or corrected to the amount of ${ }^{13} \mathrm{C}$ accumulated which may indicate uptake of intact glycine molecules (glycine $-{ }^{13} \mathrm{C}$ ). Some saplings (such as all Myrcia saplings) had no coarse roots; consequently, some values and statistics are missing. Different letters indicate significant differences between treatments. $N=3-4$. 
The distribution to different organs of the ${ }^{15} \mathrm{~N}$ accumulated in the plants after $5 \mathrm{~d}$ revealed a considerable variation in $\mathrm{N}$ allocation patterns among the six species and also for the different treatments but no clear elevational trend (Table 3, Figure 4). The species with very low ${ }^{15} \mathrm{~N}$ accumulation, P. torta, accumulated a relatively large proportion of the $\mathrm{N}$ tracer in the fine or coarse roots (nitrate and glycine- ${ }^{15} \mathrm{~N}$ vs. ammonium treatment) with $85-95 \%$ of the ${ }^{15} \mathrm{~N}$ remaining in the below-ground organs. These differences are partly related to species differences in carbon allocation patterns; P. torta and Graffenrieda saplings had a particularly large root biomass (35\% of total, Table 4$)$.

A Nitrate

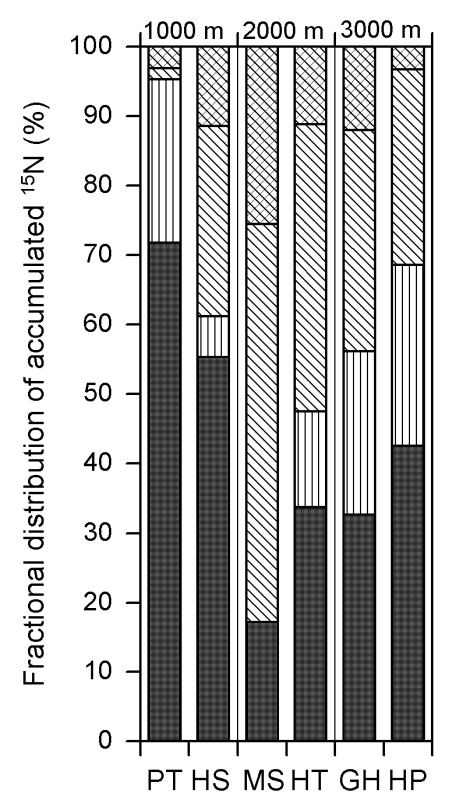

B Ammonium

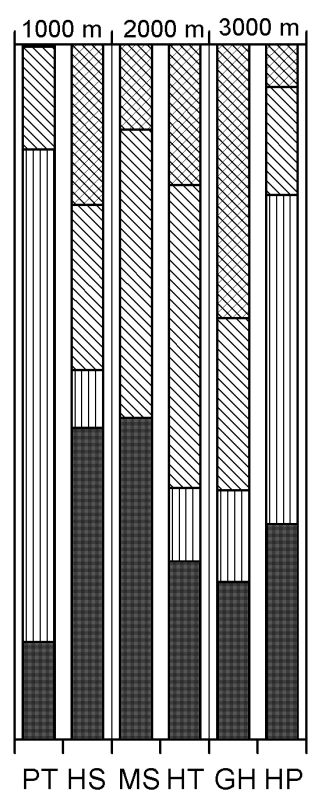

C Glycine $\left({ }^{15} \mathrm{~N}\right)$

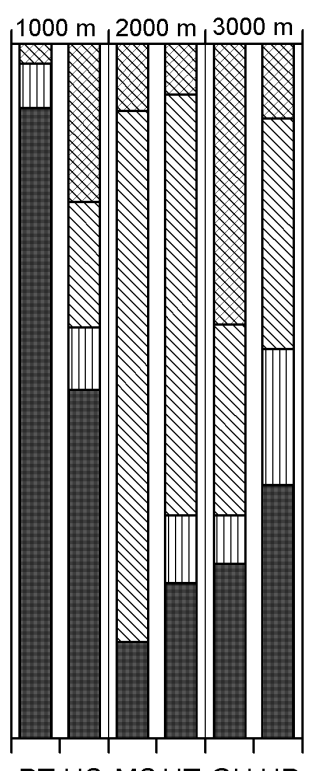

PT HS MSHT GH HP
D Glycine $\left({ }^{13} \mathrm{C}\right)$
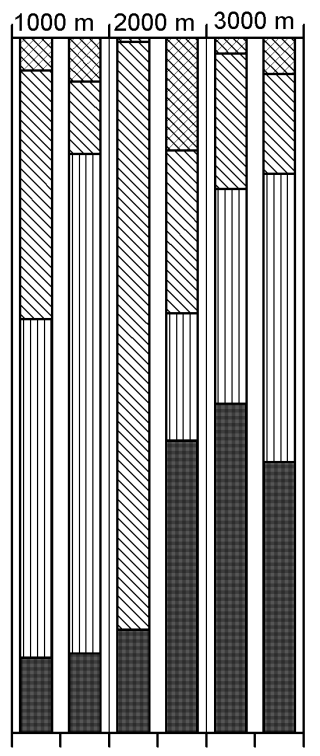

PT HS MSHT GH HP

Leaves Shoot 盂 Coarse roots Fine roots

Figure 4. Distribution to leaves, shoot, coarse and fine roots of ${ }^{15} \mathrm{~N}$ taken up by the plant from labelled nitrate, ammonium or glycine solution (in \% of total ${ }^{15} \mathrm{~N}$ uptake). The ${ }^{15} \mathrm{~N}$ enrichment in the glycine treatment is presented either as uncorrected value $\left(\right.$ glycine $\left.-{ }^{15} \mathrm{~N}\right)$ or corrected to the amount of ${ }^{13} \mathrm{C}$ accumulated which may indicate uptake of intact glycine molecules (glycine $-{ }^{13} \mathrm{C}$ ). Some individuals (such as all Myrcia seedlings) had no coarse roots; consequently, this category is missing here. 
Table 4. Biomass of the saplings at the date of harvest (in $g$ per plant and in $\%$ of total biomass). Some individuals (such as all Myrcia seedlings) had no coarse roots; consequently, values are missing.

\begin{tabular}{|c|c|c|c|c|c|c|}
\hline \multirow{2}{*}{$\begin{array}{l}\text { Elevation } \\
\text { Species }\end{array}$} & \multicolumn{2}{|c|}{$1000 \mathrm{~m}$} & \multicolumn{2}{|c|}{$2000 \mathrm{~m}$} & \multicolumn{2}{|c|}{$3000 \mathrm{~m}$} \\
\hline & Pouteria torta & $\begin{array}{l}\text { Hedyosmum } \\
\text { sprucei }\end{array}$ & $\begin{array}{l}\text { Myrcia sp. } \\
\text { nov. }\end{array}$ & $\begin{array}{l}\text { Hedyosmum } \\
\text { translucidum }\end{array}$ & $\begin{array}{c}\text { Graffenrieda } \\
\text { harlingii }\end{array}$ & $\begin{array}{l}\text { Hedyosmum } \\
\text { purpurascens }\end{array}$ \\
\hline Leaves & $0.37(21 \%)$ & $1.02(43 \%)$ & 0.08 (22\%) & 6.63 (42 \%) & $0.42(21 \%)$ & $0.79(42 \%)$ \\
\hline Shoots & $0.78(44 \%)$ & $0.65(28 \%)$ & $0.25(67 \%)$ & $6.83(44 \%)$ & $0.86(43 \%)$ & $0.57(30 \%)$ \\
\hline Coarse roots & $0.45(26 \%)$ & $0.34(14 \%)$ & & $1.17(7 \%)$ & $0.43(21 \%)$ & $0.29(15 \%)$ \\
\hline Fine roots & $0.16(9 \%)$ & $0.35(15 \%)$ & $0.04(11 \%)$ & $1.00(6 \%)$ & $0.29(14 \%)$ & $0.23(12 \%)$ \\
\hline Plant total & $1.76(100 \%)$ & $2.35(100 \%)$ & $0.37(100 \%)$ & $15.64(100 \%)$ & $2.00(100 \%)$ & $1.87(100 \%)$ \\
\hline
\end{tabular}




\section{Glycine incorporation}

After adding dual-labelled ${ }^{15} \mathrm{~N}^{13} \mathrm{C}$-glycine, much more ${ }^{15} \mathrm{~N}$ was accumulated in the biomass than ${ }^{13} \mathrm{C}$ which resulted in the calculation of much higher apparent glycine uptake rates when considering the ${ }^{15} \mathrm{~N}$ enrichment (glycine- $-{ }^{15} \mathrm{~N}$ calculation) than when calculating with the accumulation of ${ }^{13} \mathrm{C}$ (glycine- ${ }^{13} \mathrm{C}$ approach); the ${ }^{15} \mathrm{~N}$ enrichment was often twofold higher than the corresponding ${ }^{13} \mathrm{C}$ enrichment. The difference between the glycine $-{ }^{15} \mathrm{~N}$ and glycine $-{ }^{13} \mathrm{C}$ values was significant in $\mathrm{H}$. sprucei (all organs), $\mathrm{H}$. translucidum (all organs), G. harlingii (all organs), and $\mathrm{H}$. purpurascens (shoots). An extreme case was the ${ }^{15} \mathrm{~N}$ concentration in the fine-root biomass of $\mathrm{H}$. sprucei which exceeded the ${ }^{13} \mathrm{C}$-concentration nearly ten-fold (Table 3). In contrast, P. torta reached slightly higher glycine uptake rates according to the ${ }^{13} \mathrm{C}$ approach in the shoots and the coarse roots than when calculated through ${ }^{15} \mathrm{~N}$ (glycine- ${ }^{15} \mathrm{~N}$ approach), but all values were very low in this species. All values of apparent glycine uptake according to the ${ }^{13} \mathrm{C}$ approach (glycine $-{ }^{13} \mathrm{C}$ ) were lower than the ${ }^{15} \mathrm{~N}$ content after ${ }^{15} \mathrm{~N}$-nitrate and ${ }^{15} \mathrm{~N}$-ammonium addition. The glycine ${ }^{13} \mathrm{C}$ values were only in a few cases significantly higher than those of the respective control treatment (in $\mathrm{H}$. sprucei and $\mathrm{H}$. translucidum in the shoot, in $\mathrm{G}$. harlingii in the coarse roots and the shoot, and in $\mathrm{H}$. purpurascens in the shoot). Thus, two Hedyosmum species and Graffenrieda exhibited a significantly higher ${ }^{13} \mathrm{C}$ label in at least one plant organ after addition of dual-labelled glycine. Plotting the ${ }^{13} \mathrm{C}_{\text {excess }}$ values against the corresponding ${ }^{15} \mathrm{~N}_{\text {excess }}$ values showed much lower slopes (typically <0.4) than expected for the case of complete glycine incorporation as intact molecule (slope $=$ 2.0) (Table 5 in the Appendix).

A simple addition of the whole-plant uptake rates from the respective ammonium, nitrate and glycine (glycine- ${ }^{13} \mathrm{C}$ approach) experiments may be used for estimating the relative importance of the three $\mathrm{N}$ forms for the nitrogen nutrition of the six species, given that all $\mathrm{N}$ forms were available at similar abundances (Figure 5). Accordingly, 50-60\% would have been taken up as $\mathrm{NH}_{4}{ }^{+}, 20-50 \%$ as $\mathrm{NO}_{3}{ }^{-}$and $5-20 \%$ as glycine in the six species. 


\section{Tracer recovery}

Between $0.02 \%$ and $6.28 \%$ of the added amount of ${ }^{15} \mathrm{~N}$ was recovered in the biomass of the saplings $5 \mathrm{~d}$ after application (Figure 6 and 7). The total amount of ${ }^{15} \mathrm{~N}$ recovered showed no significant preference for either ammonium or nitrate in any of the species. However, $\mathrm{NH}_{4}{ }^{+}$tended to reach a higher accumulation in the total biomass than nitrate in $\mathrm{H}$. sprucei and $\mathrm{H}$. translucidum and in the fine root biomass of all three Hedyosmum species. Similar to the ${ }^{15} \mathrm{~N}$ atom\% values, the mean recovery of ${ }^{15} \mathrm{~N}$ in total biomass was always lower in the glycine $-{ }^{13} \mathrm{C}$ than the glycine $-{ }^{15} \mathrm{~N}$ approach (significant in H. sprucei and G. harlingii).

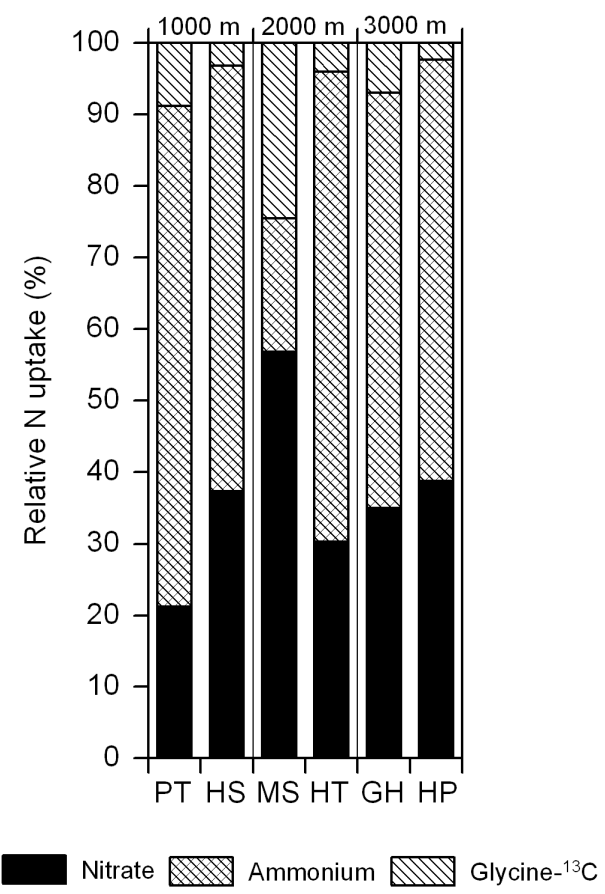

Figure 5. Relative importance of nitrate, ammonium and glycine (calculated with the glycine${ }^{13} \mathrm{C}$ calculation approach) in assumed total $\mathrm{N}$ uptake of the six species if all $\mathrm{N}$ forms were equally available. This calculation is a simple addition of the ${ }^{15} \mathrm{~N}$ incorporation data for ammonium, nitrate and glycine and does not consider interactions among the uptake of the three $N$ forms. 

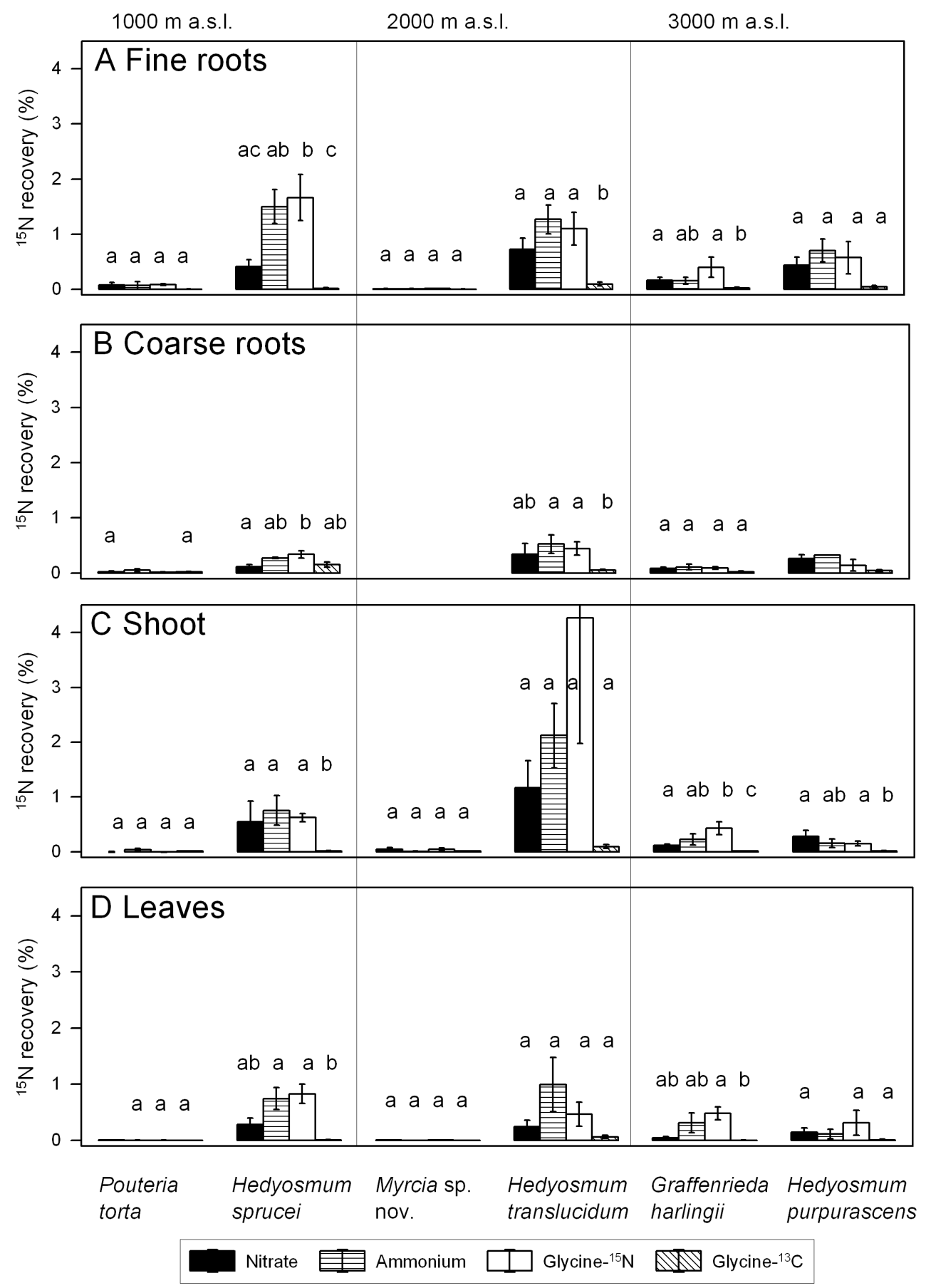

Figure 6. Recovery of ${ }^{15} \mathrm{~N}$ in the biomass of saplings in $\%$ of the ${ }^{15} \mathrm{~N}$ added for the six species in the fine roots $(A)$, coarse roots $(B)$, shoot $(C)$ and leaves $(D)$ five days after labelling with ${ }^{15} \mathrm{~N}$-nitrate, ${ }^{15} \mathrm{~N}$-ammonium, or ${ }^{15} \mathrm{~N}^{13} \mathrm{C}$-glycine (means $\pm S E$ ). The ${ }^{15} \mathrm{~N}$ enrichment in the glycine treatment is presented either as uncorrected value $\left(\right.$ glycine $\left.-{ }^{15} \mathrm{~N}\right)$ or corrected to the amount of ${ }^{13} \mathrm{C}$ accumulated which may indicate uptake of intact glycine 
molecules (glycine ${ }^{13} \mathrm{C}$ ). Some saplings (all Myrcia plants) had no coarse roots; consequently, some values and statistics are missing. Different letters indicate significant differences between treatments within a species.

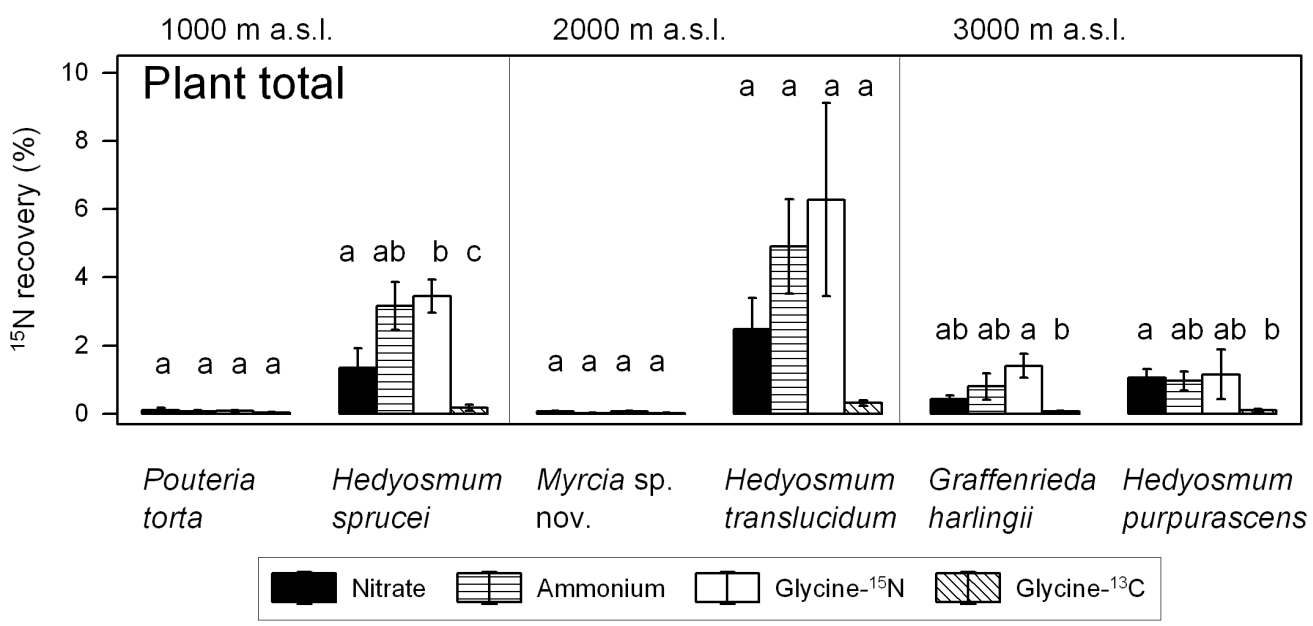

Figure 7. Recovery of ${ }^{15} \mathrm{~N}$ in the biomass of saplings in $\%$ of the ${ }^{15} \mathrm{~N}$ added for the six species in the total plant biomass five days after labelling with ${ }^{15} \mathrm{~N}$-nitrate, ${ }^{15} \mathrm{~N}$-ammonium, or ${ }^{15} \mathrm{~N}^{13} \mathrm{C}$-glycine (means $\pm S E$ ). The ${ }^{15} \mathrm{~N}$ enrichment in the glycine treatment is presented either as uncorrected value (glycine $-{ }^{15} \mathrm{~N}$ ) or corrected to the amount of ${ }^{13} \mathrm{C}$ accumulated which may indicate uptake of intact glycine molecules (glycine $-{ }^{13} \mathrm{C}$ ). Different letters indicate significant differences between treatments within a species. 


\section{Discussion}

The elevation transect in southern Ecuador is characterized by a large decrease in net $\mathrm{N}$ mineralization rate and an even steeper decrease in nitrification rate from 1000 to $3000 \mathrm{~m}$ (Wolf et al. 2011). With mineralization and subsequent nitrification, the upper montane forest receives less than $5 \%$ of the $\mathrm{NH}_{4}{ }^{+}$and less than $1 \%$ of the $\mathrm{NO}_{3}{ }^{-}$of the pre-montane forest. At $1000 \mathrm{~m}$, about $80 \%$ of the $\mathrm{NH}_{4}{ }^{+}$released through mineralization is oxidized to $\mathrm{NO}_{3}^{-}$, while it is only c. $10 \%$ at $3000 \mathrm{~m}$ resulting in increasing dominance of ammonium over nitrate on the cation or anion exchangers in the soil with increasing elevation (c. $80 \%$ of the exchangeable mineral $\mathrm{N}$ pool at 1000 $\mathrm{m}$ and c. $98 \%$ at $3000 \mathrm{~m}$ consists of $\mathrm{NH}_{4}^{+}$). Data on the concentration of dissolved organic $\mathrm{N}$ (DON) show a marked increase from 1000 to $2000 \mathrm{~m}$ with growing humus layer thickness. At $2000 \mathrm{~m}$, Goller et al. (2006) found $50 \%-70 \%$ of the soil solution N to be DON and $27 \%-43 \% \mathrm{NH}_{4}^{+}$; only $3 \%-5 \%$ referred to $\mathrm{NO}_{3}{ }^{-}$. As $\mathrm{DON}$ is released from soil organic matter mainly by microbial degradation (Guggenberger et al. 1994, Michalzik et al. 2001, Uselman et al. 2012), the DON fraction should increase in importance with increasing organic matter content of the soil. Thus, we expected that the relative abundance of organic $\mathrm{N}$ compounds and of ammonium both should increase with elevation at the expense of nitrate.

The great dominance of $\mathrm{DON}$ and $\mathrm{NH}_{4}{ }^{+}$over $\mathrm{NO}_{3}{ }^{-}$in the soils at 2000 and at $3000 \mathrm{~m}$ is only partly reflected in the $\mathrm{N}$ form preference of the investigated tree species. Only one of the four species from 2000 and $3000 \mathrm{~m}$ (H. translucidum) took up ammonium more rapidly than nitrate when both $\mathrm{N}$ forms were equally available. Another species (G. harlingii) showed a tendency for $\mathrm{NH}_{4}{ }^{+}$preference but the ${ }^{15} \mathrm{~N}$ accumulation from added ammonium was not significantly higher than that from nitrate in any of the organs examined. At $1000 \mathrm{~m}$ with a higher abundance of nitrate in the soil, one species $\left(H\right.$. sprucei) seemed to prefer $\mathrm{NH}_{4}{ }^{+}$over $\mathrm{NO}_{3}{ }^{-}$, but the other species showed no difference in the uptake of nitrate and ammonium. Thus, our data from six relatively abundant montane forest tree species indicate that there seem to be species-specific differences in the $\mathrm{N}$ form preference but they were not related to the 
abundance of ammonium and nitrate in the soil and thus apparently independent from elevation. While no species seemed to prefer $\mathrm{NO}_{3}{ }^{-}$over $\mathrm{NH}_{4}{ }^{+}$, we found apparent ammonium preference in a minority of tree species, in particular the species with highest sapling growth rates (unpubl. data). It must be kept in mind that experiments adding different $\mathrm{N}$ forms at equal concentrations (as done here) may not reflect actual $\mathrm{N}$ form preferences in the stands because the three forms occurred at very different abundances which could influence root uptake kinetics. Nevertheless, it appears that balanced uptake of $\mathrm{NH}_{4}{ }^{+}$and $\mathrm{NO}_{3}{ }^{-}$seems to be preferred by the majority of species when both $\mathrm{N}$ forms are equally available. A similar conclusion was drawn from ${ }^{15} \mathrm{~N}$-uptake experiments in a five-species temperate broad-leaved forest by Jacob \& Leuschner (2014). The existing two N-uptake studies for tropical rainforest plants reported a higher ammonium than nitrate uptake in three hemiepiphytic Clusia species (Wanek et al. 2002) and no preferences for ammonium or nitrate for understorey palms (Andersen \& Turner 2013).

Indirect evidence for differences in the use of ammonium or nitrate in tropical forests may be derived from the $\delta^{15} \mathrm{~N}$ signature of foliage and soil. Brearley (2012) concluded that the trees of a montane forest on acidic soil in Jamaica must prefer $\mathrm{NH}_{4}{ }^{+}$over $\mathrm{NO}_{3}{ }^{-}$due to the isotopic similarity between the leaf and bulk soil signatures. In our transect, the altitudinal decrease in bulk soil $\delta^{15} \mathrm{~N}$ from 1000 to $3000 \mathrm{~m}$ matches well with the measured decrease in mineralization and nitrification rates along the slope and the very low nitrate availability at high elevations. However, low foliar $\delta^{15} \mathrm{~N}$ values in the trees at $3000 \mathrm{~m}$ in our study should not be mistaken as indication of $\mathrm{NH}_{4}{ }^{+}$preference; in fact, the uptake experiments showed that nitrate and ammonium were incorporated at roughly similar rates by the two species from this elevation. It should be noted that the soil chemical conditions measured at 1000, 2000 and $3000 \mathrm{~m}$ in the stands (see Table 1) are not necessarily exactly those established in the pots, even though we used local soil.

Our data from dual-labeling provide some evidence that intact glycine molecules are used as an additional $\mathrm{N}$ source by certain montane forest species and that this capability is not restricted to ECM species. According to the ${ }^{13} \mathrm{C}$ incorporation data of 114 
the glycine $-{ }^{13} \mathrm{C}$ calculation approach, glycine skeletons showed a significant accumulation relative to the control in at least one plant organ in three species $(H$. sprucei, $H$. translucidum and $G$. harlingii), with the first two species having exclusively $A M$, the latter ECM and AM symbionts.

The amount of ${ }^{15} \mathrm{~N}$ incorporated in the biomass after feeding with labelled glycine was in most cases similar to the ${ }^{15} \mathrm{~N}$ accumulation after ammonium addition and typically exceeded the ${ }^{15} \mathrm{~N}$ incorporation from glycine as derived from the ${ }^{13} \mathrm{C}$ data by factors of two to four. This is expressed by very small slopes (typically <0.4) of the regression line ${ }^{13} \mathrm{C}_{\text {excess }}$ vs. ${ }^{15} \mathrm{~N}_{\text {excess }}$ values in the biomass of the plants (see Table 5 in the Appendix). This discrepancy suggests that much of the glycine has been deaminated in the soil in the $5 \mathrm{~d}$ before harvest and that most ${ }^{15} \mathrm{~N}$ was subsequently taken up as $\mathrm{NH}_{4}^{+}$or $\mathrm{NO}_{3}^{-}$. The glycine ${ }^{15} \mathrm{~N}$ calculation should therefore largely overestimate glycine uptake while the ${ }^{13} \mathrm{C}$-based calculation must reflect the minimum uptake of intact glycine because part of the accumulated $\mathrm{C}$ skeletons may already have been lost via respired ${ }^{13} \mathrm{CO}_{2}$ in the days after the start of the experiment. Our results suggest that ${ }^{15} \mathrm{~N}$ tracer studies on the uptake of organic $\mathrm{N}$ in the tropics using single-labelled glycine as the study on understorey palms in a lower montane forest in Panama by Andersen \& Turner (2013) might largely overestimate the actual uptake of organic N. Studies with dual-labeled amino acids as conducted here also have been criticized for possible shortcomings such as possible uptake of labelled inorganic C through the roots (e.g. Rasmussen \& Kuzyakov 2009). Therefore, our findings can only be a first step towards a proof of the use of intact organic $\mathrm{N}$ sources in tropical trees. The decreasing ${ }^{13} \mathrm{C}$ content in the biomass of $H$. purpurascens after day 5 of the experiment (Figure 4) may relate to respirative $\mathrm{C}$ losses. Our data are not comprehensive enough to prove an altitudinal increase in the use of glycine as it was found in the tree species of a temperate mountain by Averill \& Finzi (2011).

One of the factors that could lead to contrasting $\mathrm{N}$ uptake rates and differences in $\mathrm{N}$ form preference among the co-occurring tree species of a species-rich tropical forest is phenology. Two species of our sample ( $P$. torta at $1000 \mathrm{~m}$ and the unnamed Myrcia 
species at $2000 \mathrm{~m}$ ) showed only poor sapling growth in the experiment and the plants accumulated only very small amounts of ${ }^{15} \mathrm{~N}$ from the added tracer which made it impossible to detect preferences for certain $\mathrm{N}$ forms. Pouteria torta shows leaf flushing in January and February and reduces growth thereafter with presumably reduced $\mathrm{N}$ demand. This species and also the Myrcia species are typical latesuccessional trees with normally slower growth than more light-demanding species. The small fine- and coarse-root systems of the two species may be related to the generally slow growth rates which are a likely explanation of the low $\mathrm{N}$ uptake of these species.

Future studies on $\mathrm{N}$ uptake patterns in species-rich tropical forests should examine possible relationships between light demand, growth rate, type of mycorrhiza and $\mathrm{N}$ uptake capacity and $\mathrm{N}$-form preference among the co-occurring species. Relationships between these traits may only become visible when a much larger number of species is investigated. Further, the study of organic $\mathrm{N}$ use should be extended to include other larger and charged amino acid species as well.

\section{Conclusions}

Our knowledge about the nitrogen uptake capacity and $\mathrm{N}$ form preference of tropical montane forest trees is rudimentary. This study with six tree species provides some of the first information on uptake rates into fine roots and the whole plant under field conditions, on possible preferences for ammonium or nitrate, and on the role of organic $\mathrm{N}$ (glycine) for the $\mathrm{N}$ nutrition of trees. Despite the large decrease in $\mathrm{N}$ supply rate from 1000 to $3000 \mathrm{~m}$ asl, we found no indication of an altitudinal shift in $\mathrm{N}$-form preference. Future studies in a larger number of tree species should search for more profound evidence (e.g. through triple-labeling of amino acids) that organic $\mathrm{N}$ indeed is playing a significant role in the $\mathrm{N}$ nutrition of these forests on humus-rich cool soils, and how uptake rates are dependent on tree functional traits and mycorrhiza type. In 
addition, this could lead to a better understanding of the importance of phylogeny versus elevation in the $\mathrm{N}$ nutrition of tropical trees.

\section{Acknowledgements}

We thank Katrin Wolf for data on the $\delta^{15} \mathrm{~N}$ signature of tree leaves and Angelica Baldos (both at Department of Tropical Soil Science, University of Göttingen) for data on salt-extractable concentrations of organic N. We are also grateful to AlzChem Trostberg $\mathrm{GmbH}$, Trostberg, Germany for supplying us with dicyandiamide. The authors are indebted to the German Academic Exchange Service (DAAD) for funding part of the field work and the DFG (FOR 816, subproject A2.2) for financial support. Logistic support by the Foundation Nature and Culture International ( $\mathrm{NCl}$, San Diego - Loja) is gratefully acknowledged. We thank the Ministerio del Ambiente de Ecuador for the research permit. 


\section{Literature cited}

ANDERSEN, K. M. \& TURNER, B. L. 2013. Preferences or plasticity in nitrogen acquisition by understorey palms in a tropical montane forest. Journal of Ecology 101:819-825.

ARNDT, S. K., WANEK, W., HOCH, G., RICHTER, A. \& POPP, M. 2002. Flexibility of nitrogen metabolism in the tropical C3-crassulacean acid metabolism tree species Clusia minor. Functional Plant Biology 29:741-747.

AVERILL, C. \& FINZI, A. 2011. Increasing plant use of organic nitrogen with elevation is reflected in nitrogen uptake rates and ecosystem $\delta^{15} \mathrm{~N}$. Ecology 92:883891.

BENDIX, J., HOMEIER, J., CUEVA ORTIZ, E., EMCK, P., BRECKLE, S.-W., RICHTER, M. \& BECK, E. 2006. Seasonality of weather and tree phenology in a tropical evergreen mountain rain forest. International Journal of Biometeorology 50:370-384.

BREARLEY, F. Q. 2012. Nitrogen stable isotopes indicate differences in nitrogen cycling between two contrasting Jamaican montane forests. Plant and Soil 367:465-476.

DI, H. J. \& CAMERON, K. C. 2004. Effects of temperature and application rate of a nitrification inhibitor, dicyandiamide (DCD), on nitrification rate and microbial biomass in a grazed pasture soil. Australian Journal of Soil Research 42:927932.

FINZI, A. C. \& BERTHRONG, S. T. 2005. The uptake of amino acids by microbes and trees in three cold-temperate forests. Ecology 86:3345-3353.

GOLLER, R., WILCKE, W., FLEISCHBEIN, K., VALAREZO, C. \& ZECH, W. 2006. Dissolved nitrogen, phosphorus, and sulfur forms in the ecosystem fluxes of a montane forest in Ecuador. Biogeochemistry 77:57-89.

GRAEFE, S., LEUSCHNER, C., CONERS, H. \& HERTEL, D. 2011. Root functioning in tropical high-elevation forests: Environmental vs. biological control of root water absorption. Environmental and Experimental Botany 71:329-336.

GUGGENBERGER, G., ZECH, W. \& SCHULTEN, H.-R. 1994. Formation and mobilization pathways of dissolved organic matter: evidence from chemical structural studies of organic matter fractions in acid forest floor solutions. Organic Geochemistry 21:51-66.

HOMEIER, J., WERNER, F. A., GRADSTEIN, S. R., BRECKLE, S.-W. \& RICHTER, M. 2008 Potential vegetation and floristic composition of Andean forests in South Ecuador, with a focus on the RBSF. Pp. 87-100 in BECK, E., BENDIX, J., KOTTKE, I., MAKESCHIN, F. \& MOSANDL, R. (eds.). Gradients in a 
Tropical Mountain Ecosystem of Ecuador. Ecological Studies Vol. 198, Springer Verlag, Berlin, Heidelberg, New York.

JACOB, A., LEUSCHNER, C. 2014. Complementarity in the use of nitrogen forms in temperate broad-leaved mixed forest. Plant Ecology and Diversity, in press.

JONES, D. L., KIELLAND, K., SINCLAIR, F. L., DAHLGREN, R. A., NEWSHAM, K. K., FARRAR, J. F. \& MURPHY, D. V. 2009. Soil organic nitrogen mineralization across a global latitudinal gradient. Global Biogeochemical Cycles 23.

KIELLAND, K. 1994. Amino acid absorption by arctic plants: implications for plant nutrition and nitrogen cycling. Ecology 75:2373.

KIELLAND K. 1997. Role of free amino acids in the nitrogen economy of arctic cryptogams.

Ecoscience 4:75-79.

KOTTKE, I., BECK, A., OBERWINKLER, F., HOMEIER, J. \& NEILL, D. 2004. Arbuscular endomycorrhizas are dominant in the organic soil of a neotropical montane cloud forest. Journal of Tropical Ecology 20:125-129.

MARRS, R. H., PROCTOR, J., HEANEY, A. \& MOUNTFORD, M. D. 1988. Changes in soil nitrogen-mineralization and nitrification along an altitudinal transect in tropical rain forest in Costa Rica. Journal of Ecology 76:466-482.

MICHALZIK, B., KALBITZ, K., PARK, J.-H., SOLINGER, S. \& MATZNER, E. 2001. Fluxes and concentrations of dissolved organic carbon and nitrogen-a synthesis for temperate forests. Biogeochemistry 52:173-205.

MOSER, G., HERTEL, D. \& LEUSCHNER, C. 2007. Altitudinal change in LAI and stand leaf biomass in tropical montane forests: a transect study in Ecuador and a pan-tropical meta-analysis. Ecosystems 10:924-935.

MOSER, G., LEUSCHNER, C., HERTEL, D., GRAEFE, S., SOETHE, N. \& IOST, S. 2011. Elevation effects on the carbon budget of tropical mountain forests (S Ecuador): the role of the belowground compartment. Global Change Biology 17:2211-2226.

NÄSHOLM, T. \& PERSSON, J. 2001. Plant acquisition of organic nitrogen in boreal forests. Physiologia Plantarum 111:419-426.

NÄSHOLM, T., EKBLAD, A., NORDIN, A., GIESLER, R., HÖGBERG, M. \& HÖGBERG, P. 1998. Boreal forest plants take up organic nitrogen. Nature 392:914-916.

PAOLI, G. D., CURRAN, L. M. \& ZAK, D. R. 2005. Phosphorus efficiency of Bornean rain forest productivity: Evidence against the unimodal efficiency hypothesis. Ecology 86:1548-1561.

RASMUSSEN, J. \& KUZYAKOV, Y. 2009. Carbon isotopes as proof for plant uptake 
of organic nitrogen: Relevance of inorganic carbon uptake. Soil Biology and Biochemistry 41:1586-1587.

TANNER, E. V. J. 1981. The decomposition of leaf litter in Jamaican montane rain forests. Journal of Ecology 69:263-275.

TANNER, E. V. J., VITOUSEK, P. M. \& CUEVAS, E. 1998. Experimental investigation of nutrient limitation of forest growth on wet tropical mountains. Ecology 79:10-22.

USELMAN, S. M., QUALLS, R. G. \& LILIENFEIN, J. 2012. Quality of soluble organic $\mathrm{C}, \mathrm{N}$, and $\mathrm{P}$ produced by different types and species of litter: Root litter versus leaf litter. Soil Biology and Biochemistry 54:57-67.

VERMA, A., TYAGI, L. \& SINGH, S. N. 2007. Attenuation of $\mathrm{N}_{2} \mathrm{O}$ emission rates from agricultural soil at different dicyandiamide concentrations. Environmental Monitoring and Assessment 137:287-293.

VITOUSEK, P. M. \& SANFORD, R. L. 1986. Nutrient cycling in moist tropical forest. Annual Review of Ecology and Systematics 17:137-167.

WANEK, W., ARNDT, S. K., HUBER, W. \& POPP, M. 2002. Nitrogen nutrition during ontogeny of hemiepiphytic Clusia species. Functional Plant Biology 29:733740 .

WANEK, W. \& PÖRTL, K. 2008. Short-term ${ }^{15} \mathrm{~N}$ uptake kinetics and nitrogen nutrition of bryophytes in a lowland rainforest, Costa Rica. Functional Plant Biology 35:51-62.

WITTICH, B, HORNA, V., HOMEIER, J. \& LEUSCHNER, C. 2012. Altitudinal change in the photosynthetic capacity of tropical trees - a case study from Ecuador and a pantropical literature analysis. Ecosystems 15:958-973.

WOLF, K., VELDKAMP, E., HOMEIER, J. \& MARTINSON, G. O. 2011. Nitrogen availability links forest productivity, soil nitrous oxide and nitric oxide fluxes of a tropical montane forest in southern Ecuador. Global Biogeochemical Cycles 25, GB4009, doi:10.1029/2010GB003876, 2011.

.ZACHERL, B. \& AMBERGER, A. 1990. Effect of the nitrification inhibitors dicyandiamide, nitrapyrin and thiourea on Nitrosomonas europaea. Fertilizer Research 22:37-44. 
CHAPTER 5

Synthesis 


\section{Background}

In tropical moist forests, nitrogen availability is an important factor regarding forest productivity but, in the lowlands, often not limiting. Most tropical lowland forests are supposed to be phosphorus limited (Paoli et al., 2005; Tanner et al., 1998). In montane tropical forests, nitrogen limitation should become more crucial with elevation, mainly, due to reduced decomposition and mineralization rates and, therefore, lower availability of nitrogen for plants at higher altitudes. Moreover, reduced decomposition rates at higher altitudes lead to thicker organic soil layers and a change in available nitrogen forms from mostly inorganic at low elevations to mostly organic at high elevations (Wolf et al., 2011). However, the knowledge about the preference of tropical trees for different nitrogen forms is very limited and, to date, it remains an unanswered question, if tropical trees are able to take up significant amounts of organic nitrogen and how they adapt to different nitrogen forms being available at different altitudes.

Nitrogen availability along elevational gradients in tropical montane forests should also have an effect on the photosynthetic capacity of trees which is related to foliar nitrogen content mainly because of the high nitrogen demand for the proteins of the Calvin cycle and thylakoids which represent the majority of foliar nitrogen (Evans, 1989). Other possible factors controlling photosynthetic capacity which change along altitudinal gradients are the availability of phosphorus, temperature, the partial pressure of $\mathrm{CO}_{2}\left[\mathrm{CO}_{2}\right]$, VPD and radiation.

The study was conducted in three forest stands at 1000, 2000 and $3000 \mathrm{~m}$ elevation and aimed at answering the following main questions:

(1) How is the photosynthetic capacity of tropical trees affected by altitude?

(2) Which factors are controlling the photosynthetic capacity of tropical trees along altitudinal transects? 
(3) Does the preference for different nitrogen forms of tropical tree saplings change with altitude?

\section{Photosynthetic capacity as affected by altitude}

With increasing elevation trees have to cope with changes in environmental conditions that should lead to decreasing photosynthetic capacities, mainly reduced temperatures, reduced $\left[\mathrm{CO}_{2}\right]$, reduced availability of nutrients and reduced VPD and radiation due to increased cloudiness (Angert, 2006; Körner, 2007). Trees adapt to these environmental conditions by changes in leaf morphology and physiology (Cordell et al., 1999) to maintain photosynthetic capacities as high as under the more favourable conditions in the lowlands. In a study on gas exchange of mature trees, we found light saturated net photosynthesis at ambient temperatures and $\left[\mathrm{CO}_{2}\right]\left(\mathrm{A}_{\mathrm{sat}}\right)$ in the lower, pre-montane stand to be only slightly decreased compared to tropical lowland forests (e.g. Reich et al., 1999; Santiago and Wright, 2007; Santiago et al., 2004) with a mean $A_{\text {sat }}$ of $8.8 \mu \mathrm{mol} \mathrm{CO}_{2} \mathrm{~m}^{-2} \mathrm{~s}^{-1}$ for 15 tree species. When moving $2000 \mathrm{~m}$ in upslope direction, we measured a slightly lower mean $\mathrm{A}_{\mathrm{sat}}$ of $7.2 \mu \mathrm{mol} \mathrm{CO}_{2}$ $\mathrm{m}^{-2} \mathrm{~s}^{-1}$ for 10 tree species at $3000 \mathrm{~m}$. Hence, the trees in the studied montane forests seem to nearly have compensated for the decreasing temperatures $(-10 \mathrm{~K})$ and other changes in environmental conditions along the elevational gradient and to have maintained a photosynthetic capacity at $3000 \mathrm{~m}$ elevation almost as high as that at $1000 \mathrm{~m}$. Similar to $A_{\text {sat }}$, no significant altitudinal trend was observed for leaf dark respiration $\left(R_{D}\right)$.

However, $A_{\text {sat }}$ measured at mid-elevation did not fit into this pattern of a constant or slightly decreasing photosynthetic capacity with elevation due to less favourable environmental conditions and compensation strategies of the tree species. In contrast, $A_{\text {sat }}$ at 2000 m elevation was significantly increased (mean $A_{\text {sat }}$ of $11.3 \mu \mathrm{mol}$ $\mathrm{CO}_{2} \mathrm{~m}^{-2} \mathrm{~s}^{-1}$ for 16 tree species) compared to both, the premontane forest at $1000 \mathrm{~m}$ and the upper montane forest at $3000 \mathrm{~m}$. 
The mid-elevation site of the elevational gradient studied in this thesis is characterized by high nitrogen and phosphorus availabilities and high foliar phosphorus and nitrogen contents per mass (Wolf et al., 2011). In addition, the very high foliar phosphorous and nitrogen contents of the tree individuals measured in this study might be a consequence of choosing many fast growing tree species with good nutrient supply at this site due to access restrictions.

Phosphorus, as well as nitrogen, is needed by plants to build the photosynthetic apparatus and to guarantee the availability of energy in form of ATP for leaf metabolism (Warren, 2011). Hence, a high photosynthetic capacity of leaves demands high foliar nitrogen and phosphorus contents. The mid-elevation site has furthermore the lowest annual precipitation of all three sites and a soil $\mathrm{pH}$ that tends to be higher compared to the other sites (Moser et al., 2007; Wolf et al., 2011). It can be assumed that site-specific conditions added to the influence of altitude on photosynthetic capacity, leading to an increased $A_{\text {sat }}$ at mid-elevation.

We put the data on photosynthesis as affected by altitude acquired in a South Ecuadorian montane moist forest into the broader context of a pan-tropical literature survey for $A_{\text {sat }}$ of mature tropical trees of c. 170 species in 25 stands located at elevations between 100 and $3700 \mathrm{~m}$. According to the literature survey, $A_{\text {sat }}$ decreases by $1.3 \mu \mathrm{mol} \mathrm{CO}_{2} \mathrm{~m}^{-2} \mathrm{~s}^{-1}$ per $\mathrm{km}$ altitude increase. $A_{\text {sat }}$ decreased in spite of decreasing SLA with altitude, indicating that tropical trees are not able to compensate completely for less favourable environmental conditions with increasing elevation by changes in leaf morphology and physiology.

The data on photosynthetic rates of the leaves at ambient temperatures and $\left[\mathrm{CO}_{2}\right]$ combined with data on leaf area index (LAI) (Moser et al., 2007) could be used to calculate annual gross photosynthesis at stand-level (Leuschner et al., 2013). Gross photosynthesis was estimated at 12.5 to $27.2 \mathrm{Mg} \mathrm{C} \mathrm{ha}^{-1} \mathrm{yr}^{-1}$ and was considerably reduced from 2000 to $3000 \mathrm{~m}$ elevation due to markedly decreasing photosynthetic capacities and LAI. This was accompanied by a decrease of autotrophic respiration, which may be linked to reduced growth rates, and a decrease of heterotrophic 
respiration, slowing down decomposition and mineralisation. Leuschner et al. (2013) concluded that canopy carbon gain decreases largely with elevation in this tropical montane forest.

However, it should be considered that $A_{\text {sat }}$ for shade leaves was not measured directly but estimated from the $A_{\text {sat }}$ values of sun leaves. Furthermore, the measured sun leaves were accessed from the ground and, even if we measured only leaves that were exposed to full sun light at least part of the day, we cannot exclude the possibility that measurements of sun leaves from the upper part of the canopies would lead to higher $A_{\text {sat }}$ values. Measurements of clear sun and additionally of clear shade leaves should improve the estimates of stand level gross photosynthesis, especially at 1000 and 2000 m elevation, were shade leaves constitute the biggest part of the canopies.

Moreover, the coefficients of among-species variation in $A_{s a t}$ and $R_{D}$ of our study in South Ecuador accounted for 20 to $53 \%$. The 40 studied species represent only $5 \%$ of the c. 800 tree species abundant in the study region and even the c. 170 species of the literature survey represent only a tiny number of the approximately 37000 woody taxa in the tropics (Odegaard, 2000). For a better understanding of the photosynthesis of tropical trees as affected by altitude, more species at different elevations should be studied. Choosing the studied tree species according to their dominance in a stand and differentiating between early successional and late successional species should give us a more accurate and detailed picture of the photosynthetic capacity of tropical trees.

\section{Effect of temperature, partial pressure of $\mathrm{CO}_{2}$ and nutrient availability on photosynthesis}

A variety of environmental factors that change along elevational gradients, may limit photosynthetic capacity $\left(A_{\max }\right)$ in tropical montane forests (Letts et al., 2011). With increasing elevation, trees must try to maintain sufficient rates of photosynthesis in 
spite of less favourable abiotic conditions such as decreasing temperature and $\left[\mathrm{CO}_{2}\right]$ and biotic factors as varying specific leaf area (SLA), foliar nitrogen and phosphorus content and wood specific gravity. Gas exchange measurements on 40 species of mature forest trees showed no altitudinal trend of $A_{\max }$ and $R_{D}$ at ambient conditions, but $A_{\max }$ tended to be lowest in the stand at the highest elevation. When standardized to $25^{\circ} \mathrm{C}$ at all sites, $A_{\max }$ and $R_{D}$ increased with elevation. Thus, $A_{\max }$ showed partial and $R_{D}$ full homeostatic adjustment to adverse environmental conditions at higher elevations. Surprisingly, the maximum electron transport rate $J_{\max }$ increased with elevation even at ambient conditions possibly as a response to increased cloudiness at high elevations (Van de Weg et al., 2009). Along the elevational gradient, mass based foliar phosphorous content $\left(P_{m}\right)$ was the most important factor influencing variations in $A_{\max }$ while foliar nitrogen, temperature and partial pressure of $\mathrm{CO}_{2}$ had no effect on $A_{\max }$. However, foliar nitrogen and temperature are probably influencing $A_{\max }$ indirectly through reduced leaf area. At high elevations, we saw a pronounced reduction in SLA but no increase in carboxylation efficiency. Hence, carbon gain at high elevations in tropical montane forests is probably influenced to a greater extend by reduced SLA and canopy leaf area than by adaptive modifications of leaf physiology and the photosynthetic apparatus.

Leaf dark respiration per leaf area seemed to remain constant with elevation due to the decrease of SLA. In contrast, stem and coarse root respiration decreased with elevation along the same altitudinal gradient in South Ecuador (Zach et al., 2008). Leuschner et al. (2013) concluded that temperature is influencing gross primary production and net primary production along the altitudinal gradient in South Ecuador directly and indirectly, with a decrease of autotrophic respiration, which may be linked to reduced growth rates, and a decrease of heterotrophic respiration, slowing down decomposition and mineralization. Nitrogen availability seems to influence gross primary production and net primary production mainly through a restriction of leaf area expansion with elevation (reduced $\mathrm{N}$ supply with decreasing temperature) which limits carbon gain in high altitudes (Leuschner et al., 2013).

Letts et al. (2011) studied $A_{\max }$ and various environmental factors along an elevational 126 
gradient in Colombia. They assumed cloudiness to be the most important factor influencing $A_{\max }$ with increased cloudiness reducing the photosynthetic capacity of tropical tree species by decreased radiation and increased surface wetness of the leaves.

The effect of environmental factors on photosynthetic capacity might be dependent on geology, climate and the abundant tree species of a stand. From the results of our study on gas exchange in South Ecuador, we would expect $A_{\max }$ to decline with increasing elevation along elevational gradients with reduced phosphorous availabilities at high elevations and to show little or no altitudinal decline at slopes with good phosphorous supply at high elevations. Further studies should address the question if the effect of phosphorous on $A_{\max }$ is valid for other tropical mountains than the slope monitored in South Ecuador as well as the direct and indirect effects of nitrogen availability and temperature on $A_{\max }$. A possibility would be the comparison of the development of $A_{\max }$ with elevation on slopes with young volcanic ash soils that are rich in allophanes and on slopes with acidic soils which have a low phosphorous availability. Gas exchange measurements on tropical montane forest trees in nutrient manipulation experiments could lead to a better understanding of the influence of nutrients on variations in $A_{\max }$.

\section{Altitude effects on the preference for different nitrogen forms}

As tropical montane forests accumulate thick organic layers with increasing elevation (Moser et al. 2011; Wolf et al., 2011), one would expect that tropical tree species adapt to the high abundance of organic nitrogen forms at high elevations by developing the ability to take up organic nitrogen. However, most tropical tree species are supposed to form arbuscular mycorrhiza (AM), with ectomycorrhyzal (ECM) species being rather rare (Kottke et al., 2004). AM fungi are generally thought to lack the proteolytic capacity that was found in ECM species (Chalot and Brun, 1998) and thus to be more effective in capturing inorganic than organic nitrogen. $A{ }^{15} \mathrm{~N}-{ }^{13} \mathrm{C}$ - 
tracer study, conducted with tree sapling of two species each at 1000, 2000 and 3000 $\mathrm{m}$ elevation fertilized with labelled ammonium, nitrate and glycine, confirmed this assumption, as three of the six species were able to take up organic nitrogen in form of glycine, one being a ECM species (3000 m), two being AM species (1000 and $2000 \mathrm{~m}$ ). As the ${ }^{13} \mathrm{C}$ enrichment in a plant after fertilization with double-labelled glycine indicates the synchronous uptake of the $C$ skeleton and the amino group of the glycine molecule, the ${ }^{13} \mathrm{C}$-enrichment in the saplings can be regarded as a good measurement for the minimum uptake of glycine.

The preference for a certain nitrogen form seems to be altitude-independent and thus independent of the abundance of different nitrogen forms in the soil. Of the six tree species, two species preferred ammonium over nitrate (at 1000 and $2000 \mathrm{~m}$ ), and four species took up nitrate and ammonium at similar rates. In spite of a very steep decrease of net nitrogen mineralization rate and nitrification rate along the elevational gradient (Wolf et al., 2011) and a generally very low nitrate content of the soil solution nitrogen (3-5\% at the mid-elevation site, Goller et al., 2006), species at all elevations seem to take up nitrate to a rather high extent when supplied with it. Tree seedlings of tropical lowland Clusia species have been shown to take up nitrogen from nitrate, ammonium and glycine as well, but to prefer ammonium (Arndt et al., 2002; Wanek et al., 2002).

The analysis of the $\delta^{15} \mathrm{~N}$-contents in the leaves of mature trees and in the organic soil layers and the mineral soil at the three sites yielded decreasing $\delta^{15} \mathrm{~N}$-values with elevation in all three compartments but most pronounced in the leaves, leading to an increasing $\Delta \delta^{15} \mathrm{~N}$ - value between leaves and soil (difference $\delta^{15} \mathrm{~N}_{\text {plant }}-\delta^{15} \mathrm{~N}_{\text {soil }}$ ) that could be indicating a more pronounced uptake of ammonium compared to nitrate (Amundson, 2003; Craine et al., 2009). As our tracer study showed no increasing preference for ammonium with altitude, increasing $\Delta \delta^{15} \mathrm{~N}$ - values probably are a consequence of decreasing nitrate availability with elevation instead.

Leuschner et al (2013) concluded from an up-slope reduction of fine root respiration in spite of a large increase in standing fine root biomass at the altitudinal gradient in 
South Ecuador that trees at high altitudes should have much reduced nutrient uptake activities of their fine roots compared to the trees at lower altitudes. Reduced nitrogen uptake activities with altitude were not visible in our experiment with the lowest uptake of nitrogen per biomass at $1000 \mathrm{~m}$ (Pouteria) and $2000 \mathrm{~m}$ (Myrcia) and the highest uptake of nitrogen at $1000 \mathrm{~m}$ elevation (H. sprucei). In a nutrient manipulation experiment at the study site at $2000 \mathrm{~m}$ elevation, mature trees of Myrcia sp. tended to reduce growth upon nitrogen and phosphorus fertilization (Homeier et al., 2012).

The six studied tree species represent less than $1 \%$ of the c. 800 tree species abundant in the study area. For a better understanding of nitrogen uptake and preferences for different nitrogen forms, tracer studies with more species at different elevations should be conducted, especially for getting a clearer picture of the uptake capabilities of organic nitrogen by $\mathrm{AM}$ tree species in tropical montane forests. Furthermore, variation in natural abundance foliar $\Delta \delta^{15} \mathrm{~N}$-values along elevational gradients could help investigating the use of different nitrogen forms at the stand level even if some uncertainties of interpretation exist (e.g. Averill and Finzi, 2011 in temperate forests). Apart from studying nitrogen uptake in more tree species, one could additionally investigate the different forms of nitrogen in detail. Glycine, the amino acid we used in this study, is frequently used in studies on the uptake of soluble organic nitrogen by plants because it is small and charged neutral and, hence, taken up easily. However, glycine is only one of many organic nitrogen compounds that might be taken up by trees. Analysing additionally bigger amino acids charged negatively or positively, could help getting more accurate results on organic nitrogen uptake. It should be taken into account for future ${ }^{15} \mathrm{~N}$ tracer studies in tropical montane forests, with 2 to 8 days between application and harvest, that it is necessary to use double-labelled instead of single-labelled glycine. In our experiment, the calculation of uptake rates from ${ }^{15} \mathrm{~N}$ single-labelled glycine would have led to a more than 10-fold overestimation for some species. Dicyandiamide, the nitrification inhibitor we used in the ammonium treatment, worked well at 2000 and $3000 \mathrm{~m}$ elevation but came to its limits after 5 days at $1000 \mathrm{~m}$ elevation. 


\section{Suggestions for future research}

As part of the Tropical Andes, the Andean forests of Ecuador belong to one of the world's hotspots of biodiversity (Myers et al., 2000). Brummitt and Lughadha (2003) even described the Tropical Andes as the "hottest hotspot" worldwide. In this thesis, we studied 6 tree species in a ${ }^{15} \mathrm{~N}$ tracer study and forty tree species in a gas exchange study in South Ecuador, representing only less than $5 \%$ of the c. 800 tree species in the study area. Globally, approximately 37000 woody taxa exist in the tropics (Odegaard, 2000). Consequently, more species should be studied in the future. Pooling the abundant species of one site instead of replicating the same species at a site is one possibility of including more species in a study and getting more representative results.

We measured the photosynthesis of sun-leaves of mature trees of representative species along the altitudinal gradient. To be more accurate in calculating canopy carbon gain, in a next step, light response curves of shade leaves and at various temperatures should be measured. It would be good, to get better access to the suncanopy of the trees to be able to choose the abundant species without restrictions because of poor accessibility from the ground. Better access and bigger species numbers could make it possible to distinguish the photosynthetic capacity of different tree functional groups.

One outcome of the ${ }^{15} \mathrm{~N}$ tracer study that we conducted at three different elevations was the importance of the use of a nitrification inhibitor (DCD for maximum 5 days) when studying the uptake of ammonium and the use of a double-labelled amino acid when studying the uptake of organic nitrogen. Apart from examining more species, the analysis of foliar $\delta^{15} \mathrm{~N}$ values could be a possibility to extend our knowledge of the acquisition of different nitrogen forms to the stand level. However, the interpretation of the foliar $\delta^{15} \mathrm{~N}$ values is often complicated. The best approach seems to be a combination of tracer study paying special attention to the mycorrhiza and the analysis of foliar $\delta^{15} \mathrm{~N}$ values (e.g. Averill and Finzi, 2011). 


\section{References}

Amundson, R., 2003. Global patterns of the isotopic composition of soil and plant nitrogen. Global Biogeochemical Cycles 17.

Angert, A.L., 2006. Growth and leaf physiology of monkeyflowers with different altitude ranges. Oecologia 148, 183-194.

Arndt, S.K., Wanek, W., Hoch, G., Richter, A., Popp, M., 2002. Flexibility of nitrogen metabolism in the tropical C3-crassulacean acid metabolism tree species Clusia minor. Functional Plant Biology 29, 741-747.

Averill, C., Finzi, A., 2011. Increasing plant use of organic nitrogen with elevation is reflected in nitrogen uptake rates and ecosystem $\delta 15 N$. Ecology 92, 883-891.

Brummitt, N., Lughadha, E.N., 2003. Biodiversity: where's hot and where's not. Conservation Biology 17, 1442-1448.

Chalot, M., Brun, A., 1998. Physiology of organic nitrogen acquisition by ectomycorrhizal fungi and ectomycorrhizas. FEMS Microbiology Reviews 22, 21-44.

Cordell, S., Goldstein, G., Meinzer, F.C., Handley, L.L., 1999. Allocation of nitrogen and carbon in leaves of Metrosideros polymorpha regulates carboxylation capacity and delta ${ }^{13} \mathrm{C}$ along an altitudinal gradient. Functional Ecology 13, 811-818.

Craine, J.M., Elmore, A.J., Aidar, M.P.M., Bustamante, M., Dawson, T.E., Hobbie, E.A., Kahmen, A., Mack, M.C., McLauchlan, K.K., Michelsen, A., Nardoto, G.B., Pardo, L.H., Peñuelas, J., Reich, P.B., Schuur, E.A.G., Stock, W.D., Templer, P.H., Virginia, R.A., Welker, J.M., Wright, I.J., 2009. Global patterns of foliar nitrogen isotopes and their relationships with climate, mycorrhizal fungi, foliar nutrient concentrations, and nitrogen availability. New Phytologist 183, 980-992.

Evans, J.R., 1989. Photosynthesis and nitrogen relationships in leaves of C 3 plants. Oecologia 78, 9-19.

Goller, R., Wilcke, W., Fleischbein, K., Valarezo, C., Zech, W., 2006. Dissolved nitrogen, phosphorus, and sulfur forms in the ecosystem fluxes of a montane forest in Ecuador. Biogeochemistry 77, 57-89.

Homeier, J., Hertel, D., Camenzind, T., Cumbicus, N.L., Maraun, M., Martinson, G.O., Poma, N., Rillig, M.C., Sandmann, D., Scheu, S., Veldkamp, E., Wilke, W., Wullaert, H., Leuschner, C., 2012. Tropical andean forests are highly susceptible to Nutrient Inputs-rapid effects of experimental $\mathrm{N}$ and $\mathrm{P}$ addition to an ecuadorian montane forest. PLoS ONE 7, e47128.

Körner, C., 2007. The use of "altitude" in ecological research. Trends in Ecology \& Evolution 22, 569-574. 
Kottke, I., Beck, A., Oberwinkler, F., Homeier, J., Neill, D., 2004. Arbuscular endomycorrhizas are dominant in the organic soil of a neotropical montane cloud forest. Journal of Tropical Ecology 20, 125-129.

Letts, M.G., Mulligan, M., Rincon-Romero, M.E., Bruijnzeel, L.A., 2011. Environmental controls on photosynthetic rates of lower montane cloud forest vegetation in south-western Colombia, in: Tropical Montane Cloud Forests, International Hydrology Series. Cambridge University Press.

Leuschner, C., Zach, A., Homeier, J., Graefe, S., Hertel, D., Wittich, B., Soethe, N., lost, S., Röderstein, M., Horna, V., Wolf, K., 2013. The carbon balance of tropical mountain forests along an altitudinal transect. Ecological Studies.

Moser, G., Hertel, D., Leuschner, C., 2007. Altitudinal change in LAl and stand leaf biomass in tropical montane forests: a transect study in Ecuador and a pantropical meta-analysis. Ecosystems 10, 924-935.

Moser, G., Leuschner, C., Hertel, D., Graefe, S., Soethe, N. \& lost, S. 2011. Elevation effects on the carbon budget of tropical mountain forests (S Ecuador): the role of the belowground compartment. Global Change Biology 17, 2211-2226.

Myers, N., Mittermeier, R.A., Mittermeier, C.G., Da Fonseca, G.A.., Kent, J., 2000. Biodiversity hotspots for conservation priorities. Nature 403, 853-858.

Odegaard, F., 2000. How many species of arthropods? Erwin's estimate revised. Biological Journal of the Linnean Society 71, 583-597.

Paoli, G.D., Curran, L.M., Zak, D.R., 2005. Phosphorus efficiency of Bornean rain forest productivity: Evidence against the unimodal efficiency hypothesis. Ecology 86, 1548-1561.

Reich, P.B., Ellsworth, D.S., Walters, M.B., Vose, J.M., Gresham, C., Volin, J.C., Bowman, W.D., 1999. Generality of leaf trait relationships: a test across six biomes. Ecology 80, 1955-1969.

Santiago, L.S., Goldstein, G., Meinzer, F.C., Fisher, J.B., Machado, K., Woodruff, D., Jones, T., 2004. Leaf photosynthetic traits scale with hydraulic conductivity and wood density in Panamanian forest canopy trees. Oecologia 140, 543550.

Santiago, L.S., Wright, S.J., 2007. Leaf functional traits of tropical forest plants in relation to growth form. Functional Ecology 21, 19-27.

Tanner, E.V.J., Vitousek, P.M., Cuevas, E., 1998. Experimental investigation of nutrient limitation of forest growth on wet tropical mountains. Ecology 79, 1022.

Van de Weg, M.J., Meir, P., Grace, J., Atkin, O.K., 2009. Altitudinal variation in leaf mass per unit area, leaf tissue density and foliar nitrogen and phosphorus content along an Amazon-Andes gradient in Peru. Plant Ecology \& Diversity 2, 
243-254.

Wanek, W., Arndt, S.K., Huber, W., Popp, M., 2002. Nitrogen nutrition during ontogeny of hemiepiphytic Clusia species. Functional Plant Biology 29, $733-$ 740.

Warren, C.R., 2011. Post- uptake metabolism affects quantification of amino acid uptake. New Phytologist 193, 522-531.

Wolf, K., Veldkamp, E., Homeier, J., Martinson, G.O., 2011. Nitrogen availability links forest productivity, soil nitrous oxide and nitric oxide fluxes of a tropical montane forest in southern Ecuador. Global Biogeochemical Cycles 25.

Zach, A., Horna, V., Leuschner, C., 2008. Elevational change in woody tissue CO2 efflux in a tropical mountain rain forest in southern Ecuador. Tree physiology 28, 67-74. 


\section{CHAPTER 6}

Summary / Zusammenfassung 


\section{Summary}

With increasing elevation, the growth conditions of trees in tropical mountains become generally more adverse in terms of decreasing nutrient availabilities, decreasing temperatures and decreasing atmospheric concentration of carbon dioxide $\left(\mathrm{CO}_{2}\right)$. In tropical montane forests, reduced decomposition rates at higher altitudes lead to thicker organic layers and together with reduced mineralization and nitrification rates to a change in available nitrogen forms and nitrogen has been shown to limit productivity in these forests. How photosynthetic capacity $\left(A_{\max }\right)$ of tropical trees on the one hand, and nitrogen uptake capacity and nitrogen form preference on the other hand adapt to variation in environmental conditions along elevation gradients, is not precisely known.

The present study was conducted in three tropical montane forest stands along an elevational transect at 1000, 2000 and $3000 \mathrm{~m}$ asl in South Ecuador. It aimed (1) to quantify the photosynthetic capacity of adult tropical trees along the elevational transect by means of gas exchange measurements and to analyse the possible controlling effects of temperature, partial pressure of $\mathrm{CO}_{2}$ and nutrient availability on photosynthesis and (2) to investigate altitudinal changes in the use of nitrate, ammonium and organic nitrogen sources by tropical forest trees by means of a stable isotope tracer study with seedlings.

Stand-level means of light-saturated net photosynthesis $\left(A_{\text {sat }}\right)$ were 8.8, 11.3 and 7.2 $\mu \mathrm{mol} \mathrm{CO}_{2} \mathrm{~m}^{-2} \mathrm{~s}^{-1}$; those of dark respiration $\left(\mathrm{R}_{\mathrm{D}}\right)$ 0.8, 0.6 and $0.7 \mu \mathrm{mol} \mathrm{CO}_{2} \mathrm{~m}^{-2} \mathrm{~s}^{-1}$ at 1000, 2000 and $3000 \mathrm{~m}$ elevation, respectively, with no significant altitudinal trend. Examining our data in the context of a pan-tropical $A_{\text {sat }}$ data base for mature tropical trees (c. 170 species from 18 sites at variable elevation) revealed that area-based $\mathrm{A}_{\text {sat }}$ decreases in tropical mountains by, on average, $1.3 \mu \mathrm{mol} \mathrm{CO}_{2} \mathrm{~m}^{-2} \mathrm{~s}^{-1}$ per $\mathrm{km}$ altitude increase (or by $0.2 \mu \mathrm{mol} \mathrm{CO}_{2} \mathrm{~m}^{-2} \mathrm{~s}^{-1}$ per $\mathrm{K}$ temperature decrease). The $A_{\text {sat }}$ decrease occurred despite an increase in leaf mass per area with altitude. Lowered $A_{\text {sat }}$ together with a reduced stand leaf area decrease canopy carbon gain with elevation in tropical mountains. 
The $P$ content per leaf mass was the principal factor determining $A_{\max }$ across the altitudinal gradient while the effects of foliar $\mathrm{N}$, temperature and $\left[\mathrm{CO}_{2}\right]$ were insignificant. $A_{\max }$ was subject to partial, and $R_{D}$ to full homeostatic adjustment to the reductions in temperature and $\left[\mathrm{CO}_{2}\right]$ at higher elevations, mainly through a large reduction in SLA and the resulting increase in foliar $N$ and $P$ per leaf area, while no altitudinal increase in carboxylation efficiency was detected. We conclude that the altitudinal decrease in both SLA and canopy leaf area are more important determinants of carbon gain in tropical high-elevation forests than adaptive physiological modifications in the photosynthetic apparatus.

The seedlings of six tree species differed with respect to their nitrogen form preference but neither the abundance of ammonium and nitrate in the soil nor altitude seemed to influence the preference. Two species (those with highest growth rate) preferred ammonium over nitrate while the other four species took up nitrate and ammonium at similar rates when both nitrogen forms were equally available. After ${ }^{15} \mathrm{~N}^{13} \mathrm{C}$-glycine addition, ${ }^{13} \mathrm{C}$ was significantly accumulated in the biomass of three species (two species with arbuscular and one species with ectomycorrhizal symbionts) in addition to a siginficant ${ }^{15} \mathrm{~N}$ accumulation indicating that trees in tropical mountain forests can use organic nitrogen sources irrespective of the type of their mycorrhiza. 


\section{Zusammenfassung}

Mit zunehmender Meereshöhe werden die Wachstumsbedingungen in tropischen Bergregionen im Allgemeinen ungünstiger, was sich in einer sinkenden Nährstoffverfügbarkeit, sinkenden Temperaturen und sinkendem $\mathrm{CO}_{2}$-Partialdruck zeigt. In tropischen Bergregenwäldern führen verminderte Abbauraten in größeren Höhen einerseits zu dicken organische Auflageschichten und andererseits in Kombination mit verminderten Mineralisierungs- und Nitrifizierungsraten zu Veränderungen in der Verfügbarkeit der verschiedenen Stickstoffformen, und es gibt Nachweise einer Limitierung der Produktivität dieser Wälder durch Stickstoff. Auf welche Weise sich die Photosynthesekapazität $\left(A_{\max }\right)$ tropischer Bäume einerseits und die Stickstoffaufnahmekapazität und Präferenz für einzelne Stickstoffformen andererseits an die veränderten Umweltbedingungen entlang von Höhengradienten adaptieren ist nicht genau bekannt.

Die vorliegende Untersuchung wurde in drei tropischen Bergregenwäldern durchgeführt, die entlang eines Höhengradienten auf 1000, 2000 und 3000 m ü. NN in Südequador liegen. Das Ziel war es, (1) die Photosynthesekapazität ausgewachsener tropischer Bäume entlang eines Höhengradienten mit Hilfe von Gaswechselmessungen zu bestimmen und die Effekte von Temperatur, $\mathrm{CO}_{2^{-}}$ Partialdruck und Nährstoffverfügbarkeit auf die Photosynthese zu quantifizieren und (2) Veränderungen in der Verwendung von Nitrat, Ammonium und organischen Stickstoffquellen durch tropische Waldbäume mit der Meereshöhe mittels einer Tracer-Untersuchung mit stabilen Isotopen an Jungpflanzen zu untersuchen.

Mittelwerte der lichtgesättigten Photosyntheserate $\left(A_{\text {sat }}\right)$ auf Bestandeseben betrugen 8.8, 11.3 und $7.2 \mu \mathrm{mol} \mathrm{CO}_{2} \mathrm{~m}^{-2} \mathrm{~s}^{-1}$, die der Dunkelatmung $\left(\mathrm{R}_{\mathrm{D}}\right)$ 0.8, 0.6 und $0.7 \mu \mathrm{mol}$ $\mathrm{CO}_{2} \mathrm{~m}^{-2} \mathrm{~s}^{-1}$ jeweils auf 1000, 2000 and $3000 \mathrm{~m}$ Meereshöhe, ohne einen signifikanten Höhentrend. Die Einordnung unserer Daten in den Kontext eines pantropischen $A_{\text {sat }}$-Datensatzes von tropischen Bäumen (c. 170 Arten an 18 Standorten unterschiedlicher Meereshöhe) zeigte, dass das flächenbezogene $A_{\text {sat }}$ in tropischen Bergen im Mittel $1.3 \mu \mathrm{mol} \mathrm{CO}_{2} \mathrm{~m}^{-2} \mathrm{~s}^{-1}$ pro $\mathrm{km}$ Höhenzunahme abnimmt 
(bzw. $0.2 \mu \mathrm{mol} \mathrm{CO}_{2} \mathrm{~m}^{-2} \mathrm{~s}^{-1}$ pro $\mathrm{K}$ Temperaturabnahme). Die Abnahme von $\mathrm{A}_{\mathrm{sat}}$ trat auf, obwohl die Blattmasse je Fläche mit der Höhe zunahm. Eine verminderte Photosyntheserate und eine reduzierte Bestandesblattfläche bewirken gemeinsam eine Verringerung der Kohlenstoffaufnahme des Kronenraums mit der Meereshöhe in tropischen Bergregionen.

Der Phosphorgehalt pro Blattmasse war der Faktor, der $A_{\max }$ entlang des Höhengradienten hauptsächlich beeinflusste, während die Effekte von Blattstickstoff, Temperatur und $\mathrm{CO}_{2}$-Partialdruck nicht signifikant waren. $\mathrm{A}_{\max }$ erfuhr einen teilweisen und $R_{D}$ einen vollständigen homöostatischen Ausgleich als Reaktion auf die Verminderung von Temperatur und $\mathrm{CO}_{2}$-Partialdruck in größeren Höhen, was hauptsächlich durch eine stark reduzierte spezifische Blattfläche (SLA) und die daraus entstehende Zunahme von Blattstickstoff und -phosphor je Blattfläche bedingt war, während keine Zunahme der Karboxylierungseffizienz festgestellt wurde. Wir schlussfolgern, dass die Verminderung von SLA und Gesamtblattfläche mit der Meereshöhe die Kohlenstoffaufnahme von tropischen Wäldern in großen Meereshöhen deutlich stärker bestimmen als adaptive physiologische Modifizierungen des Photsyntheseapparates.

Jungpflanzen von sechs Baumarten unterschieden sich hinsichtlich ihrer Präferenz für verschieden Stickstoffformen, allerdings schienen weder das Amonium- und Nitratvorkommen im Boden noch die Meereshöhe die Präferenz zu beeinflussen. Zwei Arten (jeweils die, mit den höchsten Wachstumsraten) bevorzugten Amonium gegenüber Nitrat, während die restlichen vier Arten Nitrat und Amonium mit ähnlichen Raten aufnahmen, wenn beide Stickstofformen verfügbar waren. Nach der Gabe von ${ }^{15} \mathrm{~N}^{13} \mathrm{C}$-Glyzin zeigte sich bei drei Arten eine signifikante Akkumulierung von ${ }^{13} \mathrm{C}$ in der Biomasse (zwei Arten mit arbuskulären Mykorrhiza und eine Art mit Ektomykorrhiza) zusätzlich zu einer signifikanten Akkumulierung von ${ }^{15} \mathrm{~N}$, was darauf hindeutet, dass Bäume in tropischen Bergregenwäldern organische Stickstoffverbindungen unabhängig vom Typ ihrer Mykorrhizierung aufnehmen können. 
CHAPTER 7

\author{
Appendix
}




\section{Supplementary material of Chapter 2}

Table 5. Light-saturated net photosynthesis at ambient temperature and $\left[\mathrm{CO}_{2}\right]\left(\mathrm{A}_{\mathrm{sat}}\right)$, foliar $\mathrm{N}$ and $P$ concentrations $\left(\mathrm{N}_{\mathrm{m}}, \mathrm{P}_{\mathrm{m}}\right)$ and leaf mass per area (LMA) of ca. 169 tree species (or morphotypes) of lowland to upper montane tropical forests according to various authors. For $A_{\text {sat }}$, area- or massbased species means $( \pm \mathrm{SE}$ ) are given. Only measurements referring to mature or pre-mature tree individuals (no seedlings and saplings) of nonpioneer stands were considered. $A_{s a t}$ values obtained at irradiances $<1200 \mu \mathrm{mol}$ photons $\mathrm{m}^{-2} \mathrm{~s}^{-1}$ were only included if that flux density was explicitly identified as being saturating. If information was available, $T$ and PPFD refer to the temperature and irradiance conditions during the measurements; otherwise, MAT is given. only data referring to sun-lit, fully expanded leaves of the upper canopy were included. Wet season data were preferred over dry season data if both were given. The sequence of locations mainly follows the altitudinal gradient. For comparison in the leaf chemical analyses, $\mathrm{N}_{\mathrm{m}}, \mathrm{P}_{\mathrm{m}}$ and LMA data of additional 35 species from a transect in Peru are included in the list, even though $\mathrm{A}_{\text {sat }}$ data are not available.

\begin{tabular}{|c|c|c|c|c|c|c|c|c|c|c|c|}
\hline Location & $\begin{array}{c}\text { Eleva- } \\
\text { tion } \\
\text { m a.s.I } \\
.\end{array}$ & $\begin{array}{l}\text { Tem- } \\
\text { pera- } \\
\text { ture } \\
{ }^{\circ} \mathrm{C}\end{array}$ & $m m y r^{-1}$ & Species & $\begin{array}{c}\mathbf{A}_{\text {sat }} \\
\mu m o l \\
m^{-2} s^{-1}\end{array}$ & SE & $\begin{array}{c}n m o l g \\
{ }^{1} s^{-1}\end{array}$ & $m g g^{-1}$ & $m g g^{-1}$ & $g m^{-<}$ & $\begin{array}{l}\text { Refe- } \\
\text { rence }\end{array}$ \\
\hline \multicolumn{12}{|l|}{ Lowland } \\
\hline \multirow[t]{4}{*}{ Venezuela } & 100 & 26 & 3565 & Cecropia ficifolia & 17.7 & -- & 252.2 & 24.7 & -- & 69.16 & (1) \\
\hline & 100 & 26 & 3565 & Vismia lauriformis & 13.8 & -- & 159.3 & 17.9 & -- & 87.49 & \\
\hline & 100 & 26 & 3565 & Clidemia sericea & 9.1 & -- & 115.5 & 16.5 & -- & 79.11 & \\
\hline & 100 & 26 & 3565 & Vismia japurensis & 12.8 & -- & 140.4 & 16.4 & -- & 94.88 & \\
\hline
\end{tabular}




\begin{tabular}{|c|c|c|c|}
\hline 100 & 26 & 3565 & Belinda grossularioides \\
\hline 100 & 26 & 3565 & Goupia glabra \\
\hline 100 & 26 & 3565 & Neea obovata \\
\hline 100 & 26 & 3565 & Miconia dispar \\
\hline 100 & 26 & 3565 & Retiniphyllum truncalum \\
\hline 100 & 26 & 3565 & Rhodognaphalopsis humilis \\
\hline 100 & 26 & 3565 & Protium sp. \\
\hline 100 & 26 & 3565 & Aspidosperma album \\
\hline 100 & 26 & 3565 & Protium sp. \\
\hline 100 & 26 & 3565 & Caraipa heterocarpa \\
\hline 100 & 26 & 3565 & Ocotea costulata \\
\hline 100 & 26 & 3565 & Licania heteromorpha \\
\hline 100 & 26 & 3565 & Eperua purpurea \\
\hline 100 & 26 & 3565 & E. leucantha \\
\hline 100 & 26 & 3565 & Leguminosae sp. \\
\hline 100 & 26 & 3565 & Micrandra sprucei \\
\hline
\end{tabular}

\begin{tabular}{|c|c|c|c|c|c|}
\hline 14.0 & -- & 111.5 & 16.9 & -- & 128.04 \\
\hline 7.8 & -- & 99.0 & 15.1 & -- & 76.98 \\
\hline 6.4 & -- & 65.0 & 18.4 & -- & 96.99 \\
\hline 10.3 & -- & 91.8 & 15.9 & -- & 110.74 \\
\hline 5.6 & -- & 46.5 & 6.8 & -- & 120.77 \\
\hline 6.2 & -- & 47.2 & 7.8 & -- & 132.98 \\
\hline 4.0 & -- & 34.7 & 8.6 & -- & 115.47 \\
\hline 6.5 & -- & 52.2 & 10.7 & -- & 121.07 \\
\hline 8.2 & -- & 67.2 & 17.7 & -- & 121.95 \\
\hline 5.7 & -- & 38.8 & 9.3 & -- & 147.49 \\
\hline 5.9 & -- & 44.9 & 15.0 & -- & 130.21 \\
\hline 8.0 & -- & 53.8 & 13.0 & -- & 148.59 \\
\hline & -- & 55.1 & 15.2 & -- & \\
\hline 3.7 & -- & 35.1 & 12.5 & -- & 105.15 \\
\hline 6.7 & -- & 47.7 & 21.4 & -- & 138.69 \\
\hline 7.4 & -- & 43.3 & 10.8 & -- & 171.23 \\
\hline
\end{tabular}


$100 \quad 26 \quad 3565$ Micropholis maguirei

100 26 3565 Protium sp

Panama

$\begin{array}{llll}130 & 31 & 3100 & \text { Vochysia ferruginea } \\ 130 & 31 & 3100 & \text { Simarouba amara } \\ 130 & 31 & 3100 & \text { Miconia borealis } \\ 130 & 31 & 3100 & \text { Pourouma bicolor } \\ 130 & 31 & 3100 & \text { Virola sebifera } \\ 130 & 31 & 3100 & \text { Tapirira guianensis } \\ 130 & 31 & 3100 & \text { Ocotea ira } \\ 130 & 31 & 3100 & \text { Dussia munda } \\ 130 & 31 & 3100 & \text { Guatteria dumentorum } \\ 130 & 31 & 3100 & \text { Trattinickia aspera } \\ 130 & 31 & 3100 & \text { Poulsenia armata } \\ 130 & 31 & 3100 & \text { Humiriastrum diguense } \\ 130 & 3100 & \text { Nectandra purpurascens }\end{array}$

$\begin{array}{rrrrr}--- & -- & 8.0 & -- & 180.83 \\ 5.7-- & 33.0 & 10.3 & -- & 172.12\end{array}$

$\begin{array}{lllllll}18.3 & - & -- & -- & -- & -- & (2)\end{array}$

17.5

16.8

13.7

13.5

12.9

12.6

12.3

12.2

12.2

11.8

11.2

11.1 


$\begin{array}{llll}130 & 31 & 3100 & \text { Manilkara bidentata } \\ 130 & 31 & 3100 & \text { Marila laxiflora } \\ 130 & 31 & 3100 & \text { Aspidosperma cruenta } \\ 130 & 31 & 3100 & \text { Apeiba membranacea } \\ 130 & 31 & 3100 & \text { Simarouba amara } \\ 130 & 31 & 3100 & \text { Vochysia ferruginea } \\ 130 & 31 & 3100 & \text { Jacaranda copaia } \\ 130 & 31 & 3100 & \text { Aspidosperma cruenta } \\ 130 & 31 & 3100 & \text { Manilkara bidentata } \\ 130 & 31 & 3100 & \text { Brosimum utile }\end{array}$

$\begin{array}{rrrrr}10.3-- & -- & -- & -- & -- \\ 9.9-- & -- & -- & -- & -- \\ 9.7-- & -- & -- & -- & -- \\ 16.1-- & -- & -- & -- & -- \\ 15.7-- & -- & -- & -- & -- \\ 15.2-- & -- & -- & -- & -- \\ 14.6-- & -- & -- & -- & -- \\ 14.2-- & -- & -- & -- & -- \\ 11.8-- & -- & -- & -- & - \\ 10.4-- & -- & -- & -- & -\end{array}$

$\begin{array}{llll}\text { Panama } & 140 & 26 & 3100 \text { Apeiba membranaceae } \\ 140 & 26 & 3100 \text { Aspidosperma cruentum } \\ 140 & 26 & 3100 \text { Brosimum utile } \\ 140 & 26 & 3100 \text { Calophyllum longifolium } \\ 140 & 26 & 3100 \text { Carapa guianensis }\end{array}$

$\begin{array}{llllll}14.9-- & 133.3 & 25.8 & 1.12 & 111.86 & (3) \\ 10.2-- & 65.9 & 20.4 & 0.84 & 155.04 \\ 11.4-- & 77.6 & 18.3 & 1.04 & 146.20 \\ 11.2-- & 43.4 & 12.1 & 0.72 & 258.40 \\ 10.1-- & 49.3 & 13.7 & 0.86 & 205.34\end{array}$




$\begin{array}{llll}140 & 26 & 3100 & \text { Cecropia insignis } \\ 140 & 26 & 3100 & \text { C. obtusifolia } \\ 140 & 26 & 3100 & \text { Dussia munda } \\ 140 & 26 & 3100 & \text { Jacaranda copaia } \\ 140 & 26 & 3100 & \text { Lonchocarpus latifolius } \\ 140 & 26 & 3100 & \text { Manilkara bidentata } \\ 140 & 26 & 3100 & \text { Miconia borealis } \\ 140 & 26 & 3100 & \text { Nectandra purpurea } \\ 140 & 26 & 3100 & \text { Ochroma pyrmidale } \\ 140 & 26 & 3100 & \text { Oenocarpus mapora } \\ 140 & 26 & 3100 & \text { Pourouma bicolor } \\ 140 & 26 & 3100 & \text { Simarouba amara } \\ 140 & 26 & 3100 & \text { Socratea exorrhiza } \\ 140 & 26 & 3100 & \text { Tapirira guianensis } \\ 140 & 26 & 3100 & \text { Trema micrantha } \\ 140 & 26 & 3100 & \text { Vochysia ferruginea }\end{array}$

$\begin{array}{rrrrr}15.7-- & 143.1 & 17.1 & 1.24 & 110.01 \\ 13.2-- & 350.8 & 41.6 & 3.04 & 37.48 \\ 11.9-- & 105.8 & 21.1 & 1.14 & 112.11 \\ 16.3-- & 157.8 & 25.5 & 1.21 & 103.52 \\ 14.8-- & 102.9 & 18.4 & 1.06 & 144.09 \\ 13.4-- & 78.0 & 16.5 & 0.83 & 172.12 \\ 15.3-- & 158.3 & 22.0 & 1.30 & 96.34 \\ 10.9-- & 73.6 & 17.8 & 0.77 & 147.71 \\ 14.5-- & 224.7 & 21.4 & 1.49 & 64.68 \\ 7.6-- & 67.9 & 20.5 & 1.27 & 112.23 \\ 15.8-- & 110.5 & 20.0 & 1.24 & 142.65 \\ 13.8-- & 78.6 & 17.4 & 0.65 & 176.06 \\ 11.2-- & 76.7 & 19.9 & 1.24 & 146.20 \\ 13.0-- & 92.2 & 15.4 & 0.88 & 141.24 \\ 13.4-- & 169.7 & 20.9 & 0.87 & 78.93 \\ 15.9-- & 138.7 & 17.3 & 1.00 & 114.29\end{array}$




$\begin{array}{lllll}\text { Malaysia } & 150 & 28 & 3150 \text { Macaranga hypoleuca } \\ \text { (Sabah) } & 150 & 28 & 3150 \text { Dinochloa trichogona } \\ & 150 & 28 & 3150 \text { Chisocheton macranthus } \\ 150 & 28 & 3150 \text { Glochidion rubrum } \\ 150 & 28 & 3150 \text { Dryobalanops lanceolata } \\ & 150 & 28 & 3150 \text { Acacia mangium } \\ 150 & 28 & 3150 \text { Parashorea tomentella } \\ 150 & 28 & 3150 \text { Shorea seminis } \\ 150 & 28 & 3150 \text { S. xanthophylla } \\ 150 & 28 & 3150 \text { Pentace adenophora } \\ 150 & 28 & 3150 \text { Dipterocarpus caudiferus }\end{array}$

$\begin{array}{lll}14.2 & -- & -- \\ 11.6 & -- & -- \\ 9.5 & -- & -- \\ 8.8 & -- & -- \\ 7.3 & -- & -- \\ 6.3 & -- & -- \\ 6.1 & -- & -- \\ 6.0 & -- & -- \\ 5.9 & -- & -- \\ 5.6 & -- & -- \\ 5.0 & -- & --\end{array}$

Malaysia

20030 2100-3300 Shorea beccariana

(Sarawak)

$200 \quad 30 \quad 2100-3300$ S. acuta

$20030 \quad 2100-3300$ Dryobalanops aromatica

$\begin{array}{ccccc}17.9-- & -- & -- & -- & - \\ 10.7-- & -- & -- & -- & -- \\ 10.2-- & -- & -- & -- & --\end{array}$


$200302100-3300$ Dipterocarpus globosus

$20030 \quad 2100-3300$ Shorea macroptera

Peru

$220 \quad 26.4 \quad 2730$ Pourouma cecropiifolia

$200 \quad 26.4 \quad 2730$ Rinorea viridifolia

$220 \quad 26.4 \quad 2730$ Symphonia globulifera

$220 \quad 26.4 \quad 2730$ Iryanthera juruensis

$220 \quad 26.4 \quad 2730$ Bixa arborea

$22026.4 \quad 2730$ Brosimum guianense

$220 \quad 26.4 \quad 2730$ Micropholis guyanensis

$220 \quad 26.4 \quad 2730 \quad$ Neea divaricata.

$\begin{array}{llll}\text { S China } & 570 & 21.7 & 1560 \text { Anisoptera costata } \\ & 570 & 21.7 & 1560 \text { Dipterocarpus alatus }\end{array}$

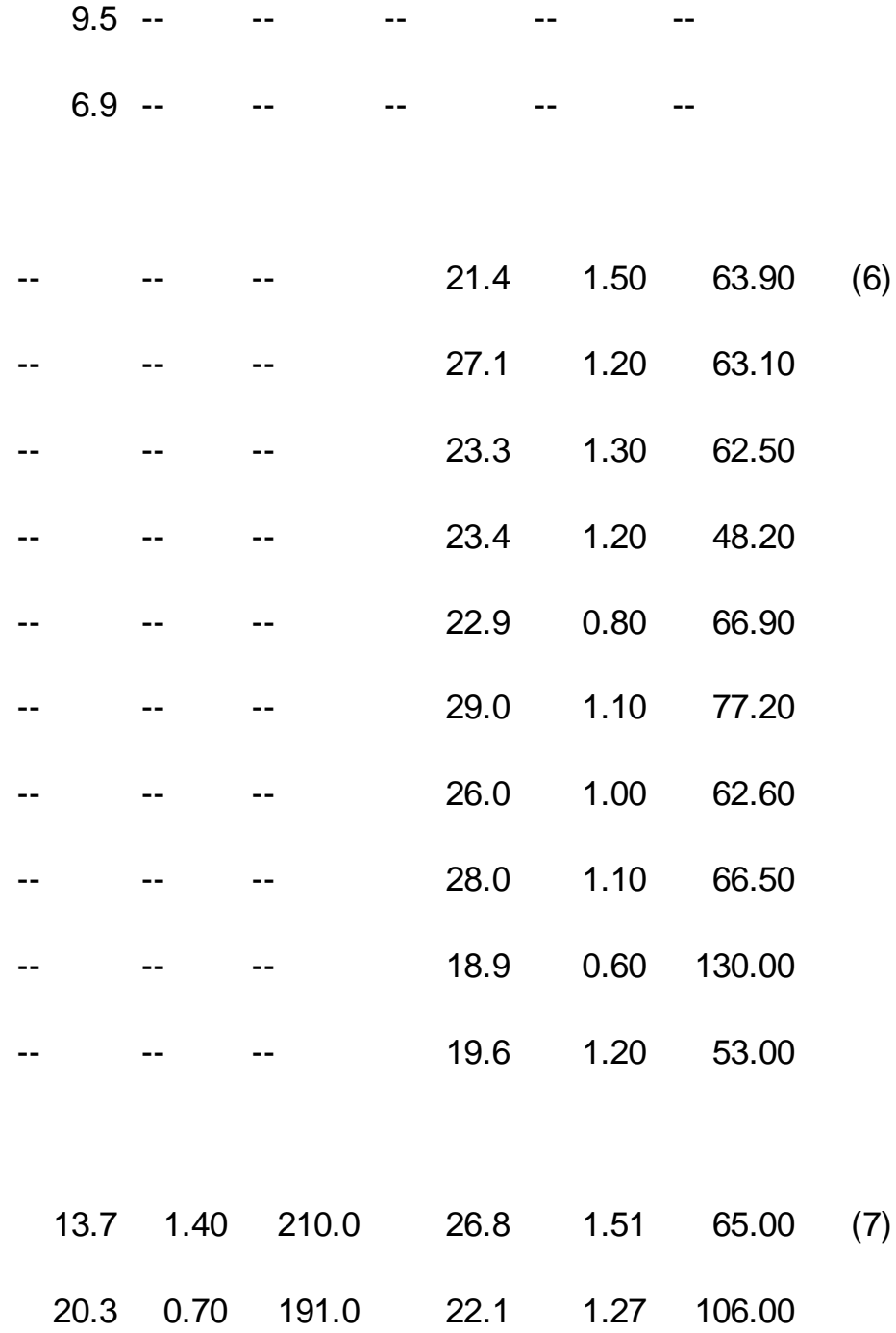




$\begin{array}{llll}570 & 21.7 & 1560 & \text { D. intricatus } \\ 570 & 21.7 & 1560 & \text { D. retusus } \\ 570 & 21.7 & 1560 & \text { D. tuberculatus } \\ 570 & 21.7 & 1560 & \text { D. turbinatus } \\ 570 & 21.7 & 1560 & \text { Hopea chinensis } \\ 570 & 21.7 & 1560 & \text { H. hainanensis } \\ 570 & 21.7 & 1560 & \text { H. hongayensis } \\ 570 & 21.7 & 1560 & \text { H. mollissima } \\ 570 & 21.7 & 1560 & \text { Parashorea chinensis } \\ 570 & 21.7 & 1560 & \text { Shorea assamica } \\ 570 & 21.7 & 1560 & \text { S. robusta } \\ 570 & 21.7 & 1560 & \text { Shorea sp. } \\ 570 & 21.7 & 1560 & \text { Vatica guangxiensis } \\ 570 & 21.7 & 1560 & \text { V. mangachapoi } \\ 570 & 21.7 & 1560 & \text { V. xishuangbannaensis }\end{array}$

\begin{tabular}{rrrrrr}
14.7 & 1.40 & 105.0 & 16.2 & 1.08 & 152.00 \\
14.0 & 0.70 & 132.0 & 19.4 & 1.40 & 106.00 \\
18.9 & 0.70 & 177.0 & 18.5 & 1.12 & 107.00 \\
16.1 & 0.70 & 158.0 & 19.0 & 1.17 & 101.00 \\
9.9 & 0.80 & 124.0 & 22.0 & 1.21 & 80.00 \\
10.1 & 0.60 & 102.0 & 20.0 & 1.38 & 98.00 \\
6.1 & 0.40 & 118.0 & 19.8 & 1.32 & 52.00 \\
7.2 & 0.20 & 82.0 & 19.6 & 1.33 & 88.00 \\
8.3 & 0.50 & 159.0 & 21.7 & 1.66 & 52.00 \\
10.7 & 0.60 & 165.0 & 19.3 & 1.17 & 65.00 \\
17.2 & 1.00 & 184.0 & 19.2 & 1.19 & 94.00 \\
9.7 & 0.60 & 89.0 & 18.9 & 0.99 & 112.00 \\
5.1 & 0.30 & 64.0 & 17.0 & 0.86 & 81.00 \\
\hline 9.3 & 0.70 & 97.0 & 17.8 & 1.16 & 96.00 \\
7.3 & 0.40 & 89.0 & 18.6 & 1.01 & 82.00
\end{tabular}


(Sabah)

Cameroon

$\begin{array}{llll}640 & 23 & 1522 & \text { Amphimas pterocarpoides } \\ 640 & 23 & 1522 & \text { Celtis adolfi-friderici } \\ 640 & 23 & 1522 & \text { Musanga cecropioides } \\ 640 & 23 & 1522 & \text { Staudtia stipitata } \\ 640 & 23 & 1522 & \text { Trichilia sp }\end{array}$

$\begin{array}{lllll}11.0-- & -- & 23.8 & 0.90 & 83.33 \\ 10.3-- & -- & 26.3 & 1.02 & 60.98 \\ 13.9-- & -- & 24.0 & 0.98 & 76.34 \\ 6.8-- & -- & 18.0 & 0.97 & 65.36 \\ 6.3-- & -- & 30.7 & 0.90 & 49.50\end{array}$

\section{Pre-montane/montane}

$\begin{array}{lllll}\text { Ecuador } & 1000 & 19 & 2230 & \text { Saurauia spec. } 1 \\ 1000 & 19 & 2230 & \text { Guatteria pastazae } \\ 1000 & 19 & 2230 \text { Hedyosmum sprucei } \\ 1000 & 19 & 2230 \text { Inga spec. } \\ 1000 & 19 & 2230 \text { Lozania klugii }\end{array}$

$\begin{array}{rrrrrrr}11.0 & 0.8 & 107.9 & 18.26 & 0.81 & 101.94 & (10) \\ 11.3 & 0.3 & 142.9 & 18.15 & 0.46 & 79.05 & \\ 12.0 & 0.5 & -- & 18.41 & 0.78 & -- & \\ 9.4 & 2.5 & 78.8 & 25.73 & 0.66 & 119.33 \\ 9.4 & 0.3 & 109.0 & 18.58 & 0.47 & 86.21\end{array}$




$\begin{array}{llll}1000 & 19 & 2230 & \text { Licaria cf terminalis } \\ 1000 & 19 & 2230 & \text { Mollia cf gracilis } \\ 1000 & 19 & 2230 & \text { Centronia laurifolia } \\ 1000 & 19 & 2230 & \text { Miconia spec. } \\ 1000 & 19 & 2230 & \text { Tibouchina ochipetala } \\ 1000 & 19 & 2230 & \text { Ficus cervantesiana } \\ 1000 & 19 & 2230 & \text { Ficus spec. } \\ 1000 & 19 & 2230 & \text { Neea cf divaricata } \\ 1000 & 19 & 2230 & \text { Cinchona spec. } \\ 1000 & 19 & 2230 & \text { Pouteria torta }\end{array}$

$\begin{array}{rrrrrr}6.1 & 1.0 & 65.1 & 26.21 & 0.48 & 93.72 \\ 5.4 & 0.4 & 92.8 & 20.80 & 0.65 & 58.21 \\ 7.9 & 0.7 & 57.3 & 10.34 & 0.25 & 137.93 \\ 6.9 & 0.5 & 41.9 & 14.10 & 0.37 & 164.47 \\ 16.0 & 1.0 & -- & 16.05 & 0.54 & - \\ 7.3 & 0.6 & 48.1 & 12.75 & 0.56 & 151.75 \\ 8.5 & 0.6 & -- & 11.06 & 0.49 & -- \\ 6.0 & 0.6 & 82.3 & 42.44 & 0.74 & 72.94 \\ 11.1 & 0.5 & 92.6 & 13.90 & 0.43 & 119.90 \\ 3.4 & 1.7 & 33.3 & 14.09 & 0.44 & 102.15\end{array}$

$\begin{array}{llll}\text { Indonesia } & 1100 & 20 & 1840 \text { Cananga odorata } \\ 1100 & 20 & 1840 \text { Bischofia javanica } \\ 1100 & 20 & 1840 \text { Semecarpus forstenii } \\ 1100 & 20 & 1840 \text { Aglaia argentea } \\ 1100 & 20 & 1840 \text { Litsea spec. }\end{array}$

\begin{tabular}{|c|c|c|c|c|}
\hline $13.2--$ & -- & -- & -- & -- \\
\hline 9.6 -- & -- & -- & -- & -- \\
\hline 9.1 -- & -- & -- & -- & -- \\
\hline 8.5 -- & -- & -- & -- & -- \\
\hline 5.4 & -- & -- & -- & -- \\
\hline
\end{tabular}




$\begin{array}{llll}1100 & 20 & 1840 & \text { Siphonodon celastrineus } \\ 1100 & 20 & 1840 & \text { Pimelodendron amboinicum } \\ 1100 & 20 & 1840 & \text { Meliosma sumatrana }\end{array}$

$\begin{array}{llll}\text { Ecuador } & 2000 & 16 & 1950 \text { Saurauia spec. } 2 \\ 2000 & 16 & 1950 \text { Piptocoma discolor } \\ 2000 & 16 & 1950 \text { Critoniopsis zamorensis } \\ 2000 & 16 & 1950 \text { Clethra revoluta } \\ 2000 & 16 & 1950 \text { Vismia cf tomentosa } \\ 2000 & 16 & 1950 \text { Aniba spec. } \\ 2000 & 16 & 1950 \text { Rhodostemonodaphne kunthiana } \\ 2000 & 16 & 1950 \text { Heliocarpus americanus } \\ 2000 & 16 & 1950 \text { Meriania hexamera } \\ 2000 & 16 & 1950 \text { Tibouchina lepidota } \\ 2000 & 16 & 1950 \text { Ficus pertusa } \\ 2000 & 16 & 1950 \text { F. citrifolia }\end{array}$

\begin{tabular}{|c|c|c|c|c|c|c|}
\hline 5.3 & & - & & & -- & \\
\hline 5.1 & & - & & & -- & \\
\hline 3.6 & & - & & & -- & \\
\hline 8.6 & 1.3 & 71.6 & 20.41 & 1.23 & 120.19 & (10) \\
\hline 12.8 & 1.0 & 165.9 & 26.24 & 1.90 & 77.16 & \\
\hline 8.4 & 0.8 & 113.7 & 23.36 & 1.85 & 73.86 & \\
\hline 13.0 & 1.6 & 66.6 & 12.98 & 0.52 & 195.31 & \\
\hline 12.2 & 0.4 & 72.8 & 15.50 & 0.92 & 167.50 & \\
\hline 12.1 & 1.3 & 89.8 & 17.10 & 1.23 & 134.77 & \\
\hline 11.4 & 1.0 & 83.6 & 25.62 & 0.85 & 136.43 & \\
\hline 14.7 & 1.0 & 249.6 & 33.32 & 2.51 & 58.89 & \\
\hline 8.5 & 1.3 & 71.1 & 17.51 & 0.79 & 119.47 & \\
\hline 15.4 & 1.2 & 107.0 & 16.74 & 0.64 & 143.88 & \\
\hline 11.3 & 1.6 & 95.7 & 19.08 & 1.15 & 118.06 & \\
\hline 10.1 & 1.8 & 69.4 & 21.42 & 0.91 & 145.56 & \\
\hline
\end{tabular}




$\begin{array}{llll}2000 & 16 & 1950 & \text { Isertia laevis } \\ 2000 & 16 & 1950 & \text { Ladenbergia acutifolia } \\ 2000 & 16 & 1950 & \text { Siparuna aspera } \\ 2000 & 16 & 1950 & \text { Cecropia andina }\end{array}$

$$
\begin{array}{rrrrrr}
13.4 & 2.1 & 63.7 & 15.96 & 0.78 & 210.53 \\
9.8 & 2.0 & 102.7 & 17.87 & 0.79 & 95.42 \\
11.4 & 1.7 & 119.9 & 29.09 & 1.51 & 95.06 \\
7.7 & 1.6 & 61.1 & 17.62 & 0.66 & 125.94
\end{array}
$$

$\begin{array}{llll}\text { Peru } & 1000 & 20.7 & 3087 \text { Ficus sanguinosa } \\ 1000 & 20.7 & 3087 \text { Virola cf. elongata. } \\ 1000 & 20.7 & 3087 \text { Pourouma minor } \\ 1000 & 20.7 & 3087 \text { Pouteria sp. } \\ 1500 & 18.8 & 2631 \text { Mollinedia simulans } \\ 1500 & 18.8 & 2631 \text { Guatteria sp. } \\ 1500 & 18.8 & 2631 \text { Tachigali cf setifera } \\ 1500 & 18.8 & 2631 \text { Miconia sp. } \\ 1855 & 18.0 & 2472 \text { Cyathea lechler } \\ 1855 & 18.0 & 2472 \text { Clethra revoluta } \\ 1855 & 18.0 & 2472 \text { Myrcia sp. }\end{array}$

$\begin{array}{llllll}-- & -- & -- & 18.20 & 1.30 & 131.00 \\ -- & -- & -- & 22.10 & 1.20 & 66.90 \\ -- & -- & -- & 22.20 & 1.10 & 80.40 \\ -- & -- & -- & 19.70 & 1.50 & 82.70 \\ -- & -- & -- & 24.00 & 1.30 & 83.70 \\ -- & -- & -- & 27.30 & 1.10 & 124.00 \\ -- & -- & -- & 27.30 & 1.30 & 75.20 \\ -- & -- & -- & 24.50 & 1.40 & 94.10 \\ -- & -- & -- & 18.70 & 0.80 & 123.00 \\ -- & -- & -- & 12.10 & 0.60 & 159.00 \\ -- & -- & -- & 15.30 & 0.70 & 103.00\end{array}$




\begin{tabular}{|c|c|c|c|}
\hline 1855 & 18.0 & 2472 & Hedyosmum racen \\
\hline 2350 & & & Clusia sp. \\
\hline 2350 & & & Prunus sp. \\
\hline 2350 & & & Hedyosmum scabr \\
\hline 2350 & & & Miconia sp. \\
\hline 1700 & 18.15 & & * \\
\hline 1445 & 18 & 3600 & Cecropia garciae \\
\hline 1445 & 18 & 3600 & Miconia sp. \\
\hline 1450 & 18 & 3600 & Psychotria race \\
\hline 1480 & 18 & 3600 & Clusia sp. \\
\hline 2160 & 11 & 7000 & Clusia pentandra \\
\hline 2160 & 11 & 7000 & Psychotria cuat \\
\hline 2145 & 11 & 7000 & Cecropia bullata \\
\hline 21 & 11 & 7000 & Miconia sp. \\
\hline
\end{tabular}

$\begin{array}{rrrrrr}-- & -- & -- & 18.20 & 1.00 & 97.10 \\ -- & -- & -- & 15.30 & 0.90 & 131.00 \\ -- & -- & -- & 20.90 & 1.10 & 105.00 \\ -- & -- & -- & 19.70 & 0.90 & 90.80 \\ -- & -- & -- & 24.30 & 1.10 & 115.00\end{array}$

Malaysia

Colombia

5.5

$64.0 \quad 14.00$

8.7

8.1

10.6

8.8

8.2

9.2

10.2

5.4 


$\begin{array}{lllll}\text { Venezuela } & 2400 & 13.6 & 2200 & \text { Clusia multiflora } \\ 2400 & 13.6 & 2200 & \text { Guettarda steyermarkii } \\ 2400 & 13.6 & 2200 & \text { Sapium stylare } \\ 2400 & 13.6 & 2200 & \text { Lycianthes ferruginea } \\ 2400 & 13.6 & 2200 & \text { Miconia resimoides }\end{array}$

$\begin{array}{llll}6.6-- & 200.2 & 11.10 & 304.30 \\ 6.3-- & 92.9 & 18.40 & 148.60 \\ 7.6-- & 41.4 & 31.40 & 54.20 \\ 4.5-- & 24.4 & 23.60 & 54.00 \\ 6.7-- & 46.8 & 36.90 & 69.70\end{array}$

$\begin{array}{llll}\begin{array}{l}\text { Upper montane } \\ \text { Ecuador }\end{array} & 3000 & 9 & 4500 \text { llex teratopis } \\ 3000 & 9 & 4500 \text { Hedyosmum purpurascens } \\ 3000 & 9 & 4500 \text { Clethra revoluta } \\ 3000 & 9 & 4500 \text { Clusia alata } \\ 3000 & 9 & 4500 \text { C. elliptica } \\ 3000 & 9 & 4500 \text { Weinmannia pubescens } \\ 3000 & 9 & 4500 \text { Persea ferruginea } \\ 3000 & 9 & 4500 \text { Miconia spec. }\end{array}$

$\begin{array}{rrrrrrr}2.6 & 0.2 & 8.0 & 9.17 & 0.25 & 325.66 & (10) \\ 7.5 & 1.0 & 54.0 & 15.82 & 0.53 & 138.89 & \\ 10.0 & 0.4 & 59.0 & 16.15 & 0.74 & 169.49 \\ 4.4 & 1.2 & 35.6 & 9.52 & 0.47 & 123.63 \\ 5.8 & 1.5 & 35.4 & 13.45 & 0.58 & 163.93 \\ 8.8 & 1.1 & 78.3 & 12.97 & 0.50 & 112.36 \\ 8.0 & 1.2 & 16.5 & 9.72 & 0.42 & 486.37 \\ 4.6 & 1.3 & 46.9 & 20.15 & 0.72 & 98.04\end{array}$




$\begin{array}{llll}3000 & 9 & 4500 & \text { Myrica pubescens } \\ 3000 & 9 & 4500 & \text { Styrax foveolaria }\end{array}$

$\begin{array}{llll}\text { Peru } & 2990 & 12.5 & 1706 \text { Clusia cretosa } \\ 2990 & 12.5 & 1706 \text { Weinmannia crassifolia } \\ 2990 & 12.5 & 1706 \text { Schefflera allocotantha } \\ 2990 & 12.5 & 1706 \text { Clethra cuneata } \\ 3600 & & \text { Polylepis pauta } . \\ 3600 & & \text { Gynoxis sp. } \\ 3600 & & \text { Budleja sp. } \\ 3600 & & \text { Pluchea }\end{array}$

Malaysia

$3400 \quad 8.8$

$3700 \quad 7.2$

$$
\begin{array}{llllll}
10.3 & 0.6 & 66.3 & 21.97 & 0.51 & 155.40 \\
10.2 & 0.9 & 33.5 & 10.00 & 0.40 & 304.46
\end{array}
$$

$\begin{array}{lllllll}-- & -- & -- & 12.30 & 1.10 & 127.00 & (6) \\ -- & -- & -- & 13.10 & 1.10 & 134.00 & \\ -- & -- & -- & 14.00 & 1.20 & 138.00 & \\ -- & -- & -- & 8.60 & 0.60 & 226.00 & \\ -- & -- & -- & 19.80 & 1.20 & 147.00 & \\ -- & -- & -- & 16.80 & 1.30 & 170.00 \\ -- & -- & -- & 13.80 & 0.90 & 220.00 \\ -- & -- & -- & 17.60 & 1.60 & 172.00\end{array}$

$\begin{array}{llllll}4.3-- & 32.0 & 16.00 & 160.70 & \text { (8) } \\ 3.1-- & 29.0 & 20.00 & 141.60 & \end{array}$


References: (1) (Reich and others (1999), (2) Santiago and others (2004); (3) Santiago and Wright (2007); (4) Eschenbach and others (1998); (5) Kenzo and others (2004); (6) van de Weg and others (2009); (7) Zhang and Cao (2009); (8) Hikosaka and other (2002); (9) Meir and others (2007); (10) this study; (11) Hölscher and others (2006); (12) Letts and Mulligan (2005); (13) Rada and others (2009). ( $\left.{ }^{\star}\right)$ Values are means over different species of a location. 


\section{Supplementary material of Chapter 3}

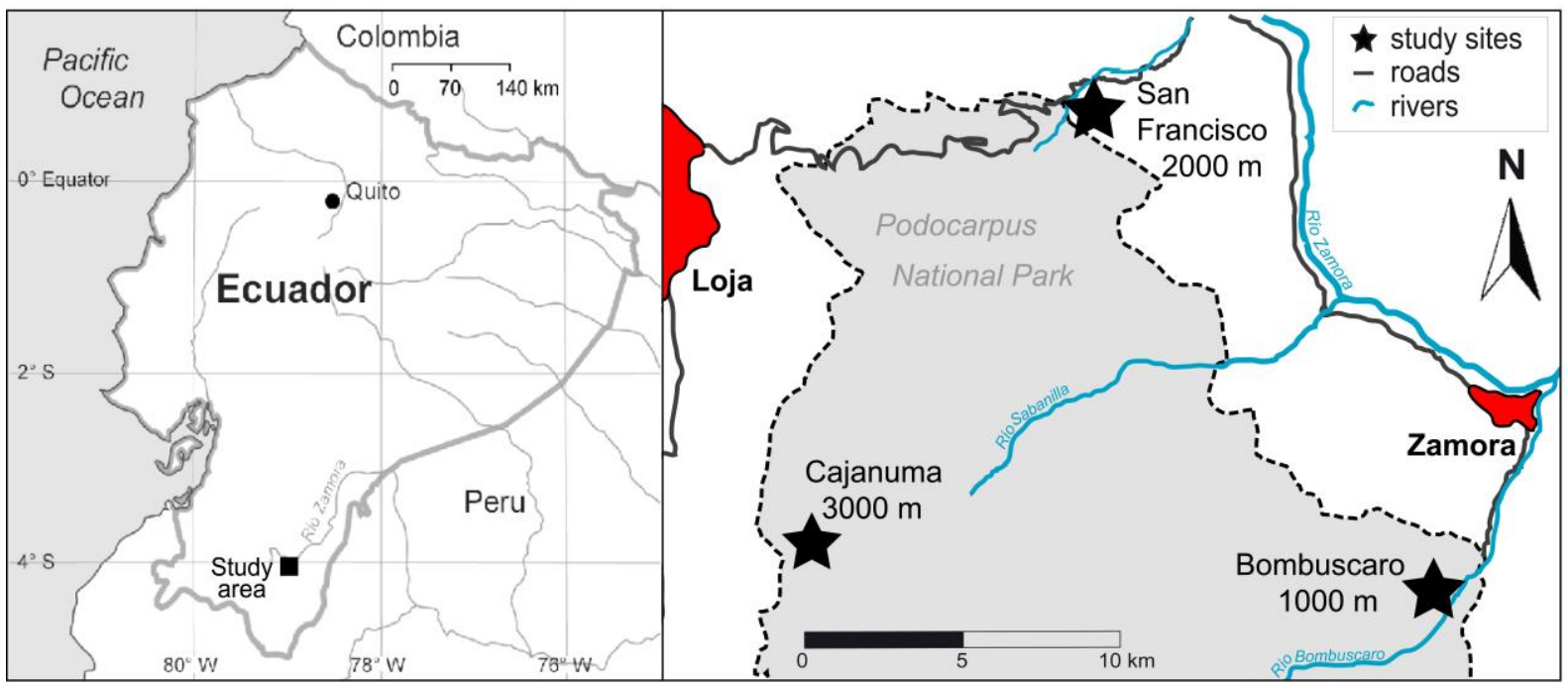

Figure A1. Location of the study area in southern Ecuador with the three stands at $1000 \mathrm{~m}$ (Bombuscaro), 2000 m (San Francisco Reserve) and 3000 m a.s.l (Cajanuma).

Table A1. Climatic characteristics of the stands at 1000, 2000 and $3000 \mathrm{~m}$ a.s.l. (after T. Peters, University of Erlangen, unpublished). Rainfall, mean annual air temperature and relative air humidity according to measurements in gaps close to the three forest sites (2year means, 2008-2009). $\left[\mathrm{CO}_{2}\right]$ is the $\mathrm{CO}_{2}$ concentration of the air above the boundary layer as estimated from air pressure and by assuming a constant mixing ratio of $370 \mu \mathrm{mol} \mathrm{CO}_{2} \mathrm{~mol}$ air $^{-1}$ along the slope (after Wittich et al. 2012).

\begin{tabular}{ccccc}
\hline $\begin{array}{c}\text { Elevation } \\
m \text { asl }\end{array}$ & $\begin{array}{c}\text { Rainfall } \\
m m y r^{-1}\end{array}$ & $\begin{array}{c}\text { Air } \\
\text { temperature } \\
{ }^{\circ} \mathrm{C}\end{array}$ & $\begin{array}{c}\text { Air } \\
\text { humidity } \\
\%\end{array}$ & $\begin{array}{c}{\left[\mathrm{CO}_{2}\right]} \\
\mathrm{Pa}\end{array}$ \\
\hline 2960 & C. 2580 & 7 & 97 & 27 \\
1950 & C. 1790 & 13 & 86 & 30 \\
1000 & C. 2200 & 20 & 92 & 33 \\
\hline
\end{tabular}


Table A2. Chemical characteristics of the organic layer and upper mineral soil in the three stands at 1000, 2000 and $3000 \mathrm{~m}$ (after Wolf 2010 and Wittich et al. 2012). Means \pm SE of soil profiles dug in six plots at mid-slope position in the stands at a maximum distance to the studied trees of $500 \mathrm{~m} . \mathrm{P}_{\mathrm{av}}$ - available $\mathrm{P}$ was determined by combining a modified Hedley fractionation with an extraction by anion exchange resins and $\mathrm{NaHCO}_{3}$ percolation. $\mathrm{N}$ mineralization and nitrification rates were measured by the in situ buried bag method. Different small letters indicate significant differences between elevations $(P<0.05)$.

\begin{tabular}{|c|c|c|c|c|c|c|c|}
\hline Elevation & $m$ asl & $1000 \mathrm{~m}$ & & $2000 \mathrm{~m}$ & & $3000 \mathrm{~m}$ & \\
\hline \multicolumn{8}{|c|}{ Organic layer } \\
\hline $\mathrm{pH}\left(\mathrm{H}_{2} \mathrm{O}\right)$ & & $4.3 \pm 0.6$ & $\mathbf{a}$ & $4.8 \pm 0.5$ & $\mathbf{a}$ & $3.7 \pm 0.1$ & \\
\hline $\mathrm{C} / \mathrm{N}$ & & $19.0 \pm 2.5$ & $a b$ & $15.6 \pm 0.6$ & $\mathbf{a}$ & $23.9 \pm 1.4$ & b \\
\hline$P_{\text {tot }}$ & $k g h a^{-1}$ & $46.8 \pm 17.3$ & & $70.3 \pm 26.5$ & & $15.1 \pm 1.4$ & \\
\hline $\mathrm{P}_{\mathrm{av}}$ & $k g h a^{-1}$ & $11.8 \pm 5.3$ & $\mathbf{a}$ & $12.5 \pm 4.9$ & $\mathbf{a}$ & $5.1 \pm 0.6$ & $\mathbf{a}$ \\
\hline
\end{tabular}

\section{Mineral soil}

$\mathrm{pH}\left(\mathrm{H}_{2} \mathrm{O}\right)(\mathrm{Ah})$

$\mathrm{C} / \mathrm{N}(\mathrm{Ah})$

$\begin{array}{ccccc}4.3 \pm 0.3 & \text { ab } & 4.7 \pm 0.4 & \text { a } & 3.7 \pm 0.1 \\ 15.6 \pm 0.1 & \text { a } & 14.1 \pm 1.5 & \text { a } & 18.0 \pm 1.1 \\ 123.8 \pm 9.7 & & 241.3 \pm 47.7 & & 62.6 \pm 12.6 \\ 12.4 \pm 0.7 & \text { a } & 34.6 \pm 7.1 & \text { b } & 14.9 \pm 3.0\end{array}$

$P_{\text {tot }}(0-10 \mathrm{~cm})$

$\mathrm{kg} \mathrm{ha}^{-1}$

$\mathrm{P}_{\mathrm{av}}(0-10 \mathrm{~cm})$

$\mathrm{kg} \mathrm{ha}^{-1}$

$12.4 \pm 0.7 \quad$ a $\quad 34.6 \pm 7.1$

b $-14.9 \pm 3.0$

Topsoil $\quad(0-5 \mathrm{~cm})$

\begin{tabular}{|c|c|c|c|c|c|c|}
\hline Extractable $\mathrm{NH}_{4}^{+}$ & $\mathrm{kgN} h \mathrm{a}^{-1} 10 d^{-1}$ & $2.7 \pm 0.3$ & $\mathbf{a}$ & $0.9 \pm 0.3$ & b & $0.7 \pm 0.1$ \\
\hline Extractable $\mathrm{NO}_{3}^{-}$ & $\mathrm{kgN} h \mathrm{a}^{-1} 10 d^{-1}$ & $0.5 \pm 0.2$ & a & $0.3 \pm 0.1$ & a & $0.02 \pm 0.01$ \\
\hline Net $\mathrm{N}$ mineralization & $\mathrm{kgN} h \mathrm{a}^{-1} 10 \mathrm{~d}^{-1}$ & $4.0 \pm 1.6$ & a & $1.4 \pm 0.7$ & $a b$ & $0.6 \pm 0.4$ \\
\hline Net nitrification & $\mathrm{kgN} h \mathrm{a}^{-1} 10 d^{-1}$ & $1.3 \pm 2.7$ & ab & $1.8 \pm 0.6$ & a & $0.04 \pm 0.04$ \\
\hline
\end{tabular}


Table A3. Stand structural characteristics of the three stands at 1000,2000 and $3000 \mathrm{~m}$ (after Wittich et al. 2012 and Homeier et al., unpublished; LAl, leaf life span, BGB and leaf biomass: Moser et al. 2007, 2011). Abbreviations: AGB, aboveground biomass; BGB, belowground biomass (coarse and fine roots); $\mathrm{DBH}$, diameter in breast height; LAl, leaf area index. Given are means \pm SE for each elevation. Means of tree $\mathrm{DBH}$, stem density, basal area and AGB were calculated for 9-18 permanent plots (400 $\mathrm{m}^{2}$ each) covering the whole range of topographic positions at the respective elevations (trees $>10 \mathrm{~cm} \mathrm{dbh).} \mathrm{Estimates} \mathrm{for}$ nutrient pools in canopy leaf biomass were calculated from leaf biomass data (Moser et al. 2007) and mean foliar $N$ and $P$ concentrations according to Homeier et al. (unpublished). Different small letters indicate significant differences between elevations $(P<0.05)$.

\begin{tabular}{|c|c|c|c|c|c|c|c|}
\hline Elevation & $m$ asl & 1000 & & 2000 & & 3000 & \\
\hline Canopy height & $m$ & $25-30$ & & $16-20$ & & $8-10$ & \\
\hline DBH & $\mathrm{cm}$ & $19 \pm 1$ & $\mathbf{a}$ & $20 \pm 1$ & $\mathbf{a}$ & $18 \pm 1$ & $\mathbf{a}$ \\
\hline Stem density & $n h a^{-1}$ & $822 \pm 50$ & $\mathbf{a}$ & $900 \pm 62$ & $\mathbf{a}$ & $1061 \pm 84$ & $\mathbf{a}$ \\
\hline Basal area & $m^{2} h a^{-1}$ & $29 \pm 4$ & $\mathbf{a}$ & $34 \pm 3$ & $\mathbf{a}$ & $30 \pm 3$ & $\mathbf{a}$ \\
\hline AGB & $M g h a^{-1}$ & $177 \pm 28$ & $\mathbf{a}$ & $158 \pm 22$ & a & $89 \pm 10$ & b \\
\hline BGB & $M g h a^{-1}$ & 32.1 & & 26.1 & & 62.8 & \\
\hline LAI & $m^{2} m^{-2}$ & $6 \pm 0.4$ & $\mathbf{a}$ & $5.7 \pm 0.5$ & $\mathbf{a}$ & $2.2 \pm 0.2$ & b \\
\hline Leaf life span & months & $16 \pm 2.6$ & $\mathbf{a}$ & $24 \pm 2.3$ & b & $25 \pm 2.3$ & b \\
\hline Leaf biomass & $M g h a^{-1}$ & 6.8 & $\mathbf{a}$ & 9.7 & b & 3.6 & c \\
\hline Leaf biomass $\mathrm{N}$ pool & $\mathrm{kg} \mathrm{ha}^{-1}$ & 123 & & 202 & & 46 & \\
\hline Leaf biomass $\mathrm{P}$ pool & $\mathrm{kg} \mathrm{ha}^{-1}$ & 3.8 & & 7.9 & & 1.6 & \\
\hline
\end{tabular}




\section{Supplementary material of Chapter 4}

Table 5. Slope $b, R^{2}$, adjusted $R^{2}$ and $p$ value of the regression of ${ }^{13} C_{\text {excess }}$ values (in $\mu \mathrm{mol} g$ ${ }^{1}$ ) on the corresponding ${ }^{15} \mathrm{~N}_{\text {excess }}$ values (in $\mu \mathrm{mol} \mathrm{g}{ }^{-1}$ ) in different organs of the six tree species $5 \mathrm{~d}$ after the application of dual-labelled glycine. A slope of 2.0 would indicate $100 \%$ uptake of glycine-derived $\mathrm{N}$ in form of intact molecules. Note that the slope is always much smaller than 2 but none of the regressions are significant at $p<0.05$.

\begin{tabular}{|c|c|c|c|c|c|c|}
\hline & & $\mathrm{b}$ & $\mathrm{R}^{2}$ & $\mathrm{R}^{2}$ adj. & $p$ & $\mathrm{n}$ \\
\hline \multicolumn{7}{|l|}{$1000 \mathrm{~m}$ asl } \\
\hline \multirow[t]{4}{*}{ Pouteria torta } & Fine roots & 0.12 & 0.51 & 0.02 & 0.25 & 3 \\
\hline & Coarse roots & 0.31 & 0.90 & 0.79 & 0.11 & 3 \\
\hline & Shoot & -1.83 & 0.97 & 0.93 & 0.06 & 3 \\
\hline & Leaves & -0.48 & 0.01 & -0.97 & 0.46 & 3 \\
\hline \multirow[t]{4}{*}{ Hedyosmum sprucei } & Fine roots & 0.03 & 0.28 & 0.04 & 0.18 & 5 \\
\hline & Coarse roots & 0.16 & 0.01 & -0.32 & 0.44 & 5 \\
\hline & Shoot & 0.01 & 0.07 & -0.24 & 0.33 & 5 \\
\hline & Leaves & 0.03 & 0.64 & 0.52 & 0.05 & 5 \\
\hline \multicolumn{7}{|l|}{2000 m asl } \\
\hline \multirow[t]{3}{*}{ Myrciasp. nov } & $\begin{array}{l}\text { Fine roots } \\
\text { Coarse roots }\end{array}$ & 0.24 & 0.12 & -0.33 & 0.33 & 4 \\
\hline & Shoot & -0.32 & 0.16 & -0.26 & 0.30 & 4 \\
\hline & Leaves & -0.02 & 0.01 & -0.49 & 0.46 & 4 \\
\hline \multirow[t]{4}{*}{ Hedyosmum trans/ucidum } & Fine roots & 0.42 & 0.53 & 0.30 & 0.13 & 4 \\
\hline & Coarse roots & 0.57 & 0.79 & 0.69 & 0.05 & 4 \\
\hline & Shoot & 0.00 & 0.00 & -0.50 & 0.49 & 4 \\
\hline & Leaves & 0.08 & 0.04 & -0.44 & 0.40 & 4 \\
\hline \multicolumn{7}{|l|}{3000 m asl } \\
\hline \multirow[t]{4}{*}{ Graffenrieda harlingii } & Fine roots & -0.36 & 0.22 & -0.04 & 0.22 & 5 \\
\hline & Coarse roots & -0.01 & 0.00 & -0.33 & 0.49 & 5 \\
\hline & Shoot & -0.03 & 0.29 & 0.05 & 0.17 & 5 \\
\hline & Leaves & 0.01 & 0.03 & -0.29 & 0.38 & 5 \\
\hline \multirow[t]{3}{*}{ Hedyosmum cf. purpurascens } & $\begin{array}{l}\text { Fine roots } \\
\text { Coarse roots }\end{array}$ & 0.13 & 0.97 & 0.93 & 0.06 & $\begin{array}{c}3 \\
(2)\end{array}$ \\
\hline & Shoot & -0.14 & 0.16 & -0.27 & 0.30 & 4 \\
\hline & Leaves & 0.08 & 0.61 & 0.41 & 0.11 & 4 \\
\hline
\end{tabular}




\section{Acknowledgements}

Many people helped and supported me in the process of realizing my thesis. I wish to thank

- Christoph Leuschner for providing me with the research topic and the supportive guidance throughout the completion of the thesis

Dirk Hölscher for taking over the co-evaluation

$\checkmark$ Jürgen Homeier for supporting me throughout the thesis in the coordination of the field work, the transport and the analysis of the samples and for valuable suggestions during field work and manuscript writing

- Viviana Horna for introducing me to the difficulties of gas exchange measurements on the steep slopes of the research area and for valuable suggestions during manuscript writing

- My collegues in Loja for their help and support in coordination and field work, especially Nohemy Poma for looking after my projects during my times in Germany

$\checkmark$ Paul Gonzales and Linda Rohnstock for field assistance

- Felix Matt and Jörg Zeilinger for coordination at the ECSF

- Heinz Coners for rapid solutions on every technical problem

$\checkmark$ Stefan Fleck and Nicole Legner for sharing their expertise on $\mathrm{A} / \mathrm{Ci}$-curves

- Den TAs der Pflanzenökologie der Universität Göttingen für die Hilfe bei der Probenbearbeitung

- Meiner Familie für ihre Unterstützung während der gesamten Zeit 


\section{Curriculum Vitae}

Personal Information

Name

Bärbel Wittich

Date of birth

17 August 1980

Place of birth

Ulm

Education and research experience

2008-2013

PhD study at the Department of Plant Ecology, University of Göttingen, Germany

2001-2007

Study of biology at the University of Göttingen, Germany

Degree obtained: Diplom-Biologin

Thesis title: Einfluss von experimentell

manipulierter Luftfeuchte und Strahlung auf

Wachstum und Morphologie von

Waldbodenpflanzen

1987-1999

Freie Waldorfschule Ulm, Germany High School graduation: Allgemeine Hochschulreife 